\title{
Griezelig gewoon : gotieke verschijningen in Nederlandse romans, 1980-1995
}

Citation for published version (APA):

Andeweg, A. (2010). Griezelig gewoon : gotieke verschijningen in Nederlandse romans, 1980-1995.

[Doctoral Thesis, Maastricht University]. Maastricht University. https://doi.org/10.26481/dis.20100401aa

Document status and date:

Published: 01/01/2010

DOI:

10.26481/dis.20100401aa

Document Version:

Publisher's PDF, also known as Version of record

\section{Please check the document version of this publication:}

- A submitted manuscript is the version of the article upon submission and before peer-review. There can be important differences between the submitted version and the official published version of record.

People interested in the research are advised to contact the author for the final version of the publication, or visit the DOI to the publisher's website.

- The final author version and the galley proof are versions of the publication after peer review.

- The final published version features the final layout of the paper including the volume, issue and page numbers.

Link to publication

\footnotetext{
General rights rights.

- You may freely distribute the URL identifying the publication in the public portal. please follow below link for the End User Agreement:

www.umlib.nl/taverne-license

Take down policy

If you believe that this document breaches copyright please contact us at:

repository@maastrichtuniversity.nl

providing details and we will investigate your claim.
}

Copyright and moral rights for the publications made accessible in the public portal are retained by the authors and/or other copyright owners and it is a condition of accessing publications that users recognise and abide by the legal requirements associated with these

- Users may download and print one copy of any publication from the public portal for the purpose of private study or research.

- You may not further distribute the material or use it for any profit-making activity or commercial gain

If the publication is distributed under the terms of Article $25 \mathrm{fa}$ of the Dutch Copyright Act, indicated by the "Taverne" license above, 
GRIEZELIG GEWOON 



\section{GRIEZELIG GEWOON}

Gotieke verschijningen in Nederlandse romans, 1980-1995

\section{PROEFSCHRIFT}

ter verkrijging van de graad van doctor aan de Universiteit Maastricht, op gezag van de Rector Magnificus, Prof. mr. G.P.M.F. Mols volgens het besluit van het College van Decanen, in het openbaar te verdedigen op donderdag 1 april 2010 om 16.00 uur

door

Agnes Andeweg 


\section{PROMOTOR}

Prof. dr. M.J.H. Meijer

COPROMOTOR

Dr. E. Wesseling

\section{BEOORDELINGSCOMMISSIE}

Prof. dr. J.H.W. Kusters (voorzitter)

Prof. dr. G. Buelens, Universiteit Utrecht

Prof. dr. R.L. Buikema, Universiteit Utrecht

Prof. dr. A. Labrie

Dr. J.H. de Roder 


\section{INHOUDSOPGAVE}

Dankwoord 3

1 INLEIDING: HET GOTIEKE LEZEN 5

Cultureel werk van het gotieke 7

Van genre naar strategie 13

Over Goten en Britten 16

De breuk tussen traditie en moderniteit 19

Nederland en het gotieke 22

De bestudering van het gotieke, gender en queer $\quad 27$

De opzet van dit boek 30

2 HET SPOOK VAN DE HOMOSEKSUALITEIT.

LETTER EN GEEST VAN FRANS KELLENDONK 35

Eerdere interpretaties 39

Spoken zien 44

Vrijgezellen 48

Gotieke perversie $\quad 56$

Ons kent ons $\quad 58$

3 BEZITTEN EN BEZETEN WORDEN.

DE VIERDE MAN VAN GERARD REVE 67

De wederopstanding van de femme fatale 73

Het gotieke en het komische 77

Parodie van een heterobestaan 80

Echt en onecht: Herman 87

Door Maria tot Jezus 91

Seksualiteit en schrijverschap 94

Een verhaal moet niet te vroeg klaarkomen $\quad 98$ 
4 BIJ HOOG EN BIJ LAAG.

VRIEND VAN VERDIENSTE VAN THOMAS ROSENBOOM 103

Een historische roman 108

Vriendschap verdienen: over de grenzen van klasse $\quad 110$

Klassenverschil en gender $\quad 114$

Zuiverheid en het abjecte $\quad 117$

Jongens onder elkaar 123

Mannelijk masochisme 129

Moeders en zonen 133

Het anachronisme van de seksuele onschuld $\quad 136$

5 DE GOTIEKE STEMMEN VAN RENATE DORRESTEIN.

NOORDERZON EN HET PERPETUUM MOBILE VAN DE LIEFDE 139

Feminisme en het gotieke volgens Nancy Armstrong 142

Noorderzon en female gothic 146

De stem van een vrouw $\quad 152$

Het Boze Oog 157

Gotieke stemmen in Het perpetuum mobile van de liefde 172

Vampiristisch zusterschap 179

6 HET VERLANGEN NAAR VERLANGEN.

SPOOKLIEFDE VAN VONNE VAN DER MEER 181

Ierland als gotieke setting 183

Vrouw met houten onderlijf 189

Seks tot (w)elke prijs 195

De kracht van de herhaling 193

7 'SeEING THINGS'. SlotbeschouWING 209

Bibliografie 219

Summary 239

Namenregister $\quad 245$

Curriculum Vitae 252 


\section{DANKWOORD}

Dankzij de praktische en intellectuele hulp van velen was het schrijven van dit boek tot op het laatst een plezierige onderneming. Om te beginnen wil ik Rosemarie Buikema bedanken, die mij op het spoor zette van het gotieke in de Nederlandse literatuur. Dankzij het Centrum voor Gender en Diversiteit van de Universiteit Maastricht kwam er geld voor een onderzoeksplaats om die ideeën uit te voeren. Mijn promotor Maaike Meijer en mijn co-promotor Lies Wesseling dank ik voor het immer grote vertrouwen dat ik van hen kreeg. Maaike, ik prijs mij gelukkig dat ik al zo lang met je samenwerk. Van jouw lust tot lezen en je grote optimisme heb ik ontzettend veel geleerd. Lies, jouw praktische betrokkenheid en onderkoelde humor maakten het werken met jou tot een groot genoegen. Je inhoudelijke deskundigheid over het gotieke strekte zich zelfs uit tot de truitjes die Morticia Addams breit.

Dank aan alle voormalige en huidige collega's van het Centrum voor Gender en Diversiteit, die regelmatig mijn stukken becommentarieerden, tips gaven, praktische ondersteuning boden en het Centrum tot zo'n leuke werkplek maakten: Ineke Boerefijn, Mineke Bosch, Louis van den Hengel, Annelies van der Horst, Marli Huijer, Ruth de Kanter, Ineke Klinge, Christine Lausberg, Wilma Lieben, Roel van den Oever, Aagje Swinnen, Akke Visser en Josje Weusten. Dank aan de collega's van de vakgroep Letteren en Kunst, waar het Centrum sinds 2009 aansluiting vond. Ik wil met name Wiel Kusters en Jan de Roder noemen, die uitgebreid commentaar gaven op afzonderlijke hoofdstukken. Bij het onderzoekscolloquium MARKS van de Faculteit Cultuur- en Maatschappijwetenschappen van de UM, de Onderzoekschool Literatuurwetenschap en de Nederlandse Onderzoekschool Vrouwenstudies kreeg ik de gelegenheid om stukken te presenteren. De studenten Gothic Fictions van het University College Maastricht stelden mij in staat jaar na jaar mijn gedachten over de gothic aan te scherpen.

Velen lazen een of meerdere stukken in wording, of dachten anderszins mee. Het aioclubje, bestaande uit Ingrid Glorie, Marijke Huisman, Kathrin Lang en Roel van den Oever, gaf altijd het meest gedetailleerde commentaar en was daarnaast een bron van steun en gezelligheid. Annemie Halsema paarde kennis van Butler aan liefde voor Reve, wat haar tot de ideale commentator van het Reve-hoofdstuk maakte. Jo Radersma en Ben Peperkamp gaven stimulerend commentaar op artikelen, en Dominique Niesten op het hoofdstuk over Kel- 
lendonk. Leon van Schoonneveldt attendeerde mij op Letter en Geest. Theo van der Meer, Inger Leemans, Erica van Boven, Toos Streng en Geertje Mak losten in de allerlaatste fase voetnoten op. Marion Wiendels hielp door voortvarend het register aan te vatten.

Ik dank Marian van der Klein, die weet wat het is om een proefschrift te schrijven maar met wie ik gelukkig nog veel meer deel. Tussen de bedrijven door redigeerde mijn liefste alle hoofdstukken en gaf mij daarmee het laatste zetje naar de eindstreep. De komst van Fenna, en daarna Ido, was een groot geluk. Ze maakten het leven drukker, maar het proefschrift eenvoudiger. Zonder Mineke Bosch en Jo Radersma was de combinatie van moederschap in Utrecht en wetenschap in Maastricht ingewikkelder geweest. Zij boden mij in Bemelen jarenlang onderdak als mad woman in the attic, en Jo paste bovendien een tijdje een dag op baby Fenna.

Dank ten slotte aan mijn ouders, Edgar Andeweg en Janny AndewegHolland. Ze konden het proefschrift wel af kijken, maar bleven volhardend wachten en lazen uiteindelijk alles. Mijn moeder bracht mij de liefde voor het lezen bij en stond daarmee aan de basis van dit proefschrift. Aan haar draag ik dit boek op.

Utrecht, 6 december 2009 


\section{1}

\section{INLEIDING: HET GOTIEKE LEZEN}

'The Gothic cannot be an essence, for what is Gothicized constantly changes' (Mighall 1999, 286).

'Reading Gothic makes us see things' (Brewster 2000, 281).

Als schrijver Willem Brakman (1922-2008) in de jaren zeventig de beroemde film Frankenstein (1931) bekijkt, valt hem dat niet mee: 'Zonder horror, zonder terror balanceerde ik op de rand van de verveling' (Brakman 1976, 105). Maar achteraf, in zijn herinnering, krijgt de film alsnog iets beklemmends. De beelden van acteur Boris Karloff als het monster komen hem opnieuw voor de geest en hij herinnert zich hoe hij de film als kind voor het eerst zag in de jaren dertig. Toen ging hij Frankenstein zien met een vriend, Ton Bijte, die later, in de Tweede Wereldoorlog, werd doodgeschoten door Duitse soldaten. Brakman herinnert zich hoe hij na afloop naar huis ging, noodgedwongen wandelend omdat zijn fiets gestolen bleek te zijn - 'een onbegrijpelijke, niet te vullen leegte' (106), en hoe hij later nog wel eens naar de plek ging bij het spoor waar zijn vriend was doodgeschoten - 'ook een onbegrijpelijke, niet te vullen leegte' (106).

Frankenstein, gebaseerd op Mary Shelleys klassieke griezelroman uit 1818, stuurt Brakmans herinnering aan zijn vriend. Allereerst is de film de aanjager van de herinnering: het weerzien doet hem terugdenken aan de eerste keer dat hij de film zag. Maar ook inhoudelijk structureert Frankenstein Brakmans herinnering. Net zoals het monster ongevraagd tot leven wordt geroepen door dokter Victor Frankenstein, verschijnt Ton Bijte veertig jaar na dato weer even levend voor Brakmans geestesoog, 'of hij wilde of niet, in de sneeuw en op de fiets' (106). Hun gelijkenis ligt in die status van creatuur. In Brakmans herinnering versmelt het gezicht van zijn vriend dan ook met het monster: 'zijn gelaat $[$ nam] de trekken aan $[\ldots]$ van Boris, die $[\ldots]$ voor zich uitstaarde, met hangen- 
de armen, het zware hoofd wat scheef en opzij gezakt, even melancholiek als doodmoe van het geschapen zijn' (107).

Een andere Frankenstein-echo in Brakmans anekdote is het veelbetekenende detail dat hij de film destijds bekeek door een kaartje met een gat erin, omdat hij bijziend was en te ijdel om een bril te dragen. Het monster van Frankenstein leert praten en lezen door een gezin stiekem te bestuderen, door een spleet in de muur. Impliciet positioneert Brakman zich hier als het monster, dat door een gat te kijken kennismaakt met de menselijke beschaving. Anders dan het monster ziet hij geen ideale gemeenschap waar hij bij wil horen, maar iets beangstigends. ${ }^{1}$ Voor Brakman lag de angst die het monster destijds wèl bij hem opriep in de onvoorspelbaarheid van diens handelen. Het monster 'balanceert op de rand van alle gruwelijke mogelijkheden' (165) en belichaamt daarmee voor Brakman de angst van de tijd: 'de in de dertiger jaren voelbaar opgetaste agressie en het stil en scherp luisterend wachten op de vorm die dat zou gaan aannemen.' (165). De volwassen Brakman duidt met terugwerkende kracht wat hij als jongen door het gat zag: een voorafschaduwing van komende gruwelen van de Tweede Wereldoorlog: 'Ja de terror kwam uit Duitsland, zonder film en fiets zou ik het misschien weer vergeten zijn en was Ton Bijte nog eenzamer neergelegd daar bij dat station.' (166).

In het kader van dit boek is Brakmans essay interessant omdat hij zich als een van de weinige Nederlandse auteurs in beschouwende zin met de gotieke roman heeft beziggehouden. Het weerzien van Frankenstein is voor Brakman aanleiding om Shelleys roman te herlezen en een essay te wijden aan de Engelstalige gothic novel uit de periode 1765-1820. Interessanter nog vind ik hoe Brakmans herinnering wordt gestructureerd door elementen uit de gothic novel, op de manier zoals ik hierboven beschreef. Wat hem overkomt bij het kijken naar de film lijkt op wat in veel gothic novels gebeurt: iets uit het verleden keert terug in het heden. In gotieke romans is dat vaak een spook, maar in dit geval wordt die positie ingenomen door de film, of eigenlijk door de herinnering aan het kijken naar de film. Brakman brengt daarmee meteen op voor hem kenmerkende wijze allerlei verdubbelingen aan, wat op zichzelf weer een mechanisme is dat vaak in gothic novels te vinden is.

\footnotetext{
${ }^{1}$ Brakmans essay, Over het monster van Frankenstein (1976), is als tweeluik uitgegeven met de novelle Glubkes oordeel. Ook in die apocalyptische novelle komt het gotieke motief voor van het kijken door een gat, waarachter iets gruwelijks te zien is - zoals de jonge Brakman naar het monster in de film keek. Glubkes naam betekent zoveel als 'gat' (zie Van Alphen (1988), p. 52). Ook de gruwelen die in Glubkes oordeel achter het gat plaatsvinden zijn een duidelijke verwijzing naar de Tweede Wereldoorlog.
} 
In zijn essay interpreteert Brakman het gotieke monster van Frankenstein in het licht van de historische context waarin hij de film voor het eerst zag. Het monster verbeeldt voor hem de 'voelbaar opgetaste agressie' van de jaren dertig. Het literaire/filmische motief en de historische context vermengen zich zelfs, als Brakman schrijft dat zijn vriend 'onverhoeds de film [werd] binnengetrokken en het [uit] was [...] met de pret' (165). Met deze formulering maakt Brakman de dood van zijn vriend tot een onderdeel van de film, waarmee hij het onderscheid tussen fictie en werkelijkheid tijdelijk opheft. Datzelfde gebeurt in zijn herinnering, als beelden van het monster zich vermengen met beelden van zijn vriend.

Het voorbeeld van Brakman bevat in een notendop de belangrijkste thema's van mijn onderzoek. In dit boek analyseer ik verschijningen van het gotieke in laattwintigste-eeuwse Nederlandse literatuur. Ik kies daarvoor zes romans: Letter en Geest. Een spookverhaal (1982) van Frans Kellendonk, De vierde man (1981) van Gerard Reve, Vriend van verdienste (1985) van Thomas Rosenboom, Noorderzon (1986) en Het perpetuum mobile van de liefde (1988) van Renate Dorrestein en de novelle Spookliefde (1995) van Vonne van der Meer. Deze boeken behoren geen van alle tot het klassieke griezelgenre à la Bram Stoker of Stephen King. In Nederland bestaat niet zo'n traditie, zoals al eerder is opgemerkt (Schouten 1997, Buikema \& Wesseling 2006). Maar in elk van deze romans maakt het gotieke wel degelijk zijn entree: met een geheim kamertje op zolder, een spookverschijning in de bibliotheek, kraaien op de begraafplaats, corrupte monniken op een eiland of een metamorfose tot vampier.

\section{CULTUREEL WERK VAN HET GOTIEKE}

Het gaat mij bij de close readings van de romans van Kellendonk, Reve, Rosenboom, Dorrestein en Van der Meer niet zozeer om de vraag wat het gotieke is in een hedendaagse context, maar wat het doet. Dit boek is dus geen begripsgeschiedenis van het gotieke, al besteed ik in deze inleiding wel enige aandacht aan de historische betekenissen van het begrip.

De belangrijkste vraag die ik in dit boek wil beantwoorden is: wat doet het gotieke in deze selectie van laattwintigste-eeuws Nederlands proza? Dat is in de eerste plaats een vraag naar de verschijningen van het gotieke binnen de tekst: wat voor gotieke elementen zijn er an te wijzen en hoe sorteren die literair effect? In de tweede plaats is het een vraag naar de manier waarop dat verschijnen van gotieke elementen aan het eind van de twintigste eeuw geduid kan 
worden. Het is een vraag naar het zogeheten culturele werk dat die romans verrichten.

Deze benadering ontleen ik aan het werk van de literatuurwetenschapper Jane Tompkins (1985), die in dit verband de term cultural work bezigt. Met cultural work doelt Tompkins op het fenomeen dat in literatuur - 'hoge' en 'lage' literatuur - maatschappelijke spanningen verwerkt en herwerkt worden. Culturele artefacten, zoals romans, zijn niet alleen een weerspiegeling van de cultuur waarin zij ontstaan, maar vormen een plek waar maatschappelijke normen en waarden worden ondermijnd, bevestigd, of gecreëerd. In Tompkins' woorden:

[T] he novel functions both as a means of describing the social world and as a means of changing it. It not only offers an interpretive framework for understanding the culture, and, through the reinforcement of a particular code of values, recommends a strategy for dealing with cultural conflict, but it is itself an agent of that strategy, putting into practice the measures it prescribes. (Tompkins, 1985, 135)

De manier waarop Tompkins literatuur beschouwt staat bekend als New Historicism, een benadering die in de jaren tachtig ontstond en zich kenmerkt door het interpreteren van literatuur als onderdeel van een maatschappelijk krachtenveld. Literatuur is in die opvatting een actor in de culturele en maatschappelijke verhoudingen; anders dan in het formalistische New Criticism, waarin het literaire werk vooral een autonoom en universeel kunstwerk is, en anders dan in het marxistische (Old) Historicism, waar literatuur slechts de bestaande machtsverhoudingen representeert en er zelf geen actieve factor in is. Tompkins vraagt in haar analyses van literatuur aandacht voor de verwerking en herwerking van 'cultural conflicts'. Zij brengt dus, door middel van tekstanalyses, literatuur in verband met een bredere maatschappelijke context: met de maatschappij waarin die literatuur geschreven en gelezen wordt, of met de samenleving waar zij over schrijft.

Ook in Nederland is het verband tussen literatuur en maatschappij aan de orde gesteld, zij het zelden vanuit het perspectief van New Historicism. ${ }^{2}$ Vanaf begin jaren tachtig, de periode waarin mijn selectie start, werd de plaats van literatuur in de Nederlandse samenleving opnieuw een thema in het openbare

\footnotetext{
${ }^{2}$ Zie voor Nederlandse toepassingen van New Historicism Pieters (2005, 2005a), Buikema \& Wesseling (2006). Zie Kemperink en Vermeer (2008) voor een overzicht van benaderingen waarin tekst en context met elkaar in verband worden gebracht.
} 
debat over literatuur en literatuurbeschouwing. ${ }^{3}$ Als oproep tot straatrumoer, als ideologiekritiek, en als verkooptruc is de relatie tussen literatuur en maatschappij bepleit, bezongen, geanalyseerd en verguisd. Vanuit uiteenlopende standpunten hebben neerlandici als Ernst van Alphen, Maaike Meijer, Frans Ruiter, Wilbert Smulders en Thomas Vaessens zich sterk gemaakt voor een naar plaats en tijd (meer) gesitueerde literatuurbeschouwing. Van Alphen en Meijer (1991) introduceerden de ideologiekritiek in de neerlandistiek, Ruiter en Smulders (1996) plaatsten vanuit een meer cultuurhistorische invalshoek de 'lotgevallen van de Nederlandse literatuur' tussen 1840 en 1990 tegen de achtergrond van culturele, sociale en politieke veranderingen. Vaessens stelde recentelijk nog dat literatuurbeschouwing in Nederland meer aandacht zou moeten hebben voor de banden tussen literatuur en maatschappelijk engagement (Vaessens 2009). Bij het pleidooi van deze auteurs sluit ik me in dit boek graag aan.

Ik zal met behulp van een gotiek interpretatiekader het verband tussen literatuur en maatschappelijke context opnieuw doordenken, aan de hand van de romans die ik centraal stel. Die romans verschenen in de jaren tachtig en negentig van de vorige eeuw en geven elk op de een of andere manier commentaar op moderniseringen van de Nederlandse samenleving die in de jaren zestig en zeventig daarvoor plaatsvonden. Ze verwerken en herwerken om het populair te zeggen de erfenis van de jaren zestig. ${ }^{4}$ Daarmee is het verband tussen literatuur en samenleving in dit boek al meteen nader gespecificeerd: het is een historisch verband.

In de gedetailleerde tekstanalyses die ik met behulp van het gotieke interpretatiekader zal presenteren, staat de vormgeving van en het denken over de nieuwe maatschappelijke verhoudingen die in de jaren zestig en zeventig ontstonden centraal. Doordat het gotieke in de loop der tijd onlosmakelijk verbonden is geraakt met een vertoog over modernisering - waarover zo dadelijk meer -, ligt bij de verschijning van het gotieke in de romans reflectie over het verleden in het heden voor de hand. In de romans die ik bespreek gaat die reflectie vooral over veranderende sekse- en klassenverhoudingen, de seksuele revolutie, de tweede feministische golf, de homo-emancipatie en de secularisatie. De auteurs van de hier besproken romans hebben zich in meer of mindere mate betrokken getoond bij deze sociaal-historische ontwikkelingen, maar de mate van

\footnotetext{
${ }^{3}$ Zie Brems (2006), p. 372-379. Rond 1980 woedden diverse polemieken die met name over de plaats en taak van de schrijver gingen.

${ }^{4}$ Vaak wordt die periode kortweg onder de jaren zestig samengevat, maar in Nederland vond het geheel van dan bedoelde sociale transformaties voor een deel ook in de jaren zeventig plaats. Van der Klein \& Wieringa (2006) gebruiken in dit verband de term 'de lange jaren zeventig' (p. 15).
} 
openbare persoonlijke betrokkenheid bij deze thema's stond niet voorop bij de selectie van hun werk.

New Historicism betekende een 'turn to history', zoals Brannigan het noemt (Brannigan 1998, 229), maar anders dan traditionele cultuurhistorische benaderingen beschouwen New Historicists de cultuurhistorische context niet als reproduceerbaar feit, maar als een tekst die zelf mede geproduceerd wordt door literaire teksten. De new historicist leeswijze beschouwt het verleden bovendien niet als een coherente eenheid, maar als een arena waarin verschillende stemmen om de macht strijden. Om die verschillende stemmen gaat het mij in dit boek. Via het gotieke ben ik in de literaire teksten op zoek naar de verschillende representaties van en ambivalenties over de verworvenheden van de jaren zestig en zeventig in Nederland.

Frans Ruiter (2000) doet de observatie dat schrijvers als Blaman, Reve, Mulisch, Wolkers en Hermans door literatuurhistorici zijn opgevoerd als wegbereiders van de maatschappelijke omwentelingen in naoorlogs Nederland. Ruiter stelt vast dat dat beeld niet objectief kan zijn: 'Dat toevallig juist allemaal canonieke schrijvers zo'n belangrijke historische rol krijgen toebedeeld, wekt enige argwaan en doet vermoeden dat toch wel van enige narratieve vertekening sprake moet zijn' (Ruiter 2000, 23). Ook Brems (2006) stelt in zijn recente literatuurgeschiedenis dat literatuur in de jaren zestig (Wolkers, Raes, Cremer, Reve) soms een voortrekkersrol had op het gebied van seksualiteit door de grenzen van tolerantie te overschrijden. Seksuele bevrijding was het 'symbool voor een volledig, vitaal en vrij leven en als teken van opstand tegen de vermolmde opvattingen van ouders en opvoeders' (Brems 2006, 259), met andere woorden een typisch teken van moderniteit.

Volgens Ruiter hebben literatuurhistorici de neiging om literatuur als voorloper te beschouwen, maar literatuur kan niet a priori als vooruitstrevend opgevat worden. De afgelopen decennia is de positie van literatuur op de 'cultuurmarkt' bovendien ingrijpend veranderd (Ruiter en Smulders 1996, Vaessens 2009). Literatuur is van richtinggevend geworden tot een uit vele kunstvormen. De dominantie van literatuur als stem in de maatschappelijke arena is afgenomen. Dat vraagt om een meer interdisciplinaire benadering, en om een relativering van de vooruitstrevendheid van literatuur. Geschoold in genderstudies en neerlandistiek zal ik zowel het interdisciplinaire als de kanttekeningen bij het vooruitstrevende recht proberen te doen.

In de vraag 'wat doet het gotieke in Nederlandse literatuur?' kan ten slotte ook verbazing of zelfs een zeker dédain worden gelezen, alsof het over iets gaat wat men niet had verwacht of liever niet had aangetroffen. Zo'n reactie valt bij enkele recensenten van 'mijn' romans te bespeuren. Zo schreef Maarten 't Hart 
over Renate Dorresteins Noorderzon dat haar gothic sprookjes 'wel erg ouderwets' zijn ('t Hart 1986), en besprekers van Kellendonks Letter en Geest haastten zich te benadrukken dat zijn roman geen traditioneel spookverhaal is (Mulder 1982, Warren 1982). Uit zulke opmerkingen spreekt een opvatting dat romans zich niet horen in te laten met 'ouderwetse' genres als het spookverhaal, oftewel dat romans modern moeten zijn. Zo wordt een tegenstelling tussen ouderwetse gotieke roman aan de ene kant en bijdetijdse roman aan de andere kant gecreeerd. Ook de roman als genre wordt kennelijk beoordeeld op zijn moderne gehalte. $^{5}$

Ik ben niet de eerste die een gotiek interpretatiekader gebruikt bij de analyse van Nederlandse romans. In Het heilige huis (2006), de eerste inleidende studie op dit terrein, constateren de cultuurwetenschappers Rosemarie Buikema en Lies Wesseling dat het gotieke zich in allerlei twintigste-eeuwse Nederlandse romans manifesteert. ${ }^{6} \mathrm{Zij}$ analyseren werk van Louis Couperus, Hella Haasse, W.F. Hermans, Gerard Reve, Helga Ruebsamen, Renate Dorrestein, en Herman Franke. Ook bij Buikema en Wesseling komt de (politiek-)culturele functie van de gotieke vertelling aan de orde. Zij lezen de gotieke roman, net als ik in dit boek doe, als een podium waarop spanningen rond modernisering vertolkt worden. ${ }^{7}$

\footnotetext{
${ }^{5}$ Zie ook hoofdstuk 5, waar ik inga op de theorie van Nancy Armstrong, die de geschiedenis van de roman leest als een geschiedenis van het moderne individu.

${ }^{6}$ Vergeleken bij de omvang en de levendigheid van het kritische debat in het Angelsaksische taalgebied, staat de bestudering van het gotieke in Nederland in de kinderschoenen. (Academische) beschouwingen over gothic in Engelstalige fictie zijn schaars, over gothic in Nederlandstalige fictie nog dunner gezaaid. In die tweede categorie zijn er, afgezien van een aantal scripties - Van Poecke (1936), Kunst (1978), Maes (1979), De Jonge (1982), Schuurmans (1982), Daenen (1984), Hilberts (1986) - een twintigtal publicaties. Niet altijd valt daarin de term gothic, soms vormen verwante concepten als zwarte romantiek, fantastische literatuur of spookverhaal het interpretatiekader. Zie Niemeijer (1953), De Geest (1973), Dautzenberg (1979), Haasse (1989), Kuiper (1992), Van Gorp (1993, 1998, 1999), Oppelaar (1995), Buikema (1995, 2001, 2003 , 2003a), Anbeek (1996), Hoekstra (1998), Gaigher (2000), Buikema \& Wesseling (2000, 2006, 2006a, 2007), Andeweg (2005, 2006, 2007, 2007a, 2007b); genoemde titels zijn grotendeels terug te vinden in Schouten (1997).

${ }^{7}$ Voor de naoorlogse periode beschouwen Buikema en Wesseling de maakbaarheids- en huiselijkheidsideologie als belangrijk referentiekader voor de gotieke vertelling. Ze richten zich vooral op de groeiende invloed van een modern, wetenschappelijk gefundeerd deskundigenvertoog (de psy-experts) op opvoeding en gezinsleven. De gotieke vertelling lezen zij als een tegenverhaal van dat moderne, seculiere geloof in maakbaarheid. Terwijl moderne pedagogen huiselijke geborgenheid uitroepen tot basis voor de ontwikkeling van het kind tot autonoom individu, wordt in de homely gothic van schrijvers als Hermans en Reve het huis tot een angstaanjagende plek.
} 
Buikema en Wesseling hebben laten zien dat het gotieke een relevant interpretatiekader is voor Nederlandse literatuur. In dit boek bouw ik voort op hun inzicht. Via de analyse van een ander corpus verken ik de mogelijkheden van een gotiek interpretatiekader. Door in debat te gaan met een groter scala aan literatuurtheorie ga ik meer de diepte in. Daarbij blijken vergelijkbare noties als bij Buikema en Wesseling een belangrijke rol te spelen: het authentieke zelf, de ideologie van zelfontplooiing en maakbaarheid, en nieuwe verhoudingen tussen individu en gemeenschap. Dat wist ik niet op voorhand; dat inzicht is het resultaat van het bijeenleggen van de close readings die in de volgende hoofdstukken zullen volgen. Alvorens deze hoofdstukken te presenteren wil ik in deze inleiding nog een aantal dingen doen. Allereerst zal ik nader ingaan op de vraag hoe ik het concept van het gotieke in dit boek gebruik en ga ik in op historische betekenissen van het gotieke in Groot-Brittannië en Nederland. Vooruitlopend daarop alvast een opmerking over terminologie. Ik gebruik in dit boek de termen 'het gotieke' en 'de gotieke roman', als vertaling van de Engelse begrippen gothic en gothic novel. ${ }^{8}$ Vervolgens bespreek ik de hierboven vermelde band tussen het gotieke en een moderniseringsvertoog en spits ik dit toe op Nederland. Tot besluit van dit hoofdstuk besteed ik aandacht aan (het debat over) female

\footnotetext{
${ }^{8}$ Het meest gangbare bijvoeglijk naamwoord afgeleid van gotiek (znw) in het Nederlands is gotisch, maar gotiek (bnw) is ook toegestaan volgens Van Dale. Omdat gotisch vooral met de taal, de bouwstijl en drukletters wordt geassocieerd (zie paragraaf 'Nederland en het gotieke' verderop in dit hoofdstuk), en gotiek de klankverwantschap heeft met gothic, kies ik voor de laatste aanduiding. Het bestaande zelfstandig naamwoord is 'de gotiek', maar om de term - wederom - te onderscheiden van de architectuur, kies ik voor 'het gotieke'. De grammaticale vorm van verzelfstandigd bijvoeglijk naamwoord heeft ook een inhoudelijk voordeel: die maakt het begrip wendbaarder. In die zin lijkt het gotieke op een begrip als het Unheimliche (tegenover het gangbare Unheimlichkeit), waarover Anneleen Masschelein schrijft: '[G] rammatically speaking, the uncanny belongs to a category of concepts like the grotesque and das Erhabene (the sublime), unlike semantically related nouns like alienation (Verfremdung), or fear (Angst). The connotation of the substantivised adjective seems to lie somewhere in between the closedness and definiteness of the substantive on the one hand, which refers to a clearly demarcated entity or phenomenon, and the adjective on the other hand, which belongs to everyday language with the more versatile, indeterminate use this entails. [...] Like the sublime, the substantivised adjective denotes not an entity but a quality [...]. And yet, the problematic content of these concepts does not prevent them from functioning. (Masschelein 2003, zonder pagina).' Hoewel het Unheimliche zich moeilijk laat definiëren, functioneert het wel als concept, getuige de vele lemma's in encyclopedieën en registers, en het voorkomen van de term in titels en bibliografieën, aldus Masschelein. Datzelfde kan gezegd worden van het gotieke. Overigens maakt het Engelse woord gothic de afgelopen jaren een opmars in Nederlandse kranten; meestal in verband met de gothic subcultuur of gothic muziek, maar ook wel in verband met literatuur. Lexis Nexis (de database van vijf landelijke dagbladen) geeft tussen 1990-2000 184 treffers voor het woord gothic, en tussen 2000-1 sept 2009 meer dan het viervoudige: 820 .
} 
gothic en queer gothic. Deze twee specifieke manieren om het gotieke te lezen zijn van belang voor mijn invalshoek.

\section{VAN GENRE NAAR STRATEGIE}

In de literatuurwetenschap is de gothic novel, of de gotieke roman, doorgaans opgevat als een genre. De gotieke roman maakt volgens deze traditie gebruik van een aantal vaststaande topoi en kent door de eeuwen heen een opvallend vormvast plot. Als founding father van het genre wordt de Britse antiquaar Horace Walpole beschouwd. Hij gaf in 1765 de tweede editie van zijn The Castle of Otranto de ondertitel 'A gothic story' mee. Met de term gothic wilde Walpole zijn ideeën over literatuur en de Middeleeuwen illustreren, zo blijkt uit zijn voorwoord bij die tweede editie. Hij drukte er zijn waardering voor de Middeleeuwen mee uit, en zette zich af tegen classicistische literatuuropvattingen, die naar zijn mening te weinig ruimte boden voor individuele expressie en verbeelding. ${ }^{9}$ The Castle of Otranto is een theatraal en fantastisch verhaal, gesitueerd in middeleeuws Italië, over afstammingskwesties en familiebezit. Uit de lucht vallende helmen, bloedende standbeelden, geheime gangen en bastaardkinderen zetten de toon voor vele navolgers. In navolging van Walpoles klassieker kent de typische gotieke roman een jonge onschuldige held(in), die belaagd wordt door schurkachtige oudere mannen, aristocratisch of (corrupt) katholiek. De setting is in een afgelegen landhuis of ruïneus kasteel, er zijn bovennatuurlijke verschijnselen, en dood, geweld en verval zijn aan de orde van de dag. De sfeer is somber en beklemmend. Al naar gelang de afwegingen van de beschouwers hoorden daar een setting op het Europese continent, of een extatische stijl, of motieven als levend begraven worden bij.

Mede dankzij het succes van Walpoles excentrieke gothic story verschenen tussen 1765 en 1820 talloze verhalen vol bovennatuurlijke verschijningen en griezelige gebeurtenissen, die zich bovendien vaak in de Middeleeuwen afspeelden. Naar schatting bestond veertig procent van de gepubliceerde fictie in Groot-Brittannië rond 1800 uit gothic romances. ${ }^{10}$ Veel daarvan is vergeten geraakt, maar nog altijd bekende Britse gothic novels zijn onder andere Vathek (1786) van William Beckford, The Monk van Matthew Lewis (1796), The Mys-

\footnotetext{
${ }^{9}$ Dat zijn argumenten die ons nu overigens vooral als romantisch in de oren klinken. Romantiek en gotiek zijn dan ook verwant, zie Gamer (2000). Dat wij nu de periode rond 1800 aanduiden met de Romantiek en niet met de Gotiek, zegt volgens hem vooral iets over het verloop van de strijd om de canon.

${ }^{10}$ Zie Mayo (1950).
} 
teries of Udolpho (1797) van Ann Radcliffe, en Mary Shelleys Frankenstein (1818). Melmoth the Wanderer (1820) van Charles Maturin wordt meestal als het einde van de eerste golf gothic novels beschouwd.

Terwijl de gothic novel vaste voet aan de grond kreeg in de literatuurbeschouwing als aanduiding voor een genre, werd het corpus teksten dat met dat etiket kon worden angeduid gaandeweg steeds onduidelijker. Negentiendeeeuwse lezers beschouwden Frankenstein bijvoorbeeld nooit als een gothic novel, maar die roman is voor hedendaagse lezers (denk aan Brakman) samen met Bram Stokers Dracula uitgegroeid tot het prototype van de gotieke roman. Pogingen om de genrenaam uitsluitend te reserveren voor de eerste golf (17651820) bleken vergeefs: het gotieke leeft voort tot op de dag van vandaag. Jane Eyre (1847) van Charlotte Brontë werd een klassieker en aan het eind van de negentiende eeuw verscheen opnieuw een golf gothic novels: The strange case of Dr Jekyll and Mr Hyde (1886), The picture of Dorian Gray (1891), The Island of Dr Moreau (1896), The Beetle (1897), en niet te vergeten Dracula (1897). In de twintigste eeuw is het etiket gothic toegekend aan allerlei romans, zowel uit de 'hoge' als de 'lage' literatuur. Margaret Atwood, Stephen King, John Banville, Toni Morrison, Donna Tartt, Anne Rice, Angela Carter - het zijn allemaal voorbeelden van Engelstalige laattwintigste-eeuwse auteurs wier werk gothic is genoemd. Inmiddels wordt ook het werk van zeer uiteenlopende - en voorheen niet als gothic beschouwde - schrijvers als Charles Dickens en T.S. Eliot als gothic gelezen (Houston 2005, Hughes 2008) en is Walpoles positie als oervader van het genre betwist (Clery 1994). Robert Platzner en Robert Hume constateren dan ook:

There is in an objective sense no such thing as The Gothic Novel; rather there are a variety of novels from different periods and countries which, on the basis of similarities, we may want to categorize as a group. (Platzner \& Hume 1971, 273)

De grote variatie in periodes, thematiek, vorm en stijl heeft vele auteurs ertoe gebracht om te zoeken naar een andere term dan genre om het gotieke te benoemen. Zo spreekt Donald Ringe (1982) over een gothic mode, kiest Robert Miles (1993) voor de term shifting aesthetic, Ann Williams (1995) voor poetics, en Judith Halberstam (1995) voor narrative technique. Sommige anderen benadrukken juist de functie van het gotieke. Zij omschrijven het gotieke als de uitdrukking van het verdrongene van de Romantiek (Bruhm 1994, Day 1985), of 
als een expressie van 'extreem' psychologisch of sociaal-politiek bewustzijn (Cox 1992, Halberstam 1995, Monléon 1990, Paulson 1981, Richter 1996). ${ }^{11}$

Met zulke omschrijvingen wordt het gotieke niet zozeer benoemd naar literair-formele aspecten, maar naar zijn functie, naar wat het teweegbrengt. ${ }^{12}$ Dat heeft als belangrijk voordeel dat ook literaire teksten die niet direct als gothic novel worden (h)erkend, met een interpretatiekader benaderd kunnen worden dat over het algemeen gebruikt wordt om gothic novels te analyseren. Bovendien kunnen de verbanden met het gotieke in andere cultuuruitingen zichtbaar gemaakt. Zoals Allan Lloyd-Smith en Victor Sage (1994) stellen: 'Gothic is not so much a literary genre as a broader cultural response, and as such is reducible neither to the purity of origins nor the purity of literary form.' (Lloyd-Smith \& Sage, 1994, v).

Literatuurwetenschappers hebben sinds de jaren tachtig van de twintigste eeuw wel steeds meer aandacht voor een dynamisch genrebegrip. In de genretheorie wordt genre tegenwoordig steeds minder als een statische, formele categorie, steeds minder als een vaststaand repertoire opgevat. ${ }^{13} \mathrm{Om}$ te voorkomen dat men toch teveel taxonomische associaties houdt, heeft een andere term dan genre hier echter mijn voorkeur. In dit boek staat de functie van het gotieke centraal. De zes romans zijn weliswaar in eerste instantie geselecteerd op het gebruik van gotieke topoi, in de analyses ervan richt ik me op het culturele werk van het gotieke in de tekst. Ik geef er daarom de voorkeur aan om het gotieke op te vatten als een culturele strategie, ik doel daarbij overigens niet per se op een bewuste strategie. Ik ontleen de term strategie in dit verband aan het werk van Barbara Fuchs (2004) die hem gebruikt voor romance, dat net als het gotieke een zeer beweeglijk concept is. Fuchs betoogt niet alleen dat de term genre een te statische connotatie heeft, maar ook dat het teveel een exclusief-literaire term is. Dat is in het geval van romance - en ook in het geval van het gotieke - niet wenselijk. De term culturele strategie omvat dus niet alleen narratologische elementen en topoi van gotieke romans, maar kan ook verschijningen van het gotieke buiten de literatuur aanduiden, of het voorkomen van het gotieke in

\footnotetext{
${ }^{11}$ Dit overzicht ontleen ik aan Gamer (2000), p. 28.

${ }^{12}$ Zie ook Van Gorp (2000), p. 47 e.v., die pleit voor wat hij noemt een 'dynamisch-functionele benadering' van het genre.

${ }^{13}$ Genre is bijvoorbeeld omschreven als een historisch veranderlijk sociaal instituut dat bemiddelt tussen lezer en schrijver (Fowler 1982); of er wordt benadrukt dat een genre behalve een 'conventional repertoire of stock motifs and themes' ook een 'set of strategies for the literary representation of these thematic elements' is (Wesseling 1991, 17-18). Definities van genre zijn niet meer louter taxonomisch van aard, maar gericht op 'the action it is used to accomplish' (Miller 1994, 24).
} 
teksten die duidelijk een ander genre hebben. Het gotieke als culturele strategie is historisch veranderlijk en manifesteert zich in uiteenlopende contexten. Hoewel de verschijningsvormen variëren, kent het ook een aantal opmerkelijke constanten. Omdat voor mijn opvatting van het gotieke de historische betekenissen van het woord van belang zijn, ga ik daar eerst iets dieper op in.

\section{OVER GOTEN EN BRITTEN}

Over de vraag wat het gotieke is wordt vooral in het Engelse taalgebied al decennia gediscussieerd en nog steeds opent ieder nieuw handboek met de vraag 'what is (the) gothic?' (Spooner \& McEvoy 2007, 1; Wright 2007, 1). Het gotieke laat zich niet gemakkelijk in een definitie vangen, zoveel is duidelijk, en volgens Punter $(2000, \mathrm{x})$ is juist die beweeglijkheid van het concept een van de kenmerkende eigenschappen ervan. Het is inderdaad opvallend hoeveel verschillende betekenissen het gotieke heeft gekregen, en in hoeveel verschillende contexten het voorkomt. Tegenwoordig komen we de term gothic bijvoorbeeld tegen in film, literatuur, graphic novel, popmuziek, mode en subcultuur. ${ }^{14}$ Voordat het begrip in de achttiende eeuw - in Groot-Brittannië - in verband werd gebracht met literatuur, was het een term die etnische, geografische, en vanaf de zestiende eeuw ook esthetische connotaties had (in de bouw- en schilderkunst).

Gothic (of gothique, gothisch, gotico) verwees in den beginne naar een Germaanse stam: de Goten. Zij vielen Rome binnen in 476 en groeiden in de Westeuropese overlevering uit tot de verwoesters van het Romeinse Rijk, wat algemeen werd gezien als het begin van de Middeleeuwen. In de Renaissance, de herontdekking van de Romeinse en Griekse cultuur, zette men zich af tegen de 'barbaren' die het klassieke ideaal ooit hadden doen verdwijnen. Het is aan de Italiaanse kunsttheoreticus Giorgio Vasari (1511-1574) te danken dat gotiek synoniem werd met middeleeuws, barbaars en chaotisch. Schrijvend over de bouwstijl van de middeleeuwse kathedralen, die hij als Germaans identificeerde, legde hij ten onrechte een verband met de Goten. ${ }^{15}$ De gotische stijl, met de

\footnotetext{
${ }^{14}$ Voor onderzoek naar gothic in subcultuur: Hodkinson (2002); in mode zie Spooner (2006), in hedendaagse kunst zie Grunenberg (1997), zie verder Spooner \& McEvoy (2007).

${ }^{15}$ Een vergissing, want de Goten hadden met de kathedralen hoegenaamd niets van doen. De bouwstijl ontstond in Frankrijk. Zie De Beer (1948) voor een uitgebreid overzicht van het ontstaan en de verspreiding van de term gotiek in de architectuur. Vasari zelf gebruikte gotisch nog niet als stilistische term; hij noemde de stijl 'tedesco' (Duits) maar schreef dat de Goten zo bouw-
} 
bekende spitsbogen, kreeg zijn naam om de (onregelmatig en grillige) gotiek af te zetten tegen de (regelmatige) klassieke bouwstijl, net zoals de Goten tegenover de Romeinen hadden gestaan. Ook de gotische letter kreeg zijn naam in de Renaissance, en die benaming diende eveneens om het barbaarse en middeleeuwse karakter ervan te aan te geven. ${ }^{16}$

In Groot-Brittannië onderging de term gothic in de zeventiende eeuw een aantal betekenisveranderingen. ${ }^{17}$ Behalve in een geografische (Germaans) of historische (verwijzend naar de Goten) context, kreeg het begrip ook betekenis in politiek-culturele zin. ${ }^{18}$ Gothic bleef geassocieerd met het primitieve, maar kreeg nu ook een positieve associatie. Het begrip ging verwijzen naar de ware, oorspronkelijke cultuur, die verloren was gegaan of dreigde te gaan. De Goten inmiddels een verzamelnaam voor alle Germaanse stammen - werden niet meer als barbaarse vreemdelingen beschouwd, maar als de Angelsaksische voorvaders van de Engelsen en vestigers van de democratie, met een beroep op de Romeinse schrijver Tacitus. Die had in zijn Germania (98 AD) met een zekere waardering geschreven dat de Goten volksraadplegingen hielden. ${ }^{19}$ "The myth of Gothic origins was fundamental to an emergent sense of British national distinctiveness', schrijven Clery en Miles (2000, 48); een mooi voorbeeld van wat de historicus Eric Hobsbawm (1983) de invention of tradition zou noemen.

In de tweede helft van de achttiende eeuw, terwijl de herwaardering plaatsvond van de gotiek, kreeg gothic voor het eerst betekenis in een literaire context,

den: 'Questa maniera fu trouata da i Gothi' (geciteerd in De Beer (1948), p. 147, noot 1). Die historische vergissing werd door auteurs na hem overgenomen.

${ }^{16}$ In de drukkunst staat het gotische lettertype tegenover het Antiqua lettertype - daarin klinkt de antieke beschaving mee, net zoals in de Times Roman de Romeinen meeklinken. De Antiqua kreeg uiteindelijk de overhand omdat van die letter ook een schuinschrift mogelijk was (italics geheten in het Engels).

${ }^{17}$ Ook in het Frans wordt 'gothique' in de tweede helft van de achttiende eeuw wel gebruikt in verband met literatuur, aldus Holbrook (1941), zij het niet in de Engelse betekenis van bovennatuurlijk of spookachtig. In het Frans zijn 'pièces gothiques' ouderwets of neutraler 'pre-klassiek'. Verwees het woord eerst vooral naar (barbaarse) zeden en gebruiken, in de architectuur krijgt gothique de bijbetekenis 'melancholiek'. Na 1830 krijgt de oudere betekenis 'ouderwets, uit de tijd' weer de overhand (Holbrook 1941).

${ }^{18}$ Het debat over die politieke betekenis van gothic bereikte echter pas in de jaren 1790 zijn hoogtepunt, precies in de periode dat ook gothic novel zijn grootste populariteit beleefde (Clery \& Miles 2000, 48).

${ }_{19}$ Als zodanig werden ze door de anti-monarchistische en anti-Franse Whigs opgevoerd. Zie Longueil (1923), Kliger (1952), Clery \& Miles (2000) m.n. hoofdstuk 2 waarin de historische tekstfragmenten zijn opgenomen, Punter \& Byron (2004), Miles (2007). Ook in de Verenigde Staten schreef men de wortels van de democratie toe aan de Goten. Zie Marsh, The Goths in New-England (1843), geparafraseerd door Lowenthal (1985), p. 336, noot 233. 
dankzij de eerder genoemde Horace Walpole. ${ }^{20} \mathrm{Hij}$ mengde zich volgens literatuurwetenschapper Emma Clery niet uitsluitend in een literair debat, maar ook in een sociaal-economisch vertoog over klassenhiërarchie (Clery, 1994). Opnieuw werd gothic gebruikt als tegenovergestelde van klassiek, maar ditmaal als geuzennaam.

In het Nederlands is het begrip gotiek hoogst zelden geassocieerd met literatuur of een literair genre. ${ }^{21}$ Het Etymologisch Woordenboek dateert het ontstaan van 'gotisch' (als de benaming van het volk) met een vindplaats uit 1632 (waar het woord 'gotse' is) en met een vindplaats uit 1717 ('gottisch'). De auteurs vervolgen: 'De benaming van de stijl dateert uit ca. 1820, toen in de romantiek de belangstelling voor de Middeleeuwen ontwaakte, maar werd overgenomen uit het it[aliaanse] gotico voor Germaanse kunst'. ${ }^{22}$ In het Woordenboek der Nederlandsche Taal (WNT) blijkt het woord 'gothiek' of afgeleiden daarvan in de eerste plaats te betekenen 'van de Goten afkomstig' (taal, wetboek, bijbelvertaling). In de tweede plaats is het de benaming voor de bouwstijl, waarbij wordt opgemerkt: 'ten onrechte aan de Gothen toegeschreven'. ${ }^{23}$ In zo'n tachtig WNT

${ }^{20}$ In Groot-Brittannië beleefde de architectuur een Gothic Revival (Walpoles zelfontworpen Strawberry Hill is daarvan een voorbeeld). Op het continent prees Goethe de gotische kathedraal van Straatsburg in zijn Italienische Reise (1786-1788), die men tot dan toe een wangedrocht vond. Met dank aan Joep Leerssen.

${ }^{21}$ Ter illustratie: de Amerikaanse schrijfster Mary McCarthy zocht in haar Huizingalezing 'Can there be a gothic literature?' (1973) naar formele overeenkomsten tussen de gotische architectuur en literatuur uit dezelfde periode maar kon die niet ontdekken (evt. met uitzondering van Dante en Chaucer). Zij was opgelucht te horen dat gothic in Nederland sowieso niet naar literatuur verwees: ' $[\mathrm{A}]$ Dutch friend told me that in Holland my title had been a source of mystification: in Holland, the word 'Gothic' was applied only to buildings. This news was rather shattering and yet I was glad to hear it. Glad to know that in this clear-headed country at any rate my lecture was otiose, unnecessary: nobody had ever thought that there could be a Gothic literature' (McCarthy 1973, 33). De uitzondering die de regel bevestigt is wellicht de bundel Kleine Romans en Gothische Vertellingen. Uit het Engelsch verschenen (1815). Hendrik van Gorp noemt 'het attribuut "gothisch" in de titel [...] hier wel opvallend' (Van Gorp 1999).

${ }^{22} 1820$ lijkt mij rijkelijk laat. Volgens De Beer (1948) verbreidt de naam voor de stijl zich in de $17^{\mathrm{e}}$ eeuw vanuit Italië. Hij geeft twee vroege vindplaatsen in de zuidelijke Nederlanden, zij het niet in het Nederlands, beide in Antwerpse geschriften: een uit 1610 (van de Jezuïet C. Scribianius, over de Antwerpse Beurs; in het Latijn) en een uit 1622 van Rubens (in het Italiaans, voorwoord bij Palazzi de Genova). Het WNT geeft een citaat van Justus van Effen (die in 1735 overleed) dat er ook op wijst dat de stijlnaam al eerder bekend was: 'De Gothische Bouworder, van welke nog zo veele onaardige blyken, door gansch Europa, de geleerde oogen aanstootelyk voorkomen' (Van Effen, Spectator 11, 74). Het citaat dateert duidelijk van voor de herwaardering van de stijl. Hetzelfde geldt voor Constantijn Huygens, zie noot 24.

${ }^{23} \mathrm{Ik}$ heb gezocht naar betekenissen van gotiek, gotisch en afleidingen Het WNT, gestart in 1851, werd voltooid in 1998. Het zwaartepunt van de bronnen van het WNT ligt op de eerste helft van de $19^{\mathrm{e}}$ eeuw, maar de eerste samenstellers gebruikten ook veel $17^{\mathrm{e}}$-eeuws materiaal. Omdat het 
lemma's heeft gothiek/gothisch vrijwel uitsluitend die twee betekenissen (Goten en bouwstijl). Onder het lemma 'gothisch' is een derde betekenis te vinden: 'Eene enkele maal treft men, gelijk in 't Fransch en Hoogduitsch [...] ook in onze taal gothisch aan in den bepaalden zin van: uit de barbaarsche middeleeuwen afkomstig.' Net als in Groot-Brittannië kreeg het gotieke in eerste instantie een negatieve naar de Middeleeuwen verwijzende betekenis. ${ }^{24}$ In Nederland lijkt die negatieve bijklank lange tijd te blijven hangen en wordt de term niet zoals in het Engels voor politieke of literaire doeleinden ingezet. De auteurs van het WNT schrijven halverwege de negentiende eeuw: 'Oorspronkelijk [...] is het woord [gothisch] alles behalve een eernaam'. Daarbij speelde associaties met extreem, zedeloos, sensatiezucht en een teugelloze verbeelding een grote rol. ${ }^{25}$

Dit korte overzicht laat zien dat gotisch, of gothic impliciet of expliciet onderdeel is van een tegenstelling: Gotisch-Romeins, Germaans-Italiaans, middeleeuws-klassiek; oftewel (normatief) barbaars-beschaafd, chaotisch-ordelijk. Gotisch is sinds Vasari in zekere zin een periode-aanduiding (middeleeuws), maar die aanduiding is zelden neutraal.

\section{DE BREUK TUSSEN TRADITIE EN MODERNITEIT}

Voor Robert Mighall (1999) zijn de historische betekenissen van het begrip gothic aanleiding te stellen dat 'the "Gothic" by definition is about history and geography' (Mighall 1999, xiv). Zijn belangrijkste inzicht is dat het gotieke een dynamisch begrip is, maar een constante functie heeft. Het gotieke markeert volgens Mighall steeds een breuk tussen heden en verleden, en conceptualiseert die breuk in termen van modern en ouderwets - of het nu bouwkunst, politiek of literatuur betreft. Dit inzicht is belangrijk voor mijn boek.

\footnotetext{
digitale WNT ook te doorzoeken is op het voorkomen van een woord in het hele woordenboek (en dus niet alleen als lemma), is gemakkelijk na te gaan in welke contexten gotiek voorkomt.

${ }^{24}$ Als voorbeeld van de oorspronkelijke negatieve bijklank wordt Constantijn Huygens (15961687) geciteerd: 'Van Campen, dien die eer voor eewigh toe sal hooren / Van 't blinde Nederlands mis-bouwende gesicht / De vuyle Gotsche schell te hebben afgelicht.' Anderhalve eeuw later is Willem Bilderdijk (1756-1831) nog geen liefhebber, getuige zijn regels over de St. Paul's kathedraal in Londen: 't log wanschapen blok, door wansmaak zonder zout / Naar Bastaardgrieksche Kunst in Gothschen geest gebouwd.'

${ }^{25}$ In het WNT lemma 'verdichtsel' is het volgende citaat te vinden: 'Men gebruykt-er ("in de Nederduytsche scholen")...boeken met wat te gotieke letters en zeer gotieke gedagten,....sommige vol enkele grofgeestige verdigtsels zonder iets zedigs, zommige vol onnoozelheden en aldertastbaerste leugens, niet als fabels, maar als waerheyd voorgegeven. (Verlooy Verh. 92 , 1788).'
} 
In gotieke romans worden de spanningen tussen heden en verleden zichtbaar door de vele anachronismen, aldus Mighall. Anachronismen vormen in gotieke romans een bron van chaos of angst: een eeuwenoude graaf (Count Dracula) duikt op in het negentiende-eeuwse Londen, of een moderne achttiende-eeuwse jonge vrouw vindt zichzelf terug in een feodale, middeleeuwse setting (alle romans van Ann Radcliffe). Mighall ziet in de gotieke roman een sterke notie van ontwikkeling (modernisering, vooruitgang) terug: ${ }^{26}$

The Renaissance needed a myth of Gothic ignorance, as the English tourists needed their myth of Catholic stagnation, as the anthropologists needed to equate savages with primitives and primitives with criminals. In each case the stagnation, the anachronism, of the object ensures the modernity of the subject. Progress has been the dominant idea in organizing post-Renaissance thought in the West. And ideas of progress [...] have provided their antitheses, their own myths of Gothic stagnation and oppression. (Mighall 1999, 286)

Mighall noemt gotieke fictie daarom 'essentially Whiggish' (7). Daarmee bedoelt hij dat gotieke romans 'dramatize a conflict between representatives of "modernity" and those who stand for the past' (7) ${ }^{27} \mathrm{Hij}$ stelt dat de moraal van gotieke romans uiteindelijk een bevestiging vormt van de bestaande verhoudingen, waarin vooruitgangsdenken dominant is.

Daarmee neemt hij stelling in een van de terugkerende debatten in gothic criticism: moet het gotieke gezien worden als een 'subversief fenomeen of niet? In veel beschouwingen fungeert de gotieke roman als een cultuuruiting die typische Verlichtingsidealen als de vooruitgang door de rede en het autonome subject ondermijnt. Mighall maakt bezwaar tegen benaderingen van het gotieke als per definitie revolutionair of subversief. Zelf slaat hij door naar het andere uiterste: dat het gotieke altijd leidt tot een bevestiging van de moderne orde. Er

\footnotetext{
${ }^{26}$ Het anachronisme-concept wordt door diverse historici beschouwd als deel uitmakend van het moderne historische besef. Het krijgt betekenis vanuit een ontwikkelingsperspectief op de geschiedenis. Zie Lowenthal (1985, xvi) en Blaas (1988). Het ontstaan van dit nieuwe historisch besef wordt door Koselleck (1979) gedateerd tussen 1750-1850, toen West-Europese samenlevingen snel veranderden onder invloed van de Industriële en de Franse Revolutie. Zie ook Fritzsche (2001). De eerste generatie gotieke romans (1765-1820) valt in die periode.

${ }^{27}$ De term 'a whiggish view on history' - afkomstig van Herbert Butterfield (The Whig Interpretation of History, 1931) - staat voor een normatieve opvatting van geschiedenis, waarin de geschiedenis een pad van onvermijdelijke vooruitgang volgt en het verleden wordt beoordeeld in het licht van het heden. Zie ook Stuurman (2001), die uitlegt dat in de achttiende eeuw de notie 'filosofische geschiedenis' ontstaat, waarin tijd wordt gedacht als 'ontwikkeling'.
} 
zijn echter ook voorbeelden van gotieke romans die wel degelijk als tegengif tegen de moderniteit gelezen kunnen worden. ${ }^{28} \mathrm{Ik}$ kies op dit punt voor een genuanceerder standpunt dan Mighall: de uitkomst staat niet vast. ${ }^{29}$ Het zal van de roman en van de interpretatie afhangen naar welke kant de balans doorslaat.

Eerder noemde ik de gotieke roman een podium waarop spanningen rond modernisering vertolkt worden; met Mighall kan ik nu stellen dat het een verrijdbaar podium is. Elke periode creëert namelijk zijn eigen gotieke verleden, of in Mighalls woorden: 'what is Gothicized constantly changes' (Mighall, 1999, 286). Terwijl de Britse achttiende-eeuwse romans zich vaak in een middeleeuwse setting afspelen, bijvoorbeeld in een kasteel (zie bijv. The Castle of Otranto, The Monk, Mysteries of Udolpho), zo zijn hedendaagse gotieke romans vaak gelokaliseerd in negentiende-eeuwse verlaten huizen. Voor de achttiende eeuw waren de Middeleeuwen het gotieke verleden, voor de twintigste eeuw de Victoriaanse tijd. Ik onderzoek welke specifieke historische vorm het gotieke aanneemt in Nederlandse romans, aan het eind van de twintigste eeuw. Hoe worden daar en dan conflicten tussen modern heden en archaïsch verleden geënsceneerd, en wat vormt precies de bron van spanningen - welk verleden wordt er als gotiek verbeeld?

De romans die ik in dit boek analyseer verschenen tussen 1981 en 1995. Ik lees die romans als een reflectie op de snelle moderniseringsprocessen die $\mathrm{Ne}-$ derland in de periode daarvoor, in de jaren zestig, doormaakte. ${ }^{30}$ Volgens de historicus James Kennedy veranderde 'geen enkel land in West-Europa (mogelijk met uitzondering van Italië) [...] meer dan Nederland' (Kennedy 1995, 10). Al snel groeide Nederland uit tot een icoon van seksuele bevrijding, tolerantie en progressiviteit; ook in de ogen van het buitenland. Kennedy citeert de historicus H.W. von der Dunk, die in 1975 opmerkte: 'Nederland heeft zich in het laatste decennium ontwikkeld tot het meest anti-traditionalistische land van het Westen...' (Kennedy 1995, 11). Kennedy verklaart de snelle culturele transformaties die Nederland doormaakte uit een overheersende vernieuwingsreto-

\footnotetext{
${ }^{28}$ Zie bijvoorbeeld Catherine Spooner (2007) over Lovecraft, die Mighall op dit punt bekritiseert.

${ }^{29}$ Evert van Leeuwen gebruikt in navolging van Alan Sinfield de term 'dissidente' fictie voor gothic fiction. Met die term wordt - anders dan 'subversief - geen resultaat gesuggereerd, maar wel de weigering van een bepaald aspect van de dominante orde. Van Leeuwen citeert Sinfields bezwaar tegen de term subversie: 'since mostly the government did not fall, patriarchy did not crumble, [...] containment must have occurred' (Sinfield geciteerd in Van Leeuwen 2006, 13).

${ }^{30}$ Dat heeft in het geval van De vierde man als consequentie dat ik een andere interpretatie heb dan Buikema en Wesseling, die deze roman van Gerard Reve ook analyseren. Zie verder hoofdstuk 3.
} 
riek die niet alleen protestgroepen maar ook de maatschappelijke elite in zijn greep had:

Het wijdverbreide geloof in de onverbiddelijke komst van het 'moderne leven' is één van de fascinerendste aspecten in de denkwereld van de Nederlandse elites in de jaren zestig. Velen getuigden van hun geloof in de onvermijdelijkheid van verandering, en meenden dat de enige verstandige beslissing kon zijn van de nood een deugd te maken. (Kennedy 1995, 16)

Kennedy maakt aannemelijk dat er een breed gedeelde noodzaak werd gevoeld om 'bij de tijd zijn'. Het moderniteitsvertoog domineerde met andere woorden het publieke debat. ${ }^{31}$ Dat is volgens Kennedy de reden dat de verschillende emancipatiebewegingen relatief snel en geweldloos successen behaalden. ${ }^{32} \mathrm{Om}$ die vernieuwingsretoriek is het mij te doen. Onderdeel van die retoriek is dat het verleden wordt beschouwd als passé, uit de tijd; door Kennedy samengevat als 'wat was is voorbij, en dat is maar goed ook' (Kennedy 1995, 20). Het gotieke maakt het breukvlak tussen oud en nieuw zichtbaar, tussen ouderwets verleden en modern heden. Literaire auteurs kunnen met behulp van het gotieke eventuele ambivalenties bij het schijnbaar rimpelloze Nederlandse vooruitgangsverhaal verbeelden. In dit boek ga ik op zoek naar dat soort ambivalenties, maar eerst geef ik in de volgende paragraaf een kort overzicht van de positie van de gotieke roman in Nederland.

\section{NEDERLAND EN HET GOTIEKE}

Groot-Brittannië spant de kroon als het gaat om aantallen gothic novels in de loop der tijd. Maar ook in Duitsland en Frankrijk verscheen vanaf eind acht-

\footnotetext{
${ }^{31}$ Het begrip moderniteitsvertoog ontleen ik aan Koenis (2008). Hij legt uit dat Kennedy modernisering beschouwt als 'een concept en (geseculariseerde) mythe waardoor deze werkelijkheid mede wordt vormgegeven', aldus Koenis $(2008,57)$. Dat kwam Kennedy op kritiek te staan van sociologen die modernisering opvatten als een sociologische theorie die ontwikkelingen in de werkelijkheid verklaart (zie bijv. Kennedy 1997). De historicus Hans Righart, die zelf een boek over jaren zestig schreef vanuit het perspectief van een generatieconflict (Righart 1995), bekritiseerde Kennedy om zijn monolithische opvatting van moderniteit, die te weinig ruimte zou laten voor per groep verschillende opvattingen van wat modern was. Righart vergeleek die zelfs met de 'Whig interpretation of history' (Righart 2001, 98). Sic! Koenis (2008) stelt dat er in de politiek pas recentelijk deuken zijn ontstaan in het geloof in de modernisering van Nederland. Er was tot voor kort geen conservatieve positie voorhanden.

32 Zie Duyvendak (1994) over het snelle succes van de homobeweging.
} 
tiende eeuw een respectabele hoeveelheid griezelromans (Schauerroman, roman noir). In dat kader staat Nederland bekend als een buitenbeentje. De bibliografie over Nederlandse griezelliteratuur van Dennis Schouten en het werk van Hendrik van Gorp laten zien dat Nederland door de eeuwen heen een zeer geringe productie van eigen bodem had. (Schouten 1997, Van Gorp 1993, 1999). In de periode dat de gothic novel elders op zijn hoogtepunt was, dus rond 1800, werden er in de lage landen wel enkele ridder- en roverromans geschreven die met wat goede wil voor gotiek door kunnen gaan. Ook was er wat volkstoneel met 'spektakel [...] pathos, [en] gruwelen'. ${ }^{33} \mathrm{Na} 1820$ ziet Van Gorp een vermenging tussen gothic novel en historische roman in Nederland ontstaan: in Jacob van Lennep (De pleegzoon 1833), Adriaan van der Hoop Jr. (La Esmeralda 1837, een bewerking van Victor Hugo's Notre Dame de Paris en De Renegaat 1838) en Hendrik Arnold Meijer De Boekanier (1840). ${ }^{34}$ Rond 1845 noteert Van Gorp 'zelfs een [bescheiden] piek van gothic novels' (Van Gorp 1999, 192) - Schouten noemt de namen van Michiel Adriaan, J. Krabbendam en A.D. van Buren Schele - en treffen we een enkel spookverhaal aan van (nu vergeten) auteurs als Alexander Ver Huell ${ }^{35}$ en Isaac van Rennes, maar veel heeft het niet om het lijf.

Ondanks de geringe productie was het gotieke in Nederland in de periode 1800-1850 niet afwezig, concludeert Van Gorp:

De Engelse gothic novel, de Duitse Schauerroman en de Franse roman noir hebben geen typisch Nederlandse tegenhanger opgeroepen, maar wel hun sporen achtergelaten in diverse vormen van mediatie (vertalingen, bewerkingen), consumptie en navolging. [...] [D]e gothic [was] als discussieonderwerp wel degelijk aanwezig en [raakte] zelfs de kern van het standaardbetoog over literatuur (zedelijke verheffing en strijd tegen bijgeloof). (Van Gorp 1999, 196)

\footnotetext{
33 'het toneel in het Zuiden, dat van de rederijkerskamers maar ook dat van de vrije kamers en de losse gezelschappen, was volkstoneel, gericht op het effect: spektakel dus, pathos, gruwelen en soms rauwe taal' (Kloek 2005, 9).

${ }^{34}$ Andere voorbeelden zijn Rowna (1845) het debuut van de jonggestorven Vlaamse schrijver Eugeen Zetternam, door Stynen (1997) een roman met 'gothic novel-allure' genoemd (p. 52); te denken valt ook aan Nicolaas Beets' zwart-romantische drama Guy de Vlaming (1837), genoemd door Mathijsen (2009).

${ }^{35}$ Bij Mathijsen (2004) komt Ver Huell voor als tekenaar en als vriend van Kneppelhout, niet als auteur van het spookverhaal 'No 470, Hoogerwoerd' (opgenomen in Schouten 1997). Over dit verhaal schreef Bervoets (1982).
} 
Op basis van zijn werk geef ik hier een korte impressie van het karakter van die aanwezigheid. De gothic rage, in een recensie uit 1801 beeldend aangeduid als een naderend onweer, ontstond volgens de eigentijdse critici in Duitsland, trok vervolgens naar Engeland, om van daaruit in het Frans vertaald te worden en tenslotte in het Nederlands. Er waren dus vertalingen uit het Duits en Frans beschikbaar, die tot ver in de negentiende eeuw zeer populair waren. ${ }^{36}$ Engelse auteurs werden overigens nauwelijks vertaald, met uitzondering van Ann Radcliffe, wier werk vaak via het Frans in het Nederlands werd vertaald (of bewerkt tot toneelstuk). ${ }^{37}$

Vertalingen van gothic novels werden volgens Van Gorp gelezen en bediscussieerd en waren ook halverwege de negentiende eeuw nog populair, getuige het volgende citaat uit 1853 waarin Octavius Kwarto (pseudoniem van J. de Vries) de voorkeuren van het publiek bij een populaire leesbibliotheek beschrijft: ${ }^{38}$

${ }^{36}$ Een overzicht in Buisman (1960). Tot de vertaalde auteurs behoorden onder anderen H. Zschokke, Veit Weber (vertaald door Rheinvis Feith), C.A. Vulpius, A. von Kotzebue, C.H. Spiess, C. Naubert, maar ook Schiller (Der Geisterseher en Die Räuber) en Franse auteurs als F. Ducray-Duminil en J.J. Regnault Warin, maar ook Diderot (La Religieuse). Zie ook Van Gorp (1999) en Schouten (1997).

${ }^{37}$ Vertalingen van Ann Radcliffe: De Italiaan [...] (Amsterdam 1821) en De geheimen van Udolpho (Amsterdam 1823). Haar Sicilian Romance (1790) werd het eerst vertaald, als De Bouwval (1793). Van de Engelstalige auteurs werd alleen Charlotte Smith zo snel vertaald (Emmelina (1788) verscheen tussen 1793-1797 in het Nederlands). In de jaren 1830 verschenen er vertalingen van Beckford (Vathek 1786; door Potgieter) en Clara Reeve (The champion of virtue 1777). Andere - nu klassieke - gothic novels moesten veel langer wachten: Shelleys Frankenstein werd in 1947 vertaald, Walpoles Castle of Otranto in 1982; en Lewis' The Monk werd na een ingekorte vertaling uit 1968 pas in 2003 voor het eerst compleet in het Nederlands uitgebracht. The Monk was wellicht wel bekend via een Franse vertaling. Een uitgave uit 1822 van De geheimen van de toren van St. Johannis, of de tempel-ridders werd op de titelpagina toegeschreven aan 'Lewis, schrijver van "Den Monnik", maar het ging om een mystificatie van E.L. de Lamothe. De vermelding van Lewis' naam en titel door de Nederlandse uitgever zou de lezer het signaal geven dat het niet om een historische roman, maar om een zgn. 'kloostergeschiedenis' of schrikroman ging. Met dank aan Toos Streng.

${ }^{38}$ Die voorliefde van het publiek bestond ook al rond 1800 en ging ten koste van 'serieuze' auteurs als Wolff \& Deken, zo is door diverse auteurs opgemerkt: 'De smaak van het publiek bleek meer gericht op thriller-achtige ontspanningslectuur ('gothic novel') of sentimenteel kleingoed dan op solide zedenschildering in de trant van Wolff en Deken.' (Buijnsters (1986, p. 15). Kloek en Mijnhardt (2001) schrijven dat Wolff \& Dekens uitgever in 1800 meer geïnteresseerd was in vertalingen dan in oorspronkelijk werk van hun hand. Van den Berg leest in een apologetische passage in Sara Burgerhart (1782) een sneer naar de roman noir: 'Men vindt in deeze Roman geen wandaden, die een Engelschman zelf met rilling leest; geen zo overdreven deugden, dat zy voor ons zwakke menschen onbereikbaar zyn. [...] Daar wordt in dit gehele werk geen een Duël gevogten. [...] Er wordt noch geschaakt, noch vergif gedronken. Ons vernuft heeft niets wonderbaarlyks uitgedagt. Alles blyft in het natuurlyke' (geciteerd in Van den Berg 1981 p.171). 
"Hebt u ook de Geheimenissen van Udolpho, of wel de Italiaan, of de Biechtstoel der zwarte Boetelingen van Radcliffe, of eenige andere ijsselijke geschiedenisse; maar ze moet wel ijsselijk, razend, erg akelig zijn" vroeg eens een lieve meid, die luchtig den winkel kwam binnenstappen, aan Octavius. "Zijt ge dan zoo groot liefhebster om ijsselijke geschiedenissen te lezen?" vroeg de houder der bibliotheek.

"Jongen ja, Mijnheer, maar het moet zeer afgrijselijk zijn."

"Dan zal ik u Twee Lijken geven van Frederic Soulié."

"Komt daar veel in van moorden en branden?"

"O ja, het boek is er vol van; van het opgraven van lijken, ophangen en radbraken, zoo ijsselijk als maar in de verbeelding van een' mensch is kunnen opkomen."

"En komt er ook van spoken in?"

"Neen van spoken niet, voor zooveel ik mij herinner; maar des te meer van levende monsters."

"Geeft u me dat boek dan maar, Mijnheer."

"Ja, maar ge moet het spoedig uitlezen, juffrouw, want het wordt druk gevraagd; indien ik vele van dergelijke soort van boeken had, dan werd ik spoedig rijk."

(Van Zonneveld 1990, geciteerd in Van Gorp 1999, p. 193)

Voor de afwezigheid van gotieke romans van Nederlandse makelij zijn verschillende verklaringen gegeven, tot en met klimatologische aan toe. ${ }^{39}$ Volgens Van Gorp was een belangrijk punt dat de Middeleeuwen hier - voor de Noordelijke Nederlanden in elk geval - minder geschikt waren als legitimatie van de eigen grootheid (voor de Zuidelijke Nederlanden lag dat anders). Bovendien bestond de angst dat de Middeleeuwen teveel katholicisme als verhaalstof bevatte. Auteurs als Potgieter en Bakhuizen van den Brink bevalen de calvinistische zeventiende eeuw als geschiktere periode aan. De waardering die er soms wel bestond

\footnotetext{
${ }^{39}$ Bij gebrek aan woeste berglandschappen zou Nederland zich niet lenen voor de gothic novel, aldus tijdgenoten De willekeur van zo'n argument blijkt uit een vergelijking met de situatie in de Verenigde Staten. Henry James beschreef in een beroemd citaat over Hawthorne wat Amerikaane schrijvers ontbeerden aan materiaal: '[...] no aristocracy, no church, no clergy, no army, no diplomatic service, no country gentlemen, no palaces, no castles, nor manors, nor old countryhouses, nor parsonages, nor thatched cottages, nor ivied ruins; no cathedrals, nor abbeys, nor little Norman churches [...]' (James geciteerd in Gard 1987, p 133); kortom al die elementen waaruit de gotieke roman naar hartelust put. Dat verhinderde toch niet het ontstaan van een American Gothic-traditie, waarvan James een belangrijke vertegenwoordiger zou worden, samen met o.a. Charles Brockden Brown, de genoemde Hawthorne en Edgar Allan Poe.
} 
voor de zeer antikatholieke Engelse gothic novel werd getemperd door het 'extreme karakter' van die romans. De combinatie van de eis van zedelijkheid (en dus een rem op de 'teugelloze verbeelding') en een voorkeur voor de zeventiende eeuw verhinderden de doorbraak van een Nederlandse variant van de gothic novel, aldus Van Gorp.

De organisatie van het Nederlandse literaire leven in (a-commerciële) leesgezelschappen leidde volgens hem bovendien tot een conservatievere uitgeefpolitiek dan in Groot-Brittannië met sterkere ethische overwegingen. ${ }^{40}$ Ook Buikema en Wesseling (2006) wijzen op het belang van die genootschappen, die de nadruk legden op de beschavende, stichtende functie van literatuur, en de bewerking van bijbels materiaal stimuleerden. Een als immoreel en huiveringwekkend ervaren genre als de gotieke roman paste daar slecht bij. ${ }^{41} \mathrm{Zij}$ voegen daaraan toe dat Nederland eerder verstedelijkte dan omringende landen, wat onder meer betekende dat de burgerij al in de zeventiende eeuw een stevige positie verwierf. Daardoor ontstond niet zo'n scherp klassenconflict tussen adel en opkomende middenklasse als in Groot-Brittannië, wat een belangrijk thema is in de Britse gothic novels.

Dat er nauwelijks gotieke romans geschreven werden in Nederland, betekent zoals reeds gezegd niet a priori dat ze niet gelezen of bediscussieerd werden. Het bovennatuurlijke, een thema waar de 'schrikromans' in grossierden, hield de gemoederen rond 1800 bezig, zo blijkt bijvoorbeeld uit een prijsvraag van de Maatschappij "Tot Nut van het Algemeen" in 1799. Omdat men constateerde dat 'Duivelsbezweeringen, toveryen en Spookeryen' nog niet overwonnen waren, verzocht men om een betoog waarin 'het ongegronde, het onzedelyke, en het schaadlyke van deeze en andere hier mede verbondene Vooroordeelen worden aangetoond' (geciteerd in Van Gorp 1999, 189). Deze oproep werd nota bene geplaatst in de zesdelige (vertaalde) uitgave Spookeryen. Korte vertellingen uit het Ryk der Waarheid (1798-1803) van S.C. Wagener.

Het gotieke was eind achttiende, begin negentiende eeuw een cultureel fenomeen waarmee Nederlandse auteurs en lezers vertrouwd waren. Men kende auteurs en gotiek repertoire uit de vele vertalingen en later sporadisch uit werk van Nederlandse schrijvers. Naar de populariteit van het gotieke in latere periodes - de tweede helft van de negentiende eeuw en begin twintigste eeuw is wei-

${ }^{40}$ Van Gorp verwijst naar Kloek \& Mijnhardt (1990, p.117-118). Kloek noemt de (noord)Nederlandse dichtgenootschappen elders 'bolwerken van het verlichte burgerideaal' (Kloek, 2005, 12).

${ }^{41}$ Buikema en Wesseling verwijzen naar De Vries Beschaven! (2001) en Singeling Gezellige schrijvers (1991). 
nig onderzoek gedaan. De tweede helft van de negentiende eeuw vieren realisme en naturalisme hoogtij in Nederland en Vlaanderen (Schouten 1997, 22). Dan zien we volgens hem wel elementen van het macabere, morbide, en aan het begin van de twintigste eeuw het occulte en magische verschijnen, maar 'echte' griezelliteratuur kan hij niet ontwaren tot F. Bordewijk met zijn fantastische verhalen op het toneel verschijnt. Schouten beschouwt Belcampo als de enige in Nederland die het genre vlak na de Tweede Wereldoorlog 'draagt' (Schouten 1997, 22). Buikema en Wesseling (2006) voegen daar dus auteurs als Hermans, Haasse en Reve aan toe, gevolgd door Ruebsamen, Dorrestein en Franke. Ook de twee bloemlezingen oorspronkelijke Nederlandse griezelverhalen die RobertHenk Zuidinga $(1984,1986)$ samenstelde verdienen hier vermelding.

\section{DE BESTUDERING VAN HET GOTIEKE, GENDER EN QUEER}

Bij mijn keuze voor de romans die ik in dit boek analyseer heb ik een zeker evenwicht nagestreefd tussen mannelijke en vrouwelijke auteurs. Per roman stel ik specifieke elementen centraal van de snelle moderniseringsgolf die Nederland doormaakte. De belangrijkste zijn de seksuele revolutie, de tweede feministische golf en de homo-emancipatie; en met name de gevolgen van die processen voor opvattingen van mannelijkheid en vrouwelijkheid. Daarnaast komen ook thema's als klassenverhoudingen en secularisatie aan bod. Dat is meteen de kortste manier om dit boek in te delen: in de eerste drie romananalyses is mannelijkheid een centraal onderwerp, in de volgende drie vrouwelijkheid.

Een belangrijk nadeel van Mighalls boek is dat hij gender als categorie expliciet buiten beschouwing laat, met het argument dat 'questions of gender are, if not explicitly psychological, then premised largely upon ontological considerations (the issue of 'subjectivity)' (Mighall 1999, xxi). Hij miskent daarmee de dynamiek van het genderbegrip en negeert bovendien een groot corpus secundaire literatuur. Betekenissen van gender en seksualiteit zijn historisch veranderlijk. Sekseverhoudingen, (machts)verhoudingen tussen de seksen en definities van mannelijkheid en vrouwelijkheid zijn historisch gezien juist brandpunten in discussies over moderniteit. Een recent voorbeeld daarvan is het integratiedebat dat Nederland sinds het begin van de eenentwintigste eeuw in zijn greep heeft. (De acceptatie van) vrouwen- en homo-emancipatie vormt in die discussie vaak de toetssteen voor 'modern zijn'. ${ }^{42}$

\footnotetext{
42 Zie voor een analyse van dit fenomeen Mak (2007), die in dit verband de term 'a whiggish interpretation of Dutch history' gebruikt.
} 
Juist de culturele spanningen rond veranderende opvattingen over homoseksualiteit, mannelijkheid en vrouwelijkheid kunnen dus voer voor de gotieke verbeelding vormen. En juist die culturele spanningen wil ik bestuderen in laattwintigste-eeuwse Nederlandse romans. Vanaf het ontstaan van gothic studies is er wel veel aandacht geweest voor gender en seksualiteit. Omdat dit belangrijke thema's zijn in het kader van dit boek, schets ik in het kort de belangrijkste ontwikkelingen op dit terrein - eerst voor wat betreft gender en het gotieke, daarna voor zogenoemde queer gothic.

Tweede-golffeministen 'ontdekten' de gothic novel als een genre waarin vrouwen relatief belangrijk waren, als auteurs en als personages. Ze herkenden in de avonturen van gotieke heldinnen hun eigen feministische strijd voor de bevrijding van vrouwen. Literatuurwetenschapper Ellen Moers introduceerde in 1976 de term female gothic, waarmee ze doelde op 'the work that women writers have done in the literary mode that since the eighteenth century, we have called "the Gothic"(Moers 1976, 90). Ze wilde met die term niet alleen het werk afbakenen van schrijfsters die gotieke romans schreven, maar ze doelde ook op een volgens haar specifiek 'vrouwelijke' gotieke plot waarin een jonge heldin zich ontworstelt aan een schurkachtige vaderfiguur. De gotieke heldin, altijd net iets te nieuwsgierig voor haar eigen bestwil, werd een prototypische feministische figuur. De labyrintische gotieke landhuizen waarin de heldinnen ronddwaalden en blootgesteld werden aan gruwelijkheden en gevaar (Ann Radcliffe's A Sicilian Romance (1790) is het schoolvoorbeeld), werden door feministen gelezen als symbolen van het vrouw-onderdrukkende patriarchaat; en er leek geen beter arsenaal dan het gotieke denkbaar voor beklemmende beschrijvingen van het eigen afschrikwekkende (moeder-)lichaam. ${ }^{43}$

Tegelijkertijd leken deze heldinnen meer ruimte te krijgen voor ontwikkeling van hun subjectiviteit dan in andere literaire genres - ze maakten reizen en beleefden avonturen die in de huiselijke, realistische roman ondenkbaar waren. De gotieke roman zou daarom subversiever zijn dan de huiselijke roman. Het gotieke groeide in de feministische beeldvorming uit tot een strategie die vrouwelijke auteurs bij uitstek paste, temeer omdat de populaire, 'lage' gotiek werd afgezet tegen de door mannen gedomineerde, high-brow Romantiek. In de feministische zoektocht naar veronachtzaamde schrijfsters paste de gotiek wonderwel. Met andere woorden, vrouwen kregen een centrale rol toebedacht in de gotieke traditie, en het gotieke in de vrouwelijke literaire traditie. ${ }^{44}$

\footnotetext{
${ }^{43}$ Zie Moers (1978), die Frankenstein 'a horror story of maternity' noemt (p. 83).

${ }^{44}$ Zie voor een analyse van de gelijktijdige institutionalisering van genderstudies en gothic criticism Fitzgerald (2004). Er worden regelmatig overeenkomsten gesignaleerd tussen feministische en gotieke invalshoeken, zie bijvoorbeeld: 'it is this inherent fluidity and contradictoriness that
} 
Moers' nieuwe term luidde een productieve onderzoeksperiode in - er verschenen in de jaren tachtig en negentig talloze boeken en artikelen over vrouwelijke gotiek, in historische en hedendaagse literatuur. ${ }^{45}$ In de loop der jaren werden echter meer en meer kanttekeningen geplaatst bij de term female gothic. ${ }^{46}$ Robert Miles concludeerde in 1994 dat de term 'vrouwelijke gotiek' was versteend tot een essentialistische categorie, en dat feministische lezingen een impasse hadden bereikt, voornamelijk door de universalistische claims van veel psychoanalytische lezingen (Miles 1994). Miles pleitte niet zozeer voor het afschaffen van de term female gothic, maar voor onderzoek op meer materialistische leest (oftewel met meer aandacht voor de sociaal-historische context), voor een andere inzet van psychoanalytische methoden en voor vergelijkingen met zogenoemde male gothic. ${ }^{47}$ Inmiddels zijn er op het terrein van mannelijkheid en

ally postfeminism and Gothic in their mutual interrogation of binary structures and their "anxiety about "meaning"' (Brabon \& Genz 2007, 2). De abstractiegraad van zulke observaties maakt het wel eenvoudiger om zulke overeenkomsten te vinden.

${ }^{45}$ Tot de vroege publicaties over vrouwen en het gotieke behoren bijvoorbeeld Holland \& Sherman (1977), Wolff (1979), over vrouwelijke seksualiteit in het werk van Radcliffe, een inventarisatie van 'women's gothic' door Mussell (1981), en een eerste bundel essays (Fleenor 1983). Fleenor beschrijft gothic als een vrouwelijke vorm omdat het genre de vrouwelijke ervaring zou representeren (Fleenor 1983, 8). Kahane (1986) borduurt voort op Fleenors opvatting van het huis als gevangenis voor vrouwen. Modleski (1982) richt zich op massalectuur voor een vrouwelijk publiek: de populaire gothic romances uit de supermarkt. Overzichten te vinden in Miles (1994), Ellis (2000), Heiland (2004) en Smith en Wallace (2004). Voor Nederlandse toepassingen van een female gothic interpretatiekader, zie Kuiper (1992), Buikema (1995) en Hoekstra (1998, met name hoofdstuk 7). Zie ook Andeweg (2006). Dat gothic het nog altijd goed doet bij feministen blijkt bijvoorbeeld in het werk van feministisch filosoof Braidotti (2002), die stelt dat hedendaagse science fiction net als de gothic in de negentiende eeuw vrouwen in staat stelt 'to play active roles as travellers, murderesses, thieves, adventuresses of all sorts. That most Gothic heroines are eminently wicked is also a tribute to their intelligence and wit' (Braidotti 2002, 190).

${ }^{46}$ Ellis (1989) en DeLamotte (1990) wezen erop dat de happy ending van de vrouwelijke gothic novel eerder conservatieve dan subversieve effecten heeft. Clery (2000) stelde dat het lezen van de gothic in termen van familierelaties (heldin belaagd door vaderfiguur en op zoek naar afwezige moeder), en dus de identificatie van vrouwen met de privésfeer, ook conservatieve consequenties heeft. De huiselijke roman en de gotieke roman vertonen overeenkomsten in plotstructuur, beide zijn samen te vatten als 'damsel in distress'-plot (dat ik zou vertalen als vrouw-in-het-nauw plot). Lois Bueler noemt dit plot in de huiselijke roman het 'tested womanplot'. Zie Swinnen (2006, 40 e.v.) voor een bespreking van Bueler.

${ }^{47}$ Het begrip female gothic werd ook door anderen, op diverse manieren, genuanceerd. Uit analyses van het werk van Wilkie Collins, Charles Dickens en Joseph Sheridan LeFanu bleek dat mannelijke auteurs ook als 'vrouwelijk' aangeduide plots schreven (Heller 1992, Milbank 1992, 1994). Niet alle vrouwelijke auteurs schreven bovendien vrouwelijke plots, zo lieten Horner en Zlosnik zien in hun studie over Daphne du Maurier (1998). Verder bleken de (mannelijke) Romantiek en de (vrouwelijke) gothic niet altijd zo goed te scheiden (Gamer 2000). Naast de categorie female gothic ontstonden termen als gothic feminism (Hoeveler 1998), feminine gothic 
het gotieke vele titels verschenen. ${ }^{48}$ In hoofdstuk 5 en 6 kom ik terug op de discussie rondom female gothic.

Met name in de hoofdstukken 2, 3 en 4 maak ik gebruik van inzichten uit queer studies. Ik gebruik daarbij vooral het werk van literatuurwetenschapper en queer theorist Sedgwick. In haar boek Between Men (1985) verbindt ze de veranderende relaties tussen mannen met de opkomst van een bepaald type gothic novel en het ontstaan van een moderne homoseksuele identiteit. Sedgwick deed daarmee baanbrekend werk op het gebied van mannelijkheid en het gotieke, en stond ook aan de wieg van queer criticism. Met queer - een al even mobiele term als het gotieke - wordt de kritische praktijk bedoeld van het zichtbaar maken van de heteroseksuele norm. Met dat doel worden tegenstellingen ontleed die met name in seksuele definities/definities van seksualiteit gebruikt worden: heteroseksualiteit/homoseksualiteit, mannelijk/vrouwelijk, seks/gender, normaal/afwijkend. Gothic en queer laten zich goed combineren, en dat is niet toevallig aldus Bill Hughes en Andrew Smith (2009). ${ }^{49} \mathrm{Zij}$ stellen dat gotieke romans, al verkondigen ze uiteindelijk een conventionele (heteroseksuele) moraal, niettemin de grenzen van die moraal bevragen, en dat is een typische queer move.

\section{DE OPZET VAN DIT BOEK}

In de volgende hoofdstukken analyseer ik in detail zes Nederlandse romans waarin het gotieke verschijnt. Ik heb romans gekozen die ik boeiend vond om te analyseren. Ik heb geen ontwikkeling willen suggereren, daarvoor is de periode van vijftien jaar te kort en het aantal auteurs te klein. Het moge inmiddels duidelijk zijn dat ik het gotieke ruim opvat. Het kan betekenen dat er intertekstuele verwijzingen naar klassieke gotieke romans in te vinden zijn, dat de roman put uit het rijke repertoire van gotieke motieven (spoken, vampiers, verlaten huizen, familiegeheimen), dat die stilistisch het psychologisch-realisme ontstijgt, of dat het plot doet denken aan dat van een gothic novel - inclusief zijpaden,

(Becker 1999), women's gothic (Clery 2000) en lesbian gothic (Palmer 1999), alle met het doel om essentialisme te vermijden.

${ }^{48} \mathrm{Om}$ een aantal van de belangrijkste te noemen: Sedgwick (1985), Dijkstra (1986), Showalter (1990), Bronfen (1992), Hendershot (1998), Brinks (2003), Smith (2004).

${ }^{49}$ Voorbeelden van queer gothic studies: Sedgwick (1985, 1990), Castle (1993, 1995), Palmer (1999), Haggerty (2006), Hughes \& Smith (2009). 
melodramatische wendingen en onuitgewerkte personages. ${ }^{50} \mathrm{Bij}$ de interpretatie van al deze inhoudelijke en formele elementen is het mij steeds te doen om de vraag naar het culturele werk van de verschijning van het gotieke in een bepaalde roman..$^{51}$

Hoofdstuk 2 presenteert een lezing van Letter en Geest. Een spookverhaal (1982), van Frans Kellendonk. In Letter en Geest, zo zal ik betogen, wordt de frictie tussen oude en nieuwe homo-identiteiten via het gotieke verbeeld. Hoofdstuk 3 is gewijd aan het geweigerde boekenweekgeschenk van Gerard Reve, De vierde man (1981). In mijn analyse ga ik in op het gotieke als komische strategie, en op de vraag hoe Reve via het gotieke het (heteroseksuele) romantische plot ontmaskert. In hoofdstuk 4 staat Vriend van verdienste (1985) van Thomas Rosenboom centraal. Ik analyseer hoe die roman - gebaseerd op de beruchte 'Baarnse moordzaak' uit 1960 - grensoverschrijdingen op een gotieke manier verbeeldt, op het gebied van klasse, vriendschap en mannelijkheid. In hoofdstuk 5 analyseer ik twee romans van Renate Dorrestein, de ongekroonde koningin van de Nederlandse gotieke roman: Noorderzon (1986) en Het perpetuum mobile van de liefde (1988). Ik zal betogen dat in die romans het gotieke dient om spanningen rond feminisme, vrouwelijke seksuele autonomie, en individu versus gemeenschap vorm te geven. Ten slotte lees ik in hoofdstuk 6 Vonne van der Meers novelle Spookliefde (1995). Daarin zie ik verschijningen van het gotieke die te maken hebben met vrouwelijke seksualiteit en een verlangen naar het transcendente. Net als in het hoofdstuk over De vierde man is in de romans van Dorrestein en Van der Meer het romantische plot belangrijk.

Niet al deze romans zijn griezelig, voor zover zo'n oordeel ooit objectief te geven zou zijn..$^{52}$ Sommige zijn griezelig gewoon. De vierde man en Noorderzon

\footnotetext{
${ }^{50}$ De gotieke roman is kortom een goede kandidaat voor het 'sterke verhaal' waarvan Meeuse (1999) zich afvroeg waar ze gebleven zijn; verhalen waarin de handeling het belangrijkst is en personages niet zo uitgewerkt zijn. Zie ook Meijer (2006) over de terugkeer van melodrama in 'hoge' cultuur.

${ }^{51}$ Studies van Doorman (2004) en Van Kesteren (2004) hebben raakvlakken met mijn onderzoek. $\mathrm{Zij}$ laten de actualiteit zien van fenomenen waarmee het gotieke verwant is - respectievelijk de romantische orde en het verlangen naar de Middeleeuwen. Doorman onderzocht de blijvende invloed van wat hij de 'romantische orde' noemt, maar keek daarbij niet specifiek naar Nederland of naar literatuur. Van Kesteren deed een historische studie naar het verlangen naar de Middeleeuwen, maar afgezien van een enkele verwijzing naar Disneyland concentreerde hij zich op de negentiende-eeuwse versie van dat verlangen.

$52 \mathrm{Om}$ nog eenmaal terug te komen op Brakmans anekdote over het kijken naar Frankenstein: die laat zien dat angstgevoelens ook in één persoon historisch veranderlijk zijn. Wat hij in de jaren dertig griezelig vond, vond hij in de jaren zeventig saai. Dat kan liggen aan leeftijd van de beschouwer (wat het kind eng vindt, vindt de volwassene saai), of aan veranderde stijlconventies (griezelfilms moeten heel wat sneller gemonteerd worden willen ze nog effect sorteren), maar ook
} 
zijn zelfs komisch te noemen. ${ }^{53}$ Zelf vond ik Vriend van verdienste de meest gruwelijke roman - voor de duidelijkheid, dat is geen kwaliteitsoordeel, maar een belevingsoordeel. Het feit dat sommige romans bij verschijnen niet gotiek werden genoemd, zegt naar mijn mening niet zozeer iets over de eigenschappen van die romans, maar meer over de beschikbaarheid van het gotieke interpretatiekader. ${ }^{54}$

Toen Willem Brakman zijn essay over de gothic novel schreef, in 1976, was er aan de universiteiten in binnen- en buitenland maar weinig serieuze belangstelling voor de gothic novel. Dat is tegenwoordig wel anders, vooral in de Angelsaksische context. ${ }^{55}$ Inmiddels is er een heel corpus gothic criticism, een International Gothic Association en een eigen tijdschrift (Gothic Studies), wat sommigen doet verzuchten dat klassieke gothic novels als Dracula 'have been read to the point of exhaustion' (Walker, 2002, 4), terwijl anderen zich beklagen over het feit dat studenten tegenwoordig eerder Dracula lezen tijdens hun studie dan Pamela of Adam Bede (Baldick \& Mighall, 2000, 210).

Via de Engelstalige academische aandacht is het gotieke perspectief ook doorgedrongen in de Nederlandse literatuurbeschouwing, en pas recent is ook 'hoge' literatuur object van onderzoek geworden, onder invloed van cultural studies. De opwaartse mobiliteit van het gotieke en de ontwaarding van de literatuur zijn misschien twee kanten van dezelfde medaille. De beschikbaarheid van een gotiek interpretatiekader voor 'hoge' literatuur is wellicht terug te voeren op het afnemende gewicht van de literatuur. Als literatuur niet meer als de voorhoede wordt beschouwd in maatschappelijke kwesties, komt er ruimte voor het gotieke.

aan de veranderde historische situatie (na de oorlog kan Frankenstein geen angst meer aanjagen). Joanna Bourke (2005) geeft in haar culturele geschiedenis van de angst talloze voorbeelden van de historische bepaaldheid van angst.

${ }^{53}$ Horner \& Zlosnik (2005) hebben overigens laten zien dat het gotieke en het komische heel goed samen kunnen gaan, zie ook hoofdstuk 4.

${ }^{54}$ Vergelijk Meijer (1988), die een lesbisch interpretatiekader introduceert, waarbij ze aanmerkt dat het lesbische niet exclusief als een teksteigenschap moet worden opgevat, maar als een leeswijze (246-250). Overigens toonden sommige recensenten wel een zekere sensibiliteit voor het gotieke: Ab Visser die in de jaren zeventig voor de Leeuwarder Courant schreef, Maarten 't Hart toen hij in de jaren tachtig voor NRC Handelsblad recenseerde, Robert-Henk Zuidinga in Vrij Nederland; tegenwoordig NRC Handelsblad criticus Pieter Steinz.

${ }^{55}$ Baanbrekende publicaties van Eve Sedgwick (1980) en David Punter (1980). Europese (continentale) gotiek krijgt de laatste jaren wel meer aandacht, zie bijvoorbeeld Simonis (2005) over Duitse, Hall (2005) over Duitse en Franse, en Billiani \& Sulis (2007) over Italiaanse gotieke romans. Horner (2002) over Russische, Duitse, Franse en Spaanse gotieke romans; Horner en Zlosnik (2008) over Brits-Franse invloeden over en weer. 
Aan het begin van dit hoofdstuk schreef ik al dat Nederland geen echte griezeltraditie kent. ${ }^{56}$ Dankzij het feit dat een gotiek interpretatiekader beschikbaar is geworden, kunnen we Nederlandse romans nu wel analyseren op verschijningen van het gotieke. Ik zie dat als een verrijking van het begrippenkader waarmee we Nederlandse romans kunnen interpreteren. Het gotieke stelt mij in staat om te lezen in de diepte, aan de hand van theorie. In mijn interpretaties zal ik steeds de balans tussen historisch geïnformeerde close readings en theorie proberen te bewaren. Het is tijd om te gaan lezen.

\footnotetext{
${ }^{56}$ Als teken van de groeiende belangstelling (en opwaartse mobiliteit) moge een bloemlezing van Nederlandse gotieke verhalen gelden die binnenkort zal verschijnen in de Feniksreeks, samengesteld door Erica van Boven \& Olf Praamstra.
} 



\section{2}

\section{HET SPOOK VAN DE HOMOSEKSUALITEIT Letter en Geest van Frans Kellendonk'}

Frans Kellendonk (1951-1990) is de literaire annalen ingegaan als een van de Revisor-schrijvers, die met een beroemd groepsportret op de Haagse Post van 10 september 1977 werden afgebeeld. Met onder anderen Oek de Jong, Doeschka Meijsing, Nicolaas Matsier en Dirk Ayelt Kooiman werd hij tot 'akademist' uitgeroepen, en de debatten over zijn literaire plaatsbepaling concentreren zich rond de vraag of hij een modernistische dan wel een postmoderne auteur genoemd moet worden. ${ }^{2}$ Er is ook een heel andere kijk op Kellendonk mogelijk: als gotieke auteur. Kellendonk geeft namelijk op allerlei momenten in zijn werk blijk van een affiniteit met het gotieke: in zijn vertalingen, in zijn essays en in zijn fictie. Kellendonk was opgeleid als anglist en hij maakte waarschijnlijk langs die weg kennis met de Engelse en Amerikaanse gotieke traditie. Zo vertaalde hij werk van Thomas de Quincey, die geregeld als gotieke auteur is bestudeerd. ${ }^{3}$ Ooit verkoos hij De Quincey zelfs tot zijn favoriete personage. ${ }^{4}$ Van Henry James, een van zijn andere favorieten, vertaalde Kellendonk onder meer het spookverhaal 'The Jolly Corner'. ${ }^{5}$ Daarin komt een spookachtige dubbelganger

\footnotetext{
${ }^{1}$ Eerdere versies van dit hoofdstuk verschenen als Andeweg (2007 en 2007a).

${ }^{2}$ Zie bijvoorbeeld Goedegebuure (2001), Bax (2002), Op de Weegh (2005).

${ }^{3}$ Zie bijvoorbeeld Sedgwick (1986), p. 37-96, Schmitt (1997), p. 46-76, Bridgwater (2004).

${ }^{4}$ Kellendonk vertaalde The English Mail-Coach en On Murder, Considered as One of the Fine Arts (vertaald als De Quincey 1983). Voor het favoriete personage, zie: 'Thomas de Quincey'. In: Het favoriete personage van vijfenzeventig Nederlandse schrijvers, dichters en uitgevers van A. Alberts tot Ad Zuiderent. Amsterdam: Raamgracht, 1983, 57-58.

${ }^{5}$ Die vertaling verscheen in de bundel Transatlantische vertellingen (1983), waarin ook vertalingen van 'The Pupil' en 'Pandora' verschenen.
} 
van de hoofdpersoon voor, wel enigszins vergelijkbaar met die in Letter en Geest. Een spookverhaal. Deze roman van Kellendonk verscheen in 1982 en staat in dit hoofdstuk centraal.

Een ander spookverhaal van James vormt anwijsbaar een inspiratie voor Letter en Geest. Laurens van Krevelen, Kellendonks uitgever, beschrijft de regelmatige ontmoetingen die hij begin jaren tachtig had met Kellendonk en Ernst Braches. Braches schreef een boek over James' beroemdste spookverhaal The Turn of the Screw (1898) - in de tijd dat Kellendonk aan Letter en Geest werkte (Braches 1983). Kellendonk schreef een voorwoord bij dat boek. Van Krevelen schrijft dat Letter en Geest 'ongetwijfeld mede geïnspireerd [is] door de duizelingwekkende verteltechniek van James' (Van Krevelen 1998, 86). In Letter en Geest klinken inderdaad echo's van de thema's die Braches in zijn boek Engel en afgrond bespreekt. Er zijn bijvoorbeeld opvallende overeenkomsten tussen de positie van Kellendonks hoofdpersoon Felix Mandaat en die van de gouvernante in James' verhaal. Elders, in een essay waarin The Turn of the Screw ook aan de orde komt, stelt Kellendonk dat James' werk draait om 'het probleem van de kennis' (Kellendonk 1992, 750). ${ }^{6} \mathrm{Hij}$ wijst op de vele metaforen van (schilderij)lijsten en kooien waarmee dat probleem wordt verbeeld. The Turn of the Screw noemt hij een 'val voor de lezer' (761), omdat die steeds een nieuwe 'lijst' binnenstapt waaruit geen ontsnapping mogelijk blijkt.' In mijn analyse van Letter en Geest zal het 'probleem van de kennis' een prominente plaats innemen.

Ook over de verhalen van de Nederlandse auteur F. Bordewijk schreef Kellendonk een essay. In een poging Bordewijks surrealistische verhalen van een passend etiket te voorzien, gebruikt Kellendonk het begrip gotiek, zij het dat hij de term in architectonische zin opvat:

Barok, expressionisme, nieuwe zakelijkheid - die benamingen zijn ofwel te vaag, of verkeerd. Ik wil er wel een aan toevoegen, een architectonische: gotiek. Het proza van die verhalen heeft alle eigenschappen die door John Ruskin als noodzakelijke kenmerken van de gotiek zijn opgesomd: het is woest, grillig, werkelijkheidslievend, grotesk, weerbarstig, uitbundig. (Kellendonk 1992, 727)

\footnotetext{
${ }^{6}$ Overige citaten uit het werk van Kellendonk via paginanummers in de tekst.

${ }^{7}$ The Turn of the Screw (1898) is een driedubbel ingebed verhaal: een ik-verteller vertelt over een zekere Douglas, die een verhaal vertelt dat hem door een gouvernante is overgeleverd. Het verhaal eindigt op het niveau van de gouvernante, de lezer keert nooit meer terug op het niveau van de raamvertelling. Zie Felman (1982) voor een prachtige, gedetailleerde interpretatie van dit verhaal.
} 
In hetzelfde essay geeft Kellendonk in bondige bewoordingen zijn visie op het verschil tussen humor en horror. Beide draaien om het verwisselen van bezield en onbezield, aldus Kellendonk, maar het verschil is dat die verwisseling bij humor van buitenaf wordt waargenomen, en bij horror van binnenuit: 'Mechanische monsters, golems, het schepsel van Frankenstein, zijn griezelig omdat ze ons voorhouden dat ook wij maar machines zijn en zo de ziel ontkennen' (740).

Kellendonks belangstelling voor het gotieke blijkt ten slotte ook in zijn fictie. Er zijn diverse gotieke elementen in zijn verhalen en romans aan te wijzen. De setting van Bouwval is bijvoorbeeld typisch gotiek te noemen in de manier waarop het lot van huis en familie uiteindelijk samenvallen. ${ }^{8}$ Grootvaders villa is 'een betorend negentiende-eeuws bouwwerkje' (32) waarvan het houtwerk 'spookachtig' (33) afsteekt tegen het landschap. Het huis symboliseert de familietraditie die op het punt staat afgebroken te worden: het is verkocht en zal worden verbouwd tot showroom. In het verhaal 'De verheerlijking' vinden spiritistische seances plaats, en in 'Dood en leven van Thomas Chatterton', voert Kellendonk Horace Walpole op als spreker, de schrijver van de eerste gothic novel. ${ }^{9}$ Mystiek lichaam ten slotte gebruikt diverse elementen uit de gotieke beeldtaal: Prul heeft na een abortus haar 'spookje', de zieke jongen bezoekt 'Klein-Transsylvanië' voor bloedtransfusies en Broer noemt zichzelf 'een Frankenstein in het seksuele' (388).

In dit hoofdstuk beperk ik me tot de roman die in de ondertitel expliciet verwijst naar een spookverhaal: Kellendonks derde roman Letter en Geest (1982). In navolging van Julia Briggs, die enkele studies over het Engelse spookverhaal schreef $(1977,2000)$, beschouw ik het spookverhaal als een specifieke vorm van gotieke literatuur. Dat is niet ongebruikelijk, al kent de wereldliteratuur vele verhalen met spoken, ook van vóór het ontstaan van de gotieke roman. Volgens Briggs is het spookverhaal tussen pakweg 1830 en 1930 een van de dominante media voor verbeeldingen van het gotieke: na het verdwijnen van de eerste hausse gothic novels (meestal wordt Maturins Melmoth the Wan-

\footnotetext{
${ }^{8}$ Dat 'Bouwval' een gotieke titel is moge ook blijken uit het feit dat Ann Radcliffe's A Sicilian Romance in het Nederlands verscheen als De Bouwval, of de geschiedenis van de Marquisin van Mazzini (1793). Op dit punt is de roman vergelijkbaar met Vriend van verdienste (zie hoofdstuk 4).

9 Thomas Chatterton schreef 'middeleeuwse' gedichten onder de naam Rowley, die hij aan Walpole stuurde om uit te geven. Walpole reageerde in eerste instantie welwillend, maar wees Chatterton af nadat collega-dichters Thomas Gray en William Mason de gedichten als vervalsingen hadden herkend. Hoewel het verhaal dat Chatterton zelfmoord pleegde na Walpoles afwijzing hardnekkig is (zie bijvoorbeeld Mathijsen 2004, 10), houdt de Oxford Encyclopedia of British Literature het erop dat Chatterton stierf aan een overdosis arsenicum en opium, op zeventienjarige leeftijd, overigens nadat hij meer dan dertig stukken in tijdschriften gepubliceerd kreeg.
} 
derer (1820) als een van de laatste beschouwd), tot het moment dat andere media als radio(hoorspel) en film belangrijke vehikels voor het gotieke worden. Sindsdien worden spookverhalen als een vanzelfsprekend onderdeel van gotieke fictie beschouwd.

De genreaanduiding 'spookverhaal' vormt het startpunt voor mijn analyse, maar zoals zal blijken zijn er meer gotieke elementen in de roman die om een interpretatie vragen. Vervolgens vraag ik me af hoe de verschijningen van het gotieke in deze roman aan het eind van de twintigste eeuw geduid kunnen worden. Dat is een vraag naar verbanden met de historische en maatschappelijke context waarin deze roman verschijnt. Uitgaande van de veronderstelling dat het gotieke een manier is om ambivalenties rondom processen van modernisering te verbeelden (Mighall 1999), vraag ik me af welke moderniserings- of emancipatieprocessen hier frictie veroorzaken.

Letter en Geest wordt niet door één anachronisme gestructureerd, één duidelijke misplaatsing van heden in verleden of andersom, wat volgens Mighall de voornaamste bron van het gotieke is. Zo is de verhaalsetting van Letter en Geest eigentijds, en zijn er op het eerste gezicht geen historisch 'misplaatste' personages. ${ }^{10}$ Wel zijn er diverse archaïsche elementen - om te beginnen de bibliotheek - die zorgen voor gotieke ontsporingen. Ik zal mijn interpretatie door die verschillende contrasten tussen modern en archaïsch laten leiden. Ik gebruik daarbij het werk van Eve Sedgwick. Zij geeft haar theorie over (heteroseksuele) mannelijkheid en de gotieke roman, die ik in het eerste hoofdstuk kort uiteenzette, een interessant vervolg dat bijzonder goed aansluit bij Letter en Geest. Historisch specifieke veranderingen in opvattingen over het verwerven van een seksuele identiteit worden bij Kellendonk op een gotieke manier verbeeld, zo blijkt. Gelezen als gothic laat Letter en Geest spanningen zien tussen privé en openbaar leven, die veroorzaakt worden door de vervagende grenzen tussen seksualiteit en werk. De ambivalenties spitsen zich toe op de kwestie van seksuele identiteit. De bron van alle spanningen lijkt te zijn wat Eve Sedgwick male homosexual panic heeft genoemd: de dreiging van perversie, de dreiging van het geperverteerd worden. Voordat ik mijn analyse start, vat ik de roman samen en bespreek ik kort eerdere interpretaties van Letter en Geest.

\footnotetext{
${ }^{10}$ Hoewel er in de roman geen jaartallen genoemd worden is de setting hedendaags - er is bijvoorbeeld een 'automatiseringscommissie' (210). De enige periodeaanduiding is 'naoorlogs' (206).
} 


\section{EERDERE INTERPRETATIES}

Letter en Geest bestrijkt drie maanden uit het leven van Felix Mandaat, die tegen de dertig loopt en daarom heeft besloten dat hij zijn leven maar eens met anderen moet gaan delen. Om dit doel te verwezenlijken solliciteert hij op een baan bij een universiteitsbibliotheek, waar hij de tijdelijk afwezige meneer Brugman zal vervangen. De bibliotheek is een stoffig instituut dat wordt beschreven in al zijn mogelijke karikaturen: de bureaucratische werkwijze, de excentrieke collega's, hun particuliere hobby's. Mandaat wordt verliefd op zijn (zwangere) assistente, mevrouw Qualing, maar maakt zijn verlangen naar haar nooit kenbaar. Het spook uit de titel verschijnt als Mandaat tijdens een avonddienst ronddwaalt in het Magazijn van de bibliotheek - ook wel de Kapel genoemd -, een acht verdiepingen tellend stalen labyrint vol boeken. ${ }^{11}$ Mandaat ziet daar het spook, zij het alleen van achteren. Pogingen om het spook in te halen mislukken. Hij neemt een collega - het directielid Van Uffel - op een avond mee om het spook te observeren. Het spook verschijnt niet, Van Uffel randt Mandaat aan, en het eind van het liedje is dat Mandaat de Kapel ontvlucht.

Mandaat slaagt er niet in deel te worden van de gemeenschap, hij blijft een buitenstaander. Zelfs als hij zich wel onderdeel voelt van de groep - tijdens de koffiepauze vertelt hij eenmaal een verhaal waarbij iedereen aan zijn lippen hangt - verliest hij zijn gezelschap omdat hij zijn verhaal geen passend einde weet te geven. Hij voelt steeds meer dat hij Brugman niet kan vervangen, en dat hij zelf ook geen plaats kan innemen. Hij neemt ontslag, al wordt hem de baan voor vast aangeboden.

Zo samengevat zou Letter en Geest een rechttoe-rechtaan verhaal kunnen lijken over de entree van een man in het openbare leven, het domein van betaald werk, en zijn falen. Maar evenmin als ander werk van Kellendonk laat deze roman zich lezen als een (psychologisch-)realistisch verhaal. Daarvoor hebben de personages om te beginnen veel te vervreemdende, allegorisch aan-

\footnotetext{
${ }^{11}$ Janus Linmans beschrijft hoe de Leidse Universiteitsbibliotheek, waar Kellendonk in 1979 drie maanden werkte, als inspiratiebron diende voor Letter en Geest. De naam van de conservator in de roman, Molhuysen, verwijst naar P.C. Molhuysen (1870-1944) die aan het begin van de twintigste eeuw een geschiedenis van de Leidse bibliotheek schreef, waaruit Kellendonk volgens Linmans putte voor zijn beschrijvingen van het gebouw: 'door terug te grijpen op een niet meer bestaande situatie creëert Kellendonk een perfect gothic decor. De eeuwenoude kapel, met zijn stalen geraamte waar in het donker voetstappen op de rammelende roosters weerkaatsten, is een ideale setting voor de spookverschijningen' (Linmans 2006, 19). Het toont het belang van architectonische noties voor Kellendonks herwerking van het gotieke.
} 
doende namen, zoals Schiettekatte, ${ }^{12}$ Brugman, Van den Kerckhove, en blijven zij te schimmig. De verhaallijn maakt een incoherente indruk: er gebeurt maar weinig en wat er gebeurt wordt voortijdig afgebroken. Verder is de interactie tussen personages onduidelijk, er wordt langs elkaar heen gepraat, waardoor je als lezer voortdurend het gevoel hebt dat het verhaal als los zand door je vingers glijdt. Sommige gebeurtenissen of zelfs hoofdstukken lijken geen enkele relatie met het plot te hebben, zoals het hoofdstuk 'Twee beschamende herinneringen'. Er is een vreemd ironische verteller, die in de wij-vorm spreekt, maar ook Mandaats gedachten blijkt te kunnen lezen en dan meer op een innerlijke voice-over lijkt. Gecombineerd met de vele bijbelse en literaire verwijzingen benadrukt dit de literariteit van het verhaal, de niet-referentialiteit. Letter en Geest laat de lezer die een spannend verhaal verwacht onbevredigd achter. Zelfs het spook lijkt niet in staat enige spanning in het verhaal te creëren.

Letter en Geest is eerder onderwerp van analyse geweest, zoals vrijwel alles wat Kellendonk geschreven heeft. ${ }^{13}$ Veel auteurs betrekken alle romans van Kellendonk in hun analyses: er bestaat een sterke neiging om Kellendonks oeuvre als één geheel, met één thematiek te lezen. De karakteriseringen van Kellendonks belangrijkste thema's zijn tamelijk eensluidend. Zo vat P. Kralt Kellendonks 'hoofdthema' samen als 'de onbekendheid en de onkenbaarheid van de realiteit' (Kralt 1988, 116), terwijl Bart Vervaeck (1993) in de verhalen van Kellendonk steeds dezelfde spiegeleffecten ziet. Goedegebuure noemt 'vrijwel het gehele oeuvre van Kellendonk [...] gesitueerd op de grens van de vertrouwde wereld en één van haar mogeliike spiegelwerelden' (Goedegebuure 1997, 120). Hij beschouwt Letter en Geest als een anticipatie op Mystiek lichaam:

Mevrouw Qualing is een voorafschaduwing van Magda Gijselhart, zoals Felix Mandaat dat is van Leendert. Net als de jonge Gijselhart voelt Mandaat dat hij geen deel heeft aan de door heteroseksuelen beheerste geschiedenis van het vlees. Allebei horen ze immers tot de aan de dood gewijde geschiedenis van de solitaire, narcistische en in laatste instantie ook homoseksuele man. Juist om aan het tegennatuurlijk isolement te ontsnappen had Mandaat zijn betrekking als bibliothecaris aanvaard [...]. (Goedegebuure 1997, 125)

\footnotetext{
12 Tijn Boon leest hierin een verbastering van Schattenkeinder uit Bordewijks Bint, 'het "vrouwmens" $[\ldots]$ dat niets liever doet dan boeken verscheuren - een engel der wrake, schrik van de bibliotheek' (Boon, 1998, 59).

${ }^{13}$ Zie Kralt (1988), Goedegebuure (1989, 1997), Vervaeck (1993), Bosboom (1994), Dewaide (1995), Oppelaar (1997), Boon (1998), Op de Weegh (2005), Linmans (2006).
} 
Ik vind het problematisch dat Letter en Geest in Goedegebuures weergave niet veel meer lijkt te zijn dan een prefiguratie van Mystiek lichaam. De verschillen tussen die romans zijn namelijk aanzienlijk: in setting, in stijl ${ }^{14}$, en juist op het punt van de homoseksualiteit. Bovenstaande kwalificaties gelden weliswaar voor Broer (Leendert Gijselhart) in Mystiek lichaam, maar de veronderstelling dat Mandaat homoseksueel is, is niet een gegeven, maar eerder een vraag die nog gesteld moet worden. ${ }^{15} \mathrm{Het}$ is waar dat Kellendonks drie laatste romans - De nietsnut (1979), Letter en Geest (1982) en Mystiek lichaam (1986) - door herhaalde zinnetjes met elkaar verbonden zijn, wat de suggestie van een doorgaand verhaal wekt. De eenheidsconventie, die nog versterkt wordt door Kellendonks vroege overlijden, en zijn eigen homoseksualiteit, ontneemt echter het zicht op de verschillen tussen de romans.

Terwijl er dus grote overeenstemming is over Kellendonks belangrijkste thema's, lopen de meningen opvallend genoeg juist uiteen als het over het spook in Letter en Geest gaat. Het spook is achtereenvolgens gelezen als de geest van Brugman, die op zijn beurt een abstracte God zou symboliseren (Goedegebuure 1989, 1997, Boon 1998), als het spiegelbeeld van Mandaat (Vervaeck 1993), of als zijn dubbelganger (Oppelaar 1997), terwijl een andere lezing weer stelt dat Van Uffel de dubbelganger van Mandaat is (Kralt 1988). Volgens Op de Weegh (2005) zou het spook de (niet-bestaande) gemeenschap representeren. Vervaeck noemt Mandaat zelf 'een geest zonder lichaam' (Vervaeck 1993, 353), om verschillende redenen: hij vervangt een andere schim, Brugman; hij verkiest het verlangen, oftewel het ideaalbeeld, boven fysiek contact; en hij werkt in een cerebrale, onlijfelijke instelling: de bibliotheek. Wat niet voor die visie pleit, is dat Mandaat ondanks zijn veronderstelde onlichamelijkheid zeer lichamelijke sensaties ervaart - hij heeft last van een hardnekkige erectie en komt klaar als hij mevrouw Qualing opvangt die van een tafel valt. Bovendien wordt ook zijn uiterlijk beschreven (hij is een knappe man): zo schimmig is hij dus niet. Angst voor lichamelijkheid - waarmee Mandaat volgens Vervaeck behept is - is niet hetzelfde als onlichamelijk zijn.

\footnotetext{
${ }^{14}$ Goedkoop verwoordt de tegenstelling in stijl en inzet tussen beide romans als volgt: 'Met [...] Letter en Geest leek hij zijn open blik op de buitenwereld te verliezen en gevangen te raken in een meer en meer verliteratuurde binnenwereld. [...] [I]n Mystiek lichaam trok hij [...] de gordijnen van de leeszaal open om een nieuwe blik naar buiten te werpen.' (Goedkoop 2004, 50).

${ }^{15}$ In de Homo-encyclopedie van Nederland wordt Felix Mandaat een 'vereenzaamde homoseksuele bibliothecaris' genoemd (Bartels en Versteegen 2005, 105). Linmans schrijft juist expliciet dat Mandaat niet homoseksueel is: 'Mandaat, die geen homoseksueel is' (Linmans 2006, 11) en: 'Het is op het eerste gezicht merkwaardig dat Kellendonk zijn homoseksualiteit niet projecteert op Mandaat, zijn alter ego' (Linmans 2006, 30).
} 
Boon kiest net als Goedegebuure een religieus interpretatiekader en leest het spook als 'godvormige leemte' (Boon 1998, 102) die Brugman heeft achtergelaten. Goedegebuure interpreteert het spook als de abstracte God uit het Johannesevangelie, de God die het Woord is. Gevangen in de bibliotheek is dit levende Woord verworden tot dode letter, die alleen de liefde weer tot leven kan brengen. De titel Letter en Geest interpreteert Goedegebuure dan ook religieus, onder verwijzing naar Paulus' tweede brief aan de Corinthiërs: 'Want de letter doodt, maar de Geest maakt levend' (2 Cor 3:6). ${ }^{16}$ De ondertitel 'spookverhaal' is volgens Goedegebuure:

behalve genre-aanduiding ook de uitdrukking van een levensbeschouwelijk en literair programma waarin het geloof in een bovennatuurlijke wereld op één lijn komt te staan met het begoocheld zijn door hersenschimmen. Welke twintigste-eeuwer, zo suggereert Kellendonk bij wijze van vraag, zou spook- en bijbelverhalen nog serieus kunnen nemen? Horen ze niet thuis in de folklore van pret- en reliparken als de Efteling en de Heilige Landstichting? (Goedegebuure 1997, 123). ${ }^{17}$

Goedegebuure leest 'spookverhaal' dus als genre-aanduiding (hoewel hij verder weinig met die aanduiding doet) en als poëticaal statement. Kellendonk zou vraagtekens stellen bij de geloofwaardigheid van zowel spook- als bijbelverhalen.

Het idee dat spookverhalen eigenlijk niet (meer) serieus te nemen zijn, viel ook te beluisteren bij verschijning van de roman in 1982. Verschillende recensenten voelden kennelijk de noodzaak om het serieuze karakter van Kellendonks spookverhaal te benadrukken. Reinjan Mulder schreef: '[De ondertitel] zou associaties kunnen wekken met de negentiende-eeuwse griezelverhalen, die hun kracht voor een deel ontleenden aan inmiddels vrijwel verdwenen angsten en taboes. Een traditioneel spookverhaal zou nu makkelijk de lachlust opwekken. Letter en Geest doet dat echter niet' (Mulder 1982). En Hans Warren stelde: 'Een echt ouderwets spookverhaal valt vandaag de dag

\footnotetext{
${ }^{16}$ Goedegebuure leest Letter en Geest (en ook Mystiek lichaam) dus heel allegorisch. Ernst van Alphen (1993) maakt juist tegen die allegorische leeswijze bezwaar en betoogt dat Kellendonk zelf in Mystiek lichaam het allegorisch denken aan de kaak stelt.

${ }^{17}$ De vergelijking met het sprookjespark de Efteling keert terug bij Hans Goedkoop, die naar aanleiding van Kellendonks uitspraak 'Zet maar eens een kathedraal neer met z'n allen' schrijft: 'in mijn hoofd ontstond een beeld van een enorme bouwplaats met een onvoltooide Gaudikerk en een Efteling rondom'; waarop hij concludeert: 'Het sloeg nergens op in onze wereld' (Goedkoop 2004, 55). In beide gevallen staat de Efteling voor het ongeloofwaardige karakter van resp. de genre-aanduiding 'spookverhaal' en de concretisering van het verlangen naar gemeenschap.
} 
nauwelijks meer te schrijven, maar de manier waarop het spookelement in Letter en Geest ingevlochten werd is anvaardbaar' (Warren 1982). Ook Arnold Heumakers markeert de scheiding tussen traditioneel spookverhaal en moderne roman: [...] inderdaad, er komt een heus spook in voor, al is het bepaald niet zo dat Kellendonk klakkeloos in het voetspoor heeft willen treden van zijn vooral Engelse - voorgangers in dit huiveringwekkende genre. Een traditioneel spookverhaal is zijn boek allerminst, maar evenmin een parodie of pastiche.' (Heumakers 1982). De opluchting dat Letter en Geest een 'serieuze' roman is, en geen ouderwets spookverhaal is haast voelbaar. Die opluchting is veelzeggend: zij zegt iets over de verwachtingen die recensenten in 1982 van romans hebben. Romans moeten kennelijk op de een of andere manier modern zijn; let op woorden als 'nu', 'inmiddels' en 'vandaag de dag', waarmee het heden van het verleden wordt gescheiden. Voor bovennatuurlijke elementen is in een twintigste-eeuwse roman, zo bevestigt Goedegebuure nog eens ten overvloede, niet zomaar plaats.

Wim Oppelaar (1997) is de enige die het genre van het spookverhaal expliciet betrekt in zijn analyse van de roman. Mandaats falen zou te verklaren zijn uit de conventies van het spookverhaal: daarin is volgens hem vaak een held te vinden die mislukt. Het spook leest hij als een externalisering van Mandaats mentale processen, het spook is bij Oppelaar dus een verdubbeling van Mandaat. Bovendien markeert het de verschillende manieren waarop de personages omgaan met het onbekende - Mandaat beschouwt het spook als een empirisch feit, Van Uffel beschouwt het als een aberratie van Mandaats geest. Oppelaars conclusie is tautologisch: Mandaat zou zijn baan in de bibliotheek verlaten omdat hij geen sociale identiteit weet te verwerven, maar dat komt mijns inziens op hetzelfde neer. Overigens merkt hij op dat het genre van de gothic Kellendonk goed ligt omdat het niet-referentiële, niet-realistische karakter ervan goed past bij Kellendonks poëtica. Dat sluit weer aan bij Goedegebuures interpretatie van de ondertitel als genre-aanduiding en poëticaal statement.

Ik denk dat een gotiek interpretatiekader nieuw licht op Letter en Geest kan werpen, waardoor de eenheidsconventie, de neiging om in Kellendonks oeuvre steeds dezelfde betekenissen te lezen, wordt doorbroken. Hopelijk kan een gotieke lezing ook iets verduidelijken over het spook - de meningen lopen nu wel erg uiteen. Hoewel ik de recensenten die Letter en Geest geen 'echt' spookverhaal vonden begrijp, denk ik dat het verhelderend is om preciezer te kijken hoe en waar dit twintigste-eeuwse spookverhaal afwijkt van zijn voorgangers. Bovendien denk ik dat een gotiek interpretatiekader nieuwe inzichten kan bieden op een punt dat in nagenoeg alle interpretaties onbesproken blijft: de betekenis 
van het hoofdstuk 'Twee beschamende herinneringen', dat een vreemde eend in de bijt lijkt. ${ }^{18}$

\section{SPOKEN ZIEN}

Zoals gezegd begin ik mijn interpretatie van het gotieke in Letter en Geest met het spook. Gewoonlijk vormt de verschijning van een spook een narrative drive in het verhaal, die beslissende gevolgen heeft voor het plot. Ondanks de genreaanduiding 'spookverhaal' in de ondertitel lijkt het spook in Letter en Geest een zeer marginale rol te spelen. Er is in feite maar één scène waarin het verschijnt, en die neemt welgeteld twee pagina's in beslag. Het is niet bepaald een angstaanjagende episode, noch voor de lezer, noch voor de enige getuige van het spook: Mandaat. Het spook manifesteert zich tijdens een avonddienst in de Kapel als 'een ritme zonder geluid' (230), dat Mandaat herkent als 'het loopritme van een volwassen man' (230). Hij is geschrokken maar ook opgewonden, en probeert het geluid te naderen. Als hij een glimp opvangt van een 'vluchtige gestalte' (231), achtervolgt hij deze, 'een mannengestalte, recht van postuur, met een kalme, krachtige tred' (231). Meer dan de rug van het spook krijgt hij echter niet te zien. Mandaat voelt behalve een dreiging van gevaar ook vreugde, die begint te tanen als hij er niet in slaagt dichterbij het spook te komen. 'Hij port zichzelf aan: "Een spook, dit is een spook!"' (232) maar dat helpt niet: 'De ervaring wordt er niet opwindender door.' (232). Vervolgens schrikt Mandaat van zijn pieper die afgaat 'veel heviger dan daarnet' (232) van het spook. De 'ontmoeting' wordt daarmee ruw verstoord. Tijdens de volgende avonddienst laat het spook zich niet zien, maar bij een derde bezoek aan de Kapel 'was Mandaat blij om [...] andermaal [...] achter zijn spook aan te kunnen draven' (233). Veel meer dan dat hij het spook opnieuw niet weet te naderen wordt er niet over gezegd.

De ontmoetingen met het spook lijken al met al nauwelijks van belang voor het plot van Letter en geest. Hoe komt het dat het spook niet zorgt voor spanning in het verhaal? De belangrijkste reden is dat Mandaat de wetten van het spookverhaal naar zijn hand zet. De meest basale vraag die een spookverhaal opwerpt, volgens Julia Briggs, is: 'Was it real or imaginary?' (Briggs 1977, 22). Dat is in de eerste plaats een ontologische vraag - bestaat het spook of niet? De

\footnotetext{
${ }^{18}$ Linmans, die als enige een poging doet dit hoofdstuk te interpreteren, leest het als 'de beschrijving van twee verdrijvingen van de jonge Mandaat uit het paradijs' (Linmans 2006, 9). Op de Weegh (2005) noemt alleen de bijbelse verwijzing 'de dochter van de Farao' uit dit hoofdstuk, die zou impliceren dat Mandaat een soort Mozes is die in het riet langs de rivier gevonden wordt.
} 
onzekerheid over het bestaan van het spook is de voornaamste bron van spanning in het verhaal. Precies op dit punt wijkt Letter en Geest af van het traditionele spookverhaal. Als Mandaat het spook een tweede maal gezien heeft, concludeert hij: 'Het spook is daarmee, tenzij hij gek is, maar ach nee, dat is hij niet, tot een empirisch feit geworden en dus kan het haast niet anders of meer mensen hebben er weet van.' (233). Mandaat heeft het spook meer dan eens waargenomen en dus moet het wel bestaan, zo redeneert hij. De vraag 'was het echt of niet' gaat niet meer over het al dan niet bestaan van het object (het spook), maar over het waarnemende subject, Mandaat, en is daarmee een epistemologische vraag geworden. Een spook stelt met andere woorden niet alleen het probleem van het zijn of niet-zijn, maar ook het 'probleem van de kennis' (waar ik in het begin van dit hoofdstuk aan refereerde) centraal. ${ }^{19}$ Mandaat lost de ontologische onzekerheid over het spook onmiddellijk op door een eigen, particuliere epistemologie te ontwerpen, de regels voor wat als kennis geldt.

Mandaats redenering zal menig wetenschapsfilosoof de wenkbrauwen doen fronsen. Om te beginnen stelt hij vast wat waar is, wat ware kennis is, via het principe van verifieerbaarheid: hij bevestigt zijn eerste waarneming met een tweede. Volgens dat principe is een uitspraak waar als zij empirisch bevestigd kan worden. Volgens de positivistische filosoof Karl Popper kan verificatie echter nooit zekerheid verschaffen over de waarheid van een hypothese. Ware (wetenschappelijke) kennis kan alleen via falsificatie worden verkregen. ${ }^{20}$ Een andere eis aan ware kennis is intersubjectiviteit. Dat wil zeggen dat een hypothese ook toetsbaar moet zijn door anderen, anders geldt die niet als waar. Mandaat draait de zaak echter helemaal om. Hij gaat er vanuit dat meer mensen weet moeten hebben van het spook, omdat hijzelf het vaker dan een keer heeft gezien. Hij veronderstelt dus dat de kennis van het spook intersubjectief is omdat zijn waarneming bevestigd is (in plaats van gefalsifieerd) - door hemzelf nota bene, in plaats van door anderen. Dus de elementaire ontologische vraag die het spookverhaal opwerpt - was het spook echt of niet? - die normaliter een narrative drive vormt, wordt simpelweg beantwoord doordat Mandaat de regels voor

\footnotetext{
${ }^{19}$ Het belangrijkste verschil tussen modernisme en postmodernisme, zo vat Ernst van Alphen Brian McHale's standpunt samen, is dat modernisme, modernistische literatuur incluis, uitdrukking geeft aan een epistemologische problematiek, terwijl postmodernisme wordt gemotiveerd door een ontologische problematiek; het verschil tussen 'wat kan ik kennen' en 'wat is dit voor wereld' (Van Alphen 1989, 23-24). Van Alphen stelt dat epistemologische vragen omslaan in ontologische als ze ver genoeg doorgevoerd worden en vice versa. Een spookverschijning is typisch een fenomeen dat beide soorten vragen oproept. Wellicht is daardoor de veelbesproken vraag of Kellendonk modernistisch of postmodernistisch genoemd moet worden, zo moeilijk te beantwoorden (zie bijvoorbeeld Goedegebuure 2001, Bax 2001, 2002, Op de Weegh 2005).

${ }^{20}$ Zie Van Brakel \& Van den Brink (1988), p. 81-87.
} 
wat als kennis geldt naar zijn hand zet. De spookverschijning verliest zo al zijn potentiële spanning.

Het is niet zozeer de ontmoeting met het spook, maar veeleer het zwijgen over het spook dat van belang is voor het plot van Letter en Geest, het spook als mogelijk gespreksonderwerp. Mandaat voelt zich namelijk buitengesloten door zijn collega's, omdat niemand hem iets verteld heeft over het spook, terwijl hij heeft vastgesteld dat het haast niet anders kan dan dat anderen ervan weten. Dat is van groot belang voor Mandaat, omdat hij via zijn baan juist zijn leven met anderen wilde delen. Mandaat denkt dat zijn collega's het spook voor hem verzwijgen, net zoals ze zwijgen over Brugman, de man die hij vervangt. Daarom weer een voorbeeld van Mandaats eigenzinnige logica - verbindt hij de twee zaken met elkaar, en besluit dat het dus wel Brugmans geest moet zijn die hij heeft gezien.

De eenvoudigste definitie van een spookverhaal volgens Briggs is dat het gaat over de geest (of geesten) van een dode die terugkeert. Een ander kenmerkend element is dat bovennatuurlijke verschijnselen in spookverhalen meestal niet weggeredeneerd of verklaard worden, zoals bijvoorbeeld in de gothic novels van Ann Radcliffe (explained supernaturalism). De normale wetten van oorzaak en gevolg worden tijdelijk opgeschort in het spookverhaal en in plaats daarvan heerst er een alternatieve, eigen logica die de aanwezigheid van het spook moet verklaren:

The ghost story's 'explanations' do not operate to rationalise or demystify the supernatural events, but rather to set them inside a kind of imaginative logic [...] in which thought itself is a mode of power, in which wishes or fears can actually benefit or do harm. (Briggs 2000, 123)

Een voorbeeld van zo'n alternatieve logica is dat een geestesverschijning veroorzaakt wordt door een lijk dat nog niet begraven is, of door iemand die een onnatuurlijke dood gestorven is. Mandaat kent die spookverhaallogica wel, want hij denkt over Brugman: 'om hier rond te kunnen spoken moet hij overleden zijn, onder omstandigheden die alles te maken hebben met deze omgeving' (234). Toch is het niet duidelijk wiens geest er ronddwaalt, en ook niet of er eigenlijk wel iemand dood is. Als het directielid Van Uffel - de enige die Mandaat uiteindelijk in vertrouwen neemt - hem vraagt naar de identiteit van het spook, en en passant zijn vertrouwdheid met de gotieke verbeelding toont ('Is het misschien een non uit het voormalige klooster? Een vermoord kind? Ik noem maar wat...') (253) - zegt Mandaat dat hij denkt dat het Brugmans geest zou kunnen zijn. 'Brugman is toch niet dóód?' (253), zegt Van Uffel, waarop 
Mandaat uitlegt dat alles zou kloppen 'als het spook de geest van Brugman zou zijn' (253). Later in het verhaal wordt meegedeeld dat Brugman is overleden. Het lijkt er dus sterk op dat de gebeurtenissen in deze roman worden gevormd naar wat de hoofdpersoon denkt. Kellendonk herschrijft zo de wetten van het traditionele spookverhaal. De alternatieve logica die Briggs noodzakelijk acht voor het spookverhaal wordt in dit geval ter plekke verzonnen door de hoofdpersoon. Mandaat kan vaststellen dat het spook echt bestaat, en Mandaat kan oorzaak en gevolg omdraaien als hij denkt dat het wel de geest van Brugman moet zijn die rondwaart. Daarom gaat Brugman dood, verderop in het verhaal, want dat is wat past in Mandaats spookachtige logica. Beide herschrijvingen benadrukken Mandaats solipsistische karakter, dat een aantal malen genoemd wordt in Letter en Geest.

Er lijkt echter een kleine opening in Mandaats solipsistische universum te zijn. Ondanks zijn gebrek aan twijfel over het bestaan van het spook, besluit hij om zijn paranormale ontmoetingen 'op te biechten' (253) en een collega in vertrouwen te nemen. Mandaat vraagt het directielid Van Uffel om tijdens een avonddienst met hem mee te gaan naar het magazijn, om samen het spook af te wachten. In feite vraagt Mandaat Van Uffel om zijn waarnemingen te bevestigen, om het 'empirische feit' van het spook alsnog tot werkelijk intersubjectieve kennis te maken. ${ }^{21}$ Het is een poging om te ontsnappen aan zijn solipsisme, een poging om iets te delen - misschien niet zijn leven, maar dan toch minimaal een waarneming. Zo'n waarnemer van een experiment, zo'n getuige, heeft in de wetenschapsgeschiedenis sinds 1985 een naam: Shapin \& Schaffer (1985) doopten hem de modest witness. Deze bescheiden getuige is iemand wiens onbetrokken observatie cruciaal is voor de wetenschappelijke methode, waarbij experimentele waarnemingen worden geverifieerd. De Amerikaanse wetenschapsfilosoof Donna Haraway noemt de modest witness:

one of the founding virtues of what we call modernity. This is the virtue that guarantees that the modest witness is the legitimate and authorized ventriloquist for the object world, adding nothing from his mere opinions, from his biasing embodiment. And so he is endowed with the remarkable power to establish the facts. He bears witness: he is objective; he guarantees

\footnotetext{
${ }^{21}$ De werktitel voor Letter en Geest was 'De Waarnemer'. Die lijkt zeer van toepassing op deze scène, maar is tot nu toe vooral op Mandaat betrokken, naar aanleiding van Kellendonks uitspraak in een interview met Hervormd Nederland (1980): 'Een waarnemer is iemand die voor een ander invalt in een baan, maar die tegelijk ook observeert (geciteerd in Op de Weegh 2005, 252 noot 24, zie ook Linmans 2006, 17).
} 
the clarity and purity of objects. His subjectivity is his objectivity. (Haraway 1997, 24)

De bescheiden getuige moet als het ware onzichtbaar zijn, lichaamloos, hij is enkel het transportmiddel van de transcendente waarheid. De wetenschapper als objectieve modest witness is echter een mythe van de moderne, Europese wetenschap, en Haraway heeft ondertussen laten zien dat die wel degelijk gegenderd is.

Terug naar Letter en Geest. Mandaat en Van Uffel zien het spook die avond niet, oftewel de waarneming van het empirische feit wordt niet bevestigd. Daarmee wordt opnieuw een potentielle bron van gotieke spanning in het verhaal weggenomen. Dat kan een paar dingen betekenen: het spook bestaat niet (en Mandaat is dus toch gek); of het spook bestaat wel maar het verschijnt niet. Dan is het de vraag of dat toevallig is, of dat het niet verschijnt omdat Van Uffel erbij is. In dat laatste geval zou Van Uffel geen geschikte getuige zijn, omdat hij de waarneming beïnvloedt. Dan kan hij het ideaal van de modest witness niet belichamen - bijvoorbeeld omdat hij niet bescheiden of onbetrokken genoeg is. Ik wil pleiten voor die laatste interpretatie: dat Van Uffel een ongeschikte getuige is. Om dat idee verder te onderbouwen ga ik eerst nader in op de figuur Van Uffel en de avond die Mandaat en hij in de Kapel doorbrengen, via Sedgwicks opvattingen over de gotieke roman en homoseksuele identiteit.

\section{VRIJGEZELLEN}

Vergeleken met Mandaats ontmoeting met het spook is de avond met Van Uffel in de Kapel veel gotieker: angstaanjagender, over the top zelfs. Het is een langdurige scène van twee mannen die elkaar achterna zitten, die resulteert in een aanranding en zelfs (enig) geweld. Deze scène, die zo'n twaalf pagina's in beslag neemt en dus veel uitgebreider is dan de ontmoeting met het spook, heeft alle kenmerken van wat Eve Sedgwick paranoid gothic heeft genoemd: 'novels in which a male hero is in a close, usually murderous relation to another male figure, in some respects his "double", to whom he seems to be mentally transparent' (Sedgwick 1990, 186). Paranoïde gotieke plots eindigen altijd, zoals Frankenstein, 'in the tableau of two men chasing one another [...] toward a climax that tends to condense the amorous with the murderous in a representation of male rape' (Sedgwick 1990, 163). Zoals ik in het vorige hoofdstuk al aanstipte, stelt Sedgwick dat de paranoïde gotieke roman het literaire genre par 
excellence is waarin de opkomst van een moderne notie van (mannelijke) homoseksualiteit zichtbaar wordt gemaakt, en de spanningen die zo'n moderne notie met zich meebrengt (Sedgwick 1985, 1990).

Met het ontstaan van een homoseksuele identiteit werden alle relaties tussen mannen (uitgezonderd die tussen mannen die zichzelf expliciet identificeren en accepteren als homoseksueel) gereguleerd door male homosexual panic, zo stelt Sedgwick: de angst om homoseksueel te zijn of om als homoseksueel gezien te worden. De dreiging om homoseksueel (genoemd) te worden is altijd aanwezig, en vandaar de paranoia, aldus Sedgwick. Tegelijkertijd zijn nauwe banden met andere mannen - leraren, collega's, etcetera - nodig om een succesvolle man te worden. Om met mannelijke homoseksuele paniek om te gaan, en met de double bind van voorgeschreven en verboden relaties tussen mannen, zijn nieuwe literaire vormen nodig, waarin nieuwe taxonomieën van mannelijkheid worden ontwikkeld, in Sedgwicks woorden.

Zij ziet vanaf het midden van de negentiende eeuw een nieuw soort mannelijk personage ontstaan in wat zij samenvat als bachelor-literatuur. In die romans speelt een vrijgezel de hoofdrol en zijn vaak nog sporen van de paranoïde gotieke roman te vinden. Sedgwick ziet in deze negentiende-eeuwse vrijgezel een personage dat met homoseksuele paniek omgaat door seksualiteit in zijn geheel af te wijzen. ${ }^{22}$ Niet geschoten is in dit geval nooit mis - door geen seksuele partner te kiezen kiest de hoofdpersoon in ieder geval niet de verkeerde (een man). Sedgwick beschouwt de vrijgezellenliteratuur als een soort getemde gothic, 'in several senses a domestication' van het paranoïde gotieke plot (Sedgwick 1990, 189). ${ }^{23}$

Mijn stelling is dat we Felix Mandaat kunnen begrijpen als zo'n voortzetting van de paranoïde gotieke held. Door de aandacht te vestigen op Mandaats vrijgezelle staat wordt veel duidelijker waarom hij faalt. Wat brengt deze manifestatie van de domesticated paranoid gothic in Letter en Geest teweeg? De Nederlandse maatschappelijke context van 1982 is immers heel anders dan in de periode van bachelor-literatuur. Homoseksualiteit is weliswaar nog steeds een identiteit, maar de context is veel geëmancipeerder.

\footnotetext{
22 Voorbeelden die ze noemt zijn o.a. George Eliot 'The Lifted Veil' (1859), Robert Stevenson Jekyll and Hyde (1886), George Du Maurier Trilby (1894) en Henry James 'The Jolly Corner' (1908) - titels die in gothic criticism regelmatig voorkomen, zie bijvoorbeeld Horner \& Zlosnik (2005) (over Du Maurier), Savoy (1999) (over James), Goddu (1997) (over Eliot), Hendershot (1998) (over Stevenson).

${ }^{23}$ In die ontwikkeling proef ik een parallel met wat elders het ontstaan van 'homely gothic' is genoemd, zie Botting (1996), p. 113-134.
} 
Het wemelt van de vrijgezellen in Letter en Geest. Niet alleen Felix Mandaat is vrijgezel, datzelfde geldt voor Van Uffel en de afwezige Brugman himself, al laten ze daar op hun werk liever niets van merken. Er lijkt een strikte scheiding tussen hun privé- en hun publieke leven te zijn. Als Mandaat bijvoorbeeld probeert om Brugman op te bellen, ontdekt hij dat Brugman bij een hospita woont, wat niemand op de bibliotheek wist. Zelfs Brugmans directe assistente mevrouw Qualing, die vol van hem is en voortdurend hoog van zijn werk opgeeft, weet niet waar hij woont. Brugmans hospita vertelt Mandaat dat Brugman is vertrokken zonder adres achter te laten, omdat er niemand was die voor hem kon zorgen.

Ook Van Uffel laat op zijn werk liever niets van zijn privé-leven zien. Er lijkt er een strikte scheiding te bestaan tussen de privé-persoon Van Uffel en de professional: Mandaat ziet hem schichtig de bibliotheek binnenkomen als 'de privé-persoon Latour van Uffel' (207), met zijn druipende overschoenen in de hand. Pas na tien minuten komt hij uit zijn kamer tevoorschijn, nu 'als directielid, als "Van Uffel"' (208) - het eerste deel van zijn naam heeft hij dus met zijn overschoenen binnen achtergelaten. Mandaat merkt echter op dat 'de privépersoon Van Uffel terdege zijn sporen heeft nagelaten' (208) op het grijze kostuum van het directielid: het is bezaaid met de overblijfselen van zijn ontbijt. Mandaat concludeert: 'Er waait je uit die kleren een compleet vrijgezellenbestaan tegemoet' (208). Mandaat herkent Van Uffel, ondanks diens pogingen de privé-persoon achter zich te laten, dus onmiddellijk als vrijgezel. Dat is overigens wederzijds. Van Uffel noemt Mandaat op zijn eerste werkdag een van 'mijn broeders' (213). Hij vertelt Mandaat later nog eens dat hij hem onmiddellijk herkende: 'Ik wist wel dat jij ook zo'n solitair was. Al bij onze eerste ontmoeting zag ik dat we heel veel gemeen moesten hebben.' (254). Mandaat reageert op deze opmerking door snel de revers van zijn jasje af te kloppen. Dat kan alleen maar betekenen dat hij de mogelijke sporen van zijn eigen privépersoon, die hij bij Van Uffel zag zitten, wil verwijderen. Mandaat reageert alsof hij betrapt is, alsof hij het gevoel heeft dat Van Uffel zijn gedachten kan lezen. Deze uitwisseling herinnert aan Sedgwicks beschrijving van de gotieke held en zijn dubbelganger, die voor hem mentaal transparant is.

Mandaat probeert dus ook zijn vrijgezelle status te verbergen. Dat was al zo voordat hij zijn baan kreeg in de bibliotheek, maar toen liepen werk (als iets van de openbaarheid) en liefdesleven (als iets van de privé-sfeer) ernstig door elkaar. Mandaat organiseerde eerder congressen. Hij werkte vanuit huis, vanuit zijn bed om precies te zijn, de plaats die het meest de privé-sfeer symboliseert. Hij presenteerde zich altijd in een 'Siamees meervoud dat hij stug volhield' (205) als 'makelaars in evenementen' (205). Hij verliet zijn huis alleen tussen de middag 
en kocht altijd twee bolletjes bij de bakker en nooit minder dan twee biefstukken bij de slager, 'uit schaamte voor zijn eenzaamheid' (206). Die boodschappen wijzen niet op een eenzaamheid in het werk - ze wijzen op eenzaamheid in zijn privé-leven. Mandaat schaamde zich niet voor het feit dat hij alleen werkte, maar dat hij alleen woonde, oftewel voor het feit dat hij vrijgezel was.

Als hij op zoek gaat naar een baan, doet hij dat omdat hij vindt dat hij zijn leven maar eens met anderen moet gaan delen. Die uitdrukking - je leven delen - wordt gewoonlijk geassocieerd met het privé-leven, het liefdesleven. Overigens heeft Mandaat zijn leven wel eerder gedeeld met anderen: hij is op kostschool geweest, en hij heeft in dienst gezeten. Beide zijn gemeenschappen die juist bekend zijn om hun gebrek aan privacy, en het zijn allebei jongens- of mannengemeenschappen; klassieke literaire omgevingen voor het ontdekken van een homoseksuele identiteit. Een baan is de onvermijdelijke volgende stap volgens Mandaat, die zijn dertigste verjaardag voelt naderen. Dat Mandaat het zoeken van een baan met zijn leeftijd verbindt wijst erop dat hij dat als een rite de passage beschouwt, een ritueel om een volwassen man te worden dat vaak verbonden is met het bereiken van de volwassen seksualiteit. Zo beschouwd mag het een verrassing heten dat het hier gaat om een baan.

Mandaat ervaart zijn baan als het begin van 'zijn openbare leven' (204), en hij heeft het gevoel dat hij nu 'de geschiedenis' betreedt (209). Hij hoeft niet langer zelf de evenementen, de gebeurtenissen te organiseren, hij zal nu zelf onderdeel worden van de keten van gebeurtenissen die de geschiedenis vormen. Een baan zal hem deelgenoot maken van het moderne, productieve leven, en het werknemerschap biedt hem zelfs de entree tot een nieuw nationaal gevoel. Als hij zijn eerste reis als nieuwbakken forens maakt, wordt hij overvallen door een soort opwinding die weliswaar met enige ironie wordt verwoord, maar niettemin tastbaar is:

De trein heeft hem door een Nederland gevoerd dat hij nog niet kende. Een duisternis waartegen fabrieken en kantoren dapper hun lichten hebben opgestoken. [...] hij heeft gezien hoe de ramen van de trein besloegen door de meegebrachte nestwarmte. Werkend Nederland! Al deze treinreizigers hebben hun bezigheden. De een freest, draait, schaaft; de ander onderwijst en vergadert [...]. Wat Mandaat precies gaat doen weet hij nog niet. (204)

Mandaat steekt nog een beetje schamel af bij de productiviteit die zijn medereizigers lijken te bezitten, maar ook hij wil zich bewijzen als modern, daadkrachtig subject. Bij zijn aankomst in de bibliotheek wordt hij door de verteller, die 
namens het instituut in meervoudsvorm spreekt, inderdaad als moderne burger waargenomen:

$\mathrm{Nu}$ zit hij hier, in een van onze directiekamers, dit resultaat van verantwoorde voeding, medische en tandheelkundige zorg, van lager, middelbaar en wetenschappelijk onderwijs. In een paar decennia heeft naoorlogs Nederland iets geschapen dat in vroeger tijden generaties en fortuinen zou hebben gekost: een heer.' (206)

In naoorlogs Nederland is niet langer afkomst doorslaggevend voor je positie, maar opleiding. Mandaat is een moderne 'heer'; maar het instituut waar hij terechtkomt blijkt verre van modern. Maakte de gevel van de bibliotheek nog een 'indruk van orde en overzichtelijkheid' (208), binnen is het een doolhof van gebouwen en gangen met 'portretten die zwartgeblakerd zijn door het smeulen der eeuwen' (208). Bij de rondleiding krijgt Mandaat te horen dat aan de kamer van de bibliothecaris al honderd jaar niets is veranderd, 'het stro steekt aan alle kanten uit de crapaudtjes' (207). In deze atmosfeer van traditie en bureaucratie probeert Mandaat zichzelf te bewijzen als modern subject, en dat is geen eenvoudige opgave.

Voor iemand wiens naam naar zijn sekse (man) en naar actie (daad) verwijst, is Mandaat een behoorlijke mislukking. Hij is bepaald geen man van de daad (niet voor niets zegt Van Uffel hem dat hij gevangen zit in de eenzaamheid van de taal), en zeker niet de Daad met een hoofdletter. In het hoofdstuk 'Twee beschamende herinneringen' wordt de achtergrond van deze dadenloosheid verteld. Het is een flashback naar twee erotische ervaringen van Mandaat met vrouwen, waarin hij door de vrouw verleid wordt, en vervolgens wordt bekeken door een derde partij. De eerste herinnering is aan een ontmoeting met een zigeunervrouw bij de rivier. Hij voelt dat ze hem mee wil tronen en volgt haar verwachtingsvol een lege steenfabriek in, slechts in zwembroek gekleed. Maar ze blijken niet alleen te zijn: Mandaat wordt met steentjes bekogeld door een jongen die ook 'van haar soort' is (250), waarop hij wegvlucht 'terwijl de opwinding van zojuist uit hem wegsijpelde en alleen de zekerheid bleef dat hem nooit iets kon gebeuren' (250). Dat klinkt alsof hij tamelijk onaangedaan is, en zich onkwetsbaar voelt, maar zeker in het licht van de latere gebeurtenissen is dat juist het punt: Mandaat wil niets liever dan 'aangedaan' worden.

De andere herinnering speelt zich af bij een bruiloft in een studentenvereniging. Mandaat volgt een vrouw naar boven die hem al 'pssst' zeggend meelokt. In eerste instantie laat het hem nog tamelijk onverschillig: 'hij wou wel eens zien of wat hij dacht dat er zou gebeuren ook precies zo gebeuren zou, meer niet 
[...]' (250). Maar als ze eenmaal - op een wat muf en zanderig bed - liggen te vrijen, krijgt Mandaat er zelfs plezier in: 'haar huid was zo zacht en glad en alert als hij eerlijk gezegd nog nooit een huid gevoeld had' (251). Dan klinkt plotseling applaus en bravo-geroep, en gaat het licht aan. Ze blijken zich op een podium te bevinden waar een groep toeschouwers ('minstens tien zo te horen' (251)) hun verrichtingen staat te bekijken. Mandaat vlucht wederom, 'struikelend over de decorstukken voor De Hertogin van Amalfi, bloeddrama van John Webster' (251). De verwijzing naar dit zeventiende-eeuwse stuk, The Duchess of Malfi, is veelzeggend. Het gaat over het ontmaskeren van een clandestien huwelijk. ${ }^{24}$

Deze twee herinneringen tonen Mandaats pogingen tot seks met een vrouw, maar deze pogingen tot heteroseksueel contact mislukken. Ze zijn gesitueerd in de buitenlucht en op een podium, en zo blijken de intiemste handelingen, waarvoor de slaapkamer, het bed de symbolische plaats is, te worden gezien en beoordeeld door een derde partij. Seks, de keuze voor een seksuele partner, en daarmee seksuele voorkeur, is niet zomaar een persoonlijke kwestie of beslissing in Letter en Geest. Het is een keuze die wordt geobserveerd, en moet worden 'goedgekeurd', of op zijn minst moet worden bevestigd door een derde partij. De verwijzing naar The Duchess of Malfi suggereert dat wat Mandaat met de vrouw aan het doen is, clandestien is. Mandaat moet zijn mandaat verdienen om de daad te verrichten, maar krijgt het niet. Zijn pogingen om iets (seks, liefde lijkt hier niet aan de orde) met een vrouw te delen mislukken.

In een roman die als belangrijkste plotlijn heeft het verhaal van een man die een baan beschouwt als de manier om met anderen te leven, dus via iets wat gewoonlijk wordt geassocieerd met de openbaarheid, lijken deze twee herinneringen over intieme verlangens en seks - privé-kwesties - niet te passen. Flashbacks in romans dienen gewoonlijk als een soort verklaring voor het gedrag van de personages. Hoe zit dat dan in Letter en Geest? Al lijken de twee domeinen

\footnotetext{
${ }^{24}$ The Duchess of Malfi behoort tot de zeventiende-eeuwse traditie van Jacobijns drama, die als voorloper van de gothic novel beschouwd kan worden en waarin afstamming en usurpatie centrale thema's zijn. De hertogin uit de titel, die met een bediende was getrouwd uit liefde, wordt door haar broer met haar onacceptabele daad geconfronteerd via een afgehakte hand. In de cruciale scène, als de dode hand ontdekt wordt, gaat ook het licht aan: Ferdinand, [de broer van de hertogin, AA] 'I come to seal my peace with you: here's a hand.' Gives her a dead man's hand [with a ring]

Hertogin: 'I affectionately kiss it. [...] You are very cold. I fear you are not well after your travel [Bosola brings up lights] Ha! Lights! O horrible!

Ferdinand: 'Let her have lights enough' Exit (geciteerd in Rowe 1999, 98). Voor een uitvoerige analyse van Websters drama en de gotieke machinerie (in de vorm van hekserij en de afgehakte hand, zie Rowe (1999), vooral hoofdstuk 3 en 4.
} 
van werk en seks niets met elkaar te maken te hebben, ik denk dat het hoofdstuk 'Twee beschamende herinneringen' wel een verklarende functie heeft. Mandaat mislukt juist omdat in Letter en Geest de vertogen van het openbare en privé-leven door elkaar lopen, dat van werk en seks. In het verleden speelde zijn werk zich af in de privé-sfeer (in zijn bed), en zijn (pogingen tot) seks in de openbaarheid. In zijn nieuwe baan zou hij die verwarring, die geleid heeft tot mislukkingen en eenzaamheid, achter zich willen laten en zou hij de zaak om willen draaien. Maar werk en seks, de twee gebieden die Mandaat het liefst gescheiden zou houden, raken het meest pregnant vermengd in zijn nieuwe baan, in het contact met zijn collega en superieur, Van Uffel. Dat contact wordt dan ook met de meeste gotieke effecten vormgegeven.

\section{GOTIEKE PERVERSIE}

Van Uffel, wiens volledige naam B.C. Latour van Uffel is, is lid van de directie. Hij is onmiskenbaar de meest gotieke figuur in Letter en Geest. Hij heeft een dubbele naam met een Franse klank (de Eiffeltoren klinkt erin mee), wat hem een aristocratisch karakter geeft en een air van traditie. Van Uffel blijkt tot priester gewijd te zijn, al heeft hij het ambt nooit uitgeoefend (het blijkt toepasselijk dat Mandaat het bestaan van het spook aan hem heeft opgebiecht). Deze elementen doen de lezer van de gothic in Van Uffel onmiddellijk de trekken van de stereotiepe gotieke schurk herkennen - van de verdorven edelman bij Walpole (1765) tot de corrupte monnik van Lewis (1796) of Maturin (1820). Van Uffel is de slechterik tot de derde macht: geperverteerde katholiek en edelman (hij laat immers de helft van die naam achter zodra hij op zijn werk arriveert), en bovendien nog homoseksueel, al herkent Mandaat hem niet als zodanig.

Op de avond dat Van Uffel met Mandaat meegaat naar de Kapel - een locatie waar hij als voormalig priester op zijn plaats lijkt - om het spook te betrappen, gaan ze eerst uit eten. Mandaat ziet dat Van Uffel bij die gelegenheid nog weer een nieuwe identiteit aanneemt, hij is niet de privé-persoon, maar ook niet de publieke persoon. De nieuwe Van Uffel draagt een blazer, 'en uit een openstaand overhemd bloeit een zijden sjaaltje op' (hij draagt dus een choker). Zijn kleine snorretje is niet langer grijzend maar egaal zwart, ziet Mandaat (geverfd? vraagt hij zich af), en Van Uffel houdt zijn pink 'merkwaardig gekromd' (255). Eerder werd al duidelijk dat Van Uffel zijn neiging tot roddelen nauwelijks kan bedwingen. Van Uffel wordt hier met andere woorden neergezet als 
het stereotype van de oudere nicht, maar Mandaat herkent dat stereotype niet. ${ }^{25}$ Even later in de Kapel herkent Mandaat opnieuw niet de homoseksuele verlangens van zijn collega. Hij denkt dat Van Uffel gegrepen is door een metafysisch verlangen ('dat zie je aan de gotische verdraaiing van zijn wenkbrauwen en voorhoofdsvel' (258)), terwijl die op het punt staat Mandaat aan te randen. Van Uffel zegt dat hij zo graag weer iets met zekerheid wil voelen (wat je een empirisch verlangen zou kunnen noemen), en voegt de daad bij het woord: 'hij legt zomaar zijn hand op Mandaats wang [...]' (258). Vervolgens legt hij zijn hand ('het werktuig van de Heer') in Mandaats kruis: 'Mandaat [merkt] aanvankelijk niet $[\ldots]$ dat de warmte die hij door zijn kruis voelt vloeien hem wordt meegedeeld door het andere werktuig van de Heer' (259).

In een lange monoloog vertelt Van Uffel vervolgens aan de vluchtende en zich verschuilende Mandaat over zijn priesterwijding en zijn uittreding, en over zijn regelmatige bezoekjes aan een homobar annex -cinema, waar hij zich gekleed in een jurk laat bevredigen door jonge jongens. ${ }^{26}$ Ook vertelt Van Uffel hoe hij 's nachts parken bezoekt waar mannen seks met elkaar hebben. Hij treedt daar op als scheidsrechter: hij begluurt homostellen en blaast op zijn fluitje, juist voordat ze klaarkomen. Hij doet dat om wat volgens hem een imitatie van echte hartstocht is, te ontmaskeren en de mannen te behoeden voor verder zelfbedrog. Van Uffel treedt dus op als derde partij die seks tussen anderen voortijdig afbreekt. Structureel is dat dezelfde positie als de jongen en de toeschouwers die Mandaat verjoegen. Dat suggereert dat ook Mandaat in zijn pogingen tot heteroseksueel contact werd behoed voor verder zelfbedrog, voor de imitatie van echte hartstocht.

De jonge, onschuldige Mandaat wordt dus belaagd door de oudere gotieke schurk Van Uffel, de man die hij had meegenomen als toegang tot ware kennis, maar die er een heel andere manier van kennen op na blijkt te houden. Wat

\footnotetext{
${ }^{25}$ Linmans merkt dit als enige op: 'Van Uffels homowereld is er nog een van bordelen, hoerenjongens, donkere bosjes en 'boze mannen'. Een wereld van vóór de aids en nog nauwelijks aangeraakt door de zegeningen van de homo-emancipatie van de jaren zestig' (Linmans 2006, 30) en: 'Van Uffel is nog niet uit de kast gekomen (Linmans 2006, 30). Het herhaalde gebruik van 'nog' wijst erop dat Van Uffel een oude(rwetse) homoseksualiteit vertegenwoordigt. Linmans beschouwt Van Uffel 'niet alleen [als] vehikel van Kellendonks worsteling met het geloof, maar ook van zijn homoseksualiteit' (30).

${ }^{26}$ Marjorie Garber stelt dat de combinatie van seksuele en religieuze grensoverschrijdingen juist in de gothic verschijnt in de figuur van een monnik, non of priester in travestie (zie Garber 1992, 218-219), een figuur als Van Uffel dus. Ook Sedgwick wijst op de connecties tussen katholicisme en homoseksualiteit, die ver teruggaan: 'Catholicism [...] is famous for giving countless gay and proto-gay children the shock of the possibility of adults who don't marry, of men in dresses, of passionate theatre' (Sedgwick 1990, 140).
} 
Van Uffel doet met Mandaat is anders dan wat hij in het park doet: niet als scheidsrechter maar als partner probeert hij hem te ontmaskeren - te outen. Van Uffel hint op de mogelijke homoseksualiteit van Mandaat - niet voor niets zegt hij dat hij hem herkende als een solitair, en als een broer: Van Uffel denkt dat Mandaat 'van de familie' is, zoals dat heet. Hij nodigt hem uit om met hem mee te komen naar de homobar. Van Uffel zegt dat hij een woord wil uitspreken waarvan hij weet dat het hem zou kunnen redden, en hij hoopt dat hij het ten overstaan van Mandaat kan zeggen, als die met hem meekomt naar het bordeel. Het onuitspreekbare woord waar een aantal keer op gezinspeeld wordt, is, zo hebben de meeste critici geconcludeerd, het woord 'liefde': 'een woord dat, onbeantwoord, even waardeloos is als een halve wasknijper' (87). Liefde bestaat alleen tussen mensen, het is sociaal, het moet gedeeld worden. Van Uffel en Mandaat kunnen het woord echter niet delen. Waarom niet? Omdat Mandaat domweg niet wil? Omdat Van Uffel alleen op seks uit is terwijl Mandaat op zoek is naar liefde? Of omdat ze beiden iets zoeken wat onuitspreekbaar is, 'a love that doesn't dare to speak its name', zoals Lord Alfred Douglas, geliefde van Oscar Wilde het formuleerde? ${ }^{27}$

Als Van Uffel Mandaat aanrandt, reageert Mandaat door weg te vluchten en vervolgens Van Uffel hardhandig te beroven van de sleutels van de Kapel, deze parodie op een trouwkapel. Mandaat is in paniek: 'Het geweld van de overval staat in geen verhouding tot de weerstand die Mandaat ontmoet' (264). Kennelijk is hij niet in staat om Van Uffels uitnodiging om mee te gaan naar het bordeel simpelweg af te wijzen. Mandaat lijkt bevangen door homosexual panic: de angst om homoseksueel te zijn of om ervoor aangezien te worden; de angst om geperverteerd te worden. Hij voelt zich serieus bedreigd en toont zo dat hij vatbaar is voor de aantijging van homoseksualiteit, al kan of wil hij niet ingaan op die aantijging. Deze scène wijst op een vermenging van 'the amorous with the murderous in a representation of male rape' (Sedgwick 1990, 163).

Dit was zeker niet wat Mandaat in gedachten had toen hij besloot zijn schaamte over zijn eenzaamheid op te lossen door een baan te zoeken en zijn leven met anderen te delen. Zijn openbare, werkende leven wordt door seksuele, privé-verlangens geïnfiltreerd: hij wordt verliefd op zijn assistente en zijn intieme delen worden door zijn baas betast. Van Uffel symboliseert deze perversie bij uitstek, als vertegenwoordiger van het systeem - directielid - en als aanrander van Mandaat. Met terugwerkende kracht krijgt een van zijn eerste op-

\footnotetext{
${ }^{27}$ Sedgwick citeert een heel aantal omschrijvingen van homoseksualiteit als onuitspreekbaar, o.a. nefandam libidinem, 'that sin which should neither be named nor committed', 'the [...] sin among Christians not to be named'. (Sedgwick 1990, 202).
} 
merkingen tegen Mandaat al een dubbele bodem. Van Uffel is op dat moment nog niet bij name genoemd, en spreekt als de stem van het instituut - toepasselijk in de wij-vorm. Op Mandaats eerste werkdag vraagt Van Uffel aan Mandaat: "'Dit is toch uw eerste baan?" Hij [= Van Uffel] lacht verontschuldigend: "Nou ja, baan ..."' (205). Waarom lacht Van Uffel verontschuldigend? Omdat Mandaats werk niet veel voorstelt, of ook om een andere reden? Ik denk dat Van Uffel hier verschillende betekenissen van het woord 'baan' laat doorklinken. Een baan is niet alleen een betaalde betrekking, maar ook het woord voor openbare ontmoetingsplaatsen voor homo's - de parken die Van Uffel later blijkt te bezoeken. Beide verwijzen naar de openbaarheid. Werk en seks zijn zo van meet af aan hopeloos verstrengeld en hopeloos openbaar - zoals opnieuw duidelijk wordt als Van Uffel zijn collega betast, als bevonden ze zich op de baan.

$\mathrm{Er}$ is nog een scène met een veelzeggende verwarring tussen privé en openbaar, tussen seks en werk. Terwijl Mandaat op de wc van een hardnekkige erectie af probeert te komen ('nu zit hij er moederziel alleen voor, anders dan op zijn dertiende, toen hij tenminste Woutje Jansen nog naast zich had, voor wie de ene dienst de andere waard was' (243)), vangt hij een gesprek op tussen twee collega's over de aanstaande lente en de onrust die dan de kop opsteekt. De een zegt: "'Oude bokken, groene blaadjes. De dans der hormonen. [...] Je zou haast gaan uitkijken naar een andere, een andere -". "Vrouw?", vraagt de ander. "Baan, bedoelde ik eigenlijk", antwoordt de eerste man (244).

De urgentie en tegelijkertijd de misplaatstheid van Mandaats verlangen om zijn leven met anderen te delen op zijn werk wordt nogmaals duidelijk als hij na zijn afscheidsborrel met conservator Molhuysen naar het station wandelt. Mandaat probeert Molhuysen de uitspraak te ontlokken dat hij liefde voelt voor zijn werk ('Als u dat woord eens zou uitspreken dr. Molhuysen? U bent zo gewetensvol en precies. Als u het zou uitspreken, dan zou hij geloven dat het iets betekent.' (283). Maar Molhuysen zegt niet meer dan dat hij anderen een dienst bewijst met zijn werk. Mandaats teleurstelling over dit antwoord is maar al te duidelijk. Als Molhuysen hoort dat Mandaat bijna dertig is maant hij hem tot actie: 'Als je ooit iets wilt doen, weet je, dan is het hoog tijd om ermee te beginnen' (283, cursief in origineel), waarop Mandaat uitroept: 'O, ik voel voortdurend een hete adem in mijn nek. Ik ben wild van paniek!' (283). De daad die Mandaat hoognodig moet verrichten om volwassen te worden vervult hem met paniek. Liefde kan niet in het werk gevonden worden, en ondertussen wordt het werk geperverteerd door seks. Het is niet voor niets dat Mandaat zijn spook op het werk tegenkomt. Via de zoektocht met Van Uffel naar het spook, komt 
hij het spook van de homoseksualiteit tegen, dat zowel op de baan als in zijn baan rondwaart.

Mandaats angst is vele malen groter ten overstaan van een 'echte', belichaamde homoseksueel, Van Uffel, die geschetst wordt in alle mogelijke karikaturen, dan ten overstaan van het spook. Het spook leidt naar een verschijning van homoseksualiteit: zowel aan- als afwezig, ongrijpbaar en onkenbaar, de schaduw van alle vrijgezellen in deze roman. Kralt, Vervaeck, Oppelaar en Goedegebuure hebben in feite allemaal gelijk. Het spook is de geest van Brugman, maar ook een spiegelbeeld van Mandaat. Dat spook verdwijnt als zich een ander potentieel spiegelbeeld van Mandaat aandient, een mogelijke partner: Van Uffel, de man die in het bordeel naar zichzelf in de spiegel 'liefde' roept. Het is volkomen begrijpelijk dat het spook zich niet laat zien. Van Uffel is geen geschikte modest witness: hij is niet onbetrokken, niet transparant, ja spookachtig genoeg. Van Uffel had Mandaat beloofd om formules te zoeken om het spook uit te drijven - als priester zegt hij dat te kunnen - maar het is duidelijk dat dat geen formules van de moderne wetenschap zijn, maar metafysische. Uitdrijven blijkt niet nodig: Van Uffels eigen aanwezigheid is voldoende. Een homoseksueel in levenden lijve, en dan nog wel zo'n oude nicht, blijkt voor Mandaat nog veel angstaanjagender dan het spook, want 'it takes one to know one' zoals Sedgwick zegt ${ }^{28}$, een uitdrukking die misschien nog het beste te vertalen is met 'ons kent ons', of 'hij is van de familie'.

Van Uffel kan hem kennen. Dat is een manier van kennis vergaren waarvoor je 'zo' moet zijn om te kunnen kennen. Dat is dus geen wetenschappelijke epistemologie die gebaseerd is op objectiviteit, maar de epistemology of the closet (de titel van Sedgwicks boek), de epistemologie van de kast. Die manier van kennis vergaren gedijt juist niet bij onbetrokken, objectieve waarneming, integendeel. Lukte het Mandaat nog om via het ontwerpen van een particuliere epistemologie het spook onder controle te houden, bij Van Uffel slaagt hij daar niet in.

\section{ONS KENT ONS}

Mandaats pogingen tot heteroseks mislukken; en de toenaderingspogingen van een homoseksueel wijst hij af. Wat betekent dat? Een ongetrouwde man van dertig roept vragen op in een heteroseksuele maatschappelijke orde: waarom heeft hij nog geen vriendin? Is hij niet goed, of... is hij homo? Het eerste is met

\footnotetext{
${ }^{28}$ Zie Sedgwick (1990), p. 100, 152, 156, 169, 222, 225.
} 
klem door Mandaat ontkend ('tenzij hij gek is, maar ach nee, dat is hij niet' (233)). Voor een derde optie (geen partner hebben, oftewel single zijn, is ook normaal) lijkt geen plaats. Zit Mandaat soms in de kast? Er zijn allerlei 'tekenen' die als 'bewijs' van zijn homoseksualiteit gelezen kunnen worden. ${ }^{29} \mathrm{Om}$ te beginnen is daar Van Uffel, die hem met zijn 'epistemologie van de kast' herkent als een 'broer'. Dan zijn er nog de terloopse opmerkingen over de diensten van Woutje Jansen, Mandaats eerdere verblijf in leger en kostschool, en zijn vrijgezelle staat, waar hij zich voor schaamt. En dan zijn mislukkingen als hetero. Niet alleen in het verleden ging het mis, ook tijdens zijn periode in de bibliotheek is Mandaats verliefdheid gedoemd te mislukken. Zoals Van Uffel driedubbel gotieke schurk is, zo is mevrouw Qualing driedubbel onwaarschijnlijk als object van verlangen: ze is onaantrekkelijk (haar jurk is nu eens grijs, dan weer grauw), ze heeft harige kuiten, draagt 'verstandige schoenen' en een dikke bril en is bovendien zwanger van een ander. Na zijn afscheidsborrel ziet hij voor zijn geestesoog nog 'een Indisch meisje uit Voorburg' verschijnen, maar het gevoel dat hij voor haar opvat is weliswaar 'prachtig', maar 'meteen al hopeloos' (285).

De 'tekenen' zijn echter niet eenduidig of helemaal overtuigend. Nergens in de roman staat expliciet dat Mandaat homoseksueel is. Sedgwick noemt de neiging om een onuitgesproken seksuele voorkeur te lezen als homoseksualiteit 'We Know What That Means' (Sedgwick 1990, 204). De afwezigheid van seksualiteit wordt maar al te vaak geïnterpreteerd als homoseksualiteit - iets wat Sedgwick ook terugziet in de vrijgezellenliteratuur die ze bespreekt. Wie ertoe neigt om Mandaat te outen identificeert zich met het perspectief van Van Uffel: de homoseksueel die als scheidsrechter optreedt voor andere homoseksuelen. Dat is begrijpelijk, omdat de focalisatie in Letter en Geest soms duidelijk bij Van Uffel ligt, maar het verraderlijke is dat die soms ongemerkt overgaat naar Mandaat - waarmee de paranoia waarover Sedgwick spreekt (wie weet wat van wie?) doeltreffend wordt vormgegeven. Het effect is dat Van Uffel als gothic double van Mandaat diens gedachten lijkt te kunnen lezen.

Van Uffel is echter geen betrouwbare modest witness: hij hanteert de 'epistemologie van de kast', van ons-kent-ons. We kunnen Mandaats gedachten niet lezen en we kunnen niet in zijn 'kast' kijken. We kunnen niet eens zeker weten of er wel een kast is, we hebben alleen Van Uffels gaydar. Hooguit kunnen we vaststellen dat de vrijgezel Mandaat wordt bevangen door (male homosexual) paniek, en dat hij faalt als heteroseksueel. De roman manipuleert het verlangen van de lezer om te weten, om conclusies te trekken over Mandaats privé-leven,

\footnotetext{
${ }^{29}$ En ook zo gelezen zijn: zie noot 15 .
} 
terwijl Mandaat niets liever wil dan aanvangen met zijn openbare leven, en naar een wereld verlangt waarin privé-voorkeuren en openbaarheid juist strikt gescheiden zijn. Die wereld bestaat niet (meer), zo blijkt in de bibliotheek. Die vervaging van grenzen tussen privé en openbaar past bij de tijd waarin Letter en Geest verschijnt, begin jaren tachtig. In het voorgaande decennium waren ideeen over de grenzen tussen privé en openbaar juist op het punt van seksuele identiteit ingrijpend veranderd.

Letter en Geest verschijnt in 1982, op een moment dat de homoemancipatie in Nederland zeer succesvol is. ${ }^{30}$ De kast waar Sedgwick het over heeft kan open: homoseksuelen zijn waarschijnlijk niet eerder zo zichtbaar, maatschappelijk geaccepteerd en gelijkberechtigd geweest dan op dat moment in Nederland. Mandaats mislukking als heteroseksueel lijkt synoniem met zijn maatschappelijke mislukking. Maar waarom eigenlijk? Als hij homoseksueel is, kan hij daar toch gewoon voor uitkomen? Waarom wordt de verschijning van homoseksualiteit in Letter en Geest zo gotiek vormgegeven? Dat heeft volgens mij te maken met een nieuwe notie van homoseksuele identiteit die juist door de homo-emancipatie van eind jaren zestig ontstaat.

De sociologen Chabot en Duyvendak (2002) beschrijven hoe coming-out, een term die in 1969 door het Amerikaanse Gay Liberation Front werd geïntroduceerd, een nieuwe strategie van homo-activisme inluidde, waarbij 'public declarations of homosexuality became a form of collective action and an expression of commitment (Chabot \& Duyvendak 2002, 713). Voordien was homoseksualiteit meestal een geheim, dat hooguit met andere homoseksuelen werd gedeeld. Door coming out veranderde homoseksuele identiteit van een gedeeld geheim in een gedeelde openbare identiteit. Jeffrey Weeks onderscheidt drie aspecten van coming out:

First of all it involved coming out to yourself [...]; secondly, it involved coming out to other homosexuals [...]; but thirdly, and most crucially, it meant coming out to other people, declaring, even asserting your sexual identity. (Weeks in Chabot \& Duyvendak 2002, 713)

\footnotetext{
${ }^{30}$ Zie Duyvendak (1994), met name 32-38, 40-59, Kennedy (1995, p. 141 e.v.), Tielman (1982) Hekma (2004). Stonewall 1969 wordt vaak als het begin van de homo-emancipatie in de Verenigde Staten beschouwd. In Nederland was het proefschrift van Sengers (1969) belangrijk voor die emancipatie. In 1971 werd artikel 248bis afgeschaft (het artikel dat homoseksueel contact tot 21 jaar strafbaar stelde). De AIDS-epidemie die halverwege de jaren tachtig uitbrak (dus nadat Letter en Geest verscheen) maakte een voorlopig einde aan de korte periode van groeiende homoacceptatie.
} 
Weeks verbindt de strategie van coming out expliciet met de mogelijkheid om een gemeenschap te vormen: 'it promised a new community, a real community where one could $b e$, as opposed to the traditional sub-culture where one had to pretend (Weeks in Chabot \& Duyvendak 2002, 713) [cursief in origineel]. Met andere woorden: het spel van schijn en wezen hoeft door coming out niet langer gespeeld te worden door moderne, geëmancipeerde homoseksuelen. Ze kunnen zichzelf zijn door te zeggen wie ze zijn. Ze worden geen deel van de gemeenschap door een geheim te delen, maar juist door open te zijn, door uit de kast te komen. In het openbaar de keuze voor een geliefde van hetzelfde geslacht uitspreken is het toegangskaartje tot de gemeenschap. De emancipatorische waarde van deze nieuwe coming out-strategie kan niet onderschat worden. Er is echter ook een keerzijde: wie zich niet uitspreekt, of wie zich in de ogen van de gemeenschap op een verkeerde manier uitspreekt, kan geen lid worden. De mogelijkheid om een seksuele identiteit te claimen - hoe noodzakelijk en bevrijdend die ook was en is voor talloze homoseksuele mannen en vrouwen -, gaat gepaard met iets dat op noodzaak of zelfs dwang gaat lijken: als je geen seksuele identiteit claimt besta je niet; en dat geldt vooral voor de homoseksueel. Seksuele voorkeur is in het nieuwe coming out-vertoog niet alleen een persoonlijke zaak, maar ook een publieke. Letter en Geest laat zich lezen als een commentaar op die ontwikkeling.

Ook Stephan Sanders (1995) leest bij Kellendonk een kritiek op de nieuwe homo-identiteit, overigens zonder verwijzing naar Letter en Geest. Volgens Sanders heeft de snelle homo-emancipatie, in Nederland ingeluid door de 'zelfaanvaardingshypothese' van de psychiater Sengers (Homoseksualiteit als klacht, 1969), geleid tot een 'gepantserde, politieke homoseksualiteit, een seksuele voorkeur voor op de barricaden [...]' (Sanders 1995, 138). Sengers stelde dat zelfaanvaarding bestond bij de gratie van de mededeelbaarheid van het zelf, en Sanders ziet hoe die mededeelbaarheid van de moderne homoseksueel is uitgemond in wat hij noemt zelfverheerlijking, een vorm van chauvinisme waarbij men samenvalt met zijn identiteit. ${ }^{31}$ Dat chauvinisme ontbreekt bij Kellendonk ten enenmale, aldus Sanders. ${ }^{32}$ Hij ziet in Kellendonks werk 'oude spoken' een treffende beeldspraak in verband met het gotieke in Letter en Geest. Sanders schrijft: 'Er klinkt iets ouds mee in wat Kellendonk over homoseksualiteit te

\footnotetext{
${ }^{31}$ Zie ook Duyvendak (2006).

32 Sanders leest Kellendonks uitlatingen over homoseksualiteit niet zozeer als een aanval op of een afwijzing van een tolerant, homovriendelijk klimaat - Kellendonk is niet voor niets zelf een product van dat klimaat - maar als een zeldzaam ongecensureerde manier van spreken. Zie ook Dullaart (1993), die ook ingaat op de politisering van seksualiteit, onder andere naar aanleiding van Mystiek lichaam.
} 
zeggen heeft. De band met de antieke tijd, dus die van vóór ' 69 , is bij hem niet doorgesneden. Wie dat verouderd wil noemen, doet daarmee hooguit een uitspraak over zijn eigen tijdsperspectief.' (Sanders 1995, 136). ${ }^{33}$ Sanders ziet met andere woorden een oude homoseksuele identiteit verbeeld in Kellendonks werk. In Letter en Geest manifesteert die oude identiteit zich in de figuur van Van Uffel. Een verbeelding van de nieuwe homo-identiteit ontbreekt.

Een gangbaar idee over Nederlandse literatuur is dat daar de seksuele revolutie plaatsvond - auteurs als Jan Wolkers, Gerard Reve, en W.F. Hermans durfden te schrijven wat het grote publiek nog niet eens durfde te denken. Evenzo geldt dat de homo-emancipatie de bestaansvrijheid van homoseksuelen onmiskenbaar verruimd heeft. Maar die emancipatie heeft een keerzijde. Als zijn (bestaan als homoseksueel) afhangt van kennen (jezelf (er)kennen, jezelf kenbaar maken aan anderen en door anderen erkend worden), dan is homoidentiteit iets dat in het openbaar geclaimd en opgevoerd (performed) moet worden. Kellendonk laat in Letter en Geest via het gotieke treffend zien welke paniek er kan ontstaan als je je moet bewijzen als seksueel subject. Hij herschrijft het klassieke spookverhaal om de ambivalenties te verbeelden die, in dit geval, het claimen van een seksuele identiteit met zich meebrengt. Terwijl het klassieke spookverhaal zijn spanning ontleent aan het 'probleem van het zijn' (bestaat het spook of niet?), zet Mandaat in Letter en Geest dat probleem onmiddellijk naar zijn hand door zijn ontmoeting met een spook in de bibliotheek als 'een probleem van de kennis' te benaderen. Maar zelf wil of kan hij zich niet laten kennen. Hij past niet bij de oude homoseksuele identiteit (Van Uffel), maar ook niet bij de nieuwe (coming out). Ten overstaan van de dreigende perversie (Van Uffel) kiest Mandaat niet. En als hij zich wel laat kennen, zoals in 'Twee beschamende herinneringen', dan schrikt hij van de publieke reacties. Interessant genoeg is bij Kellendonk ook heteroseksualiteit een publieke performance, een daad die in het openbaar opgevoerd moet worden. Mandaats coming $o u t$ als hetero mislukt echter jammerlijk. Wie zijn seksuele identiteit niet in het openbaar wil claimen, welke dan ook, bestaat in feite niet. Zoals de zwerver die Mandaat op zijn laatste treinreis tegenkomt scherp observeert: 'Dat zwijgen kan je lelijk opbreken jongeman. Wie zwijgt heeft niet bestaan.' (286).

Mandaat kan niet voor- of achteruit en eindigt letterlijk 'onbeweeglijk als een punt' (287) op het perron, voor eeuwig gevangen in het moment. Volgens Richard Dyer zijn er vier mogelijke verhaaleindes voor het stereotype van de homoseksuele 'sad young man' beschikbaar: 'death, normality, becoming a

\footnotetext{
${ }^{33}$ Ook Postma (2003) belicht de keerzijde van de openheid over seksualiteit, en geeft daarbij als voorbeeld de nadruk op coming out in de voorlichting aan homoseksuele jongens.
} 
dreadful old queen or, especially in the later texts, finding "someone like oneself" with whom one can settle down' (Dyer 1993, 88). ${ }^{34}$ Deze vier opties lijken in het geval van Mandaat zo nadrukkelijk niet te worden gekozen (hij gaat niet dood maar blijft onbeweeglijk staan, de keuze voor heteroseksualiteit is afgewezen, een oude nicht als Van Uffel wil hij niet worden en zijn leven delen lukt niet), dat hij inderdaad dat stereotype op geen enkele manier kan belichamen.

Zodra Mandaat ontslag genomen heeft komt de geschiedenis tot stilstand: al zijn treinreizen worden een reis, al zijn werkdagen dikken in tot één herinnering. Terwijl hij gefixeerd wordt, worden zijn collega's getransfigureerd: in zijn herinnering krijgt de gemeenschap van zijn collega's een religieuze gloed - allemaal met een glimlach op hun gezicht die hun band bevestigt: 'Hij ziet ze als het ware in een kring zitten. Ze houden elkaar hun gezichten toegewend en Mandaat begrijpt dat ze iets met elkaar hebben, iets waar hij nooit bij zal kunnen [...]' (284). Zij vormen een 'Gemeenschap van Heiligen', een 'Mystiek Lichaam'.

Ik denk dat we hier getuige zijn van de geboorte van nostalgie: de creatie van een geïdealiseerd beeld van het verleden. Peter Fritzsche (2001) heeft de ervaring van een breuk tussen heden en verleden, en het daarmee gepaard gaande ontstaan van historisch besef, aangewezen als het moment waarop nostalgie ontstaat. ${ }^{35}$ In Letter en Geest wordt het ontstaan van een breuk tussen heden en verleden zelf gethematiseerd. Terwijl nostalgie gaat over een verlangen naar een verleden dat definitief voorbij is, is die breuk in de gotieke roman zelden definitief. Er zijn grensoverschrijdingen, vervagende grenzen, of ambivalenties die het verleden doen terugkeren in het heden of andersom. Isabella van Elferen, samensteller van een bundel over het gotieke met de titel Nostalgia or Perversion? stelt dat het gotieke vaak in termen van nostalgie, of in termen van perversie beschreven wordt: 'Gothic literature, film, and subcultures, are often qualified as either nostalgic or perverse, or as both (Van Elferen 2007, 4). In Letter en Geest blijkt de vraag hoe nostalgie en perversie zich tot elkaar verhouden cruciaal. Het tamelijk ongebruikelijke begrippenpaar nostalgie en perversie kan al-

\footnotetext{
${ }^{34}$ Met dank aan Roel van den Oever.

${ }^{35}$ Nostalgie, aldus Fritzsche 'is a fundamentally modern phenomenon because it depended on the notion of historical process as the continual production of the new' (Fritzsche 2001, 1589). Fritzsche laat de verwantschap tussen modern historisch besef, nostalgie en het gotieke met zoveel woorden zien: 'Strange places at the beginning of the nineteenth century, such as Frenchman's Island, and also attics, haunted houses, and the remote villages the Grimms believed they had stumbled upon, indicate the extent to which everyday material life bore the marks of newly imagined ruptures of history (Fritzsche 2001, 1616, mijn cursivering). Over het ontstaan van nostalgie door historisch besef: zie ook Lowenthal (1985), 4-13.
} 
leen een betekenisvol contrast vormen als de termen een bepaalde grond delen in logische termen: als ze deel uitmaken van dezelfde verzameling. ${ }^{36}$ Als we veronderstellen dat het tegenovergestelde van nostalgie perversie is, doen zich twee mogelijke gemeenschappelijke delers voor: een morele en een seksuele.

Om met de eerste, morele dimensie te beginnen: pervers is wat afwijkt van wat normaal is, en wat als moreel als 'slecht' wordt beschouwd. Als nostalgie wordt geponeerd als contrast van perversie, verkrijgt dat begrip ook een morele lading, en wel een deugdzame. Zo wordt nostalgie de 'onschuldige' van deze twee begrippen, dankzij de tegenoverstelling. De tweede gemeenschappelijke deler is de seksuele lading. Het begrip perversie wordt met name in seksuele contexten gebruikt, en betekent dan de afwijking van de heteroseksuele norm, of dat nu homoseksualiteit, bestialiteit of sadomasochisme is. Gewoonlijk heeft nostalgie geen seksuele lading - maar als betekenisvol contrast van perversie wordt het woord nostalgie met een seksuele betekenis geladen. Als 'tegenovergestelde' van seksuele perversie kan nostalgie twee invullingen krijgen. Ten eerste kan het tegenovergestelde van perversie 'normale' (hetero)seksualiteit zijn, ten tweede kan het de afwezigheid van seksualiteit impliceren. Nostalgie verwijst dus ofwel naar de staat van normaliteit, de norm van heteroseksualiteit, of naar het niet-seksuele. Die staat van niet-seksueel zijn kan weer als verwijzing naar die morele betekenis van nostalgie worden opgevat: nostalgie als onschuld.

Om de dreiging van perversie te ontlopen, is de enige uitweg voor Mandaat, zo lijkt het einde van Letter en Geest te impliceren, een keuze voor nostalgie, de keuze om weer uit de geschiedenis te stappen (die mythe van de moderne tijd, de geschiedenis als vooruitgang). Als (hetero)seksuele normaliteit onbereikbaar blijkt voor Mandaat, kiest hij de andere mogelijke oppositie van perversie die ik zojuist noemde: de afwezigheid van seksualiteit, zelfs als dat betekent dat hij daardoor uit de geschiedenis stapt. Mandaat kiest dus nostalgie in plaats van perversie, of sterker nog: Mandaat transformeert het geperverteerde heden in een nostalgisch verleden, maar dat is een keuze tegen een hoge prijs: de prijs van de stilstand, van nooit meer bewegen. Volgens literatuurwetenschapper Linda Hutcheon komt de emotionele impact van nostalgie voort uit de ontoegankelijkheid van het verleden (Hutcheon 2000). Nostalgie is de reactie op het treurige feit dat tijd onomkeerbaar is, dat het verleden voorgoed onbereikbaar is. Ik zou willen stellen dat Letter en Geest dat besef tot zijn radicale consequentie doorvoert. De consequentie van Mandaats onvermogen om in het heden een

\footnotetext{
${ }^{36}$ Een voorbeeld om dit te verhelderen: rood is het tegenovergestelde van zwart als de gemeenschappelijke deler een roulettebord is. Als de gemene deler een stoplicht is, kan groen gelden als het tegenovergestelde van rood.
} 
gemeenschap te realiseren - wat voor vorm van gemeenschap dan ook, pun intended -, om deel te zijn van de geschiedenis, is om eruit te stappen. Mandaats tijd verstrijkt niet langer. 



\section{3}

\section{BEZITTEN EN BEZETEN WORDEN De vierde man van Gerard Reve'}

Begin 1980 deed Gerard Reve (1923-2006) de toezegging om het boekenweekgeschenk voor 1981 te schrijven. ${ }^{2}$ Daar was de opdrachtgever, de Stichting Collectieve Propaganda van het Nederlandse Boek (CPNB), verguld mee. Het jaarlijkse boekenweekgeschenk was meer en meer een cadeauboekje geworden dat met literatuur weinig te maken had, en die trend wilde men graag keren. $\mathrm{Nu}$ was het gelukt om een grote naam te strikken, al was Gerard Reve geen onomstreden auteur. Zijn homoseksualiteit, zijn bekering tot het katholicisme en de manier waarop hij deze twee elementen vanaf de jaren zestig met elkaar verbond, zoals in de befaamde Ezelscène uit Nader tot $U$ (1966), zouden lezers nog altijd kunnen schokken. De CPNB wilde graag alle boekhandelaars en lezers te vriend houden. Het geschenk mocht daarom geen ophef veroorzaken. Christelijke boekhandelaren hadden in voorgaande jaren al aan het monopolie van de stichting gemorreld door met een alternatief boekenweekgeschenk te komen. De CPNB liet Reve daarom zwart op wit beloven dat hij niet over de herenliefde zou schrijven. Zo werd De vierde man een van de weinige boeken in Reves oeuvre met een overwegend heteroseksueel thema. ${ }^{3}$ Reve kon het echter niet laten om enige homoseks in het verhaal te verwerken, en bovendien werden sommige heteroseksuele passages door de Boekenweekwerkgroep godslasterlijk

\footnotetext{
${ }^{1}$ Een sterk bekorte versie van dit hoofdstuk verscheen als Andeweg (2007b).

${ }^{2}$ Bron voor deze alinea: Mulder (1981) en televisieprogramma Andere Tijden (VPRO, 8 maart 2001).

${ }^{3}$ Niet het enige: In Oud en eenzaam (1978) heeft de hoofdpersoon (Gerard) een verhouding met een zekere Jane Raleigh. Hij gaat zowel met haar als met haar (homoseksuele) huisgenoot Jacky, beiden acteurs, naar bed.
} 
gevonden. ${ }^{4}$ Het gevolg: de CPNB wees Reves inzending alsnog af, contracteerde Henri Knap die (het alom afgekraakte) De ronde van ' 43 schreef, en De vierde man verscheen voorjaar 1981 als 'gewone' roman bij Elsevier/Manteau.

Hoewel diverse recensenten - op de hoogte van de boekenweekepisode De vierde man het karakter van een typisch tussendoortje vonden hebben (zoals Alfred Kossmann, Karel Osstyn en Wim Sanders), waren de meeste wel te spreken over het boek. ${ }^{5}$ Dit was nu eens een Reve zonder 'geleuter' (Ivan Sitniakowsky) - een karakterisering die zijn werk vanaf de Taal der Liefde (1972) steeds meer was gaan aankleven. Reve had sinds de jaren zestig het patent op brievenboeken en romans in de vorm van een reeks bedverhalen - Sexualmärchen noemde Reve die zelf - , meestal zonder echte plot. Dat stramien kende men nu wel, om niet te zeggen dat de waardering ervoor nogal was afgenomen: 'sinds een jaar of twaalf schrijft Reve boeken met meestal wel een paar schitterende en altijd een heleboel stierlijk vervelende bladzijden', aldus Sitniakowsky (1981). Ook Reves nadrukkelijk als autobiografisch gepresenteerde romans Oud en eenzaam (1978) en Moeder en Zoon (1980) waren gemengd ontvangen. De vierde man was voor de verandering een strak gecomponeerd verhaal, dat spannend was bovendien.

Veel recensenten maakten bij verschijnen dan ook opmerkingen over het genre van De vierde man, dat ze als atypisch voor Reve beschouwden. Men las de novelle in termen van lectuur - als populaire literatuur, en niet als 'hoge' literatuur -, en dat terwijl Reve op dat moment gold als een van de 'grote drie' schrijvers, naast Mulisch en Hermans. ${ }^{6}$ Zowel Reves stijl als de verhaalelementen droegen bij aan de perceptie van De vierde man als lectuur.

\footnotetext{
${ }^{4}$ Andere Tijden citeert uit een brief van de CPNB dat de tekst 'controversiële passages' bevatte. Pieter Steinz (2006) veronderstelt dat de heteroseksuele scène godslasterlijk werd gevonden, wat een brief van Reve zelf lijkt te bevestigen. Reve schrijft in een brief aan toenmalig minister Brinkman van Cultuur (d.d. 19 maart 1988) dat een deel van de commissie zich stoorde aan voor katholieken kwetsende passages: 'Wat H. [Hazeu, Reves uitgever, AA] mij erover vertelde kan waar zijn, of alleen maar anecdote. In die Commissie, zo heette het, zaten een aantal godlozen en enkele protestanten, maar geen enkele katholiek. De protestanten dachten, dat de passage op blz. 113 regels $1 \mathrm{t} / \mathrm{m} 7$ kwetsend zoude kunnen zijn voor rooms-katholieken. Katholieken gaan echter nogal huiselijk en boers om met hun symbolen en lezen trouwens zelden boeken, dus ik heb nooit van die zijde enige klacht gehoord' (Reve 1988).

${ }^{5}$ Geraadpleegde recensies: Kossmann (1981), Kuipers (1981), Mulder (1981), Osstyn (1981), Sanders(1981), Sitniakowsky (1981), Smit (1981), Verschoore (1981), Verstappen (1981), Vooren (1981).

${ }^{6}$ Deze Grote Drie wisselen nogal eens van samenstelling in de loop der tijd, wat een onderzoek op zich waard is. Soms zijn het de Grote Vier (Mulisch, Hermans, Blaman, Reve; ook wel Mulisch, Hermans, Wolkers, Reve). Ook al gesignaleerd: de Grote Zes (Steinz 2006). Vestdijk, Claus en Haasse worden ook genoemd als mogelijke kandidaat. Zie ook Heumakers en Kuipers (1991).
} 
Zo noemde Kossmann het 'een verhaal van niets, met de tong in de wang geschreven, parodie op wat men vroeger keukenmeidenromans noemde. Ook in de stijl heel wat parodie. Zo de vele, geheimzinnigheid suggererende puntjes...' (Kossmann 1981). Rob Vooren schreef dat De vierde man zich 'laat [...] lezen als een combinatie tussen een romannetje, een detective en magisch realisme à la Hubert Lampo'. Hij vond het 'een volkomen geslaagd literair romannetjemet-ontsnapping-op-het-nippertje-toe', oftewel 'het beste deeltje van de Bouquet-reeks, een heerlijke ruiker tussen tuiltjes kunstblommen' (Vooren 1981). Reinjan Mulder zag in De vierde man 'een parodie op het soort boeken dat de CPNB tijdens de boekenweek gratis verspreidt' (Mulder 1981). Sitniakowsky, ten slotte, herkende in De vierde man een originele Nederlandse gothic novel:

Vermoedelijk bestaat er in de hele Nederlandse literatuur geen verhaal met zoveel dubbele bodems en 'speciale effecten', [...] geen griezelverhaal waarin de klassieke horror van krakende treden in het donker en geheimzinnige sleutels die in nog veel geheimzinniger deursloten worden gestoken, zo knap wordt aangedaan! (Sitniakowsky 1981)

Er is inderdaad geen ander boek van Reve dat zozeer het karakter van een gothic novel heeft, hoewel er wel meer typisch gotieke motieven in zijn werk zijn aan te wijzen. ${ }^{7}$ In De vierde man betreft het niet een enkel voorval of een enkele scène, maar zijn setting, plot en personages gotiek te noemen. Er heerst een sfeer van naderend gevaar, veroorzaakt door onheilspellende dromen, klapperende deuren, fantoomverschijningen en een kistje dat met een doodkist geassocieerd wordt. De negentiende-eeuwse villa van femme fatale Christine - die terloops wordt vergeleken met een vampier - is de gothic mansion en belangrijkste plaats van handeling. De hoofdpersoon en ik-verteller Gerard ${ }^{8}$ heeft een kortstondige verhouding met deze Christine, als hij na een voorleesavond - hij is schrijver -

\footnotetext{
${ }^{7}$ In De Avonden (1947) heeft Frits van Egters bijvoorbeeld een droom over een doodkist die het huis wordt binnengedragen; hij is bang dat het lijk al aan het rotten is. In Een circusjongen (1975) wordt een onherkenbaar verminkt meisje tegelijk met de ik-verteller geridderd. Zij blijkt hetzelfde meisje dat jaren eerder gruwelijk door hem verkracht is: een typisch gotieke combinatie van gruwelijkheid en onvoorstelbaar toeval. De monniksorde die in Moeder en zoon (1980) Reves oude lagere school heeft betrokken en daar in erbarmelijke omstandigheden leeft, lijkt zo uit een gotieke roman weggelopen. In Lieve jongens (1973) worden Corinne en Woelrat vampiers genoemd (p. 101, p. 41).

${ }^{8}$ Zoals in veel van Reves werk draagt de ik-verteller van De vierde man de naam van de schrijver. Waar ik in het vervolg 'Gerard' schrijf bedoel ik de hoofdpersoon en verteller in De vierde man; waar ik Reve schrijf bedoel ik de auteur.
} 
in de Zuid-Nederlandse stad V. bij haar blijft slapen. Als Gerard echter een foto ziet van Christines vriend Herman vat hij een hevig verlangen op naar deze man, die hij via Christine hoopt te ontmoeten. Als hij een weekend op haar huis past opent hij een kistje dat hem aan een doodkist doet denken, met een sleutel die hij herkent uit een eerdere droom. Het bevat documenten, en zo ontdekt hij dat Christine weduwe is van drie mannen. Dat jaagt hem de angst om het hart, want in een andere droom heeft hij een oude man horen zingen: 'Tierelierelier, wie wordt nummer vier'. Wie zal de vierde man worden, Herman of hij? Uiteindelijk ontvlucht Gerard Christines huis halsoverkop, zonder haar of Hermans komst nog af te wachten. Later hoort hij dat Herman ernstig verminkt is bij een ongeluk in Christines auto.

Ook regisseur Paul Verhoeven herkende de gotieke elementen in De vierde man. Hij maakte in 1983 een succesvolle verfilming van de roman, met Jeroen Krabbé in de rol van Gerard, Renée Soutendijk als Christine en Thom Hoffmann als Herman. Verhoeven volgde het boek niet heel getrouw. Hij zette de griezeleffecten extra dik aan, voegde personages toe (een Mariafiguur) en liet personages weg (Laurens, een jongen die Gerard in de roman oppikt bij de bioscoop en met wie hij in Christines huis naar bed gaat). ${ }^{9}$ Een wezenlijk verschil tussen boek en film is dat in het boek geen ontmoeting plaatsvindt tussen Gerard en Herman, de aanbeden vriend van Christine, en in de film wel. In de roman blijft het bij fantasieën, maar in de film wordt Gerards droom over Herman - waarin hij hem in een kapel aan het kruis ziet hangen - gevolgd door een ontmoeting in Christines huis. De meest gotieke scène van de film is wel die waarin Herman en Gerard seks hebben in een graftombe op het kerkhof, waar ook de urnen van Christines vorige echtgenoten blijken te staan.

Terwijl het gotieke karakter van De vierde man - boek en film - evident is, werkt de opeenstapeling van gotieke decorstukken en clichés vooral in de roman op de lachspieren. Ironie en parodie spelen daarin een grote rol, zoals ook blijkt uit de aangehaalde recensies. De roman kan dan ook het beste als comic gothic gekenschetst worden. In de film zijn de komische aspecten zo goed als verloren gegaan. De ironische bijgedachten van Gerard, zijn zelfrelativering en zijn overdrijvingen komen op het witte doek niet over. Klaus Beekman beschreef in een uitgebreide vergelijking van boek en film hoe de religieuze symboliek en de griezelcomponent in de film veel meer zijn uitgewerkt (Beekman 1986). Volgens Beekman bracht Verhoeven op die manier meer eenheid aan in de film,

\footnotetext{
${ }^{9}$ In de eerder geciteerde brief aan Brinkman uit Reve zijn enthousiasme over die aanpassing van Verhoeven: 'Maar Zij, Maria, vond het kennelijk een mooi boek, want Zij speelt, zonder dat ik daar iets aan heb gedaan, mede in de gelijknamige film!' (Reve 1988).
} 
bijvoorbeeld door herhaling van motieven als het cijfer vier, en de kleuren blauw en rood. Beekman stelt vast dat critici discussiëren over het precieze genre van De vierde man, zowel over het boek als over de film. Het verschil is volgens hem dat 'terwijl men het boek doorgaans beschouwt als een pastiche van een bepaald soort negentiende-eeuwse gruwelroman, tot stand gebracht met behulp van specifieke humoristische procédés, men de film als een bepaald type griezelfilm zonder dergelijke procédés ziet' (Beekman 1986, 7). Met andere woorden, de film wordt door de critici ervaren als een griezelfilm zonder ironie, het boek als een pastiche. ${ }^{10}$

Rosemarie Buikema en Lies Wesseling interpreteren De vierde man als gothic novel in hun inleiding over het gotieke in de twintigste-eeuwse Nederlandse literatuur (2006). Ze gaan in op de gotieke setting van de roman, Gerards ontdekking van Christines dode echtgenoten en zijn wrede martelfantasieen over Christine. Volgens Buikema en Wesseling is voor Gerard het leven met een vrouw een 'dekmiddel om ongestraft aan zowel zijn kinderlijke verlangens door een imaginaire moeder te worden bewonderd en vertroeteld, als aan zijn homoseksuele verlangens tegemoet te komen' (Buikema \& Wesseling 2006, 64). Ook besteden ze aandacht aan de vorm van de roman - een raamvertelling - die ze vergelijken met Henry James' gotieke novelle The Turn of the Screw (1898). Gerard vertelt de episode met Christine vele jaren later aan zijn Indische vriend Ronald. Net als in James' verhaal wordt de mogelijkheid om de ware toedracht te achterhalen in De vierde man gefrustreerd - door de constructie van de raamvertelling, en het schermen met gevonden documenten, afgeluisterde telefoongesprekken en oncontroleerbare bronnen. De kern van het verhaal blijkt leeg, stellen Buikema en Wesseling vast, als de verteller Gerard zich aan het eind van De vierde man al niet blijkt te kunnen herinneren hoe het kinderrijmpje ging dat de oude man in zijn droom zong: 'De sleutel tot de oplossing van het raadsel is dus alweer verloren, waarmee de kern als het ware uit de plot verdwenen is' (Buikema $\&$ Wesseling 2006, 64). Ze concluderen:

De $[\ldots]$ confrontatie met het zelf in verborgen hoeken en plaatsen van het huis wordt bij Reve [...] een verscheurende en angstaanjagende ervaring met het zowel begerenswaardige als angstaanjagende moederlichaam. Het aan zichzelf overgelaten zelf dreigt zich eerder te verbergen dan te ontplooien. In het geval van De vierde man wordt elke impuls van authenti-

\footnotetext{
${ }^{10}$ Overigens beweerde juist Gerard Soeteman, de scenarioschrijver van De vierde man, dat ironie in dit boek ontbrak: 'Reve heeft duidelijk een gewoon griezelverhaal willen schrijven. [...] De constructie is die van een gewoon en heel nadrukkelijk negentiende-eeuws griezelverhaal' (in Parool 23 maart 1983, geciteerd in Beekman 1986, 5).
} 
citeit bovendien ogenblikkelijk gecorrumpeerd door bijgedachten en perverse verlangens. Liefde verkeert ogenblikkelijk in wreedheid. Heteroseksualiteit verschijnt vooral als de maskerade van homoseksualiteit. (Buikema $\&$ Wesseling, 2006, 65-66)

Buikema en Wesseling stellen dat de naoorlogse Nederlandse gothic novel, die hier te lande de trekken krijgt van de homely gothic ${ }^{11}$, vooral te lezen is als een kritiek op de wederopbouw en de ideologie van maatschappelijke maakbaarheid. Ze bouwen daarmee voort op de stelling van pedagoog Ido Weijers dat in Nederlandse romans de huiselijkheidsideologie van na de oorlog wordt ontmanteld (Weijers 1991). Terwijl een groeiend leger deskundigen - onder hen psychologen, pedagogen en criminologen - het huis en het gezin als het fundament van de naoorlogse maatschappij beschouwen, de kern van waaruit vrijheid en zelfontplooiing mogelijk worden, komen romanschrijvers als Hermans, Reve en Blaman tot diametraal tegenovergestelde conclusies in hun werk. ${ }^{12}$ De gotieke vertelling is een buitengewoon geschikt medium om de ambivalente bescherming die huis en haard bieden vorm te geven, aldus Buikema en Wesseling. Ze lezen Reve als een van de naoorlogse Nederlandse auteurs die 'door middel van het repertoire van de gotieke vertelling kritisch commentaar leveren op het streven naar verlichting, vooruitgang, zelfontplooiing en emancipatie.' (Buikema $\&$ Wesseling 2006, 66).

In dit hoofdstuk wil de verschijningen van het gotieke in De vierde man nog eens in detail analyseren. Wanneer verschijnt het, welk effect sorteert het in de roman en wat doet het gotieke als het gaat om ambivalenties ten aanzien van sekse en seksualiteit? Ik zal Buikema en Wesselings thematische en formele analyse van De vierde man, als gotieke (raam)vertelling waarin elke impuls tot authenticiteit gecorrumpeerd wordt, op twee punten aanscherpen. Ten eerste denk ik dat het kader van de naoorlogse huiselijkheidsideologie niet het meest voor de hand ligt bij de interpretatie van De vierde man. De roman draagt duidelijk de sporen van ideeën over de seksuele revolutie en de tweede feministische golf, dus van de jaren zeventig. Dat is voor mij aanleiding om juist die emancipatievertogen centraal te stellen bij mijn analyse. Het cultural work dat door het gotieke verricht wordt in De vierde man, zo wil ik betogen, concentreert zich rond spanningen rond man-vrouwverhoudingen en rond seksueel gedrag: rond de vraag hoe je je als man of vrouw in bed dient te gedragen. Op

\footnotetext{
${ }^{11}$ Zie Botting (1996) 113-135. Zie ook hoofdstuk 2, noot 23.

${ }^{12}$ Zie ook Ruiter \& Smulders (1996), 281-285.
} 
die terreinen worden in De vierde man traditionele en moderne opvattingen tegenover elkaar gezet, door middel van het gotieke.

Ten tweede mis ik bij Buikema en Wesseling aandacht voor de rol van ironie en parodie. Niet alleen inhoudelijk, maar ook op het niveau van de stijl (de vele puntjes, de woorden die tussen aanhalingstekens staan, de ironische zelfreflectie, de parodie op andere genres) valt niet uit te maken wat serieus genomen moet worden en wat niet, wat authentiek is en wat niet. De corrumpering van authenticiteit in De vierde man spitst zich toe op de corrumpering van seksuele identiteit, die sinds eind negentiende eeuw vaak als de kern van het zelf wordt beschouwd. ${ }^{13}$ Volgens filosoof Charles Taylor is het streven naar authenticiteit sinds de achttiende eeuw (door het werk van filosofen als Herder en Rousseau) een typisch onderdeel van moderne subjectiviteit geworden (Taylor 1991). Aan moderne individuen wordt een moreel appèl gedaan om authentiek te zijn, dat wil zeggen, om zichzelf te zijn, om zichzelf te verwezenlijken. Die moderne ethic of authenticity wordt in De vierde man via een specifieke parodie ondermijnd: een parodie van heteroseksuele mannelijkheid. Ik begin met een belangrijke bron van het gotieke in De vierde man: Christine.

\section{DE WEDEROPSTANDING VAN DE FEMME FATALE}

Christine is een hedendaagse reïncarnatie van de femme fatale, de erotische en fatale muze die geassocieerd wordt met macht en geweld. Volgens Mario Praz (1970) leverde Matthew Lewis' gotieke klassieker The Monk (1796) het prototype van de fatale vrouw: het personage Matilda, die als Satans instrument de val van de monnik Ambrosio veroorzaakt. ${ }^{14}$ Bram Dijkstra beschreef de enorme belangstelling voor de fatale vrouw in de negentiende-eeuwse beeldende kunst en in de twintigste-eeuwse populaire cultuur (Dijkstra 1986, 1996). De femme fatale is in de populaire verbeelding verwant geworden aan de vampier: denk aan de mooie vampiervrouwen in Dracula die Jonathan Harker in Dracula's Transsylvanische kasteel proberen te verleiden. Het woord 'vamp' is volgens Van Dale een vrouw die erop uit is 'mannen onder haar bekoring te brengen en te exploiteren'. Dijkstra beschouwt de femme fatale als een product van misogynie, een uitdrukking van de angst van mannen voor autonome vrouwen: 'By 1900 the vampire had come to represent woman as the personification of everything negative that linked sex, ownership, and money' (Dijkstra 1986, 351).

\footnotetext{
${ }^{13}$ Zie Foucault (1984) voor de geschiedenis van dit idee.

${ }^{14}$ Reve kende Praz' boek overigens goed, zie Beekman en Meijer (1973), p. 192-193.
} 
Het is een interpretatie waar feministen opvallend vaak mee hebben ingestemd, al is het bepaald geen positief imago. Elizabeth Bronfen (2004) brengt in haar lezing van de femme fatale (in de film noir) enige nuances aan. Volgens Bronfen wordt de femme fatale heen en weer geslingerd tussen noodlot (fate) en agency, ze is een tragische figuur die niet alleen fataal is voor de man die ze verleidt, maar ook voor zichzelf:

She knows all along that she is fated and can, therefore, turn what is inevitable into a source of power. Indeed, the classic femme fatale has enjoyed such popularity because she is not only sexually uninhibited, but also unabashedly independent and ruthlessly ambitious, using her seductive charms and her intelligence to liberate herself from the imprisonment of an unfulfilling marriage. (Bronfen 2004, 106)

Enerzijds is zij volgens Bronfen inderdaad een product van de mannelijke fantasie, die een fascinatie voor seksueel dominante vrouwen en angst voor vrouwelijke overheersing uitdrukt, maar anderzijds geeft zij ook ruimte aan de articulatie van een vrouwelijk verlangen dat hem (de noir held) kan betreffen.

Christine is een economisch en seksueel autonome vrouw, zoals het een fatale vrouw betaamt: zij verdient haar eigen brood, bezit een huis en is een zelfbewuste minnares die niet terugdeinst voor een slippertje - ze verleidt Gerard terwijl ze een relatie heeft met Herman. Dat zou geïnterpreteerd kunnen worden als een teken van verlangen van haar kant. Doordat de focalisatie echter nooit bij haar ligt valt zij moeilijk te zien als een actief-verlangend personage. Gerards angst en fascinatie staan op de voorgrond, waardoor zij vooral een product van zijn (bij tijd en wijlen nogal misogyne) ${ }^{15}$ fantasie blijft. Gerard is van meet af aan bezig met de vraag naar de machtsverhoudingen tussen hem en Christine. De gedachte dat Christine hem in haar macht heeft, windt hem op. Dat blijkt al meteen al in de pauze van voorleesavond, als op maar liefst vijf verschillende manieren wordt gezegd dat Christine over zijn vergoeding gaat:

"Deze dame", sprak hij [een bestuurslid, AA], is onze penningmeester. Of eigenlijk penningmeesteres, zou ik moeten zeggen. Zij betaalt $U$ : van haar krijgt U Uw pekulanten, zal ik maar zeggen." "Jij betaalt mij dus", mom-

\footnotetext{
${ }^{15}$ Gerard stelt zelf overigens dat hij juist niet misogyn is: "[ik] koesterde [...] jegens vrouwen geenszins - zoals dat helaas bij vele van mijn "gevoelsgenoten" wèl het geval was - gevoelens van verachting, haat of angst'. (35-36) Paginanummers verwijzen naar citaten uit Reve (1981).
} 
pelde ik bij mijzelf. Ik begreep niet waarom die vier woorden mij op de één of andere manier opwonden. (15)

Niet alleen de gedachte dat Christine hem in zekere zin bezit, als penningmeesteres van het literaire genootschap, maar ook dat zij bezittingen heeft, met andere woorden dat zij rijk is, vindt Gerard in eerste instantie opwindend. De onduidelijkheid over de vraag of het grote huis van haar is, zet zijn fantasie aan het werk: 'bewoonde Christine [...] hier een huurkamer of was zij beheerster, wat zeg ik, eigenaresse van deze gehele onroerende drie-eenheid?' (25). De vraag of zij getrouwd is, is gekoppeld aan de vraag of het huis van haar is: 'haar maatschappelijke staat, die kende ik niet, noch wist ik van wie het kapitale huis was waarin ik logeerde' (37); en: 'zij wàs hier dus op één of andere manier de baas' (43). Ten slotte weet hij zeker dat zij de eigenaar is: 'Christine ontsloot in de hal, met een sleutel aan een bos die ze bij zich droeg - het zoveelste bewijs dat dit haar eigen huis was - de deur [...]'(58). Het idee dat zij rijk is past in het romantische plot dat Gerard meteen begint te verzinnen, van arme jongen (Gerard is naar eigen zeggen een 'geboren armoedzaaier' (25)) die een rijke vrouw aan de haak slaat.

Gerard wordt heen en weer geslingerd door het verlangen Christine te bezitten en het verlangen door haar bezeten te worden. Bij het betreden van Christines huis realiseert hij zich dat hij al in termen van bezit over haar denkt, als “"mijn” Christine' (25). Zo manoeuvreert hij zich al in de positie van heer des huizes voordat hij de drempel over is. Nu eens wil hij degene zijn die de dienst uitmaakt: 'Christine gaf iets om mij, zoveel was zeker, en had mij macht over haar gegeven. Ze was mijn eigendom, in ieder geval deze nacht...' (73). Dan weer wil hij haar bezit worden: 'Ja, haar ankleedpop worden, haar, haar...Ik duwde geschrokken het Italiaanse woord weg, dat op de drempel van mijn gedachten lag.' (58) - het halfbewuste woord dat de lezer wordt geacht aan te vullen is natuurlijk gigolo, oftewel een jongen die wordt onderhouden door een vrouw. De associatie met prostitutie is niet ver weg - Gerard wordt immers door Christine betaald. Het gevoel dat zij hem in haar macht heeft wordt echter al snel bedreigend: 'De gedachte dat ze zich nu van mij kon ontdoen zonder dat ik enig verhaal kon doen gelden, kwetste mijn manlijke trots en joeg mijn bloed op' (59). Soms overheerst juist de gedachte dat hij een beschermer nodig heeft. Als Gerards haar door Christine geknipt is en in de spiegel kijkt denkt hij: 'ik moest wel blind zijn als ik het in de spiegel niet zag: geen man, ik, maar een levensbang jongetje dat het zonder volwassen bescherming niet kon stellen.' (57). De voortdurende en pijlsnelle omkering van rollen in De vierde man zet traditionele man-vrouwverhoudingen onder druk. 
Gerards mengeling van angst en verlangen wordt het meest zichtbaar in de bedscènes. Na de eerste keer seks, waarvan Christine lijkt te hebben genoten, kan Gerard de slaap niet vatten. Hoewel hij zichzelf voorhoudt dat hij zich veilig kan voelen - naast een vrouw in een comfortabel bed - benauwt de duisternis hem. Hij schrikt van een klapperende deur en heeft het gevoel dat er iets niet klopt. Met andere woorden, juist op het moment dat zijn romantische heteroseksuele fantasie verwezenlijkt lijkt, wordt hij door een gotieke dreiging beklemd. Als hij uiteindelijk toch in slaap valt heeft hij een nachtmerrie die een vervolg is op de droom die hij onderweg naar $\mathrm{V}$. heeft gehad, waarin hij naderend gevaar voelde. Badend in het zweet wordt hij wakker, en vraagt zich af of hij van Christine iets te vrezen heeft:

Had zíj mij misschien die droom gestuurd, terwijl ze zich slapende hield? ...Ja, als ze een heks was, of een vampier...[...] Neen, geen vampier, overwoog ik, want aan haar hoektanden had ik niets bizonders gezien, en ze had me ook niet, bij ons liefdesspel, in mijn keel gebeten om mijn bloed te drinken...Wel jammer eigenlijk, dat ze dat niet gedaan had... (40-41)

Zodra Gerard de gevoelde dreiging expliciteert - die ik zou willen omschrijven als de angst om overmeesterd te worden - slaat die om in seksueel verlangen. De gedachte dat Christine misschien een heks is, die gemarteld moet worden om tot een bekentenis gebracht te worden, windt hem zozeer op, dat hij zich letterlijk opnieuw op haar werpt:

Als ze mij nù afwees..., mij nù de toegang weigerde, dan...zoude dat haar dood betekenen...: dan was het bewijs geleverd, dat zij in tovertrance lag, en een heks was...dan zouden mijn vingers, mijn duimen, zich om haar keel sluiten...Christine gaf zich, half wakker of niet, glimlachend, zelfs met een zekere verrukking naar het scheen, aan mij over... (41)

Gerard wordt dus gedreven door tegengestelde impulsen: de gotieke elementen (zoals zijn nachtmerrie, de associatie met een vampier en een heks) die hem angst aanjagen, wakkeren tegelijkertijd zijn verlangen aan. Daarin lijkt een zekere SM-dynamiek te herkennen: het seksuele spel dat op machtsverschillen gebaseerd is.

De vierde man draait om bezitten en bezeten worden, en het gotieke dient om de spanning tussen die twee posities vorm te geven. Christine wordt in Gerards verbeelding een verslindende minnares. Zijn ontdekking dat Christine driemaal weduwe is vormt voor hem de bevestiging van zijn onheilspellende 
dromen: dat is teveel om toevallig te zijn, aldus Gerard. Als hij vervolgens constateert dat hij op Christines dode echtgenoten lijkt - een unheimliche ervaring van de eerste orde - lijken zijn vermoedens helemaal bevestigd. Toch komt nergens in deze roman onomstotelijk vast te staan dat zij echt gevaarlijk is; het gebeurt allemaal in Gerards hoofd.

De episode met Laurens, de jongen die hij oppikt als hij op Christines huis past, biedt hier goed vergelijkingsmateriaal. Net als bij Christine vat Gerard de verhouding met hem op in termen van bezit: hij roept bij Gerard 'zowel vertedering als een brute, met verachting gemengde bezitsdrift' (110) op. Er is echter een belangrijk verschil: met Laurens neemt Gerard vanzelfsprekend de 'bezittende' positie in. Hij voelt zich niet bedreigd en is vanzelfsprekend de baas. Voorzover het gotieke zich in die scène manifesteert, verwijst dat naar Christine: Gerard ontdekt het doosje met de foto's van Christines eerdere echtgenoten als hij met Laurens in bed ligt en per ongeluk met zijn schouder een tijdschrift van de plank stoot ('een blauwe, gekartonneerde jaargang of jubileumuitgave van Coiffure uit 196*, van de Kappersbond'). Ook de naam van Laurens' operettekoor 'Het vrolijke Weeuwtje' is een verwijzing naar Christine. ${ }^{16}$

Via het femme fatale motief gaan sentimenteel-romantische clichés over man-vrouwverhoudingen, met de man als redder en beschermer van een hulpeloze vrouw, op de schop. Het levert een over-the-top machtsspel tussen Gerard en Christine op dat het romantische plot ondermijnt. Het romantische plot beantwoordt de egalitaire en wederkerige vraag 'krijgen ze elkaar' altijd met ja, maar dat antwoord is hier uitgesloten. De machtsstrijd wordt zo expliciet gemaakt dat die het karakter krijgt van een parodie. Tegelijkertijd krijgt het femme fatale motief in De vierde man een ironische draai. Bronfen stelde dat de fatale vrouw gewoonlijk de vrouw is die de brave burgerman verleidt, waarbij ze zelf ten onder gaat. $\mathrm{Zij}$ is dus degene die - door haar seksuele macht - het huwelijk ondermijnt en daar uiteindelijk voor gestraft wordt. Het ironische van De vierde man is dat Christine voor Gerard in eerste instantie de belofte van een burgerlijk bestaan personifieert, louter door het feit dat zij een vrouw is. Voordat ik de parodie die Gerard opvoert met Christine nader analyseer, ga ik in op de verhouding tussen het komische en het gotieke. Wat betekent het als ik De vierde man een comic gothic noem? Kan een gotieke roman eigenlijk wel komisch zijn?

\footnotetext{
${ }^{16}$ De populaire operette Die Lustige Witwe (1905) van Franz Lehár gaat over de zoektocht van de zelfbewuste, rijke weduwe Hanna naar een man. Haar eerste echtgenoot, een oude rijke bankier, overleed in de huwelijksnacht.
} 


\section{HET GOTIEKE EN HET KOMISCHE}

Sinds haar ontstaan, eind achttiende eeuw, is gotieke fictie in de eerste plaats geassocieerd met het genereren van angst. David Punter noemde het gotieke in zijn lange tijd toonaangevende studie niet voor niets The Literature of Terror (1980). Een relatie tussen het gotieke en het komische ligt niet voor de hand. Toch blijkt bij nadere beschouwing dat de twee fenomenen elkaar niet hoeven uit te sluiten. In Gothic and the Comic Turn (2005), de eerste systematische studie naar gotiek en humor, wijzen Avril Horner en Sue Zlosnik erop dat Punter te weinig oog heeft voor het hybride karakter van het gotieke, dat komische effecten kan veroorzaken. ${ }^{17}$ De hybriditeit van de gotieke roman - met zijn verschillende tekstsoorten, botsende registers, en mengeling van melodrama en horror - maakt volgens hen een comic turn mogelijk ten overstaan van angst. Die treedt vaker op dan je zou verwachten, ook in romans die eerder altijd als 'serieuze' gothic gelezen zijn, zo laten ze zien. Bovendien kan wat een bron van angst was voor de achttiende-eeuwse lezer een bron van vermaak zijn voor de hedendaagse lezer, met andere woorden, in een definitie van het gotieke die alleen het angstaanjagende aspect benadrukt, ontbreekt de historische veranderlijkheid van angst, en de mogelijkheid dat iets engs in iets komisch kan veranderen. ${ }^{18}$ Bovendien blijkt de grens tussen gotiek of parodie op gotiek niet altijd even scherp te trekken. Dat blijkt bijvoorbeeld uit het feit dat Jane Austens Northanger Abbey (1818) in de hedendaagse kritiek nu eens als burleske parodie op het gotieke wordt getypeerd, en dan weer als een gothic novel die met gotieke middelen het genre subtiel ondermijnt. ${ }^{19}$

\footnotetext{
${ }^{17}$ Er bestonden al wel wat verspreide artikelen waarin het komische in de gotieke roman aandacht krijgt. Horner \& Zlosnik verwijzen naar Stevick (1979), Vincent (1983), Lewis (1989), Sage (1994), Wolfreys (2002). Zie ook Hogle (1994).

${ }^{18}$ Voor een bespreking van angst als historisch veranderlijk fenomeen, zie Bourke (2005). Zij geeft onder andere het voorbeeld van de reële vrees die eind negentiende eeuw bestond voor levend begraven worden. Sedgwick noemt levend begraven worden als een van de belangrijkste bronnen van gotieke spanning (Sedgwick 1986, 5 e.v.). In Engeland leidde deze angst in 1899 tot de oprichting van de Association for the Prevention of Premature Burial (Bourke 2005, 33-43, p. 42 over de Association). Wat ten grondslag lag aan deze angst was een gebrek aan vertrouwen in het vermogen van medici om het overlijden ondubbelzinnig vast te stellen. Hoe komisch zo'n vereniging ook mag lijken voor de $21^{\mathrm{e}}$-eeuwse lezer, de hedendaagse angst voor het voortijdig verwijderen van donororganen berust in feite op hetzelfde wantrouwen: weten medici wel echt wanneer iemand dood is? De angst blijft, maar is cultuur-historisch bepaald.

${ }^{19}$ Horner \& Zlosnik noemen als voorbeeld van Austen-als-gothic Johnson (1988). Zie ook Hutcheon (1985), p. 79, die Gilbert \& Gubar (1979) aanhaalt, en Howard (1994).
} 
Horner en Zlosnik stellen dat de centrale functie van het gotieke weliswaar ligt in de hang naar grensoverschrijdingen en de obsessie met het kwaad en geweld, maar dat sluit volgens hen een comic turn niet uit. Ze beschouwen het gotieke als een antwoord op de moderne conditie, die ze vooral typeren als een verlies aan transcendentie. Dat is op zichzelf niets nieuws, maar wat Horner en Zlosnik benadrukken is dat het een antwoord is met gemengde gevoelens. Het komische moment in de gotiek is niet de 'corruptie' van een serieus genre, maar biedt een positie voor scepsis over het moderne verlies en de nostalgie die ermee gepaard gaat. Scepsis impliceert reflexiviteit, en juist het vermogen tot zelfreflectie is kenmerkend voor het moderne subject aldus Horner en Zlosnik: 'The comic within the Gothic foregrounds a self-reflexivity and dialectical impulse intrinsic to the modern subject' (Horner \& Zlosnik 2005, 4). ${ }^{20}$

De komische wending in de gothic krijgt vaak gestalte via parodieën, die Horner en Zlosnik daarom beschouwen als een sleutelelement voor comic gothic. Ze gebruiken de term parodie in de zin van Simon Dentith (2000). Hij vat de parodie, oftewel een imitatie van een culturele tekst of vertoog, op als een spectrum van culturele praktijken die in meer of mindere mate spottend en/of humoristisch zijn. ${ }^{21}$ Daarbij is het van belang om twee soorten parodie te onderscheiden: het doelwit van spot kan ofwel de geïmiteerde tekst zijn, of, via de imitatie van een tekst, bepaalde opvattingen in de wereld buiten de tekst. Er kan niet op voorhand worden gezegd wat het cultural work is dat door parodie wordt verricht, dat kan zowel normondermijnend als normbevestigend zijn. Juist vanwege die tweede vorm van parodie benadrukken Horner en Zlosnik het belang van een gecontextualiseerde lezing, de noodzaak om parodie in haar historische en culturele moment te plaatsen.

Een parodie kan zich dus kritisch verhouden tot een brontekst, die belachelijk maken, maar een parodie kan ook de autoriteit van een oudere tekst gebrui-

\footnotetext{
${ }^{20}$ Horner en Zlosnik zien in de komische gotiek 'the beginning of a deconstructionist turn inherent within modernity' (Horner \& Zlosnik 2005, 3). Zonder me te willen begeven in een definitiediscussie merk ik op dat komische gotiek daarmee een postmodern moment in de moderniteit lijkt in te houden. Zelfreflexieve fictie, of metafictie - en parodie is op te vatten als een zelfreflexieve techniek - geldt als een van de karakteristieke kenmerken voor postmodernisme. Reves werk is zelden in verband gebracht met postmodernisme (uitzonderingen zijn Smulders (1999), Ruiter \& Smulders (1996), maar daar is zeker aanleiding voor. In ieder geval is in De vierde man zo'n postmoderne, parodische zelfreflexiviteit alom aanwezig.

${ }^{21}$ Dentith maakt bijvoorbeeld geen scherp onderscheid tussen pastiche en parodie; hij beschouwt de pastiche als een van de verschijningsvormen van parodie, in tegenstelling tot Fredric Jameson die een beroemd geworden essay schreef waarin juist het verschil tussen pastiche en parodie bepalend is (Jameson 1984), dat overigens om verschillende redenen fel is bekritiseerd, onder anderen door Hutcheon (zie Dentith 2000, 156 e.v.).
} 
ken om zich kritisch te verhouden tot de wereld. ${ }^{22}$ Vertaald naar parodie van het gotieke kan dat inhouden dat de draak gestoken wordt met het gotieke genre, waarbij de brontekst kritisch tegen het licht wordt gehouden, zoals dat eind achttiende eeuw bijvoorbeeld gebeurde in spottende gedichten over gothic novels als formulefictie. ${ }^{23}$ De andere mogelijkheid is dat via ironische imitaties van het gotieke een kritische boodschap over de 'wereld' wordt overgebracht. Horner en Zlosnik geven het voorbeeld van Angela Carters parodieën op gotieke verhalen, die te lezen zijn als een kritisch commentaar op hedendaagse man/vrouwverhoudingen.

In de hoofdstukken die Horner en Zlosnik wijden aan romans van respectievelijk vrouwelijke auteurs - zoals Margaret Atwood en Fay Weldon - en mannelijke auteurs - Iain Banks en Patrick McGrath - treffen ze voornamelijk gotieke parodieën aan die fungeren als kritiek op de 'wereld', en dan met name op het gebied van sekseverhoudingen (Horner \& Zlosnik 2005, Hs. 5 en 6). Terwijl de vrouwelijke auteurs parodieën op de gothic aanwenden als een krachtig instrument om zich ironisch te distantiëren van hedendaagse vertogen over vrouwelijkheid, gebruiken de mannen gotiek en parodie om vraagtekens te stellen bij wat het betekent om een man te zijn in de jaren tachtig, aldus Horner en Zlosnik. Parodieën van gotieke verhalen fungeren met andere woorden als een productief vehikel voor maatschappijkritiek. Met de lezingen van gotieke romans uit de jaren tachtig door Horner en Zlosnik in het achterhoofd ben ik geïnteresseerd in de vraag wat de parodie van het gotieke in De vierde man teweeg brengt op het gebied van mannelijkheid en vrouwelijkheid. De vraag wat het betekent om een man te zijn in de jaren tachtig zal ook voor mijn analyse cruciaal blijken. De genreparodie die De vierde man óók is zal ik in mijn interpretatie betrekken.

\section{PARODIE VAN EEN HETEROBESTAAN}

De vierde man zet in met een verlangen dat de CPNB nauwelijks aanstootgevend kon vinden: Gerard fantaseert namelijk over de mogelijkheid dat hij bij

\footnotetext{
${ }^{22}$ Zie Dentith (2000), 16-19.

${ }^{23}$ Een voorbeeld van zo'n satire: 'Take- an old castle, half of it ruinous / A long gallery, with a great many doors,/ Some secret ones./ Three murdered bodies, quite fresh./ As many skeletons, in chest and presses / An old woman, hanging by the neck, / with her throat cut. /Assassins and desperados, quant.suff. / Noises, whispers, and groans, threescore at least. / Mix them together, in the form of three volumes, / To be taken at any watering places before going to bed.' (1798) (geciteerd in Clery \& Miles 2000, 182-184).
} 
Christine zou kunnen intrekken, dat hij met haar een leven als andere 'fatsoenlijke, burgerlijke mensen' (48) zou kunnen leiden. Bij hun eerste ontmoeting tijdens de voorleesavond, overweegt hij nog slechts de mogelijkheid om met Christine naar bed te gaan, maar de volgende ochtend fantaseert hij al over een leven met haar, waarin hij zou kunnen schrijven, terwijl zij voor hem zou zorgen. Ze zou elke dag zijn schrijftafel afstoffen, en weliswaar 'geen letter begrijpen van wat ik schreef, maar ze zoude zulks evenmin voorwenden' (48). Christine zou Gerards maatschappelijke onaangepastheid - gelegen in het feit dat hij schrijver en homoseksueel is - kunnen compenseren. Het vooruitzicht van zo'n burgerlijk bestaan als man en vrouw roept zowel gevoelens van macht, geborgenheid als opwinding bij hem op. De wetenschap dat hij een pose aanneemt weerhoudt hem er niet van zijn fantasie met verve uit te leven.

Gerard leeft zich letterlijk in in de rol van heteroseksuele man die een vrouw verleidt. Hij beschrijft zijn eigen handelingen herhaaldelijk in termen van filmscènes: 'Ik trok haar naar mij toe, sloeg mijn armen om haar heen en kuste haar, precies als in een film, met langzaam toenemende druk op haar mond' (28). Hij gedraagt zich als een echte acteur: 'de camera behoefde de scène niet over te doen: op deze manier werden de draaikosten gedrukt.' (73). ${ }^{24}$ Deze zelfobservaties benadrukken dat hij een rol speelt, en dat hij zich bewust is van die acteerprestatie. Zijn optreden komt echter authentiek over. Christine lijkt tevreden, en zelf heeft hij er zowaar ook wel plezier in. Hij constateert verrast doch tevreden dat hij seksueel opgewonden raakt.

Volgens Horner en Zlosnik zijn vooral incongruenties aan de oppervlakte van de tekst verantwoordelijk voor komische effecten in de gothic - melodramatische momenten, overdrijvingen en registerwendingen. ${ }^{25}$ De vierde man zit vol met dat soort momenten en registerwendingen. Gerards imitatie van een heteroseksuele man is een parodie, die een komische uitwerking heeft. Het komische zit hem in Gerards overdrijvingen die afgewisseld worden met relativeringen - hij realiseert zich meermalen dat zijn fantasie, 'mijn verhitte verbeelding' (30) op hol slaat. Ook de nuchtere bijgedachten bij romantisch aandoende beschrijvingen zijn komisch: 'We stonden onder de kruin van een boom of grote heester - "Is Uw plant een boom of heester? Zo ja, ga dan naar blz 13"met enorme witte, parelmoeren bloesems'(27). Een ander komisch effect wordt veroorzaakt door het verschil in kennis tussen de lezer en Christine - een vorm van dramatic irony.

\footnotetext{
${ }^{24}$ In Oud en eenzaam heeft hoofdpersoon Gerard ook het gevoel dat zijn relatie met Jane Raleigh namaak is. Hij bedenkt zich dat hij 'voor man' kan spelen (70), zij is bovendien actrice.

${ }^{25}$ Voor het belang van oppervlaktes in de gothic, zie ook Sedgwick (1986), 12.
} 
De lezer uit 1981 kent Gerard Reve op dat moment waarschijnlijk als de bekendste homoseksuele schrijver van Nederland. Maar ook de lezer die van dat biografische feit niet op de hoogte is, weet in ieder geval dat Gerard in het vertelheden van de raamvertelling een homoseksuele relatie heeft, met de eerder genoemde Ronald. Het ingebedde verhaal is begin jaren zestig gesitueerd, en speelt zich af, zo is de suggestie, vóórdat het grote publiek op de hoogte was van Gerards homoseksualiteit - er is bijvoorbeeld geen aanwijzing dat de bezoekers van de lezing in V. daarvan een vermoeden zouden kunnen hebben. ${ }^{26}$ De lezer weet zo wat Christine niet weet - dat Gerard eigenlijk homo is - en neemt hem daarom waarschijnlijk minder serieus als hetero. Bovendien is de botsing tussen burgerlijkheid en anti-burgerlijkheid grappig. Net zoals Reve burgerlijkheid ter discussie stelde (door zijn homoseksualiteit maar ook door zijn werk, denk maar aan De Avonden), maar even goed een vurig pleidooi kon houden voor het koningshuis of de middenstand, toont zijn personage Gerard, type romantische kunstenaar, hier een verlangen naar een burgerlijk bestaan. Dentith schrijft dat parodie een manier is om, door het evoceren van het verleden, het heden een dubbele lading te geven, oftewel "to "double-code" the understanding of the present' (Dentith 2000, 183). De schrijver Reve doet eigenlijk het omgekeerde: hij geeft het verleden, oftewel zijn twintig jaar jongere alter ego Gerard, een dubbelzinnige lading, die de lezer uit de jaren tachtig kan ontcijferen door zijn/haar kennis over de hedendaagse Reve te mobiliseren. Daardoor heeft Gerards heteroseksuele verhouding een komisch effect; maar ook doordat hij er met distantie over schrijft. ${ }^{27}$

Gerards pogingen om met een vrouw te verkeren, om zich als hetero te gedragen, kunnen gelezen worden als een vorm van mimicry, als een vorm van zelfbewuste imitatie. De filosofe Judith Butler spreekt - een kleine tien jaar ná het verschijnen van De vierde man - in die termen over wat zij de performance of gender noemt (Butler 1999 [1990]). Butler bedoelt daarmee, zo licht Annemie Halsema in haar inleiding op Butlers werk toe, dat 'alle verschijningsvormen van gender, dus ook man- en vrouw-zijn, in feite performances zijn' (Halsema $2000,15)$. Het sekseverschil is volgens Butler geen natuurlijk gegeven, maar een

\footnotetext{
${ }^{26}$ Reves publieke coming out vond plaats in 1963 met $O p$ weg naar het einde, dus rond zijn veertigste. Gerard in De vierde man loopt tegen de veertig, zie noot 37.

${ }^{27}$ Overigens was Reve van 1948 tot 1959 getrouwd met de dichteres Hanny Michaelis. Die wetenschap zou het humoristische effect weer kunnen verminderen, maar geen van de recensenten refereerde aan Reves eerdere heteroseksuele verhouding. Dit heterohuwelijk was op dat moment dus geen referentie meer.
} 
verschil dat betekenis krijgt in normatieve praktijken. ${ }^{28}$ Anders gezegd, opvattingen van het lichaam worden gekleurd door maatschappelijke en culturele normen die sommige lichaamsopvattingen mogelijk maken en andere veel minder (transgender zijn ligt bijvoorbeeld niet voor de hand). Andersom kunnen die maatschappelijke mogelijkheden worden uitgebreid door nieuwe lichaamsopvattingen (zoals transgender). ${ }^{29}$ Omdat gender volgens Butler geen natuurlijk gegeven is, moet gender steeds opnieuw worden uitgevoerd en opgevoerd om bevestigd te worden. Daarmee is niet gezegd dat een individu zich zomaar kan onttrekken aan (het herhalen van) gendernormen - daarvoor is de maatschappelijke norm om herkenbaar te zijn als een bepaald gender te sterk. De noodzaak tot het herhalen van gender biedt echter wel ruimte voor kritische, ironische, of hyperbolische imitaties, oftewel parodieën van gender. Volgens Butler laten nadrukkelijke parodieën van gender, zoals travestie en butch/femme-praktijken, zien dat het zogenaamde origineel, de 'echte' man of vrouw, zelf een effect is:

The parodic repetition of gender exposes [...] the illusion of gender identity as an intractable depth and inner substance. As the effects of a subtle and politically enforced performativity, gender is an 'act', as it were, that is open to splittings, self-parody, self-criticism and those hyperbolic exhibitions of 'the natural' that in their very exaggeration, reveal its fundamentally phantasmatic status. (Butler 1999, 146-147). ${ }^{30}$

Voor mijn interpretatie van Gerards gedrag in De vierde man is deze notie van parodie zeer toepasselijk. Als Gerard Christine verleidt, speelt hij een heteroseksuele man, wat zoals gezegd nadrukkelijk als een rol, een performance wordt gepresenteerd. Hij voert een parodie op, maar het is niet zozeer een parodie van gender (hij is immers geen man die een vrouw speelt, zoals een travestiet), als wel een parodie van seksualiteit: hij is een homoseksueel die een heteroseksueel

\footnotetext{
${ }^{28}$ Butler maakt dan ook geen principieel onderscheid tussen sekse en gender. Haar definitie van gender in Undoing gender (2004) luidt: 'Gender is the apparatus by which the production and normalization of masculine and feminine take place along with the interstitial forms of hormonal, chromosomal, psychic, and performative that gender assumes. En: 'Gender is the mechanism by which notions of masculine and feminine are produced and naturalized, but gender might very well be the apparatus by which such terms are deconstructed and denaturalized. (Butler 2004, 42).

${ }^{29}$ Met dank aan Annemie Halsema.

${ }^{30}$ In haar latere werk benadrukt Butler dat afwijken van de gendernorm meestal niet als speelse parodie ervaren wordt door mensen die de afwijking noodgedwongen belichamen (zoals transgenders en interseksuelen), integendeel. Ze lijkt het woord parodie daarom inmiddels te vermijden. Zie vooral Butler (2004).
} 
speelt; hij is als het ware een 'travestiet' van seksualiteit. Al hoeft hij zich niet te verkleden, hij stapt wel in een andere rol.

Op het niveau van de tekst heeft deze parodie van heteroseksualiteit twee gevolgen: om te beginnen weet Gerard Christine te verleiden. Hij slaagt dus als heteroseksueel - Christine herkent de parodie niet als zodanig. Ten tweede roept de parodie bij Gerard vragen op over zijn eigen mannelijkheid. Hij weet niet goed hoe hij zich als man dient te gedragen: 'Moest ik nu de wanhopige aanbidder gaan spelen, of het onverzadigbare, brute dier dat man heette?' (59). $\mathrm{Nu}$ eens constateert hij dat hij een man is - 'ik gevoelde in mijn kruis dat ik wel degelijk een man was' (25), dan twijfelt hij daar weer aan: 'Ik keek naar Christine en vroeg mij nu niet meer af, wat voor een soort vrouw zíj, maar wat voor een soort man ík was.' (31).

Kortom, zijn heteroseksuele parodie roept bij Gerard de vraag op 'wat voor soort man ben ik?'. Zijn rol als heteroseksueel leidt tot wat Butler een gendercrisis zou noemen, een crisis over zijn mannelijkheid - zij het met een knipoog. Dat is verrassend vanuit het perspectief van Butler, die ervan uitgaat dat juist niet-heteroseksuele praktijken de stabiliteit van gender ter discussie kunnen stellen. ${ }^{31}$ Butlers centrale vraag is namelijk, zoals ze nog eens uitlegt bij het tienjarig jubileum van Gender Trouble:

How do non-normative sexual practices call into question the stability of gender as a category of analysis? How do certain sexual practices compel the question: what is a woman, what is a man? If gender is no longer to be understood as consolidated through normative sexuality, then is there a crisis of gender that is specific to queer contexts? (Butler 1999, xi, mijn cursivering)

Heteroseksualiteit is met andere woorden de normatieve praktijk die ertoe bijdraagt dat gender stabiel blijft. ${ }^{32}$ Voor Gerard is het omgedraaid. Zodra hij zich als heteroseksueel gaat gedragen - normbevestigend gedrag, zou je denken -

\footnotetext{
${ }^{31}$ Butler geeft als voorbeeld hoe de verschijning van een butch lesbo ideeën over vrouwelijkheid kan ondermijnen. Overigens wil ze niet beweren dat niet-normatieve praktijken per definitie subversief zijn: '...subversive performances always run the risk of becoming deadening clichés through their repetition, and most importantly, through their repetition within commodity culture where "subversion" carries market value. The effort to name the criterion for subversiveness will always fail, and ought to' (Butler 1999, xxi).

32 Een voorbeeld van het tegenovergestelde is het stereotype:"echte' mannen houden niet van mannen'. Daarin wordt de definitie van mannelijkheid afhankelijk gemaakt van seksuele voorkeur: homoseksualiteit destabiliseert mannelijkheid.
} 
komt zijn mannelijkheid ter discussie te staan. De vraag naar wat voor man hij is komt namelijk helemaal niet bij hem op in een homoseksuele context, als hij later in de roman een korte affaire met Laurens heeft. In Butlers termen: de niet-normatieve seksuele praktijk leidt dan niet tot destabilisering van gender, althans niet van Gerards gender. In het contact met Laurens staat zijn mannelijkheid geen moment ter discussie. Dan is hij vanzelfsprekend een man, een vrijwel ongemarkeerde categorie, en vraagt hij zich niet af wat voor soort man hij is. ${ }^{33}$ Ook met Laurens speelt Gerard zelfbewust een verleidende rol, en in die zin is zijn optreden net zo'n spel als met Christine. Gerard voorziet zijn handelingen ook bij Laurens van meta-gedachten: 'Nu moest hij [= Laurens] nog horen dat hij zelf, en niet alleen zijn kleding "beeldschoon" was. Enfin, dat kon wachten: niet te hard van stapel' (112). ${ }^{34}$

Gerards performance van heteroseksualiteit in De vierde man brengt de notie van een 'natuurlijke' mannelijkheid aan het wankelen: precies het omgekeerde van wat Butler beschrijft. Die omkering is alleen mogelijk als Gerard niet vanuit een heteronormatief standpunt denkt, waarbij mannelijkheid in relatie tot of afhankelijk van heteroseksualiteit wordt gedefinieerd. Gerard denkt (radicaal) vanuit een homoseksueel standpunt: voor hem is homoseksualiteit zo'n vanzelfsprekend uitgangspunt dat dat fungeert als normatieve praktijk, en pas bij afwijkingen (heterogedrag) gaan gendercategorieën schuiven. In een homoseksuele context is mannelijkheid voor hem geen enkel probleem. ${ }^{35}$ Ondermijnt Gerard hier de heteronormatieve matrix? Ja en nee. Behalve de parodie op heteroseksualiteit is er ook nog iets anders aan de hand.

\footnotetext{
${ }^{33}$ Laurens' gender is wel ambigu. Als Gerard hem bij het station ziet staan vraagt hij zich af of het een meisje in een broek is, of een jongen. Laurens gebruikt parfum (Gerard noemt hem dan ook een 'parfumnicht'), heeft 'meisjesachtig kleine' oren (111), een 'iets te hoge [...] stem' (111), maar is bij nader inzien 'nu definitief een jongen' (111). Binnen de homoseksuele context zijn dus duidelijke gegenderde posities ('mannen' en 'nichten'), zonder dat dat bij Gerard voor verwarring zorgt. Hij is min of meer vanzelfsprekend het (stoere) mannetje, terwijl Laurens als stereotiep 'vrouwelijk' wordt neergezet: 'Als je zulk een jongen had, dan had je geen meisje meer no$\operatorname{dig} . . .[\ldots]$ En in huis ongetwijfeld de hele dag poetsen en afstoffen, wasje doen, en "gewoon zalig" koken' (117).

${ }^{34}$ In het contact met Laurens is klassenverschil inzet van Gerards rollenspel: hij wil niet zozeer een man spelen als wel een gewone man, hij wil daarom geen 'boekentaal' spreken: 'Ik besefte dat ik zo banaal en onoorspronkelijk mogelijk moest optreden, wilde ik hem op zijn gemak stellen' (113). Hij beperkt daarom even later ook zijn 'revisme' (zijn seksuele fantasieën), omdat hij bang is dat dat Laurens' voorstellingsvermogen te boven zal gaan.

${ }^{35}$ Ik laat de vraag hoe opposities van de (hetero)norm precies gedacht moeten worden - bestaat er zoiets als buiten de norm? - hier rusten; Butler gaat daar nader op in 'Gender Regulations' (Butler 2004, vooral p. 50-52).
} 
Gerards optreden met Christine kan namelijk óók als een parodie van gender worden gelezen: hij is geen man, hij speelt een man. Op het eerste gezicht lijkt dat contra-intuïtief - hoezo zou Gerard geen man zijn? -, maar in zijn eigen opvatting is hij dat inderdaad niet. Gerard definieert een man namelijk meermalen als het tegenovergestelde van een flikker, helemaal conform de heteronormatieve opvatting van gender waarbij heteroseksualiteit een bevestiging vormt van 'echte' mannelijkheid. Als hij met Christine in bed ligt denkt hij bijvoorbeeld: 'Jammer [...] want je bent echt wel een lieve meid. Jij denkt dat je een man mee naar huis hebt genomen, maar hij is gewoon een flikker: een kat in de zak' (31). ${ }^{36}$ Later, als Christine hem heeft verteld dat hij in het kleine zijkamertje zal moeten slapen als Herman thuiskomt, stelt Gerard zich voor hoe hij Hermans hoofd middendoor zal klieven met een bijl, in plaats van te moeten luisteren naar hoe Herman het met Christine doet: 'flikker of niet, maar daarom kon je toch nog wel een man zijn?...' (100). Even verderop slaan Gerards gedachten over Laurens onmiddellijk op hemzelf terug, wat onmiskenbaar ironisch werkt: 'waarom waren niet alle flikkers zoals hij [Laurens], in plaats van almaar de man te willen spelen?. .' (122). Door zijn verhouding met Christine komt niet zozeer de vraag ' wat ben ik voor soort man?' bij Gerard op, als wel 'Ben ik (dan toch) een man?' - in plaats van een flikker. Dat vraagt hij zich af omdat hij herhaaldelijk seksueel opgewonden raakt, zoals hij tot zijn verrassing constateert: 'ik [voelde] mijn roede zich warempel [...] verheffen' (30).

Gerards parodie wordt mede gemotiveerd door een - weliswaar ambivalent - verlangen om normaal (lees hetero) te zijn, om 'de man te willen spelen'. Zijn positie is ongrijpbaar, ambivalent, zowel ondermijnend als bevestigend. Enerzijds verbindt Gerard gender en seksualiteit op een (hetero)normatieve manier, door over zichzelf te denken dat hij geen man, maar 'gewoon een flikker' is. Ook de manier waarop hij mannelijkheid en vrouwelijkheid definieert (als complementaire grootheden) is stereotiep. Anderzijds ondermijnt hij de notie van natuurlijkheid en authenticiteit juist doordat zijn mannelijkheid niet problematisch is in een homoseksuele context en doordat zijn parodie als hetero zo'n succes is. Hij weet Christine seksueel te bevredigen, en ervaart zelf bovendien seksuele opwinding. Het gaat zelfs nog verder, want Gerard denkt dat hij waarschijnlijk een betere man is voor Christine dan Herman, terwijl die al bij de eerste aanblik Gerards ideale man is, en een prototypische mannelijkheid vertegenwoordigt (onverzadigbaar, sterk, woest aantrekkelijk, etcetera).

\footnotetext{
${ }^{36}$ Datzelfde, 'een kat in de zak', denkt Gerard in Oud en eenzaam over Jacky, de homoseksuele vriend van Jane.
} 
De volgende vraag is hoe die parodieën, zoals ik ze zojuist geanalyseerd heb, verband houden met het gotieke in deze roman. Ik heb Christine aangewezen als de belangrijkste bron van gotieke spanning in De vierde man. Maar waarom zou de homoseksuele Gerard eigenlijk vatbaar zijn voor Christines (veronderstelde) dodelijke kracht? Hij speelt toch maar een spelletje, waar hij op ieder moment mee op kan houden? Op die vraag zijn denk ik twee antwoorden mogelijk. Het eerste antwoord luidt dat Gerard zo in het spel met Christine opgaat dat hij wel degelijk zichzelf dreigt te verliezen. Het tweede antwoord is dat Gerard zo verlangt naar het noodlot (fate) dat hij niets liever wil dan geloven dat Christine een fatale vrouw is. Het gotieke manifesteert zich op het moment dat het onderscheid tussen spel en werkelijkheid begint te vervagen, als Gerard zelf niet meer lijkt te weten wat spel is en wat echt is.

\section{ECHT EN ONECHT: HERMAN}

De affaire met Christine is een ambivalent spel. Dat spel roept bij Gerard tegenstrijdige gevoelens op, maar naarmate de tijd vordert krijgen gevoelens van onechtheid en teleurstelling de overhand. Dat blijkt bijvoorbeeld uit zijn veranderende perceptie van Christines huis. In eerste instantie is Gerard daarvan onder de indruk: 'we stopten bij een groot, alleenstaand huis in een vermoedelijk nog deftige straat van $19^{\mathrm{e}}$ eeuwse welstand' (24). Bij zijn tweede bezoek vindt hij het niet meer zo imposant en deftig:

$[\mathrm{H}]$ et grote woonhuis en de beide winkelpanden waren lang niet meer zo kolossaal als toen. Wat een groots, tragies avontuur met een rijke jonge vrouw had schijnen in te leiden, duidde bij nadere beschouwing veeleer op een grenzeloze verveling in een oninteressante buitenwijk. (72)

En tijdens het weekend dat hij op het huis past, doet het aan als 'een sombere grot' (105). In Christines huis zijn voelt aan als een 'aanraking met het onwerkelijke, en met de leegte' (66). Het gevolg is dat hij gaat twijfelen aan zijn en haar bestaan: 'afgezien van de oervraag, of $i k$ wel bestond - bestond zij wel echt?' (66). Ook zijn affaire met Christine gaat over van belofte in twijfel: 'Bestond er werkelijk "iets" tussen ons? Als het aan Christine lag, kennelijk wel...' (72). Uiteindelijk weet Gerard zeker dat er tussen hen niets echts is: 'Ik vroeg mij af, waarom in mijn leven alles zo gekunsteld en verzonnen aandeed. Een liefdesromance, tragies of niet, kon je het niet noemen, bijvoorbeeld.' (102). Horner en Zlosnik schrijven: 'In comic Gothic [...] the façade of the normal is 
a place of humour as well as horror' (Horner \& Zlosnik 2005, 144). Dat geldt ook voor De vierde man. Vooral het feit dat normaliteit een façade is, is funest. De komische gothic dient om de onechtheid van de normaliteit vorm te geven. De uitholling van het romantische, heteroseksuele plot in De vierde man gebeurt met komische gotieke middelen.

Gerards gevoelens van gekunsteldheid vormen een groot contrast met wat hij ervaart als hij Herman voor het eerst ziet, op een foto die hij vindt als hij in Christines paperassen snuffelt. Gerard vraagt zich nog even af 'Bestond dit?' maar weet dan, terwijl de foto 'in zijn hart' wordt 'afgedrukt', zeker: 'ik was niet gek...Er bestonden dingen...(62). Het is 'alsof de foto [...] altijd bestaan had, net als de jongen zelf (62). Herman is echt, dat lijdt geen twijfel, en Gerards gevoel voor hem ook: deze jongen is zijn leven en zijn lot.

Een cruciale scène in de roman is als Gerard doet alsof hij helderziende is en een séance opvoert voor Christine, waarbij hij de foto van Herman beschrijft (dezelfde die hij al stiekem heeft bekeken). Ook in deze rol weet Gerard Christine te overtuigen: 'neen, ze had niets, hoegenaamd niets in de gaten' (78). Terwijl hij doet alsof hij de naam van de jongen 'oproept', ervaart hij dat iets bezit van hem neemt dat hij zelf niet heeft opgeroepen. Het is een van de schaarse momenten in De vierde man dat Gerard naar eigen zeggen iets 'echts' ervaart, en bovendien iets wat hij niet in de hand heeft:

$[\mathrm{O}]$ peens werd het mij onbehaaglijk te moede...: er gebeurde iets dat ik niet speelde, maar dat echt was...Ik duizelde... Dwars door het beeld van de foto heen, die in een okeren, beige waas oploste, werd de gestalte van de jongen nu niet als een stilstaand herinneringsbeeld, maar lijfelijk zichtbaar, hier in de kamer, als een fantoom: en hij bewoog zijn lippen, onhoorbaar...Grote God! Nooit had ik dat opgeroepen, nooit...(79)

Gerard ziet Herman op de rand van een kade staan, met een oog dichtgeknepen. Hij heeft het gevoel dat hij gevaarlijk spel speelt, en dat Herman iets 'onzegbaars verschrikkelijks' van hem wil. De ervaring doet hem twijfelen aan zijn eigen nuchterheid: 'Zoude zoiets dan toch bestaan: mensen die voor de sport iets of iemand opriepen, maar het opgeroepene nam bezit van hèn. .? Welneen...Ja, spookverhalen bij de haard, griezelfilms, verder niks...En toch...' (80). Even later krijgt Gerard opnieuw een verschijning, als hij de foto van Herman mag vasthouden: 'Uit de foto steeg, wederom ongevraagd maar onstuitbaar, dat andere, nergens bij aansluitende en onverklaarbare beeld op, onheilspellend en bijna dreigend' (93). 
De gotieke verschijning van Herman, een verschijning met een bovennatuurlijke glans wordt door Gerard als het meest echt en authentiek ervaren. Die ervaring laat zich vatten in termen van bezit: Herman neemt bezit van Gerard, Gerard raakt bezeten van Herman - hij noemt hem al snel 'mijn lot, mijn leven' (95). Herman wordt het object waarop Gerard zijn verlangen naar een 'tragiese' romantische liefde kan richten. Temidden van de kunstmatigheid van Gerards rollenspel en de onwerkelijkheid in Christines huis is Herman het baken van echtheid. Onderdeel van die echtheid - in Gerards visie - is Hermans 'ouderwetse' mannelijkheid: hij heeft een 'stevig' handschrift, kan 'woest' en 'wreed' zijn, hij is 'een harde werker met een bloeiende eigen zaak' (89) en als hij gedronken heeft kan hij wel eens 'moeilijk' zijn. Herman wordt beschreven in termen van 'een ontembaar, onstuimig dier' (90).

Als Gerard hoort dat er iets niet goed is in de relatie tussen Christine en Herman fantaseert hij even over de mogelijkheid dat Herman misschien ook homoseksueel is: 'zoude hij, onze Herman, "mijn" Herman...misschien een "kat in de zak" zijn, en nog wel precies eenzelfde "kat" in precies eenzelfde "zak" als ik...?' (89). Dan zouden ze inderdaad voor elkaar bestemd zijn, denkt Gerard. Het probleem tussen Herman en Christine ligt echter niet aan Hermans mogelijke homoseksualiteit, integendeel. Herman komt te snel klaar en valt vervolgens onmiddellijk in slaap. Christine komt dus niet aan haar trekken in bed. Bovendien is Herman weinig vindingrijk, en zelfs een beetje preuts, zo verneemt Gerard van Christine als hij naar de problemen informeert.

Het feit dat Christine en Gerard dit als een probleem kunnen bespreken is een typisch product van de seksuele revolutie van eind jaren zestig, begin jaren zeventig in Nederland. Goed beschouwd vormt dit een anachronisme in de roman. Gerards affaire met Christine vond ergens in de jaren zestig plaats; de enige tijdsaanduiding is: 'Het was eind Mei 196*' (9), maar historische details ontbreken. ${ }^{37}$

Het gesprek tussen Gerard en Christine wijst op veranderde opvattingen over wat goede seks (ook voor vrouwen) is. Het valt vrij precies te dateren wanneer dat onderwerp in Nederland bespreekbaar werd gemaakt. Lag begin jaren zestig de nadruk nog op seksuele problemen, vanaf 1968 verscheen een stroom

\footnotetext{
${ }^{37}$ Aannemende dat Gerard gebaseerd is op Reve, valt de roman nog iets preciezer te situeren, aan de hand van Gerards leeftijd. Gerard zegt: 'Ik stond op de valreep van veertig te worden' (17). Reve werd 14 december 1923 geboren, dus zou de roman zich uiterlijk in 1963 afspelen. Er wordt in de roman eenmaal een contrast gememoreerd tussen (vertel)heden en verleden: de stadswijk waarin Christines huis destijds stond is verdwenen op het moment dat Gerard zijn verhaal aan Ronald vertelt; die heeft plaatsgemaakt voor een "'gezellig", modern, overdekt, "eigentijds" winkelcentrum' (9).
} 
aan brochures en boekjes waarin het seksuele plezier van vrouwen aan de orde werd gesteld. ${ }^{38}$ Die seksuele revolutie is kennelijk aan Herman voorbijgegaan; Christine en Gerard daarentegen betuigen zich geëmancipeerde seksuele subjecten - Gerard weliswaar achter 'een masker van hulpvaardigheid' (91) - die dankzij de seksuele revolutie hebben geleerd dat vrouwen ook seksuele verlangens hebben, dat een man niet alleen zijn eigen lust dient te bevredigen in bed, en die dat bovendien met elkaar kunnen bespreken.

Gerard biedt aan met Herman te praten, om zo te helpen Christines probleem op te lossen - een uitgelezen kans om met Herman in contact te komen. Opnieuw neemt het verhaal een ironische wending: de homoseksueel Gerard, de acterende one-night-stand van Christine, vermoedt dat hijzelf eigenlijk een betere man voor haar kan zijn dan haar echte vriend die het prototype van mannelijkheid belichaamt, Herman. Gerard kan Christine namelijk beter seksuele bevrediging bezorgen, juist omdat hij niet zo opgewonden door haar raakt en het liefdesspel zo langer kan rekken: 'Ik overwoog dat, net als in de vroeger eeuwen door de dames zo gezochte eunuchen, een man van de herenliefde...wat de feitelijke paringsdaad betrof nog niet eens zo onbruikbaar was' (91). Gerard vergelijkt zichzelf ('een man van de herenliefde') hier met een gecastreerde man ('eunuchen'). ${ }^{39}$ Met andere woorden, ook niet-mannen (flikkers) of ontmanden (eunuchs) kunnen vrouwen seksuele bevredigen, misschien wel beter dan 'echte' mannen. Wat Gerard zelf betreft pleit het juist voor Herman dat die daar niet vatbaar voor is ('een woeste man, is dat niet opwindend?' vraagt hij aan Christine): dat bevestigt alleen maar Hermans status als Echte Man.

Dit gesprek over seks tussen Gerard en Christine krijgt wederom een ironische echo in de ontmoeting tussen Gerard en Laurens. Gerard betoont zich een hoffelijke, seksueel geëmancipeerde man in de seks met Laurens. Nadat hijzelf is klaargekomen biedt hij Laurens zijn diensten aan: 'Uit medemenselijkheid wil-

\footnotetext{
${ }^{38}$ Publicaties die de plezierige kanten van seks benadrukken, mede of specifiek op vrouwen gericht: Ellis, Plezier in seks (1967), Westerman Holstijn, Seksualiteit van de volwassen vrouw (1968), Kaare, Erotiek (1969), Ejlersen, Orgasme bij de vrouw (1972); De kunst van het vrijen (1977); Kerr, Vrouwen en sex: een handleiding voor vrouwen die plezierige en volwaardige sexuele relaties willen hebben (1978). In 1978 verschijnt ook nog de NVSH-brochure Klaar is Kees, maar hoe zit het nou met Marie? Ter vergelijking: in een brochure uit 1960 worden nog vooral de problemen benadrukt: zie Swelheim-de Boer, Seksuele moeil kheden van de vrouw: naar een bewerking van 'Sex difficulties in the wives'. Zie ook Röling (1994).

${ }^{39}$ Garlick (2003) benadrukt nog eens dat heteroseksualiteit de belangrijkste pijler onder mannelijkheid is: 'heterosexuality produces a hegemonic notion of masculinity' (Garlick 2003, 159). Tegelijkertijd is die (hetero)seksuele daad 'a site of contestation for masculine identity, an encounter with the "other" that challenges at the same time as it affirms and stabilizes the dominant category' (Garlick 2003, 158-159).
} 
de ik daarna nog even zijn jongensdeel beroeren, maar dat behoefde niet, daar gaf hij niks om...Alleen van achteren telde bij hem' (120). Met terugwerkende kracht wordt het moderne (hetero)seksuele ideaal van seksuele gelijkberechtiging, in de vorm van wederzijdse bevrediging, weer onderuit gehaald.

Reve speelt hier met opvattingen (deels clichés) over hetero- en homoseksualiteit, mannelijkheid en vrouwelijkheid, die eind jaren zestig inzet werden van een sociaal-culturele strijd. ${ }^{40}$ Hoe is dat spel verweven met ambivalenties over traditie en moderniteit? Gerard probeert een 'echte', hoffelijke man te zijn ten opzichte van Christine, zoals hij dat vanzelfsprekend is ten opzichte van Laurens. Zijn optreden is overtuigend, maar Christine voldoet niet aan een traditioneel beeld van welgestelde dame uit romantische sprookjes. Ze beantwoordt niet aan het traditionele plaatje: ze is economisch onafhankelijk en seksueel autonoom.

Terwijl Gerard zijn best doet deel uit te maken van de façade, door een man te spelen, blijkt de vraag wat een echte man is niet meer zo simpel te beantwoorden. Traditionele mannelijkheid volstaat in het contact met Laurens, maar niet met een moderne vrouw als Christine, dan blijkt de 'fragility of traditional manhood'. ${ }^{41}$ Christines drie echtgenoten zijn al dood en Herman, dat toonbeeld van mannelijkheid, wordt ernstig verminkt - hij verliest een oog 'bij de enige bekende botsing in West-Europa tussen een auto en een schip' (141-142). ${ }^{42}$

In De vierde man dient het gotieke om ambivalenties rond definities van mannelijkheid vorm te geven. Herman verschijnt als fantoom van traditionele, authentieke mannelijkheid; Christine is de gotieke femme fatale, de angstaanjagende moderne vrouw. Nieuwe verhoudingen tussen mannen en vrouwen die het gevolg zijn van de toegenomen autonomie van vrouwen - seksueel en ecomisch - leidt tot onzekerheid in heteroseksuele verhoudingen. Zelfs Gerard blijkt vatbaar voor die onzekerheden: zijn parodie als hetero dreigt met hem op de loop te gaan. Authenticiteit lijkt moeilijk te bereiken, behalve wanneer Gerard denkt vanuit een radicaal homoseksueel perspectief. In de rest van dit hoofdstuk bespreek ik eerst de consequenties van dat perspectief voor de theorie van Eve Sedgwick, en vervolgens voor Reves schrijverschap.

\footnotetext{
${ }^{40}$ Zie ook Kennedy (1995), p. 141-143.

${ }^{41}$ Die term is van Cyndy Hendershot (2003), die analyseerde hoe traditionele heteroseksuele mannelijkheid in de gothic novel herhaaldelijk bevraagd wordt.

${ }^{42}$ Dat is een verminking die aan castratie doet denken (zoals Oedipus' blind worden door Freud als symbolische castratie geïnterpreteerd is, en net zoals in Freuds analyse van Der Sandmann in Das Unheimliche, waarin hij ook de parallel tussen verblinding en castratie trekt; denk ook aan Rochester, wiens blindheid is gelezen als voorwaarde om een huwelijk met Jane Eyre mogelijk te maken (zie Buikema 1997). Zie ook hoofdstuk 5.
} 
In De vierde man ontbreekt een expliciet religieuze dimensie, zeker in vergelijking met ander werk van Reve. ${ }^{43} \mathrm{Op}$ de momenten dat Gerard contact heeft met 'het hogere' krijgt dat vooral een gotieke lading, denk aan de séance met Hermans foto. ${ }^{44}$ De verwijzingen naar religie zijn schaars, al zijn er wel enkele. Als Gerard zich realiseert dat hij Christine nooit werkelijk zal begeren denkt hij: 'Ik gevoelde dit als een smartelijk onrecht dat ik, zonder dat ik zulks wilde of goedkeurde, haar in gehoorzaamheid aan een duister lot moest aandoen. Het lot, jawel; of, met een ander woord: God. Was het onrecht uit God?' (36). Wanneer Gerard Christine ziet als een middel om Herman te bereiken, gebruikt hij de frase 'door háár tot hèm' (92), en vertaalt die dan in een oude katholieke uitdrukking: 'door Maria tot Jesus' [sic] (95).. ${ }^{45}$ Door het gebruik van

\footnotetext{
${ }^{43}$ Volgens Moerbeek (2004) en Ligtenberg \& Van Stipriaan (1985) valt dat af te leiden uit de afwezigheid van rode wijn. In Reves boeken (en in zijn leven, kan eraan toegevoegd worden) wordt meestal rode wijn gedronken. Ligtenberg \& Van Stipriaan stellen dat 'in zijn werk [...] rode wijn noodzakelijk [is] [...] voor het beleven van de religie' $(1985,24)$. In De vierde man drinkt Gerard echter de voor Reve atypische tonic-met-een-tic, en whisky ('wiskie'); Christine drinkt voornamelijk sherry, een typisch (huis)vrouwendrankje.

${ }^{44}$ Het gotieke en het religieuze sluiten elkaar overigens niet uit; beide putten uit dezelfde bron die aan te duiden val;t als het numineuze. Die term is van Rudolf Otto (1917) en duidt het mysterium tremendum et fascinans aan, het 'volledig andere' dat de basis vormt van de religieuze ervaring. Gerard zegt dat hij zijn verhaal lang geheim gehouden heeft omdat 'er iets geheimzinnigs - een even zinvol als angstaanjagend numinosum - in het gebeuren' (8) is. Polak schreef over het 'numen' in het vroege werk van Reve (tot 1968): 'Het numen, de onnoembare macht [...] wordt door rituele marteling of reiniging bezworen' (Polak 1990, 35). Varma (1966) beschouwt de gothic als een 'quest for the numinous' (Varma 1966, 211). Horner en Zlosnik (2004) noemen het moderne 'loss of transcendence' als een van de belangrijkste motivaties voor de gotieke roman. ${ }^{45}$ De frase 'Door Maria tot Jezus' had Reve al eens gebruikt om een potentiële driehoeksrelatie te beschrijven. In een brief aan Simon Carmiggelt (gedateerd 13 oktober 1972) schrijft hij: 'Ik ben nogal verliefd, intussen, op een Blauwe Jongen van ca. 25, die getrouwd is met een jonge vrouw. Die vrouw is heel knap en sierlijk van bouw en sportief van koerakter [sic], maar boeit mij lichamelijk weinig of niets, terwijl ik háár nu weder wel degelijk boei. "Door Maria tot Jezus", zul je natuurlijk allang denken, oude hitsige kapotgedronken doorroker van een sater die je bent, maar ik zie er tegen op.' (geciteerd in Derks 2002, 119). Opvallend detail is dat Ronald, Gerards toehoorder in De vierde man ook Indisch is ('blauwe' is een pejoratieve term voor Indisch). In Moeder en zoon (1980), Reves autobiografische relaas over zijn toetreding tot de rooms-katholieke kerk, komt de uitdrukking opnieuw voor als hij beschrijft hoe hij in de gevel van een kapel in Heiloo de woorden 'DOOR MARIA TOT JESUS' gemetseld ziet staan (Reve 2001, 653). In een brief aan Gerard S. schrijft Reve: 'Een heel begeerlijke jonge weduwe in de Zeeuwse stad V. heeft daarnet wel twintig minuten lang opgebeld. Ik heb er wel zin in, maar zie tegen de rompslomp op. Ze heeft het uitgemaakt met een vriend die op een zeehond heet te lijken, en die kort daarop onder invloed van 8 libriumtabletten en 1 liter wiskey [sic] twee autoos total loss en zichzelf één
} 
dit katholieke gezegde krijgen Christine en Herman in De vierde man een religieuze dimensie. Tegelijkertijd wordt Gerards relatie tot Maria en Jezus in seksuele termen gevat.

'Door haar tot hem' is niet alleen een rake manier om De vierde man te karakteriseren, het lijkt ook de kortst mogelijke samenvatting van Eve Kosofsky Sedgwicks these dat homosociale banden worden aangeknoopt of verstevigd via (rivaliteit over) vrouwen (Sedgwick 1985). ${ }^{46}$ De rivaliteit tussen twee mannen die om dezelfde vrouw strijden creëert een minstens even sterke band tussen hen, als tussen de vrouw en de minnaar. Sedgwick doelt (juist) niet op seksuele banden tussen mannen, maar op de hechte sociale banden tussen mannen.

Gerard drijft Sedgwicks driehoeksmodel tot een pijnlijk hilarisch uiterste. $\mathrm{Hij}$ is een homoseksueel die even lonkt naar een heteroseksueel bestaan, maar uiteindelijk meer naar de man in de driehoek verlangt - en wel degelijk seksueel. Gerards verlangen naar seksuele eenwording met Herman vindt plaats heel plastisch - via de seks met Christine, of zoals Gerard het verwoordt: 'En zoals zij hem ging toebehoren, zo zoude hij mij eens toebehoren, door háár...Ik schoof, duizelend van verrukking, mijn deel in haar liefdesgrot naar binnen, die zíjn angel, zíjn liefdesdolk ontvangen en gediend had...Ja door haar en in haar, tot hèm ..."Door Maria tot Jesus ..." dacht ik vol vervoering.' (95).

Potentiële rivaliteit tussen Gerard en Herman met Christine als object maakt plaats voor rivaliteit tussen Gerard en Christine: beiden verlangen naar dezelfde man. Er is alleen sprake van rivaliteit tussen Herman en Gerard wanneer Gerard door Christine naar het zijkamertje wordt verbannen, omdat Herman komt. Dat kunnen we beschouwen als de burgerlijke uitzondering die de

oog minder heeft gereden. Het leven is een strijd.' (9 maart 1968, in Reve 1985, p 154). N.B. Gerard S. is niet Gerard Soeteman, maar heet eigenlijk Jan S. Zie Bert Boelaars (2002, 12 e.v.) (met dank aan Nop Maas)). In 1996 spoorde een journalist van HP/De Tijd een Vlissingse kapster op met de naam Christine Inderwisch (Verstraten 1996). Zij bevestigde dat ze Gerard Reve had ontmoet en met hem had gecorrespondeerd, maar wilde niet onthullen of ze een verhouding met hem had gehad. Deze voorbeelden laten zien hoe Reve zijn eigen autobiografische bronnen in een fantastische mix hergebruikt, en omvormt naar de conventies van de gotieke roman. Recensenten beschouwden de roman juist als een overduidelijk verzonnen verhaal, en Gerard Soeteman, de scenarioschrijver van De vierde man, riposteerde op kritiek dat acteur Jeroen Krabbé niet overtuigend was als Gerard Reve: 'het gegeven van De Vierde Man is duidelijk zo weinig autobiografisch dat de link met de echte Reve niet voor de hand lag' (geciteerd in Beekman 1986, 11). In de verantwoording bij het scenario van De vierde man schrijft Soeteman iets heel anders, namelijk dat het personage Gerard wel degelijk op Reve gebaseerd is: 'Omdat de hoofdpersoon van “De Vierde Man” geënt is op Reve is Gerard bi-sexueel' (Soeteman 1991, 10). Gerard krijgt het laatste woord over het waarheidsgehalte van zijn verhaal: 'het is $[\ldots]$ als elk waar verhaal, een beetje onwaarschijnlijk en ongeloofwaardig.' (8)

${ }^{46}$ Zie ook hoofdstuk 4. 
(radicale) regel bevestigt. De homo-geëmancipeerde vertaling van Sedgwicks driehoek, een onverhulde verschuiving van het liefdesobject - van de vrouw naar de man - is mogelijk geworden.$^{47}$ In de erotische driehoek die Reve schetst zijn alle zijden expliciet seksueel geworden, waardoor het object kan verschuiven, en ook de rivaliteit. De consequentie voor het gotieke mechanisme dat Sedgwick ontwaarde is dat de relatie tussen de mannen niet langer per definitie paranoïde wordt - integendeel. Gerard wil niets liever dan door Herman bezeten worden. Zijn paranoia betreft nu Christine - als zij eens fataal voor hem blijkt te zijn? De conclusie is dat zij niet langer als passief doorgeefluik in de driehoek past nu ze zo autonoom is. De paranoia die Gerard voelt wordt veroorzaakt doordat zij zijn rivaal is ten opzichte van Herman, al weet zij dat zelf niet. De paranoia wordt in ieder geval niet gevoed door angst voor homoseksualiteit - die angst is niet aan de orde -, maar door angst voor een vrouw.

\section{SEKSUALITEIT EN SCHRIJVERSCHAP}

In deze roman verliest iedereen uiteindelijk, al moeten we daar niet al te zwaar aan tillen; daarvoor blijft de toon te luchtig. Herman verongelukt, Christine verliest haar geliefde, en uiteindelijk verliest ook Gerard: niet Herman (die had hij nooit), of Christine (die wilde hij niet echt), maar Ronald. Er staat voor Gerard bovendien nog meer op het spel dan een geliefde: zijn schrijverschap. De vierde man bevat in de raamvertelling een reflexieve laag: verteller Gerard becommentarieert zijn eigen verhaalkunst. Door dit reflexieve niveau wordt het ingebedde verhaal over Gerard en Christine inzet van een beschouwing over Gerards schrijverschap en zijn vermogen om een verhaal te vertellen. ${ }^{48}$

In Reves werk is schrijverschap hecht verbonden met seksualiteit. De belofte van seks, of de daad zelf, brengen de verbeelding van de protagonist op gang -

\footnotetext{
${ }^{47}$ Met behulp van De vierde man kan het (tamelijk starre) structuralistische model waarop Sedgwick zich baseert hergedefinieerd worden. Butler betwijfelt in 2002 of Sedgwick het nu nog zo structuralistisch zou formuleren: 'It is [...] 1985 when Sedgwick publishes this text, and it was no doubt much easier then to posit true objects of desire. [...] I cannot imagine that she [Sedgwick] would necessarily accept a logic of noncontradiction for desire, in which one either desires a man or a woman, but not both, and not both at the same time' (Butler 2002, 110). Reve had die tegenstrijdige logica dus al in 1981 onder de knie.

${ }^{48}$ Voor beschouwingen over metafictie zie bijv. Currie (1995) en Waugh (1984). Hanneke Mulder (1992) prefereert de term reflexiviteit boven metafictie, omdat zij die niet opvat als een teksteigenschap, maar als een wisselwerking tussen tekst en lezer. Zowel zelfverwijzingen in literaire teksten en (literatuurkritisch) zelfbewustzijn van de lezer zijn noodzakelijk om die reflexiviteit te realiseren. Zie Mulder (1992), met name p. 6-17.
} 
vaak een ik-persoon of een personage met de naam Gerard - en vormt de grondstof voor Reves boeken, zo niet de voorwaarde ervoor. De taal der liefde (1972) en Lieve jongens (1973) bestaan grotendeels uit dit soort zogenoemde Sexualmärchen, maar ook Oud en Eenzaam (1978) en Moeder en Zoon (1980) bevatten grote delen met bedverhalen die aan de geliefde verteld worden. Volgens Will Derks (2002) zijn de Sexualmärchen bedoeld om zowel verteller als toehoorder seksueel op te winden. De eenwording die door de schrijver/verteller verlangd wordt is echter evenzeer van seksuele als van mystieke aard, wanneer de seksuele daad transformeert tot schrijfdaad.

In De vierde man zijn er breuken in de elders zo vanzelfsprekende verbinding tussen opwinding en fantasie, en tussen seks en schrijven. Gerards verbeelding wordt in eerste instantie wel geprikkeld door de exotische geur van Christines parfum: 'de mij onbekende bloemengeur joeg mijn verbeelding [...] terdege op, en ik gevoelde in mijn kruis dat ik wel degelijk een man was (25). Ook de fantasie die volgt over het 'tuchtigen' van Christine heeft de voor Reve gebruikelijke seksuele ondertoon en SM-dynamiek. ${ }^{49}$ Maar als puntje bij paaltje komt, als hij daadwerkelijk met Christine in bed ligt, is Gerards fantasie opvallend afwezig. Het eerste seksuele contact tussen hen blijft - onreviaans - vrijwel onbeschreven; meer dan een alinea wordt er niet aan gewijd. Gerard wordt pas echt opgewonden na afloop, als hij zich voorstelt dat zij een heks is die gestraft moet worden, maar hij gebruikt die fantasie niet om haar op te winden. Als hij een week later opnieuw met haar naar bed gaat fantaseert hij even over Herman, maar opnieuw deelt hij die fantasie niet met Christine.

Seksualiteit en schrijverschap vormen in De vierde man dus geen organisch geheel: Gerard prikkelt Christine niet met zijn fantasieën en het schrijven volgt niet vanzelfsprekend uit de seks - alleen al in tijd en plaats zijn de twee activiteiten gescheiden. Als contrast kan de scène met Laurens dienen: daarin komt Gerards 'revistiese' fantasie wel goed op gang - inclusief de trio-fantasie, met zusjes en tweelingen en al -, en die deelt hij ook met Laurens, al durft hij niet alles aan Laurens te vertellen uit angst dat die hem niet zal begrijpen. ${ }^{50} \mathrm{Zijn}$

\footnotetext{
${ }^{49}$ Zie over wreedheid en seks bij Reve in een homoseksuele context Hekma $(1986,1990)$ en Hafkamp (1991), p. 22-23. Over revisme: Dijkhuis (1986). Dijkhuis betoogt ook dat de connectie die door critici vaak gelegd wordt tussen Reves figuur van de Meedogenloze Jongen en Praz' Belle Dame sans Merci te los is, omdat de laatste doelbewust haar prooi in het verderf stort, wat niet voor de Meedogenloze Jongen geldt.

${ }^{50}$ Gerard vertelt Laurens dat Christine en hij een tweeling zijn (en dat hij met haar zeer intiem is), en dat Herman hun beider geliefde is - zodat een driehoeksverhouding in alle richtingen ontstaat. Snapper wijst op de veelvuldige verdubbeling van personages bij Reve - een 'Ander met wie een nauwe verwantschap bestaat' (Snapper 1990, 179). Snapper leest dat als Reves verlangen naar zelfverwezenlijking en onsterfelijkheid. Vaak krijgt de geliefde het liefkozende woord 'broer-
} 
verbeelding werkt kortom alleen om de seksuele daad te verhevigen als er een homoseksueel (liefdes)object is (Herman of Laurens). ${ }^{51}$

Gerard houdt zichzelf voor dat Christines huis een uitgelezen plek zou zijn om te schrijven, maar hoewel hij gewapend is met potten inkt, een gros kroontjespennen en een heel pak papier, blijkt al snel dat schrijven niet lukt: 'Neen, hier geviel geen letter te schrijven.' (105) De fantasie over het schrijven in het huis van Christine staat los van de seks met haar.

Gerard vertelt zijn verhaal over zijn affaire met Christine vele jaren na dato aan zijn geliefde, Ronald. Het verhaal lijkt dezelfde inzet te hebben als bedverhalen in ander werk van Reve. Enerzijds dient het als materiaal voor het schrijven, anderzijds dient het om zijn band met zijn geliefde, in dit geval Ronald, te versterken. Zo stelt Gerard aan het begin van zijn verhaal tevreden vast dat hij Ronalds 'bezitsmatige nieuwsgierigheid' (8) heeft weten te wekken. Het verhaal over Christine werkt echter niet als een Sexualmärchen; er vindt in de roman geen seks plaats tussen Ronald en Gerard. Integendeel, in de raamvertelling valt te lezen dat hun relatie geen stand heeft gehouden:

Hij was lief, Ronald, hij was mooi, intelligent, gevoelig, zorgzaam, trouw, en ik had hèm moeten kiezen, jaren geleden, toen hij waarschijnlijk nog, als ik zijn hand gevraagd had, ja gezegd zoude hebben...Nu was het te laat: $M y$ dancing days are over...(140).52

Dat het niet goed afloopt tussen Gerard en Ronald valt ook af te leiden uit het feit dat Gerards verhaal over de affaire met Laurens niet als bindmiddel werkt. In Reves sadomasochistische bedverhalen is het een teken van ultieme liefde als de verteller aan zijn geliefde een jongen 'aanbiedt' om te martelen..$^{53}$ In De vierde man laat Gerard in denigrerende, racistische bewoordingen weten dat hij het

tje' mee. Snapper: 'Een broer is iemand die zoveel mogelijk op Reve lijkt, zonder zijn "anders"zijn volledig prijs te geven, waardoor er een incestueuze relatie ontstaat die zijn narcistische kern niet verliest.' (180) In dit geval krijgt Christine dus de eretitel 'zusje': 'We waren Zusje en Broertje geworden, Christine en ik' (94).

${ }^{51}$ Het contact met Christine heeft een vergelijkbare structuur als de scène met het personage Otto van D. in Moeder en zoon: niet het ideale liefdesobject, maar wel het middel om over dat ideaal te fantaseren. Gerard fantaseert in de scène met Otto uitgebreid over Matroos. Het verschil is dat hij die fantasie wel deelt met Otto, en een ander verschil is dat Otto duidelijk onderworpen is, Christine niet.

52 Overigens is Gerards gedachte dat hij Ronald had moeten kiezen een doorbreking van de chronologie, die erop wijst dat hij deze overpeinzing over Ronald nog weer later vertelt, en nu aan de lezer.

${ }^{53}$ Dit is wat Reve het 'revisme' noemt. 
juist problematisch zou vinden als Ronald Laurens zou 'plagen': 'nu weet ik dat jij, door die jaloerse aangeboren wreedheid van je die jouw ras nu eenmaal eigen is, dat jij die lieve blonde beeldschone blanke jongen [nl. Laurens] meteen zou gaan plagen' (144). Als Ronald echt zijn ideale geliefde was zou Gerard dat juist aanmoedigen. Gerard vernedert Ronald door een koloniaal vertoog in te zetten bij zijn pogingen hem aan zich te binden. Ronald is daar niet van gediend: 'Ik maakte hem razend door hem in gezelschap djongos te noemen, dat terwijl mijn diepste verlangen was, zíjn oppasser en zíjn hutbediende te zijn, al hield ik dat voor hem streng geheim: als je die katjangs een vinger gaf, dan beten ze meteen je arm af...' (140). Ronald ervaart de benaming 'djongos' (inlandse huisbediende) begrijpelijk als kwetsend. Ook in dit geval vat Gerard zijn relatie in termen van bezit, van een machtsstrijd, net als in het geval van Christine en Herman. Maar zijn diepste verlangen om bezeten te worden, overmeesterd te worden, kan hij niet uiten zonder verwijzingen naar koloniaal racisme, en het gevolg is dat hij Ronald verliest.

Ronald moet Gerard niet alleen bevestigen als geliefde, maar ook in zijn status van schrijver/verteller. De ironie is dat geen ander boek van Reve zozeer is onthaald als 'spannend verhaal', terwijl verteller Gerard meer dan sceptisch is over zijn eigen verhaalkunst. Hij vertelt zijn verhaal over Christine en Herman aan Ronald om te checken of hij een verhaal heeft - hij heeft destijds weliswaar niets kunnen schrijven, maar wellicht redt het vertellen van zijn belevenissen hem van de dood als schrijver. Ronald wordt door Gerard als ideale luisteraar voorgesteld: hij zou bij uitstek een echt verhaal op waarde kunnen schatten, omdat hij Indisch is: 'Jij als plopper, geboren en opgegroeid in Ons Indië, met de goena goena bijvoorbeeld, jij ziet dat verband natuurlijk meteen' (139). ${ }^{54}$ Ronalds Indisch-zijn maakt hem kennelijk ontvankelijk voor de gotieke verschijnselen in Gerards verhaal..$^{55}$ Maar de over-geëxpliciteerde nabespreking, waarin elk onderdeeltje nog eens wordt nagelopen en Ronald zegt dat hij het wel een verhaal vindt, heeft een ironisch effect: 'Nou....als je het goed vertelt, met alles er op en er aan...dan...dan zie je toch dat het allemaal met elkaar te maken heeft:...die droom...die sleutel...die doos...' (143). Ronald spelt alle verbanden nog eens uit en lijkt daardoor eerder onnozel dan ideaal.

Gerards twijfel over zijn verhaal zit hem in de terugkerende vraag of hij iets beleefd heeft wat een 'kosmies noodlot' was of toeval. Een 'echt' verhaal in Ge-

\footnotetext{
${ }^{54}$ Derks noemt dit citaat over Ronald 'even geestig als meedogenloos' (Derks 2002, 124). 'Plopper' is afgeleid van het Maleise pelopor, een beledigend woord voor een Indonesische vrijheidsstrijder. 'Goena goena' verwijst naar tovermiddelen.

${ }^{55}$ De connectie tussen het (post-)koloniale en gothic is onder andere geanalyseerd door Smith \& Hughes (2003).
} 
rards opvatting is een verhaal dat niet door toevalligheden, maar door het lot gestuurd wordt. De tegenstelling tussen het noodlot - waaraan je bent overgeleverd - en een toevallige samenloop van omstandigheden, die je naar je hand kunt zetten is bepalend. Met andere woorden, tussen controle over de situatie of eraan overgeleverd zijn - tussen bezitten of bezeten worden. Bezeten worden betekent overgeleverd zijn aan het lot, en dat levert een 'echte' ervaring, en een echt verhaal op. Gerard wil zich als schrijver/verteller overleveren aan het noodlot, maar in dit geval heeft hij twijfels over de authenticiteit van zijn verhaal:

Is het een verhaal?...Er zit een verhaal in, op een bepaalde manier, maar tegelijkertijd is het zo hol, zal ik maar zeggen... Het is net of het in het midden leeg is...Het heeft geen...body, bij wijze van spreken...In het midden gebeurt niks, eigenlijk... (145)

Het verhaal is hol, zo hol als de sleutel die Gerard in zijn droom aanzag voor een pistoolloop. Er is geen midden, hoezeer Ronald hem ook zegt dat het wel een verhaal is. Wat ontbreekt er?

\section{EEN VERHAAL MOET NIET TE VROEG KLAARKOMEN}

Gerards verlangen naar een betekenisvol verhaal en zijn probleem met het midden laten zich verrassend goed vatten in de terminologie van de psychoanalytisch geïnspireerde verhaaltheorie van Peter Brooks, die de sociale en psychologische functies van het narratieve plot onderzocht (Brooks 1992 [1984]). ${ }^{56}$ Brooks stelt dat mensen proberen de chaos van gebeurtenissen in de wereld te interpreteren via verhaal- en plotstructuren, waarmee een zinvol verband wordt aangebracht - eerst in een tekst, en vervolgens, met de tekst als model, in de werkelijkheid. Een voorbeeld bij uitstek van zo'n plotstructuur waar die zinvolle ordening van gebeurtenissen anwezig is, is de detective - het genre dat voortkomt uit en nauw verwant is aan gotieke fictie:

The urgency of narrative explanation in modern times is [...] well represented in that nineteenth century invention, the detective story, which claims that all action is motivated, causally enchained and eventually comprehensible as such to the perceptive observer. (Brooks 1992, 269)

\footnotetext{
${ }^{56}$ Voor een Nederlandse inleiding op het werk van Brooks zie Corporaal (2006).
} 
Gerard, die als personage probeert de raadsels rond Christine te duiden, probeert als verteller/schrijver betekenis te geven aan zijn belevenissen. Hij twijfelt of hij daar wel in geslaagd is, en laat daarom Ronald de keten van gebeurtenissen reconstrueren om te beoordelen of ze met elkaar in een zinvol verband staan. Plots zijn dynamisch, ze bewegen zich voort van een begin naar een einde, en dit vertoont volgens Brooks overeenkomsten met het inherent menselijke verlangen naar het einde (Freuds doodsdrift). Zo drijft het verlangen van de hoofdpersoon in een verhaal het plot naar zijn bevredigende einde. Maar het eind mag niet te snel komen; via verplichte omwegen in het midden moet de spanning worden opgebouwd:

[T] he intentionality of plot lies in its orientation toward the end even while the end must be achieved only through detour. [...] Crucial to the space of this play are the repetitions serving to bind the energy of the text in order to make its final discharge more effective. (Brooks 1992, 108)

Het is de kunst de climax van het verhaal precies lang genoeg uit te stellen, want een voortijdige ontlading (Brooks' term 'final discharge') is teleurstellend. Een oeverloos verhaal, zonder einde, is ook niet goed, maar minder acuut bedreigend. De parallel met het mannelijk orgasme is evident. ${ }^{57}$ Gerard kent die verhaalwetten maar al te goed. Hij vertelt zijn verhaal over de affaire met Christine aan Ronald - en doseert de spanning vakkundig. In eerste instantie houdt hij op te vertellen bij zijn vertrek 'halsoverkop' uit Christines huis: 'ik genoot ervan de klap op de vuurpijl nog even uit te stellen.' (139). Maar hij weet ook wanneer hij de afloop moet onthullen: 'Ik kon de spanning niet langer rekken en moest met de rest voor de dag komen' (141). 'De rest' is dat Gerard van Christine hoort hoe Herman zich te pletter heeft gereden en daarbij een oog is kwijtgeraakt. $^{58}$

Lezers voelen volgens Brooks' theorie een voortdurende spanning - een mengeling van opwinding en angst - voor een 'verkeerd' einde, een kortsluiting van het verhaal. Die kortsluiting kan bestaan uit allerlei bedreigingen voor de hoofdpersoon, maar neemt volgens Brooks vaak de vorm aan van de keuze voor een 'foute' vrouw. Ik citeer een lange passage waarin hij de risico's voor zo'n

\footnotetext{
${ }^{57}$ Diverse auteurs hebben de in het oog springende overeenkomsten tussen mannelijke seksualiteit en narrativiteit in Brooks' terminologie opgemerkt en hem daar om bekritiseerd. Zie Hirsch (1986), Winnett (1990) en Aydemir (2004).

${ }^{58}$ Het numineuze wordt aldus bezworen door verminking, zoals Polak (1990) beschreef voor het vroege werk van Reve, zie noot 44 .
} 
vroegtijdige ontlading opsomt, die in het geval van De vierde man zeer toepasselijk zijn:

It is characteristic of textual energy in narrative that it should always be on the verge of premature discharge, of short-circuit. The reader experiences the fear - and excitation - of the improper end, which is symmetrical to but far more immediate and present than - the fear of endlessness. The possibility of short-circuit can of course be represented in all manner of threats to the protagonist [...]; it most commonly takes the form of temptation to the mistaken erotic object choice, who may be of the "Belle Dame sans merci" variety, or may be the too-perfect and hence annihilatory bride. Throughout the Romantic tradition, it is perhaps most notably the image of incest (of the fraternal-sororal variety) which hovers as the sign of a passion interdicted because its fulfillment would be too perfect, a discharge indistinguishable from death, the very cessation of narrative movement. (Brooks 1992, 109)

Zoals eerder bleek is Gerard bezorgd over zijn verhaal omdat het geen midden heeft, het is hol van binnen. Met Brooks' verhaaltheorie in de hand is die twijfel wel begrijpelijk. Hij heeft precies het 'foute' liefdesobject gekozen, de Belle dame sans Merci (Christine). ${ }^{59}$ Dit romantisch-gotieke personage Christine zou volgens Brooks een risico vormen dat het verhaal te snel afgelopen is, omdat een fatale vrouw de mannelijke held (en daarmee een bevredigend verhaal) bedreigt met castratie/dood: zie de drie dode echtgenoten en de verminking van Herman. Maar Reve zet de Belle Dame sans Merci, die gewoonlijk het noodlot personifieert en daarom een risico is voor het verhaal, op twee manieren buitenspel. Ten eerste ís Gerard al een niet-man die zichzelf vergeleek met een eunuch, hij hoeft dus niet bang te zijn voor een al te snel einde (anders dan Herman die zijn significant discharge te snel loost). En ten tweede is niet Christine Gerards (nood)lot - met haar voelt alles 'gekunsteld en verzonnen' (102) - maar Herman. Wel is er een ander risico: een gebrek aan een goed middendeel - zijn verbeelding werkt niet met Christine.

Door de nauwe band tussen seks en verhalen vertellen in Reves werk vormt het een bijzondere illustratie van Brooks' theorie. Terwijl bij Brooks seksuele

\footnotetext{
${ }^{59}$ Daar komt nog eens bij dat Gerard Christine ook beschrijft in termen van zusje-broertje: hij denkt als een van de eerste dingen over Christine dat zij zijn zusje zou kunnen zijn ('[I]k [had] het bijvoorbeeld in het geheel niet erg [...] gevonden, als ze mijn zuster zoude zijn' (17), en later met Laurens fantaseert hij hardop dat Christine en hij een tweeling zijn. Het beeld van incest, dat Brooks als tweede mogelijke mislukking formuleert, zweeft dus ook tussen de regels.
} 
spanning een metafoor is voor narratieve spanning, gaat het bij Reve om de daadwerkelijke seksuele inhoud van het verhaal. In het romantische heteroseksuele plot vallen de twee geliefden elkaar gewoonlijk na de nodige omzwervingen in de armen, wat vervolgens bezegeld wordt met een huwelijk. Gerard toont dat hij deze conventie tot in de puntjes beheerst door het citeren van alle denkbare romantische clichés - de maneschijn, bedwelmend parfum, verleidingsscènes. Hij ondermijnt echter de authenticiteit van dat heteroseksuele romantische plot door zijn succesvolle parodie. Ook Herman kan het romantische plot niet dragen - die komt te vroeg klaar. De vierde man biedt echter geen geslaagde poging om een alternatief homoplot te formuleren of te legitimeren: Gerard ontmoet Herman niet eenmaal, en het hele verhaal blijkt een vergeefse poging om zijn geliefde Ronald aan zich te binden. Dit ondanks het feit dat de schrijver Reve vanaf het begin van de jaren zestig als geen ander expliciete beschrijvingen van homoseksualiteit mogelijk had gemaakt.

Het is niet toevallig dat Reves homoseksuele bedverhalen door critici werden ervaren als eindeloos en plotloos 'geleuter': kennelijk hebben die verhalen een te lang uitgesponnen middendeel. Juist als Gerards/Reves fantasie op volle toeren werkt wordt het plot als mislukt beschouwd. Terwijl de recensenten de spannende roman De vierde man over het algemeen waardeerden, twijfelt verteller Gerard juist aan de status van zijn verhaal. De vierde man poneert de vraag wat een man is en wat een verhaal is, en beantwoordt beide door middel van de tegenstelling hetero-homo. Heteroseksualiteit en het romantische plot zitten (nog) aan elkaar gebakken, zo moeten we concluderen - zie Brooks, en zie ook De vierde man - al heeft Reve de vanzelfsprekendheid van dat plot doeltreffend ontmaskerd. 



\section{4}

\section{BIJ HOOG EN BIJ LAAG \\ Vriend van verdienste van Thomas \\ Rosenboom}

Er hing zeker iets in de lucht: begin 2004, toen dit onderzoek al gestart was, bracht Jaap Goedegebuure het werk van Thomas Rosenboom (1956) ook al in verband met de gothic novel. In een stuk over de populariteit van de negentiende eeuw in hedendaagse romans schreef hij over Rosenboom: 'Archaïsmen, gezochte woorden, de parafernalia van de gothic novel of de conventies van de familieroman, hij heeft het allemaal in zijn fijnbewerktuigde vingers' (Goedegebuure 2004). Hoewel Goedegebuure geen titels noemt, is het hoogstwaarschijnlijk dat hij met die aanduiding 'gothic' doelde op Rosenbooms tweede boek, Vriend van verdienste (1985), dat in dit hoofdstuk centraal staat. Eigentijdse recensenten legden die relatie met de gothic novel indertijd niet. Adriaan Morriën (1986) en Aad Nuis (1985) noemden de roman wel 'sinister'; en Nuis plaatste de roman in de traditie van de Romantiek. Goedegebuure zelf, die Vriend van verdienste bij zijn verschijning ook recenseerde, vond het boek van een 'Teutoonse sfeer': 'duister, broeierig en mystiekerig'. Hij voegde daaraan toe:

Teutoon word je niet door je boekomslagen te laten ontwerpen in het schwarz-rot-weiss. Je pen moet bezield zijn van bos, bronst en bliksem. Schuld en boete zijn onontbeerlijk en je helden moeten geobsedeerd zijn door seks en macht. Willem Mertens is het standaardvoorbeeld en daarom is Van Oudshoorn onze vaderlandse proto-Teutoon. Natuurlijk bevinden zich er ook vele Teutonen binnen de grenzen van de Duitse literatuur. De Hoogromantiek geeft vele fraaie specimina te zien, maar onze eigen eeuw

\footnotetext{
${ }^{1}$ Een sterk bekorte versie van dit hoofdstuk verscheen in Andeweg (2005).
} 
kent ook uitstekende voorbeelden. Ernst Jünger hoort erbij en Kafka evenzeer, getuige alleen al zijn verhaal over de strafkolonie. Het hoogtepunt is Musils Verwirrungen des Zöglings Törless, een bedwelmende evocatie van sadomasochistische puberteitserotiek waarmee menige flagellant tot zijn gerief kan komen. (Goedegebuure 1986)

Goedegebuure vindt hier eigenhandig een Teutoonse literatuurtraditie uit, inclusief voorgangers en navolgers. Hij associeert die literatuur met een bepaalde taal/land (Duits) en een bepaalde thematiek (seks, schuld, boete, sadomasochisme, straf, macht). De keuze voor het woord 'Teutoons' is opmerkelijk. Het woord heeft een negatieve connotatie: het wordt gebruikt in de standaarduitdrukking 'Teutoonse horden' en geldt verder als geuzennaam in neonazistische kringen. Anders dan de gothic novel is de Teutoonse roman geen begrip. Maar Teutoons en gotiek zijn wel verwante woorden: beide verwijzen naar (barbaarse) Germaanse stammen, en beide hebben een negatieve bijklank (gehad). Voor mij laat deze karakterisering zien dat een gotiek interpretatiekader voor Nederlandse romans in 1985 niet voor het grijpen lag. ${ }^{2}$

Zo'n gotiek interpretatiekader ligt in het geval van Vriend van verdienste echter wel voor de hand. Setting, sfeer en plot van de roman zijn gotiek te noemen. Om te beginnen speelt de roman zich grotendeels af in een villa die gaandeweg verandert in een soort spookhuis. Daarmee grijpt Rosenboom terug op een van de favoriete decors van de gotieke roman: the haunted castle. De prominente plaats van kasteel, abdij of (land)huis blijkt uit het grote aantal gothic novels dat naar een specifiek gebouw vernoemd is, zoals The Castle of Otranto (Walpole), The House of Seven Gables (Hawthorne), The Fall of the House of Usher (Poe), The Mysteries of Udolpho (Radcliffe), Northanger Abbey (Austen), Bertram or the Castle of Aldobrand (Maturin), Nightmare Abbey en Crotchet Castle (Peacock) en Gormenghast (Peake). ${ }^{3}$ De villa in Vriend van verdienste behoort toe aan de familie Van Hal en is - zoals in veel gotieke romans - zelf haast een actor in het verhaal, met zijn 'overweldigende verschijning' (25). De naam van het huis, De Toorts, symboliseert het gezin Van Hal - een stamper met vijf meeldraden - maar draagt ook een omineuze lading. Hoewel de villa uiteinde-

\footnotetext{
${ }^{2}$ De verwijzing naar Musils roman is goed getroffen, want die kent een vergelijkbare thematiek: fysiek, psychologisch en seksueel geweld door jongens onderling. Musils roman is alleen niet vanuit het perspectief van het slachtoffer geschreven maar vanuit de meeloper/getuige Törless. Met dank aan Kathrin Lang.

${ }^{3}$ Over de rol van het huis of kasteel in de gotieke roman, zie: Railo (1927), Shelden (1974), Ellis (1989), Punter \& Byron (2004), p. 259-262; over het kasteel in hedendaagse gothic: Oakes (1999); voor Nederland: Buikema \& Wesseling (2006), met name p. 7-11.
} 
lijk niet in vlammen opgaat, wordt de temperatuur letterlijk en figuurlijk flink opgevoerd. ${ }^{4}$ Er zijn maar weinig Nederlandse romans die zo'n beklemmende sfeer weten op te roepen. De hittegolf die het huis en zijn bewoners teistert, is tekenend voor alles wat er tussen hen broeit. Het wekenlange verblijf van hoofdpersoon Theo Altink in het torenkamertje van de villa vormt het brandpunt van het verhaal, dat onafwendbaar op een catastrofe afkoerst.

Het geheime kamertje is ook een bekend gotiek motief, al geeft Rosenboom er een eigenzinnige draai aan. ${ }^{5}$ Theo wordt niet opgesloten, maar doet dat zelf: 'Gek: hij sloot zelf de deur achter zich' (117). Er is aanvankelijk geen duidelijke hiërarchie, zoals tussen een gevangene en zijn bewaarder. De aard van het gotieke raadsel verschuift daardoor: gewoonlijk is de inhoud van het kamertje de sleutel tot het raadsel, maar dat is nu geen bron van spanning meer. Het raadsel is eerder waarom Theo er (zo lang) blijft zitten. Hoewel echt bovennatuurlijke verschijnselen ontbreken, wordt hij uiteindelijk een spookachtige verschijning in de villa, net als moeder Van Hal. Een ander gotiek aspect is de fascinatie met kwaad, verval en lichamelijk lijden die uit de roman spreekt. Er zijn uitbarstingen van toenemend geweld, dat sadomasochistische trekken draagt. Het geweld is niet bevrijdend, maar schroeft de spanning alleen maar verder op. Pas wanneer na een maand eindelijk het onweer losbarst en er een dode valt, volgt een zekere ontspanning.

Vriend van verdienste draait als gezegd om de zestienjarige Theo Altink, die alleen met zijn vader, een caféhouder, een eindje buiten een niet bij name genoemd dorp woont. Zijn moeder is al tien jaar dood en zijn oudere broer Geert zit in een inrichting voor dwangopvoeding, wegens diefstal. Theo heeft een kraai, Rokko, die hij met veel geduld heeft weten te temmen, iets waar hij zeer trots op is. Hij wil vrienden worden met de welgestelde jongens Pieter en Otto van Hal, maar vooral met Otto, wiens verschijning op Theo onmiddellijk een immense indruk maakt:

Verbouwereerd had Theo hem zien rijzen, zijn lichaam was ontzaglijk. [...] Om niets stuk te maken en niemand pijn te doen deed hij [Otto] alles heel voorzichtig, alsof hij zelf ook wel wist dat hij eigenlijk te groot was, zelfs

\footnotetext{
${ }^{4}$ Er wordt wel op brand gezinspeeld aan het eind van de roman: 'Op de bovenste verdieping waren zo veel vensters verlicht dat het leek of er binnen brand was en de vlammen spoedig door het dak zouden slaan' (260).

${ }^{5}$ Denk aan het kamertje van Blauwbaard of aan Bertha Mason in Jane Eyre. Zie voor het 'locked room' motief in de gotieke roman: Madoff (1989), en voor het daarmee verwante 'locked trunk' motief Verhoeven (1995).
} 
voor de villa, maar tegelijk riepen zijn langzame bewegingen ook een dreiging van geweld op [...]. (30)

Otto's verschijning is nog imposanter dan die van de villa. Theo's vriend Freddie introduceert hem bij Otto en Pieter, die hij kent van school. Voor een feestje in de villa van de familie Van Hal steelt Theo frisdrank en snoepgoed; hij hoopt daardoor opgenomen te worden in de kring van Otto en Pieter. Theo belooft Otto om een sextant voor hem te stelen, waarmee hij definitief Otto's gunst denkt te kunnen winnen. ${ }^{6}$ Als hij een dag later wordt aangehouden door de politie omdat zijn brommer herkend wordt als gestolen, ontsnapt hij eerst uit het politiebureau en zoekt dan zijn toevlucht in de villa. Theo wil onderduiken, iets waar Pieter en Otto niets voor voelen, maar als Theo dreigt te onthullen dat Otto hem heeft opgedragen een sextant te stelen, stemt Otto alsnog in met Theo's verblijf. De jongens hebben het rijk alleen, omdat hun vader vrijwel altijd weg is, en hun moeder bij haar zus in het klooster verblijft.

Vanaf het moment dat Theo onderduikt krijgt Vriend van verdienste steeds meer gotieke trekjes. Theo's - in eerste instantie vrijwillige - opsluiting in het torenkamertje krijgt een steeds gruwelijker karakter, naarmate hij Otto, en ook Freddie, tot het uiterste weet te tergen door hen onder druk te zetten met de inmiddels gestolen sextant. Hij verandert langzamerhand in een gevangene, het geheim van de villa. Als de toestand na een maand nog steeds hetzelfde is, komen Pieter en Otto tot de conclusie dat ze Theo moeten vermoorden. Een eerste poging om Theo om te brengen, door hem pillen opgelost in bier laten drinken, mislukt. Dan schakelen de broers Freddie in om het vuile werk voor hen op te knappen. Ze doen Theo geloven dat hij naar het buitenland zal gaan, met Pieters paspoort, maar het plan is dat Freddie hem wurgt. Zo loopt het niet: Freddie ziet Pieter in het donker aan voor Theo en slaat Pieter neer, terwijl Theo ontsnapt.

Van alle romans die ik in dit boek analyseer valt Vriend van verdienste te typeren als de meest horrorachtige, vanwege zijn preoccupatie met (dreigend)

\footnotetext{
${ }^{6}$ Het valt overigens niet met zekerheid vast te stellen in de roman of Theo de sextant werkelijk steelt. Van de diefstal zelf wordt geen verslag gedaan, alleen van de voorbereidingen. Otto geeft Theo een tas, een schroevendraaier en zijn beloning (f 100,-), en geeft hem de opdracht de sextant achter de muur te zetten. Otto zal hem dan verstoppen: 'Morgen [...] zal ik het instrument gelijk begraven $[\ldots]$ we laten het dan een hele poos rusten, net zolang tot de zaak vergeten is' (58-59). Dit is een voorafschaduwing van Theo's eigen lot. Het volgende dat we erover lezen is dat Otto niets gevonden heeft bij de tuinmuur. 'Heb ik dan niet goed gezocht?' (127) vraagt Otto, wat door Theo wordt bevestigd. Aan het eind van de roman zegt Theo dat hij hem verborgen heeft 'in een konijnehol acher het tweede weiland, in het hakhout' (252). Voor het gemak spreek ik verder wel over de gestolen sextant.
} 
geweld en met het fysiek weerzinwekkende. ${ }^{7}$ Er zijn scènes die zich nauwelijks zonder walging laten lezen, zoals die waarin Theo uit zijn emmer met water en uitwerpselen drinkt. In wat volgt analyseer ik hoe het gotieke zich in deze roman manifesteert en wat het teweeg brengt. Zoals ik in hoofdstuk één uiteenzette, is het uitgangspunt dat het gotieke de culturele strategie bij uitstek is om fricties die veroorzaakt worden door processen van modernisering te verbeelden. In mijn analyse zal ik die fricties situeren in de Nederlandse maatschappelijke context van de jaren zestig.

In Vriend van verdienste concentreer ik me om te beginnen op botsende ideeën over vriendschap, en daaraan gerelateerde spanningen rond klasse en opwaartse mobiliteit. De gothic novel is vaak gelezen als verbeelding van het conflict tussen de opkomende moderne burgerij en de aristocratie die steeds verder onder druk komt te staan. ${ }^{8}$ Klasse en modernisering zijn daarmee haast vanzelfsprekende thema's voor analyse in gothic criticism. In Nederland is klasse, al dan niet ten onrechte, veel minder een onderwerp van analyse in de literatuurwetenschap. Ook in de geschiedschrijving over naoorlogs Nederland worden eerder verschillende generaties of verschillende zuilen tegenover elkaar geplaatst, dan verschillende klassen. ${ }^{9}$ Door Vriend van verdienste te lezen vanuit een gotiek interpretatiekader valt op wat voor centrale en conflictueuze rol klasse speelt in deze roman en hoe relevant klasse als analysecategorie kan zijn. Het is een van de belangrijkste motoren achter de ontsporingen in het verhaal.

Vervolgens besteed ik aandacht aan de manier waarop in deze roman gotieke grensoverschrijdingen geënsceneerd worden in termen van zuiverheid en onzuiverheid. In deze meerdimensionale roman laat het gotieke zich niet vastpinnen op één tegenstelling. Behalve klasse komen ook categorieën als mannelijkheid en seksualiteit onder druk te staan. Wat gebeurt er als klassenverschillen genegeerd worden? Als de grenzen tussen vriendschap en erotiek vervagen? Als het verschil tussen waarheid en leugen er niet meer toe doet? Bij de beantwoording van deze vragen gebruik ik de theorieën van Robert Mighall (1999), Julia Kristeva (1982) en Eve Sedgwick (1985). In Vriend van verdienste vervagen

\footnotetext{
${ }^{7}$ In zijn Anatomy of Disgust (1997) definieert William Miller horror als de combinatie van angst en walging. Zowel dreiging (die angst veroorzaakt) en onzuiverheid (die walging veroorzaakt) zijn vereist (p 25-26).

${ }^{8}$ Zie bijvoorbeeld Botting (2001 [1996]), p 5-6, Miles (1995) en Clery (1995).

${ }^{9}$ Wat betreft geschiedschrijving over de jaren vijftig: Luykx \& Slot (1997), Schuyt \& Taverne (2000); jaren vijftig en zestig bijvoorbeeld Von der Dunk (1986), op het gebied van literatuurgeschiedschrijving Ruiter \& Smulders (1996). Geschiedschrijving over jaren zestig: zie Righart (1995) (dat als ondertitel 'Geschiedenis van een generatieconflict' heeft) en Kennedy (1995, 1997).
} 
allerhande grenzen die de maatschappelijke orde in stand moeten houden; ook de grens tussen gevangene en bewaarder, tussen dader en slachtoffer, en tussen goed en kwaad. Er staat in deze roman zoveel op het spel dat extreem geweld intrinsiek onderdeel wordt van de onderlinge verhoudingen.

\section{EEN HISTORISCHE ROMAN}

Vriend van verdienste is gebaseerd op een waargebeurde moordzaak uit 1960, die bekend staat als de Baarnse moordzaak. ${ }^{10}$ De roman is echter duidelijk een fictieve verwerking daarvan. Allerlei elementen zijn anders dan in de feitelijke zaak - de leeftijd van de hoofdpersonen, het jaar van handeling, beroepen van de vaders, familiesamenstelling, kleding, ja zelfs de afloop verschilt. Wat bovendien in de moordzaak per definitie niet mogelijk was, doet deze roman wel: het verhaal wordt grotendeels gefocaliseerd door het slachtoffer.

De roman speelt zich af in 1966, zes jaar later dan de historische moordzaak. ${ }^{11}$ Rosenbooms roman verscheen in 1985 . Er ligt dus maar krap twintig jaar tussen het moment van handeling en moment van verschijnen. Het contrast tussen romanheden (1966) en publicatiejaar (1985) had echter niet groter kunnen zijn. Het beeld van 1966 dat Rosenboom schetst in Vriend van verdienste doet archaïsch aan. Dat komt met name door Rosenbooms karakteristieke stijl en vocabulaire. ${ }^{12}$ Die bijzondere stijl werd door alle recensenten gememoreerd, soms als 'precieus ouderwets' (Verbogt 1986), dan weer simpelweg als 'markant' (Nuis 1985). De een waande zich verdwaald in Van Schendel, anderen vergeleken hem met Reve of met 'negentiende-eeuwse vertalingen van Fla-

\footnotetext{
${ }^{10}$ In oktober 1961 werd in een put vol ongebluste kalk bij een villa in Baarn het lijk ontdekt van Theo Mastwijk, die ruim een jaar daarvoor was verdwenen. Hij bleek door twee broers uit de villa en een vriend te zijn vermoord, na weken te hebben doorgebracht in het torenkamertje. Rosenboom verklaarde in diverse interviews dat hij de rechtbankverslagen van deze geruchtmakende zaak als inspiratiebron gebruikte, zie bijvoorbeeld Ruyter (1986) en Mertens (2000). De moordzaak sprak en spreekt tot de verbeelding: Johan Fabricius schreef er een roman over, Jongensspel (1963), Manuel van Loggem een toneelstuk dat regelmatig is opgevoerd (Jeugdproces 1963, opnieuw verschenen in 1977). In 2008 verscheen een op de moordzaak gebaseerde film Bloedbroeders (regie Arno Dierickx). Lennart Nijgh beschreef de zaak in een bundel over 12 beroemde Nederlandse moordzaken, Moord en Doodslag (1991). Rosenbooms roman werd op zijn beurt door Yves Jansen bewerkt tot toneelstuk (ook getiteld Vriend van verdienste, 1996).

${ }^{11}$ Het enige jaartal dat in de roman expliciet vermeld wordt, 1956, is het jaar dat de moeder van hoofdpersoon Theo Altink overleed. Theo was toen zes, in het romanheden is hij zestien.

${ }^{12}$ Vergelijk de gewoonte om films die in de eerste helft van de twintigste eeuw spelen een sepiakleurstelling te geven - daarmee wordt een nadrukkelijk contrast tussen heden en verleden aangebracht.
} 
vius Josephus' (Schouten 1986). Men vond, met andere woorden, dat Rosenbooms woordgebruik niet van de tijd was waarin de roman speelt: 'Eigentijdse woorden en zinsneden zijn bij hem ver te zoeken. De Baarnse moordzaak speelt in het begin van de jaren zestig. En hier en daar, in de beschrijving van attributen, herken je die tijd. Maar Rosenbooms taal is niet van die tijd.' (Matthijsse 1986). Ter vergelijking: Johan Fabricius' roman uit 1963 over dezelfde Baarnse moordzaak doet qua taalgebruik veel eigentijdser aan.

Elementen uit het moderne leven lijken in Rosenbooms roman praktisch te ontbreken, vooral in de villa. Bij Freddie thuis is een televisie, maar in de beschrijvingen van de villa wordt de aandacht juist gevestigd op de kroonluchters. ${ }^{13}$ Theo ervaart een contrast tussen de muziek die hij bij hem thuis op de radio hoort, en de klassieke muziek (Richard Strauss) op de pick-up bij Otto en Pieter. Details over kleding en haardracht in Vriend van verdienste bevestigen het beeld van een tijd die voorbij is. De jongens dragen op de middelbare school een jasje $(21,26)$, overhemd en das (166). Ze kammen (26) of plakken (82) hun haar glad achterover. Ze dansen de quick step of een slow-fox, populaire muziek als rock ' $\mathrm{n}$ roll valt buiten hun blikveld. Als Freddie in de beslotenheid van zijn eigen kamer toch eens een 'vrije dans' doet, met zijn armen zwaait en zijn haren voor zijn ogen heen en weer laat bungelen, vindt Theo, die hem bespiedt, hem 'een wildeman' (83).

Het moge duidelijk zijn: hier zijn hippies, provo, de seksuele revolutie en de democratisering van het hoger onderwijs (nog) ver weg. Voor zover er maatschappelijk rumoer is, dringt dat niet door tot het wereldje van de jongens. Het tijdsbeeld in de roman beantwoordt eerder aan clichés van braafheid en orde, dan aan iets wat tegenwoordig met 'de jaren zestig' wordt geassocieerd. ${ }^{14}$ Maar onder het brave oppervlak borrelt en gist het. Rosenbooms verplaatsing van de handeling van 1960 naar $1966 \mathrm{kan}$ als een betekenisvolle ingreep geïnterpreteerd worden. De achternaam van Otto en Pieter - Van Hal - roept associaties

\footnotetext{
${ }^{13}$ Ter contrast: de zinspeling op het nog schaarse televisiebezit doet in Fabricius' roman eigentijds aan: 'Moeder (de moeder van de jongens uit de villa, AA) gaat naar de televisie kijken bij mevrouw Verbruggen' (Fabricius 1963, 5).

${ }^{14}$ Diverse studies hebben de afgelopen jaren het clichébeeld van de brave jaren vijftig en begin jaren zestig bijgesteld: wat eind jaren zestig gebeurde was niet zozeer een revolutie, als wel een verhevigde voortzetting van ontwikkelingen die al gaande waren (Schuyt \& Taverne (2000), Luykx \& Slot (1997), Meijer (1999), Von der Dunk (1986). Dat doet echter niets af aan de kracht van het clichébeeld zoals dat in deze roman geschetst wordt. Om een indruk te geven van de gebeurtenissen in 1966: eind maart waren er relletjes tijdens het huwelijk van Beatrix en Claus, studenten demonstreerden tegen de plannen van minister Diepenhorst; onbemande ruimtevaartuigen landden op de maan; de Beatles, de Rolling Stones en de Beach Boys brachten een nieuw album uit.
} 
op met Van Hall, die in 1966 de burgemeester van Amsterdam was. In 1967 werd hij gedwongen af te treden: Van Hall werd beschouwd als een vertegenwoordiger van de regentenmentaliteit die de jongerenprotesten in zijn stad niet begreep. ${ }^{15}$ Het Polygoon jaaroverzicht noemde 1966 het jaar van de jeugdproblematiek - een term die ook koningin Juliana in haar troonrede gebruikte - en verklaarde: 'Nederland was ineens niet meer het land van het knusse Hollandse binnenhuisje' (Van geval tot geval, 1966). Righart (1995) heeft een hoofdstuk met als titel 'Het rampjaar 1966'. Vriend van verdienste geeft een eigen, nietgrootsteedse versie van dit 'rampjaar'. De roman presenteert het conflict tussen de moderne jeugd en de regentenfamilie Van Hal op microniveau en laat ons zien hoe het er in dit Hollandse binnenhuisje aan toegaat.

In 1985 ziet Nederland er heel anders uit dan in het 1966 dat Rosenboom schetst. In dat opzicht is Vriend van verdienste zeer vergelijkbaar met de klassieke gotieke roman, die vaak in het (premoderne) verleden gesitueerd is. Het kan de hedendaagse lezer het comfortabele gevoel geven dat de gotieke gruwelen uit de roman 'uit de tijd' zijn, definitief vervangen door de moderne hedendaagse verhoudingen. Dat is aanleiding om aandacht te besteden aan mogelijke spanningen tussen moderniteit en traditie in Vriend van verdienste. Die spanningen komen allereerst tot uiting in contrasterende opvattingen over vriendschap en klasse.

\section{VRIENDSCHAP VERDIENEN: OVER DE GRENZEN VAN KLASSE}

Het begint allemaal zo onschuldig, met Theo's wens tot vriendschap: 'Als hij zich tenminste maar eens in zijn dienst mocht stellen; de vriendschap zou vervolgens niet uit kunnen blijven' (23) denkt Theo over Otto. Theo verwacht dat erkentelijkheid voor zijn bewezen diensten zal leiden tot zijn erkenning als vriend. Hij vat de band tussen twee vrienden op als in beginsel hiërarchisch, en niet als een band van emotionele gelijkheid. Theo kan dan ook beter uit de voeten met de hooghartige houding van Otto, dan met de vriendelijkheid van Pieter. Dat blijkt uit zijn reacties op Pieters vriendelijke houding. Wanneer Theo Pieter enthousiast vertelt over zijn getemde kraai, laat Pieter Theo zijn pijl en boog zien. Hij doet voor hoe het moet en overhandigt Theo de boog met de plechtige woorden: 'Jij en ik, Rokko en de boog' (34), daarmee hen beiden tot

\footnotetext{
${ }^{15}$ Zie Righart (1995) p. 211-235, voor een analyse van Van Halls houding tegenover de provo's, zijn rol bij het huwelijk van Beatrix en Claus en bij het zgn. Bouwvakoproer, alle in 1966.
} 
jager verklarend. Als Theo er vervolgens niet in slaagt om de boog goed te spannen en een pijl af te schieten, moet hij huilen. Hij schaamt zich daar diep over - en hij reageert die schaamte af met gevoelens van 'plotselinge minachting' (38) voor Pieter: 'Pieter had hem getroost toen hij bij het schuurtje had gefaald, zo erg dat hij zich vervolgens niet meer had kunnen bedwingen, maar Otto en Freddie hadden hem gehoond om de vouw in zijn blouse... Naar hen moest hij toe!' (38). Theo zoekt liever hoon dan troost. Zwakheid die door de ander gezien en begrepen wordt, is beschamender dan vernedering. Met Pieters aanbod van vriendschap, dat lijkt uit te gaan van gelijkwaardigheid - uitgedrukt in een formule met twee nevenschikkingen: 'jij en ik; Rokko en de boog' - kan Theo helemaal niet omgaan.

Waarom onderwerpt Theo zich liever aan Otto dan dat hij Pieters uitgestoken hand accepteert, terwijl vriendschap toch zijn doel is? Mijns inziens heeft dat te maken met twee verschillende hiërarchieën die hier in het geding zijn: een 'zakelijke' hiërarchie en een 'emotionele' hiërarchie. Een zakelijke hiërarchie, zoals tussen baas en ondergeschikte, is niet vernederend, maar vormt in Theo's ogen juist de koninklijke weg naar vriendschap. De emotionele hiërarchie - wie heeft zijn emoties onder controle en wie niet - gaat wel met vernedering gepaard, namelijk voor degene die zijn emoties niet kan beheersen. Deze twee hiërarchieën kunnen gerelateerd worden aan twee verschillende opvattingen van vriendschap.

Volgens historica Dorothée Sturkenboom werd vriendschap in de vroegmoderne tijd 'door velen als een instrument opgevat dat vooral diende ter ondersteuning van de maatschappelijke en materiële positie. Het was minder persoonsgebonden en eerder op economische noodzaak dan op genegenheid gebaseerd. Deze pragmatische vriendschapsopvatting was de dominante vriendschapsopvatting in de vroegmoderne tijd' (Sturkenboom 1998, 326). ${ }^{16}$ Pas in de moderne opvatting, die eind achttiende eeuw gangbaar werd, werd vriendschap meer opgevat als een 'geestelijke, niet-zinnelijke liefde' (Sturkenboom 1998, 325), een emotionele band tussen gelijkgestemden.

De moderne vriendschapsopvatting is inmiddels verreweg dominant, maar Theo lijkt er een vroegmoderne opvatting van vriendschap op na te houden. Hij kiest als uitgangspunt voor vriendschap de pragmatische, zakelijke, en niet de emotionele relatie. De vriendschap die hij voor ogen heeft met Otto is in eerste instantie instrumenteel, gebaseerd op het verlenen van diensten. Uit die

\footnotetext{
${ }^{16}$ Volgens Luuc Kooijmans waren moderne opvattingen van vriendschap al wel eerder te vinden (behalve in de klassieke oudheid o.a. bij schrijvers als Coornhert en Montaigne), maar werden ze pas algemeen gangbaar door toenemende institutionele zekerheden en groeiend individualisme (Kooijmans 1997, 14-15; 326-329).
} 
dienstverlening zou de vriendschap zich moeten ontwikkelen - misschien tot een moderne vorm, al worden Theo's ideeën daarover niet geëxpliciteerd. We kunnen Theo's ideeën over vriendschap lezen als een anachronisme: op dit punt botsen pre- (of vroeg-)moderne opvattingen in de roman met moderne.

Moderne vriendschap is gebaseerd op het delen van gevoelens en op gelijkwaardigheid. Die gelijkwaardigheid bestaat bij de gratie van wederkerigheid. In de scène met Pieter is Theo de enige die zijn emoties toont, en dat ervaart hij als een vernedering. Hij vindt Pieters vriendelijkheid 'dwingend' (38). Van Pieters perspectief weet de lezer niets, de scène wordt gefocaliseerd door Theo. Het valt dus niet uit te maken of Pieter zijn vriendelijkheid oprecht uitnodigend of eerder badinerend bedoelt.

Het beheersen van bepaalde emoties, zoals verdriet, en het ontkennen van (emotionele) kwetsbaarheid valt in twee verschillende repertoires te plaatsen: van mannelijkheid en van volwassenheid. Het niet-tonen van verdriet behoort tot een oud repertoire van mannelijkheid - echte mannen huilen niet. ${ }^{17}$ Ook de tegenstelling kind-volwassene wordt vaak in termen van zelfbeheersing gevat: huilen is kinderachtig. Dat repertoire van zelfbeheersing wringt met de moderne opvatting van vriendschap als een relatie die juist gebaseerd is op het delen van gevoelens, zeker als maar een van de twee vrienden zijn emoties toont. Theo lijkt slechts in staat om in termen van hiërarchie te denken. Hij vat het tonen van emoties in hiërarchische termen op, en loopt dus naar eigen maatstaven het risico zijn mannelijkheid of zijn volwassenheid te verliezen. Dat verklaart zijn gevoelens van vernedering.

In de 'oude' opvatting van vriendschap hoeven hiërarchieën, oftewel machtsverschillen, niet problematisch te zijn - integendeel, die vormen het uitgangspunt -zolang beide partijen het zakelijk houden en hun materiële positie kunnen bestendigen. Zo beschouwd is Theo's vriendschapsopvatting heel passend, want zijn uitgangspositie ten opzichte van de andere jongens is nauwelijks gelijkwaardig te noemen. De relaties tussen hem en Otto en Pieter, maar ook met Freddie worden van meet af aan bepaald door machtsverschillen. Zo is Theo de jongste van de vier, en daarmee staat hij automatisch onder aan de ladder.

\footnotetext{
${ }^{17}$ De eis van zelfbeheersing is selectief, en heeft een verschillende inhoud voor mannen en vrouwen. Voor mannen geldt die eis bijvoorbeeld veel minder op het terrein van autoriteit en agressie. Voor vrouwen komt de eis van zelfbeheersing al snel neer op bescheidenheid. Voor een analyse van mannelijkheid in hedendaagse cultuur zie bijvoorbeeld West \& Lay (2000); voor een analyse van sekse en emotionele cultuur in de $18^{\mathrm{e}}$ eeuw zie Sturkenboom (1998). Over zelfbeheersing en moderniteit schreef Norbert Elias de invloedrijke studie Über den Prozess der Zivilisation; Soziogenetische und psychogenetische Untersuchunge (1939).
} 
Belangrijker nog dan de leeftijdshiërarchie is het klassenverschil. Otto en Pieter van Hal zijn de zonen van een rechter, en behoren dus tot de hogere klasse. Ze wonen in een enorme villa vol antieke meubels, die hun status en macht onderstreept. Als Theo de villa voor het eerst ziet vindt hij dat die 'een orde uit[drukt] van plechtigheid en recht' (25). Een navrante observatie, in het licht van de latere gebeurtenissen. De familie Van Hal heeft een huishoudster, Dorien, in dienst en bezit een tweede huis in Zwitserland. De vaders van Theo en Freddie staan een stuk lager op de maatschappelijke ladder. Zij zijn kleine zelfstandigen, middenstanders: Theo's vader drijft een café, Freddies vader heeft een houthandel. Freddie is net als Theo een kruimeldief, in dienst van Otto. Zoals hun vaders hun klanten drank en hout leveren, zo leveren Freddie en Theo 'bestellingen' (137) aan Otto.

Het klassenverschil is bepalend voor de verschillende betekenissen die dienstbaarheid voor de jongens heeft. Dienstbaarheid is voor Theo een deugd, een kwestie van (middenstands)eer, en behalve een manier om aan geld te komen ook verbonden met vriendschap, zoals ik liet zien. In feite heeft Theo zich vereenzelvigd met de moraal van een dienstbare klasse, de middenstand waartoe hij behoort. Voor Otto heeft dienstbaarheid niets met deugd of met vriendschap te maken. Zijn overeenkomst met Theo is voor hem louter een zakelijke transactie - daar betaalt hij voor. Theo heeft van de (economische) nood een deugd gemaakt, terwijl daar voor Otto geen enkele anleiding toe is. Die twee verschillende betekenissen zijn vervat in de titel van de roman, 'vriend van verdienste'. 'Verdienste' kan een verdienste in economische zin zijn, of een verdienste in de zin van aanspraak op lof en erkentelijkheid. Dat betekenisverschil ligt ten grondslag aan het misverstand dat bij Theo postvat: dat via (zakelijke) dienstbaarheid vriendschap met Otto bereikbaar is.

Theo's anachronistische opvatting van vriendschap botst met de opvattingen van Pieter en Otto. De moderne vriendschap op basis van gelijkwaardigheid die Pieter hem lijkt aan te bieden, is door Theo niet te bevatten, de op dienstbaarheid gebaseerde vriendschap die hij nastreeft met Otto wordt door Otto niet gehonoreerd. Klassenverschillen zijn bepalend voor wat denkbaar en mogelijk is. De houding van de jongens ten opzichte van dat klassenverschil is in de roman diep ambivalent: nu eens wordt het genegeerd, dan weer wordt het benadrukt. In de volgende paragraaf geef ik daar voorbeelden van. 


\section{KLASSENVERSCHIL EN GENDER}

Klassenverschillen in Vriend van verdienste zijn gegenderd. Daarmee bedoel ik dat de hiërarchische verhouding tussen hoog en laag wordt uitgedrukt in termen van mannelijkheid en vrouwelijkheid, waarbij mannelijk staat voor 'hoog', en vrouwelijk voor 'laag'. Een aantal keren wordt er door de jongens expliciet gerefereerd aan de hogere klassen, altijd in de vorm van staande uitdrukkingen, gestolde formules waarin heren, gentlemen, het referentiepunt zijn. Zo zegt Pieter tegen Theo: 'Heren eten niet van de grond' (131), als Theo zijn intrek neemt in het torenkamertje van de villa en op zolder wat meubelstukken uit mag zoeken. Ook Freddie weet hoe het hoort. Hij heeft bij elke gelegenheid een passende spreuk. 'A gentleman never pops the bottle' (250) zegt hij, als Otto ter ere van Theo's verjaardag een fles champagne ontkurkt in het torenkamertje. Een derde voorbeeld komt ook van Freddie. Als hij Theo's vader bespiedt, terwijl die gehurkt bloemen aan het plukken is in de boomgaard achter het café, wordt hij overvallen door een plotselinge haat jegens de man. Die komt onder andere voort uit het feit dat Theo van zijn vader niet meer met Freddie mocht omgaan vanwege zijn slechte invloed. Hij registreert de bruine kleur van de baksteen van het huis, het bruine overhemd dat Theo's vader draagt, en de bruine pigmentvlekken op zijn hoofd, en denkt vervolgens: 'A gentleman never wears brown' (179). Het is duidelijk, het bruin kleeft deze man aan, hij zal nooit een gentleman zijn. Freddie loopt over van minachting voor Theo's vader: 'Zo verdient hij het dagelijkse brood, mijmerde hij, tappend voor de boeren en het ruige volk...en ik was een bederf' (182). Hij voelt zich ver verheven boven de man die door zijn beroep zelfs nog aan de lagere klassen dienstbaar moet zijn, en drukt dat uit met een term - bederf - die onderdeel is van een vertoog over zuiverheid. Ook het bruin, hier een teken van 'laag', wordt in een vertoog over zuiverheid geplaatst. Ik kom daar in de volgende paragraaf op terug. Freddie neemt nadrukkelijk afstand van Theo's vader, die hem even vertrouwd is als zijn eigen familie ('alles kende hij van hem'). Hij wil zich de gewoontes van een gentleman aanmeten, 'he wants to rise above his station' zoals dat heet in de Britse maatschappij die geobsedeerd is door klasse. Maar je gedragen als een gentleman maakt nog niet dat je er een wordt. Freddies kennis over gentlemen is oppervlakkig, het formuleachtige karakter van zijn kennis benadrukt dat: hij spreekt uitsluitend in clichés.

Tegenover de mannelijkheid van de hogere klasse (heren, gentlemen) staat de vrouwelijkheid waarmee de lagere klasse wordt geassocieerd. Dienstbaarheid en vrouwelijkheid worden met elkaar verbonden. Freddie vergelijkt Theo's bloemen plukkende vader in de hierboven aangehaalde scène met een bruid: 'de 
ontroerde bruid, op weg naar het altaar' (179). Over Theo lezen we dat hij altijd zijn eigen kamer schoonmaakt, de was strijkt, de keuken dweilt en het graf van zijn moeder netjes schoonhoudt. Hij doet dat typische vrouwenwerk niet met tegenzin, maar legt er eer mee in. Het schoonmaakwerk geeft hem in de roman dezelfde structurele positie als Dorien, de huishoudster van de familie Van Hal. Het klassenverschil tussen Otto en Theo wordt via deze vrouw gemarkeerd.

Als Theo Otto heeft beloofd een sextant voor hem te zullen stelen, nodigt de laatste Theo uit om even op de rug van Dorien te gaan zitten. De vrouw ligt in hun aanwezigheid op haar knieën de vloer te boenen. Otto vertelt dat hij vroeger ook altijd op haar rug zat, omdat zijn moeder vond dat de vloer dan beter werd gewreven. Otto's uitnodiging impliceert gelijkheid tussen hem en Theo, hun deal wordt met dat gebaar beklonken, letterlijk over de rug van Dorien. Theo is echter hevig gegeneerd en durft niet echt te gaan zitten. Vanuit Theo's gevoel voor hiërarchie is dat ook begrijpelijk: hij wilde zich aan Otto onderwerpen; een gelijkwaardige positie is voor hem niet voorstelbaar. Zijn gêne plaatst hem op gelijke voet met Dorien, wier commentaar overigens niet gehoord wordt. De fysieke enscenering van de hiërarchische verhouding tussen Otto en Dorien, door Otto als volkomen vanzelfsprekend voorgesteld, grenst aan sadisme. Diezelfde vanzelfsprekendheid van het klassenverschil tussen de familie Van Hal en Dorien komt naar voren als Pieter Theo vertelt dat de familie op vakantie gaat naar het tweede huis in Zwitserland: '[Z]elfs Dorien gaat mee, met haar echtgenoot. Dat is al een oude traditie, ze reizen dan een dag vooruit om alles al vast in orde te maken. Voor hen is het ook min of meer vakantie' (208). Een huis in orde maken is Doriens dagelijks werk - in hoeverre ze dat zelf als vakantie ervaart is maar de vraag.

Het is opvallend dat klassenverschil vooral via anderen (Theo's vader, Dorien) zichtbaar wordt gemaakt. Tussen de jongens onderling wordt het verschil niet benoemd. Freddie zit bij Otto en Pieter op school, wat een zekere gelijkheid impliceert. Pieter en Otto lijken met hun gedrag (ga ook even op de rug van Dorien zitten, heren eten niet van de grond) ook Theo in hun kring op te willen nemen. $\mathrm{Zij}$ doen alsof er geen verschillen bestaan: als Pieter tegen Theo praat over zijn jolletje ('Kun jij eigenlijk zeilen, heb je dat wel eens gedaan?' (209)) lijkt hij niet te beseffen dat zeilen voor Theo een ondenkbare hobby is. Andersom lijkt Theo ongevoelig voor een mogelijk statusverschil tussen Pieters uitgebreide scheikundeset en zijn ene flesje gif en zijn 'broeiberg', waarmee hij naar eigen zeggen ook stoffen met elkaar verbindt. Pieter op zijn beurt doet laconiek over zijn bezit: 'ik heb die spullen nu eenmaal' (122). Op deze momenten gedraagt met name Pieter zich alsof vriendschap mogelijk is, in de vorm 
van een (emotionele) band tussen gelijkgestemden, waarbij materiële positie er niet toe doet: een moderne vriendschap dus.

Toch blijken de verschillen tussen Theo en Freddie enerzijds, en Otto en Pieter anderzijds, onoverbrugbaar. Die onoverbrugbaarheid blijkt op de momenten dat er door Theo of Freddie een appèl op Pieter of Otto wordt gedaan. Zo houdt Otto Freddies verzoek af om hem te mogen bezoeken als hij op kamers gaat - dat is 'een heel ander milieu' (174) zegt Otto dan. En als Theo Pieter vraagt of hij voor hem zal blijven zorgen, antwoordt Pieter nonchalant: 'Je moet toch ergens voor zorgen' (186) - niet voor iemand, maar voor iets. De (klassen)grens wordt zo, ondanks suggesties van het tegendeel, toch zorgvuldig gesteld. Zolang Pieter en Otto de voorwaarden van de relatie kunnen bepalen, zoals de redenen waarom Theo in de villa komt (om een diefstal af te spreken, om drank te brengen) is er niets aan de hand. De arrogantie van de macht stelt hen in staat om zelfs een zekere welwillendheid uit te stralen. Maar zodra Theo zijn intrek in het torenkamertje heeft genomen, en de villa dus fysiek is binnengedrongen, komen de zaken anders te liggen. Theo heeft de ongeschreven regels overtreden, en dan worden de reactie van de broers op toenaderingen van Theo (en ook Freddie) expliciet afwijzend. Na Theo's eerste nacht in het kamertje zegt Otto tegen hem: 'Ik wil jou niet beter leren kennen' (158). En Freddie ontmoet alleen minachting van de broers bij zijn poging om zich aan Pieters en Otto's zijde te scharen, als Theo hen met zichzelf heeft opgezadeld.

Freddie blijft in de veronderstelling verkeren dat vriendschap met iemand uit de hogere klasse denkbaar is, dat hij op gelijke voet kan staan met de jongens uit de villa en dat het mogelijk is om een gentleman te worden door je de juiste gewoontes aan te meten. Hij vertegenwoordigt met andere woorden een (moderne) overtuiging dat opwaartse mobiliteit mogelijk is door opleiding en individuele ontwikkeling. Theo is ambivalenter: hij wil wel vriendschap sluiten maar kan zich een gelijkwaardige band in feite niet voorstellen. Hoewel Pieter en Otto in eerste instantie het spelletje van de gelijkwaardige omgang meespelen, krijgt de overtuiging dat zo'n gelijkwaardige omgang niet mogelijk (of wenselijk) is en door verschil in afkomst c.q. vaders positie wordt verhinderd de overhand, zodra Theo fysiek dezelfde ruimte inneemt als zij. Als hij zijn intrek neemt in de villa raken er categorieën vermengd die gescheiden hadden moeten blijven. Het resultaat van Theo's infiltratie is niet zomaar onzuiver, maar abject. 


\section{ZUIVERHEID EN HET ABJECTE}

Met behulp van de begrippen zuiverheid en het abjecte valt het proces te verhelderen dat Theo doormaakt in het torenkamertje. Zuiverheid was lang een onderzoeksthema voor antropologen (Douglas 1966), maar inmiddels houden ook filosofen, sociologen en historici zich ermee bezig (Kristeva 1982, Lévy 1994, Moore 2000, Labrie 2001). Het zuivere is een bijzonder soort categorie; een die het verschil tussen wat onvermengd (zuiver) en vermengd (onzuiver) is zelf categoriseert. Het maken van onderscheid is dus cruciaal voor een mogelijke definitie van wat zuiver is. Zuiver is niet alleen het onbesmette, het kuise of het onschuldige, maar ook de toestand waarin een duidelijk onderscheid tussen zuiver en onzuiver bestaat. Het abjecte daarentegen ontstaat als dat duidelijke onderscheid tussen zuiver en onzuiver verdwijnt.

In The Powers of Horror (1982) onderzoekt filosofe Julia Kristeva het abjecte als een aspect van identiteit. Zelfdefinitie bestaat bij de gratie van uitsluiting van het abjecte, aldus Kristeva. Het proces van 'abjection' (vertaald als abjectie) dient om vast te stellen wat wel tot het menselijke zelf behoort en wat niet. Vormeloosheid, vermenging en troebelheid bedreigen het zelfbeeld: 'It is thus not a lack of cleanliness or health that causes abjection but what disturbs identity, system, order. What does not respect borders, positions, rules. The inbetween, the ambiguous, the composite' (Kristeva 1982, 4). Als grenzen vervagen wordt het systeem en/of de eigen identiteit ondermijnd. Kristeva noemt een rottend lijk als het ultieme voorbeeld van het abjecte, omdat daar categorieën worden vermengd - dood en leven - die normaliter strikt gescheiden horen te blijven.

Abjectie is een gevolg van overschrijden van de grenzen van de maatschappelijke orde en van duidelijk omlijnde identiteiten. Het is niet verwonderlijk dat de gotieke roman, en moderne verschijningen van het gotieke zoals de horrorfilm, zo'n obsessie vertonen met zuiverheid en het abjecte. Vanuit de opvatting dat via het gotieke conflicten rond modernisering verbeeld kunnen worden is zo'n obsessie begrijpelijk. Arnold Labrie (2001) laat in zijn cultuurhistorische studie over Europees verlangen naar zuiverheid zien hoe moderniteit en de hang naar zuiverheid aan het begin van de twintigste eeuw nauw met elkaar verbonden zijn. Labrie stelt dat de burger enerzijds het moderne vooruitgangsdenken belichaamt, maar anderzijds een middenpositie inneemt in de samenleving, waardoor hij zich eerder bedreigd voelt. Labrie wijdt een uitgebreide bespreking aan zuiverheid en onzuiverheid in de gothic klassieker Dracula. Labrie beschrijft ook hoe (religieuze) rituelen van oudsher dienen om het abjecte uit te bannen. 
Die rituelen hebben niet alleen een religieuze, maar ook een maatschappelijke functie: door de uitbanning van het abjecte wordt de orde hersteld.

Vriend van verdienste is op allerlei niveaus doortrokken van een vertoog over zuiverheid. Ik noemde al hoe Freddie klasse in termen van zuiverheid uitdrukt. De hogere klasse associeert hij met zuiverheid; het bruin dat Theo's vader aankleeft met de lagere klasse. Daarom is hij verontwaardigd dat de man hem een 'bederf durfde te noemen. Theo is bezeten door zuiverheid, uiterlijk maar vooral innerlijk. Op weg naar de villa is hij verguld met zijn nieuwe witte sokken, de witte vlakken op zijn zwart-wit geblokte blouse, zijn hagelwitte tanden en het witte pepermuntje: 'het [was] alsof de zuiverheid zich vanuit zijn voeten verbreidde en zijn gehele lichaam doortintelde' (62). Afgezien van dit ene moment is het ideaal van innerlijke, morele zuiverheid nauwelijks bereikbaar. Theo vindt zichzelf vaak een 'slechte jongen', omdat hij tegen de wil van zijn vader met Freddie omgaat en omdat hij steelt. Hij wil zichzelf verbeteren maar slaagt daar maar niet in. Hij bezoekt regelmatig het graf van zijn moeder, dat hij zorgvuldig schoon houdt, om aan haar zijn zonden te biechten. $\mathrm{Zij}$ is voor hem het symbool van ultieme zuiverheid. ${ }^{18}$ Als Theo Rokko een keer heeft meegenomen naar zijn moeders graf voelt hij zich schuldig, omdat hij met de 'slechte vogel' (een dief en een lijkenpikker immers) die zuivere plek bezoedeld heeft.

In zijn seksuele fantasieën is Theo de onschuld zelve. Hij fantaseert over Agnes, de vriendin van Otto die bij Pieter en Freddie in de klas zit, en die hij op het feestje in de villa heeft ontmoet. Hoewel hij Agnes na die eerste avond een 'slet' noemt - ze heeft niet alleen Otto gezoend maar ook Theo een afscheidskus gegeven -, verschijnt zij in zijn dromen als een toonbeeld van zuiverheid en kuisheid. ${ }^{19}$ In zijn eerste fantasie ziet hij Agnes neerhurken 'zodat hij op de verdenking kwam dat zij misschien zat te plassen' (62), maar als hij de plek voelt is 'het gras [...] droog en rook heerlijk fris' (62). Op dat moment is Theo even zuiver als zij: 'alles was nieuw, onaangeraakt! (62). In een volgende fantasie kijkt hij 'bedeesd' (159) onder haar jurk, maar de fantasie stopt als zij de knoopjes van haar jurk heeft losgemaakt en hij haar huid ziet: 'weerloos wit als vruchtvlees' (159). In het vervolg van die fantasie ruikt hij onder haar jurk 'een pittige geur' (164). De enige interactie die daadwerkelijk tussen hen plaatsvindt in zijn dromen is dat zij hem laat drinken - aan haar borst, zo is de suggestie. Zij wordt daarmee een moederfiguur, en hij neemt de positie in van kind. De ver-

\footnotetext{
${ }^{18}$ Het graf van zijn moeder kan alleen een zuivere plaats zijn doordat Theo gedachten over wat daarbinnen gebeurt afweert, of doordat zij al zolang (tien jaar) dood is: tegenover de onzuiverheid van het rottende, in ontbinding verkerende lijk staat de zuiverheid van het harde, stabiele skelet, aldus Labrie $(2001,59)$.

${ }^{19}$ De naam Agnes is afgeleid van het Griekse hagnos, wat 'kuis' betekent.
} 
menging van het moederlijke en het maagdelijke heeft een religieuze ondertoon: Agnes wordt een beeld van de maagd Maria, en daarmee wordt Theo vanzelf gepositioneerd als de Zoon. Dat maakt niet alleen Agnes tot een aseksueel en heilig wezen, maar ook Theo. ${ }^{20}$

Theo's obsessie met zuiverheid uit zich ook in het enthousiasme waarmee hij thuis alles aan kant houdt en een wezel opzet (opdat die niet meer door bederf wordt aangetast), maar vooral in zijn 'broeiberg'. Dat is een hoop afval onder plastic, waarmee hij een soort alchemistisch experiment uitvoert: hij 'voert' de berg groenteafval, restjes bier en botten en wacht tot het rottingsproces iets zuivers zal voortbrengen, 'de stof van alle stoffen, de som van de eigenschappen, een chemisch wit' (60). Als hij Pieter erover vertelt, wordt hij helemaal lyrisch: 'Alles wordt ten slotte zuiver [...] het is het wit van alle stoffen, zo schoon...als je ernaar kijkt ben je al gewassen, zo schoon is het...maar je kunt het niet aanraken...' (123).

Theo's alchemistische logica over de broeiberg is dat hoe abjecter het ding is, hoe zuiverder het zal worden. Die logica past hij ook op zichzelf toe: hoe slechter hij nu is, des te beter zal hij worden. Hij is immers ook zelf onderdeel van een alchemistisch proces, namelijk de verbinding die hij probeert aan te gaan met Otto, de chemie tussen hen zogezegd. Theo's aanwezigheid in de villa betekent een vermenging van categorieën die wat de anderen betreft gescheiden hadden moeten blijven, waardoor hij de orde ondermijnt. Theo zelf hoopt op 'het wit van alle stoffen' in de broeiberg van de villa. Het vervagen van de gren-

\footnotetext{
${ }^{20}$ In Rosenbooms Gewassen vlees (1994), de roman die volgde op Vriend van verdienste, is ook zo'n obsessie met zuiverheid te vinden. Hoofdpersoon Willem Augusteijn vertoont opmerkelijke overeenkomsten met Theo Altink. Willem is net als Theo uit op innerlijke reiniging (en voert die zelfs letterlijk uit, via een klisteerspuit) en identificeert zich eveneens met een getemde vogel: een valk. Opvallend is ook de afwezige moeder in beide romans: Willems moeder stierf in het kraambed. Ze hebben bovendien vergelijkbare fantasieën over hun onbereikbare geliefde, die versmelt met het beeld van hun dode moeder. Bousset (1996) brengt Gewassen vlees in verband met het werk van De Sade, en schrijft over Willem: 'Enerzijds wil hij innerlijk schoon zijn, anderzijds houdt hij ervan ondergeschikte mensen en weerloze dieren met een pervers genoegen te vernederen en te pijnigen.' (Bousset 1996, 19). Theo vertoont ten opzichte van weerloze dieren eenzelfde sadisme als Willem. Hij sprenkelt gif in de wonden van een lammetje dat door de kraai wordt aangevallen: 'De volstrekte weerloosheid tegenover hem [van het lam, AA] bracht hem in een toestand van grote opwinding' (12). Later, in het torenkamertje, vangt hij een muis die hij aan Rokko aanbiedt. Aandachtig volgt hij de verrichtingen van de kraai bij het doden van de muis. Gewassen vlees is in veel opzichten een voortzetting en explicitering van ideeën over macht en seksualiteit die ook Vriend van verdienste structureren. Het grote verschil tussen beide romans ligt op het terrein van de seksualiteit. Terwijl de achttiende-eeuwse Willem Augusteijn zich uitleeft in seksuele perversiteiten, verliest Theo zijn (seksuele) onschuld niet.
} 
zen gaat onvermijdelijk gepaard met processen van abjectie, en de beschrijvingen daarvan krijgen in Vriend van verdienste ruim baan.

Als Theo in het verstikkend hete torenkamertje van de villa zit, waar hij ruim een maand verblijft, vervuilt hij in rap tempo. Hij krijgt een emmer, halfvol water, om zijn behoeften op te doen. Binnen een dag stinkt die emmer enorm, ondanks dat hij er parfum over uitsprenkelt en er een deken over hangt. Als hij de eerste nacht door dorst gekweld wordt, drinkt hij uit zijn emmer, wat minutieus wordt beschreven. Theo 'zuivert' eerst het water - hij zeeft zijn uitwerpselen uit de emmer en gooit ze de trap af: 'Telkens als hij de onvoelbare vlokken en klodders van zijn verweekte ontlasting boven het trappegat had afgeschud stak hij opnieuw zijn hand in het water' (163). Eerst doet hij nog een gebed, en dan staat hij op het punt om te drinken: 'Voor een moment was hij bedwelmd, toen wekte de zware zure stank van urine, ontlasting en parfum een onweerstaanbare gulzigheid in hem op' (163). Zodra hij het water drinkt krijgt hij een visioen, ontstaat er een 'helder schijnsel' in hem dat hem verblindt en doet sidderen: 'De duisternis scheurde open en uit het stralende licht kwam Agnes naar voren treden, zij naderde met in haar hand een volle peer...' (164).

Op het moment dat hij een van de meest abjecte dingen doet - drinken uit een emmer met zijn eigen uitwerpselen - krijgt hij een visioen van zuiverheid. Door het drinken te beschouwen als een rituele handeling - zijn volgende associatie is met een indiaan die 'de proef aflegt om man te worden' door een dag lang een slok water in zijn mond te bewaren - weet hij het abjecte te perverteren en op te vatten als iets zuiverends. Het religieuze ritueel maakt van het abjecte iets zuivers, al is het ritueel zelf ook al geperverteerd weet Theo, want hij heeft zichzelf aanbeden: 'Ik heb gebeden voor mijn eigen spiegelbeeld, en er was licht' (165). Theo is in staat om zijn abjectie als noodzakelijk of zelfs wenselijk te ervaren, dankzij zijn alchemistische logica. Hij vergelijkt zijn eigen verloedering dan ook met de broeiberg: 'De hitte, de stank en de rottenis om mij heen [...] dat is allemaal precies hetzelfde als in de broeiberg. [...] "Ik word voos en verslijm", mompelde hij, "maar als het tenslotte niet erger meer kan worden, dan zal ik witter zijn dan sneeuw! Ik word een nieuwe jongen...de ander!"” (234). Theo's streven naar zuiverheid heeft een morele en een religieuze dimensie: hij wil onbezoedeld zijn van zonden. Die staat heeft zijn moeder - in de hemel - al bereikt, maar Theo hoopt die door een wedergeboorte te bereiken, door 'een nieuwe jongen te worden'.

Niet alleen Theo's emmer, maar ook zijn broeiberg biedt een tamelijk weerzinwekkende aanblik, althans door de ogen van Freddie die het zeil van de berg optilt, op zoek naar de gestolen sextant: 
De broeiberg met de dunne, grauwe korst leek wel wat op een koud geworden bord aardappelen waarover de gestolde jus een glazig, mat vlies heeft gelegd, in de kleur van oud vet. Kokhalzend stak hij [Freddie] de spade in de drabbige derrie. Na enig wroeten was de gebarsten korst geheel verdwenen en glinsterde de rottenis hem onbewimpeld tegen. Wanneer hij de schop in de weke brij stak ontsnapten er liederlijke darmgeluiden. De stank werd zo zwaar dat het hem verbaasde dat die onzichtbaar bleef en niet als een gele walm aanschouwelijk werd. Hij wrikte de steel wat opzij en keek in de schacht. Dikke grondtorren kropen tevoorschijn en tuimelden in de diepte waar het zwarte sap reeds samenvloeide. Van de olie en het kwik waarover Theo hem in de allermeeslependste bewoordingen verteld had viel nog niets te zien. (180)

In Freddies fantasie lopen even later de krioelende torren uit de broeiberg en Theo's gezicht in elkaar over, en zegt hij tegen Theo over de broeiberg 'Lijkt goed...mooi portret, bedoel ik' (187). Dat is een veelzeggende vermenging van categorieën: niet alleen Theo's attributen - de emmer, de broeiberg - zijn abjecte dingen, Theo zelf is een ab-ject, iemand die geen vastomlijnde identiteit meer heeft. Op den duur steekt hij alles aan wat in zijn buurt is: 'Dertig dagen zat hij nu hier, en dertig dagen dampte zijn ontlasting door de deken uit de emmer. Het was een oude, opgehoopte stank die, gemengd met zijn zure lichaamsgeur, alles deed verrotten wat ermee in aanraking kwam' (198).

Theo is, zeker in het begin, de belangrijkste focalisator in de roman, waardoor de lezer/es volop deel heeft aan zijn rijke verbeelding. Als hij lang in het kamertje zit komt de focalisatie echter ook bij anderen te liggen, bij Freddie en bij Otto. De verschuivende focalisatie lees ik als een teken van Theo's voortschrijdende 'abjectie'; steeds minder is hij in staat om als subject de gebeurtenissen waar te nemen. Als Theo langzamerhand in een levende dode verandert, en het verschil tussen dag en nacht of tussen waken en slapen nauwelijks meer waar kan nemen, wordt hij aangeduid als 'de jongen die op de matras lag' (236); een wezen zonder naam, een uitgestotene.

Volgens Kristeva bevindt het abjecte zich buiten de relatie subject-object. Terwijl er tussen subject en object een relatie van verlangen bestaat, bewust of onbewust, is er tussen subject en abject een relatie van uitsluiting: 'Some lives [are] not sustained by desire, as desire is always for objects. Such lives are based on exclusion.' (Kristeva 1982, 6). Deze relatie van uitsluiting is inderdaad bepalend voor de verhoudingen in Vriend van verdienste, vooral tussen Otto en Theo. Theo wordt gedreven door het verlangen om Otto voor zich te winnen als vriend, maar hij wordt uitgestoten. Hij beseft niet dat hij in Otto's ogen 
helemaal geen mogelijke vriend is. ${ }^{21}$ Otto zelf wordt, althans in Theo's waarneming, niet gedreven door enige verlangens:

Hij was nog groter dan in zijn voorstellingen, een traag bewegend, onaandoenlijk fabeldier. Hoewel de inspanning van de klim hem sneller deed ademen en zijn gezicht glansde van het zweet maakte hij in het geheel geen vermoeide indruk. Als onveranderlijk wezen scheen hij wel nooit in een bepaalde toestand te kunnen verkeren: als hij at of dronk hield dat in genen dele verband met een gevoelde honger of dorst; wanneer hij hijgde was dat louter een bepaalde manier van ademhalen die allerminst veroorzaakt werd door de gesteldheid van zijn lichaam; en zelfs wanneer hij sprak scheen daar geen enkele wil, verlangen of noodzaak zich te communiceren aan ten grondslag te liggen - in zijn fenomenale hoedanigheid leek hij volkomen ontledigd van innerlijke behoeften, drijfveren of ook fysieke processen: hij was zuivere verschijning. (149-150)

Otto is een 'zuivere verschijning', een wezen zonder verlangens of behoeften. Theo realiseert zich niet dat dat gebrek aan verlangen ook - of vooral - hemzelf betreft. Terwijl Theo de verhouding tussen Otto en hem denkt als een subjectobject relatie, waarin hij zelf het object is, de toekomstige vriend, is hij in Otto's ogen eerder abject, iets abjects. Voor Otto is Theo iets dat buitengesloten moet worden, en dat hij bij voorkeur negeert. Afgezien van een bezoekje aan Theo aan het begin van diens verblijf, komt Otto dan ook niet meer bij hem kijken. Pas na dertig dagen komt Otto weer eens langs, en zegt dan tegen Theo: 'om eerlijk te zijn, ik was je gewoon vergeten' (201).

Hoewel het abjecte dus buiten de relatie subject-object ligt, heeft het wel invloed op het subject, volgens Kristeva: 'It [the abject] lies outside, beyond the set, and does not seem to agree to the latter's [the master's] rules of the game. And yet, from its place of banishment, the abject does not cease challenging its master' (Kristeva 1982, 2). Het abjecte dwingt zijn 'master' om steeds opnieuw de grenzen van diens universum af te bakenen, maar deze grenzen zijn nooit definitief, omdat ze bepaald worden door dat wat abject is, aldus Kristeva. Theo probeert voortdurend Otto's ongenaakbare verschijning, de 'onvergelijkbare gestalte' (199), aan te tasten. En dat lukt hem. Otto's soliditeit wordt ondermijnd door Theo's aanwezigheid. Zijn onverschilligheid en kalmte maken uit-

\footnotetext{
${ }^{21}$ Iets vergelijkbaars gebeurt als Theo Rokko aan het temmen is. Hij voelt zich buitengesloten en vreest dat hij door de vogel niet als vijand erkend wordt: 'Maar als hij niet eens als vijand werd gezien, hoe kon hij dan winnen?' (102). Met andere woorden: als er geen subject-object relatie is, valt er niet te strijden en dus ook niet te winnen.
} 
eindelijk plaats voor agitatie en geweld. Het 'onaandoenlijk fabeldier' krijgt astmatische aanvallen en valt ten slotte van de trap. Ook als de broers Theo na een aantal weken willen vergiftigen heeft Otto een moment van zwakheid, en krijgt hij opnieuw een astmatische aanval - 'ik kan het niet' (246) weet hij nog net uit te brengen. Abjectie leidt tot identiteitsverlies. Dat geldt voor Otto, die er niet in slaagt om Theo werkelijk buiten te sluiten. Het geldt ook voor Pieter, maar op een andere manier. Hij doet geen pogingen om Theo met geweld buiten te sluiten, maar verzorgt hem een maandlang in het kamertje. Toch verliest Pieter uiteindelijk zijn identiteit, in de meest radicale zin: niet Theo zal sterven, maar hij.

Literatuurwetenschappers Avril Horner en Sue Zlosnik (2001) hebben Kristeva's concept van het abjecte in verband gebracht met het gotieke. Volgens hen stelt het gotieke ons in staat om vast te stellen hoe constructies van het 'Andere' gebaseerd zijn op gedeelde culturele waarden:

you may know a culture by what it abjects, or "throws off". [...] Abjection within the gothic text can thus be seen to signify both fear concerning the breakdown of culturally constructed boundaries of identity at a particular historical moment and an attempt to shore them up. (Horner \& Zlosnik 2001, 83)

Theo wordt uitgestoten als iets abjects, omdat hij de gevestigde orde bedreigt de orde waarin de (lagere) klassen hun plaats moeten kennen. Theo is misplaatst in de villa en daarom abject. Maar hier werkt een paradox: juist door zijn positie van uitgestotene kan Theo de orde uitdagen. Met zijn voortschrijdende abjectie wordt de bedreiging die van hem uitgaat eigenlijk alleen maar groter. Het is een spiraal waaruit deze jongens alleen door extreem geweld kunnen ontsnappen.

\section{JONGENS ONDER ELKAAR}

Als Theo in het torenkamertje trekt verandert hij langzaam in iets abjects. Dat is ook het moment in de roman waarop vrouwen grotendeels uit het zicht verdwijnen en de jongens uitsluitend nog met elkaar bezig zijn, op een manier die met steeds meer geweld gepaard gaat. Eve Sedgwick (1985) stelt dat dat patroon kenmerkend is voor de gotieke roman. $\mathrm{Zij}$ verbindt de veranderende relaties tussen mannen - door de afwezigheid van vrouwen - met de opkomst van een bepaald type gothic novel (paranoid gothic) en het ontstaan van een moderne homoseksuele identiteit. 
Sedgwick schetst aan de hand van gedetailleerde analyses van Engelse literaire werken hoe tussen ca. 1750-1850 relaties tussen mannen van karakter veranderen. Onder 'relaties' verstaat ze het hele spectrum van niet-seksuele banden tussen mannen (vriendschap, rivaliteit, mentorschap) tot seksuele relaties (uitmondend in moderne opvattingen van homoseksualiteit), wat ze aanduidt als het continuüm van 'male homosocial desire'. In navolging van de structuralisten René Girard en Claude Lévi-Strauss beschrijft Sedgwick hoe vrouwen als ruilmiddel de band tussen mannen bevestigen. Het maakt niet veel uit of dat banden van rivaliteit zijn, of van affectie, aldus Sedgwick. Die zijn qua intensiteit vaak even sterk. In Vriend van verdienste zijn Agnes, de klasgenote van Pieter en Freddie, en Dorien, de werkster, zulke 'ruilmiddelen'. Op de avond van het feestje in de villa staat Otto eerst met Agnes te zoenen, dan laat ze Pieter op haar vinger zuigen. Als Theo haar ten slotte naar huis brengt, krijgt hij van haar zijn eerste zoen. De jongens geven haar dus bijna letterlijk aan elkaar door, ze is beschikbaar voor iedereen en dat smeedt hen samen. Otto bevestigt zijn band met Theo via Dorien.

In de gothic novel worden vanaf eind achttiende eeuw homosociale banden tussen mannen op een nieuwe manier verbeeld, aldus Sedgwick. Daar kristalliseert een nieuwe, moderne vorm van homofobie zich uit, die het hele spectrum van mannelijke homosociale relaties reguleert:

In the English Gothic novel, the possibility - the attraction, the danger - of simply dropping the female middle term becomes an explicit, indeed an obsessional literary subject. With it comes a much more tightly organized, openly proscriptive approach to sexuality and homosocial bonding (Sedgwick 1985, 82)

Vanaf het moment dat een homoseksuele subcultuur en identiteit denkbaar wordt, worden alle verhoudingen tussen mannen (ook, of juist, de nietseksuele) potentieel gevaarlijk of verdacht: ze zóuden immers als homoseksueel gezien kunnen worden. ${ }^{22}$ Vallen vrouwen ('the female middle term') weg als

\footnotetext{
${ }^{22}$ Homoseksualiteit als identiteit komt in de plaats van homoseksualiteit als daad. Sedgwick dateert het ontstaan van een (Britse) homoseksuele subcultuur in de achttiende eeuw. Theo van der Meer (1995) beschrijft een vergelijkbare ontwikkeling in Nederland. De homoseksuele identiteit werd niet pas 'uitgedokterd' in de negentiende eeuw; al in de achttiende eeuw en eind zeventiende eeuw werd homoseksualiteit in termen van verlangens en gedrag gedefinieerd, zij het (nog) niet door wetenschappers. Ook in Nederland kan eind $17^{\mathrm{e}} / 18^{\mathrm{e}}$ eeuw al gesproken worden van een homoseksuele subcultuur; in andere delen van Europa was die er zelfs al eerder, aldus Van der Meer.
} 
bindmiddel tussen mannen, dan moet de heteroseksuele orde op een andere manier gewaarborgd worden, met duidelijke ge- en verboden. Dat gebeurt volgens Sedgwick via het mechanisme van paranoia: achtervolgingswaan. De gothic novels die ze aanhaalt worden gekenmerkt door plots waarin twee mannen elkaar achtervolgen (zoals in de slotscène van Frankenstein), waar een man onder de invloed staat van een andere man (zoals in Maturins Melmoth the Wanderer), of waar verdubbelingen aan de orde zijn (James Hogg, Private Memoirs and Confessions of a Justified Sinner). Door sommigen zijn die motieven gelezen als vroege verbeeldingen van mannelijke homoseksualiteit ${ }^{23}$, maar volgens Sedgwick is er iets anders aan de hand.

$\mathrm{Zij}$ leest deze gotieke romans als de eerste waarin een moderne homosexual panic vorm krijgt; het verbod op homoseksualiteit dat alle 'normale' verhoudingen tussen (heteroseksuele) mannen reguleert: 'the paranoid Gothic is specifically not about homosexuals or the homosexual; instead, heterosexuality is by definition its subject' (116). De stelling dat gotieke romans met een plot van 'mannen onder elkaar' eerder over heteroseksualiteit dan over homoseksualiteit gaan is prikkelend. Hoewel er inmiddels veel veranderd is in de uitingsvormen van homoseksuele identiteit en subcultuur, is het taboe op homoseksualiteit lang niet overal verdwenen. Voor mij is het gedachtegoed van Sedgwick aanleiding om te onderzoeken wat de manifestatie van het gotieke in een setting van jongens-onder-elkaar teweeg brengt in Vriend van verdienste. Welke effecten sorteert het gotieke in deze laattwintigste-eeuwse roman? Wordt paranoia in stelling gebracht om iets over homofobie c.q. de heteroseksuele orde te zeggen?

In Vriend van verdienste verdwijnen vrouwen in de loop van het verhaal als bemiddelende factor. De eerste avond in de villa is Agnes wel aanwezig, en wordt ze door de jongens aan elkaar doorgegeven; maar vanaf het moment dat Theo in de torenkamer zit, speelt ze nauwelijks nog een rol. Andere vrouwen verdwijnen vrijwel uit beeld, zoals huishoudster Dorien en de minnares van vader Van Hal. Theo's moeder is al dood, die van Pieter en Otto min of meer gek. In de afwezigheid van vrouwen worden de relaties tussen de jongens steeds gewelddadiger en krijgen inderdaad paranoïde trekjes.

Eerst probeert Theo zijn onderduik in de villa te verzekeren door Otto onder druk te zetten. Hij wil Otto aan zich binden door hem ervan te overtuigen dat die hem iets verschuldigd is. ${ }^{24}$ Theo formuleert die schuld eerst in economische termen, als een ruil - voor wat hoort wat. De dienst die Theo aan Otto heeft bewezen door de sextant te stelen moet door Otto beantwoord worden

\footnotetext{
${ }^{23}$ Zie bijvoorbeeld Haggerty $(1989,2006)$ en Veeder (1986), over homo-erotiek in Frankenstein.

${ }^{24} \mathrm{Zie}$ voor uiteenlopende verbeeldingen van het schuldmotief in de literatuur Atwood (2008).
} 
met vriendschap, of op zijn minst met een verblijf in de villa. Theo dreigt aan de politie te onthullen dat Otto verantwoordelijk is voor de diefstal van de sextant, als hij niet mag blijven. Als Otto daar niet van onder de indruk blijkt gooit Theo het over een andere boeg: hij wijst Otto op het feit dat hij hem, 'een minderjarige jongen uit een ongelukkig gezin' (155) heeft aangezet tot diefstal, 'een jongen zonder moeder, die gemakkelijk te beïnvloeden is' (155). Theo maakt dus van de economische schuld een morele schuld: door Otto's slechte invloed is hij slecht geworden. Voor die gewetensmanipulaties van Theo blijkt Otto wel gevoelig. Hij probeert de door Theo opgelegde band meteen met geweld te verbreken: de eerste avond al slaat hij Theo onderuit. Een dag later slaat hij op het torenkamertje een glasplaat aan diggelen. Het lukt Theo om de schijnbaar onaantastbare Otto zo onder druk te zetten dat deze fysiek aangedaan is.

Theo eist Freddies steun voor zijn onderduikactie met hetzelfde argument waarmee hij Otto onder druk zet: dat hij tot de diefstal is aangezet omdat hij onder Freddies slechte invloed staat: '[M]isschien denken ze wel dat ik word opgestookt door een oudere jongen, onder wiens invloed ik sta...[...] ze weten ook dat ik geen moeder meer heb' (144). Ook Freddie reageert met geweld: eerst gaat hij schrijlings op Theo's borst zitten en krabt zijn polsen open, vervolgens sleept hij Theo ruggelings aan zijn benen door het kamertje, niet wetend dat de vloer vol glasscherven ligt van Otto's eerdere uitbarsting. Theo's rug verandert zo in een bloederige massa; zodra Freddie begrijpt wat hij heeft aangericht ontvlucht hij het kamertje.

De geweldsuitbarstingen van Otto en Freddie tonen hun machteloosheid, hun gebrek aan controle over de jongen die zich paradoxaal genoeg totaal aan hen onderworpen heeft. Ze vormen de voorbode van paranoïde angsten, die niet alleen vat krijgen op Otto en Freddie, maar ook op Theo zelf. Otto denkt dat hij Theo gezien heeft in de tuin, om Agnes en hem te bespieden, en komt 'geheel overstuur' (211) het kamertje binnenvallen: 'Je zat tussen de struiken...Ik zag het wel, je bespiedde Agnes en mij...Ben jij soms helemaal gek geworden?' (211-212). Pieter probeert hem ervan te overtuigen dat dat onmogelijk is, omdat hijzelf op dat moment bij Theo was, maar dat werkt averechts. Otto bijt hem toe ' het is maar net goed gegaan!' (212) en doet alsnog Theo's kamertje op slot, 'geheel buiten zinnen nu' (212). Theo is, na zijn eerste schrik over Otto's verlies van zinnen, tevreden over het effect dat hij heeft bewerkstelligd - helemaal als Rokko hem de sleutels van zijn kamertje heeft bezorgd. De paranoia blijkt echter besmettelijk. Ook Theo zelf krijgt er last van, wat hem ertoe drijft om zelf de deur van zijn kamer op slot te houden: 'Aangeraakt door een ijselijke kou luisterde hij naar de voetstappen die hem in het hoofd bonsden 
[...] Was het Pieter die hem volgde? Hij wist nu zeker dat hij beslopen werd [...] Had hij de deur wel op slot gedaan?' (220).

Ook Freddie heeft een waanvoorstelling. Als hij een dag nadat hij Theo door het glas heeft gesleept onaangekondigd het torenkamertje bezoekt, hoort hij gegrom en gehijg uit het kamertje komen. Op weg naar boven stinkt het: 'De stank nam met elke trede toe en deed hem slikken en snuiven: hoe moest het daarboven wel niet zijn, ad fontes? Kleine, bruine klodders smeer kleefden aan de muur.' (184-185). 'Ad fontes' verwijst allereerst naar het kamertje, maar ook - letterlijk - naar de bron van de geur. De muur langs de wenteltrap, besmeerd met Theo's uitwerpselen, roept bij Freddie onwillekeurig associaties op met de fysieke bron van die uitwerpselen, oftewel met Theo's anus. Dat zou geïnterpreteerd kunnen worden als een onbewust verband tussen het abjecte en homoseksualiteit. Dat verband lijkt in Freddies verbeelding expliciet te worden als hij, bovengekomen, Pieter schrijlings op Theo ziet zitten:

Het tafereel in het kamertje deed hem duizelen. Theo lag, schijnbaar geheel naakt en glanzend van het zweet, op zijn buik op de matras, met zijn hoofd afgedraaid zodat hij alleen zijn donkere krullen kon zien. Pieter zat schrijlings op zijn bovenbenen, diep voorover gebogen, alsof hij een snelle brommer bereed. Hij scheen zo hard in Theo's rug te knijpen dat deze met zijn handen over de grond krabde en soms ook in de rand van de matras beet. Zodra hij begreep wat er werkelijk gaande was loste zijn pornografische visioen op en kwam hij ook zijn korte maar hevige schoktoestand te boven (185)

Freddie heeft een 'pornografisch visioen'. Het feit dat hij dat kan hebben, geeft aan dat het niet ondenkbaar voor hem is dat er een homoseksueel contact tussen de twee jongens is, hoezeer hij er ook door geschokt is. De grens tussen vriendschap en seksualiteit begint dus voor Freddie te vervagen. De betrokkenen zelf, Theo en Pieter lijken zich van geen homoseksuele betekenis bewust. Pieter is bezig met een pincet de glasscherfjes uit Theo's rug te halen en vertelt ondertussen over de naamgeving van de villa.

Sedgwick ziet in de gothic novel rond 1800 het ontstaan van een 'homosexual panic' die een nieuwe betekenis inluidt van verhoudingen tussen (heteroseksuele) mannen. Vanaf die tijd worden de verhoudingen in het mannelijke universum mede bepaald door (de angst voor) een seksuele ondertoon. Die angst is voelbaar in Freddies reactie. Er is nog zo'n scène die associaties met homoseksualiteit oproept, eerder in de roman. Op de avond dat Theo zijn toevlucht zoekt in de villa kruipt hij bij Pieter in bed bij gebrek aan een andere slaapplaats. Ze 
bekijken elkaars lichaam onder het laken en constateren dat ze erg op elkaar lijken. Beiden vinden dat de ander lekker ruikt, en Pieter stelt voor om te gaan liggen als 'lepeltjes in een doosje' (123). Ook hier lijken Theo en Pieter zich van geen erotische betekenis bewust. Deze onschuld wordt verstoord door Otto, die hartgrondig vloekt als hij Pieter en Theo samen aantreft: 'hun hoofden gevangen in de kring van licht' (125), en Theo naar het torenkamertje jaagt. Doordat Theo focaliseert valt niet uit te maken of Otto vloekt omdat hij de twee verdenkt van homoseksualiteit, of omdat hij ziet dat Theo naar de villa is gekomen. Theo schaamt zich diep: niet omdat hij met Pieter in een bed is ontdekt, maar omdat hij alleen een onderbroek aanhad terwijl hij voor Otto uit de trap opging: 'een onoverkomelijke schande: slechts gekleed in zijn onderbroek' (128). Volledig gekleed zijn is belangrijker voor zijn gevoel van eigenwaarde dan met een andere jongen betrapt worden in bed. Theo's seksuele onschuld blijft de hele roman nadrukkelijk intact. Zijn seksuele fantasieën over Agnes blijven kuis, en ook in een passage die als een bloemrijke beschrijving van een natte droom gelezen kan worden blijft hij onbewust:

Kwikvlugge herinneringen warrelden hem door het hoofd, maar schuw verscholen ze zich voor zijn aandacht zodat hij ze niet denken kon, alleen maar voelen - veilig voor zijn ontvouwende verstand bleven ze gesloten als bloemen bij nacht. Het vluchtige getintel ontledigde hem en zich overgevend aan het gevoel van zwellen en zweven gleed hij terug in de slaap. (129)

In de aangehaalde voorbeelden lijkt het uiteindelijk niet om seks te draaien. De vier jongens zijn onderling verwikkeld in een strijd om de macht, en daarin staat behalve klasse en leeftijd vooral mannelijkheid op het spel. Door die strijd zijn ze zo intens op elkaar betrokken dat ook voor henzelf de grenzen niet altijd duidelijk meer zijn tussen 'being a man's man' (homosociaal) en 'being interested in men' (homoseksueel), zoals Sedgwick het subtiele verschil uitdrukt. Ik lees de verwijzingen naar homoseksualiteit in de roman (de scène met de spuitende champagnefles waar Theo zich tegen Pieter aandrukt liet ik nog buiten beschouwing) dan ook meer in het kader van een strijd tussen jongemannen om de macht die hier op gotieke wijze wordt uitgevochten, dan rond (homo)seksualiteit. Zoals Ernst van Alphen (1994) het verwoordt:

De intensiteit van de betrokkenheid op andere mannen die de homosociale strijd met zich meebrengt, is juist voor homosociale mannen zo bedreigend omdat deze uiteindelijk verward raakt met homoseksueel verlangen dat juist via homofobie buitengesloten moet worden. (Van Alphen 1994, 352). 
Diezelfde verwarring tussen intense betrokkenheid via rivaliteit en homoseksueel verlangen speelt in Vriend van verdienste. Van Alphen beschrijft hoe de rivaliteit tussen twee mannen in The Comfort of Strangers van Ian McEwan onvermijdelijk leidt tot ontmanning van de een door de ander, want: 'De mannelijke identiteit wordt gemeten aan de positie van andere mannen die zich hoger of lager op de schaal bevinden' (351). ${ }^{25}$ Het draait uiteindelijk om macht en om mannelijkheid.

\section{MANNELIJK MASOCHISME}

Primitief geweld is wat Otto en Freddie betreft de enige mogelijke reactie op de chaos die dreigt te ontstaan door Theo's uitdaging van de orde. Maar het geweld heeft geen vat op Theo, omdat die niets liever wil dan zich onderwerpen: 'Tegenover de rijzige kolos was hij zo volkomen weerloos, voelde hij, dat juist daarin zijn veiligheid besloten lag: Otto zou zich nooit aan hem kunnen vergrijpen, zeker niet als hij ruggelings voor zijn voeten lag - met zijn lichaam had hij zich al lang aan hem overgegeven' (156). ${ }^{26}$ Het geweld bevestigt hem juist in zijn positie en maakt hem in zekere zin nog subversiever, nog bedreigender. Zijn masochisme is een vorm van wat Kaja Silverman (1992) 'deviant masculinities' noemt: marginale, niet-dominante vormen van mannelijkheid. Theo is zo'n soort man.

Hij maakt een spektakel van zijn gemartelde lichaam en gebruikt zo zijn niet-dominante positie om macht uit te oefenen. ${ }^{27} \mathrm{Hij}$ probeert Otto aan zich binden door zich te onderwerpen en zijn wonden te laten zien: zijn bebloede handen, zijn kapotte rug. Via fysieke onderwerping probeert hij de band met Otto tot stand te brengen, met zijn lichaam als levend aas. ${ }^{28}$ De reactie van Otto

\footnotetext{
${ }^{25}$ Mijns inziens is het niet toevallig dat Van Alphen in zijn analyse refereert aan relevante passages uit Bram Stokers klassieke gothic novel Dracula (1897). Hoewel hij het gotieke interpretatiekader niet expliciet inzet bij zijn lezing van McEwan, valt te verdedigen dat de band tussen mannen ook in die roman op gotieke manier gestalte krijgt.

${ }^{26}$ Opnieuw is er een overeenkomst met de houding van Theo ten opzichte van Rokko. 'Vriendschap voor vrijheid, was dat teveel gevraagd?' (20) denkt Theo als hij Rokko aan het temmen is. Hij heeft de kraai zijn vrijheid ontnomen, maar 'biedt' - volgens zijn eigen logica - daarvoor in de plaats zijn vriendschap.

${ }^{27}$ Over gotieke lichamen schrijft Bruhm (1994).

${ }^{28}$ Ook hier gaat de vergelijking met Rokko op - die wordt door Theo met levend aas gevangen 'giftig aas, maar toch nog levend!' (17). Later krijgt Rokko opnieuw levend aas, een muis, vlak voordat hij wordt doodgedrukt door Otto.
} 
is niet empathisch, hij identificeert zich niet met Theo. ${ }^{29} \mathrm{Hij}$ reageert met nieuw geweld, op het moment dat Theo zich het meest onderwerpt, als hij zegt 'je moet me wegdoen Otto!' (240).

Freddie verzoent zich in eerste instantie wel met Theo en ze omhelzen elkaar: 'De roerloze omhelzing leek wel net zo lang te duren als de zaligheid zelf (189) (focalisatie bij Freddie). Maar als Theo de omhelzing verbreekt, ervaart Freddie dat alsof een pleister van hem afgetrokken wordt: 'het was of [...] hij zijn ontroering nu droeg als een onbedekte, open wond' (189). Terwijl Freddie de schuld van Theo's bebloede rug probeert te verzoenen, wordt zijn eigen ontroering een 'open wond'. Als Theo hem opnieuw, beschuldigend, de rug toekeert - waarmee die zich de wond als het ware weer toeëigent - maakt Freddies kwetsbaarheid plaats voor woede: hij slaat Theo opnieuw in elkaar.

Theo's verlangen om gestraft te worden heeft seksuele connotaties. Aan mannelijk masochisme ligt volgens Silverman altijd een 'intrinsically homosexual beating fantasy' ten grondslag (Silverman 1992, 9)..$^{30}$ Theo heeft al vroeg in de roman een SM-achtige fantasie, met homo-erotische ondertoon, waarin hij wordt opgepakt door de politie: 'Dankbaar sloeg hij zijn ogen op, hij keek omhoog langs de laarzen, de galonbroek, de koppelriem en hoger nog. [...] Hij krabbelde wat overeind en nog gezeten op zijn knieën greep hij naar de handboei die de agent glimlachend liet bungelen aan de ketting' (72).

Masochisme kan per definitie alleen bestaan dankzij een machtsverschil. Macht wordt in het begin van de roman nog in economische termen gedefinieerd, zoals ik liet zien in het stuk over vriendschap en klasse, maar krijgt in de loop van het verhaal een morele invulling: schuld aan de beïnvloeding van Theo en schuld aan zijn marteling. Theo's (economische) dienstbaarheid maakt plaats voor zijn vrijwillige fysieke onderwerping en krijgt dan een masochistisch karakter. Deze verschuiving van een economische naar een fysieke macht valt samen met de verdwijning van vrouwen en een toename van de verwijzingen naar homoseksualiteit. Vriend van verdienste laat zien hoe dicht homosociaal geweld en verlangen bij elkaar liggen. Mannelijk masochisme is een bedreiging voor de

\footnotetext{
${ }^{29}$ Bruhm onderscheidt drie reacties op pijn: een identificerende reactie (ik weet hoe je je voelt); een toe-eigening van het lijden (dit doet mij meer pijn dan jou); en pijn als bron van zelfkennis (I hurt therefore I am). Bruhm (1994), 146-147.

${ }^{30}$ Niet voor niets geldt de Heilige Sebastiaan, zinnebeeld van de masochist die altijd vastgebonden aan een boom wordt afgebeeld met een door pijlen doorboord lichaam, als schutspatroon van de homoseksuelen, aldus Silverman. Vergelijk ook Dyer (1983), die de martelaar een homoseksueel stereotype noemt: 'Not simply despite but because of the history of Christian persecution of gays, the Christian tradition yields an iconography of punishment as pleasure, suffering as beauty, that has been particularly fruitful in the development of gay images' (Dyer 1983, 44). Met dank aan Roel van den Oever.
} 
orde, terwijl het paradoxaal genoeg alleen kan bestaan bij de gratie van het machtsverschil dat het bedreigt.

Pieter is als enige niet betrokken bij het fysieke geweld tegen Theo, en lijkt ook niet vatbaar voor paranoia. Is hij niet verwikkeld in een strijd om de macht? Hoeft hij zijn mannelijkheid niet te bewijzen door Theo zijn plaats te wijzen? Wordt hij misschien gedreven door iets anders? Doordat Pieter nergens focaliseert blijven zijn motieven voor de lezer onduidelijk. Pieter fungeert voornamelijk als Theo's spiegelbeeld, diens 'zuivere' zelf. Terwijl Theo Otto wil hebben, wil hij Pieter zijn. Die wens komt tot uitdrukking via het voortdurend in de spiegel kijken. Theo is van meet af aan geobsedeerd door zijn eigen spiegelbeeld; als Narcissus kijkt hij in de vijver van het park: 'Eerst toen hij zich over het stille water boog kalmeerde hij wat, want zijn spiegelbeeld beviel hem uitermate' (7). Ook zijn eigen spiegelbeeld in het busraam is 'een weldadige bekoring' (74). Op zijn torenkamer krijgt hij een theekastje, dat van binnen met spiegels is bekleed. Het kastje heeft voor hem een sacrale functie. Theo noemt het zijn 'heiligheidje' (142) en 'wijdt' het zelfs door het met parfum te besprenkelen en te voorzien van relikwieën. Hij knielt ervoor en doet een gebed, maar op dit altaar aanbidt hij vooral zijn eigen spiegelbeeld: 'Nog nooit eerder had zijn spiegelbeeld zo'n weldaad in hem uitgericht' (141) denkt hij als hij in het kastje kijkt; en later wordt hij opnieuw gesterkt door 'de bekoring van zijn spiegelbeeld' (193).

Theo gebruikt het theekastje om zijn eigen positie te bepalen, om bevestiging te zoeken, en daarmee fungeert het in feite als een sextant. Een sextant is een navigatie-instrument waarmee men via twee spiegels zijn positie kan bepalen. ${ }^{31}$ Via de twee haaks op elkaar staande spiegels in het kastje kan Theo de 'andere' kant van zijn gezicht zien 'het gezicht dat niet terugkeek, de ander' (142). Theo identificeert deze 'ander' met Pieter, op wie hij immers uiterlijk lijkt: 'het was iemand anders, iemand die voor zich uitkeek zonder te beseffen dat hij bespied werd...Pieter!' (141). Hier zegt Theo met zoveel woorden dat Pieter niet paranoïde is, want hij beseft niet dat hij wordt bespied. Theo hoopt dat hij Pieter kan worden. Hij fluistert tegen het beeld in de spiegel: 'Kun jij niet naar mij toekomen, om [...] als ik in gevaar ben, ook mijn plaats even in te nemen? We lijken precies op elkaar...Als ik kon zou ik jou willen zijn, maar zul jij dan ook mij worden?' (142). Theo wil zichzelf niet zijn, hij wil ontstijgen aan zichzelf; dan zal hij zuiver worden, 'een nieuwe jongen'.

\footnotetext{
${ }^{31}$ Met een sextant wordt de verticale hoek tussen horizon en een hemellichaam (de zon of de poolster) gemeten, om de breedtegraad te bepalen. Een punt wordt zowel rechtstreeks als via een stelsel van twee spiegels waargenomen.
} 
Theo en Pieter vormen dus een verdubbeld personage, een gotiek mannenkoppel zoals Sedgwick dat schetste, met het verschil dat zij niet door paranoia worden gedreven (Theo is alleen paranoïde ten opzichte van Otto) - kennelijk heeft het mechanisme van homofobie op hen geen vat. Vlak voordat Theo het kamertje zal verlaten drukt Pieter hem nog op het hart: 'Vrienden maken, dat is het belangrijkste, je moet je aansluiten bij jongens die net zo zijn als jij...Denk aan zulke dingen, en niet aan die malle mijmerijen die je voor de spiegel hebt gehad!' (256). Pieter kende dus Theo's fantasieën in het theekastje, maar voelde zich daardoor kennelijk niet bedreigd. Het is ironisch dat hij Theo maant om vrienden te zoeken - dat was immers steeds Theo's voornaamste streven; maar Pieter impliceert dat hij het bij de verkeerde gezocht heeft. Toch is 'jongens die net zo zijn' in dit verband een dubbelzinnige opmerking: het kan gaan over jongens die van dezelfde klasse, of jongens die anderszins op hem lijken - maar dat gold juist voor Pieter, die was 'net als' Theo: hij leek sprekend op hem. En ten slotte kan de uitdrukking jongens die 'net zo' zijn gelezen worden als een mogelijke verwijzing naar homoseksualiteit, en ook dat zou naar Pieter zelf kunnen verwijzen. ${ }^{32}$

Voor de lezers uit 1985, net als voor de lezer van nu, zijn de homoseksuele bijbetekenissen van de hier besproken scènes - Freddies visioen, Pieter en Theo samen in bed - haast onontkoombaar. Van de recensenten was Hans Warren, zelf homoseksueel, de enige die expliciet melding maakte van een 'homoseksuele ondertoon' in de roman (Warren 1986), al las Thomas Verbogt die waarschijnlijk ook. ${ }^{33}$ Verbogt vond namelijk het benoemen van het 'pornografische visioen' overbodig: 'wat al duidelijk is, hoeft niet nogmaals duidelijk gemaakt te worden.' (Verbogt 1986). De roman geeft hooguit door het feit dat expliciete

\footnotetext{
32 'Ook zo' was lang een codewoord onder homoseksuelen. Zie over verhullend taalgebruik met betrekking tot homoseksualiteit Hans Warmerdam en Pieter Koenders (1987) p. 134-137.

${ }^{33}$ De vraag naar mogelijke homoseksuele motieven voor de moord hielden de gemoederen ook bezig ten tijde van de Baarnse moordzaak zelf. Zie Beerman (1963) voor een compilatie van krantenverslagen. Fabricius gaf in zijn romanversie Jongensspel de oudste zoon twijfels over zijn geaardheid mee: 'Is het onnatuurlijk, is het verdacht dat ik nog nooit iets met een meisje heb geprobeerd? [...] Ik kan me eigenlijk niets voorstellen bij het woord "homo". Als ik er een ben, heb ik er zelf nog nooit iets van gemerkt' (Fabricius 1963, 103). De jurist E. Brongersma reageerde met een uitvoerig verslag van de rechtzaken, omdat hij het 'volstrekt verwerpelijk' vond hoe Fabricius 'allerlei ongunstige karaktertrekken' erbij fantaseerde: 'In verschillende krantenverslagen is de suggestie geuit, dat homoseksuele verhoudingen misschien de achtergrond vormen. Het gehele dossier bevat niets dat ook maar enigszins in die richting wijst.' (Brongersma 1964, 35). In het COC-tijdschrift Vriendschap had men minder twijfels. Daarin werd gesteld, ook na de verschijning van Fabricius' roman, dat 'het seksuele taboe op een homo-erotische relatie tussen de Baarnse broers en het slachtoffer oorzaak [was] van een gruwelijke afloop'. (Vriendschap mei 1964, 105). Met dank aan Marian van der Klein die me op dit artikel wees.
} 
aanwijzingen of enig teken van bewustzijn bij Pieter of Theo juist ontbreken, aanleiding om homoseksualiteit te vermoeden (ex negativo zogezegd). ${ }^{34} \mathrm{Ik}$ had het daar al over in hoofdstuk 2 over Letter en Geest. De onuitspreekbaarheid of ondenkbaarheid van het thema zou dan juist begrijpelijk zijn gezien de historische - en archaïsche - setting van de roman. Vriend van verdienste speelt zich af in een maatschappelijke context waarin homoseksuelen slechts schoorvoetend erkenning kregen, het COC nog een vrijwel ondergronds bestaan leidde en homoseksueel contact met minderjarigen (dat wil zeggen onder de 21) illegaal was. De afschaffing van het gewraakte artikel 248bis vond pas plaats in 1971. Homoseksualiteit was domweg niet bespreekbaar en in veel gevallen zelfs niet denkbaar voor de betrokkenen zelf. In die context kan het als betekenisvol worden gelezen dat Pieters perspectief in de roman totaal ontbreekt.

Aan het eind van de roman is de perversie, de omkering van alle waarden, compleet. Theo wil zich niet langer in dienst van Otto stellen, hij wil dat Otto hem ten dienste is. Rokko, aan wie hij zo gehecht was, noemt hij een slechte vogel. Het drinken uit de emmer, waarbij hij zich eerst een indiaan voelde bij diens initiatieritueel, verwerpt hij nu als laf toegeven aan de dorst. Eerst stond Theo's naam op de muren geschreven, als hij het kamertje verlaat 'schrijft' Pieter nog iets met zijn zaklantaarn op de muur. Otto is niet langer degene die geld betaalt voor bewezen diensten, integendeel, Theo deelt geld uit aan Otto en Pieter - het dat hij eerder met zijn diefstal verdiend had. Tenslotte wordt Theo Pieter - hij krijgt diens paspoort en zijn horloge en ze ruilen van overhemd. Daarmee is de gedaanteverwisseling waar Theo zo naar verlangde voltooid. Die wordt nog eens bevestigd wanneer Theo voor het laatst in de theekast kijkt. Er ligt een deken overheen, de spiegels zijn donker: er is geen 'ander' meer te zien.

\section{MOEDERS EN ZONEN}

In het paranoïde gotieke plot treden verdubbelingen op, en wordt het mechanisme van moderne homofobie zichtbaar doordat vrouwen van het toneel verdwijnen als bemiddelaars tussen mannen. Ook in Vriend van verdienste gebeurt dat, zo bleek in het voorgaande. Niettemin keert er een vrouw terug in het verhaal: de moeder van Pieter en Otto. Je zou het een terugkeer van het verdrongene, the return of the repressed, kunnen noemen, zij het dat de verdringing hier niet een onbewust psychologisch proces is, maar de letterlijke marginalisering

\footnotetext{
${ }^{34}$ Dat is vergelijkbaar met de manier waarop schrijfsters in de jaren vijftig het lesbische verhullen. Pamela Pattynama noemt dit 'strategische maskering': 'literair lesbisch verlangen heeft in de jaren vijftig de vorm aangenomen van een geheim en van camouflage' (Pattynama 1991, 252).
} 
van deze vrouw in haar eigen huis. $\mathrm{Zij}$ neemt echter geen bemiddelende rol (meer) in, het is een terugkeer with a vengeance. ${ }^{35}$

Het grootste deel van de roman speelt moeder Van Hal geen rol. De eerste keer dat zij ter sprake komt zegt Pieter: 'Mijn moeder is volslagen gek' (37). Zij logeert vanwege haar slechte gezondheid vaak bij haar zus. Als Theo haar in een limousine ziet arriveren bij de villa, loopt ze met een stok. Ze wordt dus afgebeeld als zowel mentaal als fysiek zwak. Ook haar positie in het gezin is verzwakt. Haar man heeft een minnares, die beschreven wordt als een 'elegante dame' (197), terwijl zijzelf gekleed is 'als een kwezel' (197). Pieter legt aan Theo uit dat zijn moeder de naam van de villa heeft verandert in De Toorts, symbool voor het gezin Van Hal. 'Maar je moet natuurlijk nooit de naam van een huis veranderen, dat brengt geen geluk...' (186) voegt hij eraan toe, daarmee suggererend dat de poging van zijn moeder om haar gezin in een beeld van eenheid te vangen juist de desintegratie bevorderd heeft. Pieter en Otto gaan volstrekt hun eigen gang, en laten zich noch aan hun vader, noch aan hun moeder veel gelegen liggen.

De moeder van Pieter en Otto keert echter terug in het verhaal als spookachtige verschijning. Theo, zelf ook ronddwalend in de villa, ziet op slag van middernacht een meisjesachtige gestalte in een wit nachthemd en met lang loshangend haar door de gangen schrijden. Het duurt even voor hij beseft dat het de moeder van Pieter en Otto is - 'geen meisje, maar een oudere vrouw' (217) - die met 'geschminkte ogen' en gestifte lippen rondwaart. Moeder Van $\mathrm{Hal}$ is van vrouw des huizes verworden tot een spookachtige hoer - 'zij had zich opgeschikt als een straatbloem' (217), denkt Theo. Zij roept steeds 'Niet in dit huis!', en is daarmee het tegenovergestelde van het huiselijk ideaal waarin de vrouw het centrum van veiligheid en huiselijkheid vertegenwoordigt. Ook de minnares bevindt zich op dat moment in de villa, en het ligt dan ook voor de hand te veronderstellen dat de moeders aanklacht tegen haar concurrente is

\footnotetext{
${ }^{35}$ Carolyn Dever (1998) stelt dat de veelvuldig afwezige moeder (dood, verdwenen) in de Victoriaanse roman enerzijds overeenstemt met de werkelijkheid (door de grote kraamsterfte van vrouwen), maar anderzijds cruciaal is voor de constructie van de 'goede moeder' als cultureel ideaal. De Victoriaanse roman put daarbij uit de gothic novel: 'the mother is constructed as an emblem of the safety, unity and order that existed before the very dangerous chaos of the child's Gothic plot (Dever 1998, 24). Als de verloren moeder plotseling weer opduikt in het verhaal, zij het als spook, of als hervonden ouder, dan leidt die terugkeer altijd tot nieuwe verstoringen van de min of meer stabiele identiteit die het personage had weten op te bouwen, zo laat Dever overtuigend zien. Dat Rosenboom dit literaire motief probleemloos kan overhevelen naar de twintigste eeuw, terwijl de kraamsterfte inmiddels gedecimeerd is, kan geïnterpreteerd worden als een voortleven van het culturele ideaal van de goede moeder, of als een extra archaïserend element.
} 
gericht, maar in Theo's oren is het 'of zij hem aanriep' (218). Theo vlucht, om niet ontdekt te worden.

Ook Theo is een spook, dat wil zeggen dat hij op een plek is waar hij niet hoort te zijn. ${ }^{36}$ Otto noemt hem op zeker moment zelfs expliciet zo: 'Hij is een spook geworden' legt Otto aan Freddie uit (242). Theo neemt structureel in feite net zo'n positie in als de moeder, al is hij zich dat niet bewust - even buitengesloten, even ongewenst in de villa, net zo'n spookachtige aanwezigheid. Net als Pieters moeder klopt hij die nacht tevergeefs op Pieters deur. Net zoals Theo vanuit de marge 'challenges the master' (Kristeva), zo doet mevrouw Van Hal dat ook. Al wordt zij gemarginaliseerd als echtgenote en als moeder, toch speelt ze een beslissende rol, die herinneringen oproept aan het optreden van Bertha Mason in Charlotte Brontës gotieke roman Jane Eyre (1847), de madwoman in the attic.

Bertha Mason steekt Thornfield Hall, het huis waarin zij jaren zat opgesloten, in brand. Het is een wrakkoefening waarmee ze haar wettige echtgenoot Rochester ernstig verminkt, maar die ze zelf met de dood moet bekopen. Villa De Toorts gaat weliswaar niet in vlammen op, maar ook dit huis wordt 'bespookt' door de wettige echtgenote, te weten mevrouw Van Hal. Net als Bertha Mason verschijnt zij op een cruciaal moment als een engel der wrake. Al roept ze niet onmiddellijk onheil af over zichzelf, zoals Bertha Mason, ze treft zichzelf wel door onheil af te roepen over haar zoon Pieter.

Op het moment dat de broers Theo - de mad boy in the attic - naar buiten brengen, waar hij door Freddie vermoord moet worden, roept hun moeder naar hen vanuit de kelder, waaruit 'de ranzige geur van fruit' (259) opstijgt. Eerder werd al over die kelder gezegd 'alsof er in die kelder een dier gevangen werd gehouden dat niet mocht ontsnappen' (57). Opnieuw krijgen Theo en mevrouw Van Hal een vergelijkbare structurele positie in de marge - hij komt van het ranzige torenkamertje, zij vanuit de kelder. Beiden 'horen' eigenlijk opgesloten te zitten. Moeder Van Hal, 'in het witte gewaad en met de haren los' (259), ziet Theo aan voor Pieter, en roept hem bij zijn naam. In de consternatie die dan ontstaat weet Theo alleen naar buiten te lopen. Met de aanroep door Pieters moeder wordt Theo's wens om Pieter te worden vervuld, en bezegelt moeder Van Hal het lot van haar zoon. De moeder als symbolische bron van identiteit en waarheid wordt hier geperverteerd - als zelfs zij haar kind niet herkent, verliest dat definitief zijn identiteit. Dat betekent het einde van Pieters leven. Als Pieter naar buiten rent, meent Freddie Theo te herkennen aan zijn blouse

\footnotetext{
${ }^{36}$ Zie Peeren (2007) voor het spook als een verstoring van ruimte in plaats van tijd, die vrouwelijk gegenderd is.
} 
en slaat hem, zoals afgesproken, neer. Niet alleen is Theo Pieter geworden - hij heeft van kleren geruild en Pieters paspoort gekregen -, maar ook andersom. Pieter moet sterven opdat Theo kan worden wedergeboren en als de 'nieuwe jongen' verder kan leven. Pieter fungeert als zondebok. Met Pieter sterft degene die vrijwel nergens in de roman focaliseert, die Theo een maandlang verzorgde, en op wie het meest de 'verdenking' van homoseksualiteit viel.

Als Theo aan het eind nog een keer omkijkt naar het huis beseft hij nog altijd niet waaraan hij is ontsnapt: 'Het was hem of het huis, onder welks schutse hij zo lang geleefd had, zich nu tegen hem keerde en zijn vervloekingen als de donder over hem heen joeg; de aanblik van het hoge, steile gebouw boezemde hem angst in.' (260). Deze waarneming vormt een schril contrast met zijn eerste indruk (toen het huis plechtigheid en recht uitdrukte). Het illustreert Theo's gebrek aan besef van de toestand waarin hij zich bevindt: hij begrijpt niet dat hij net aan de dood ontsnapt is, net zomin als hij aan het begin besefte dat de villa eerder verdorvenheid dan recht herbergt.

\section{HET ANACHRONISME VAN DE SEKSUELE ONSCHULD}

De setting van gotieke romans in een premodern verleden is op te vatten als een vaak ambivalent - commentaar op het moderne heden, waarin nostalgie en opluchting om de voorrang strijden. Het 1966 dat Vriend van verdienste presenteert doet archaïsch aan, zoals ik aan het begin van dit hoofdstuk constateerde. Hoe functioneert het gotieke in de herwerking van de erfenis van de jaren zestig?

In de homosociale rivaliteit tussen de jongens, die ik met behulp van Sedgwick (1985) beschreef, vallen enkele zaken op. Zo begeeft Theo zich niet 'als man' in de strijd, maar daagt hij juist als niet-man de orde (waarvan Otto de standaard vormt) uit. Hij kan geassocieerd worden met vrouwelijkheid door zijn huishoudelijke werk, hij is sociaal mindere door zijn klasse, en bovendien de jongste. Hij is in alle opzichten de mindere en lijkt zo gedoemd de strijd te verliezen. Toch weet hij de orde te ondermijnen. Mannelijkheid komt in het nauw: zowel Otto (die de 'oude' orde belichaamt) als Freddie (de 'nieuwe' man) voelen de dreiging van homoseksualiteit. Homosociale rivaliteit lijkt afwezig tussen Theo en Pieter, wiens (fysieke) gelijkenis met Theo wordt benadrukt. Pieter fungeert als dubbelganger van Theo, diens ideaal en schutsengel, een positie die Pieter met de dood moet bekopen. Pieter is ook de enige die geen fysiek geweld gebruikt, die niet aan paranoia lijdt en die in gelijkwaardigheid tussen hem en Theo lijkt te geloven. In het contact tussen Theo en Pieter wordt meermalen de suggestie van een homo-erotische bijbetekenis gewekt. Dat die 
bijbetekenis door de twee betrokkenen zelf niet lijkt te worden gevoeld, geeft de roman een haast opzettelijke seksuele onschuld.

Juist die onschuld doet archaïsch aan. De historische setting van de roman suggereert dat hier een verleden wordt geschetst dat 'wij', hedendaagse lezers, inmiddels achter ons hebben gelaten. Vriend van verdienste ensceneert, als veel klassieke gotieke romans, conflicten die de voortschrijdende modernisering oproept. De roman, die ik aanduidde als een microkosmos van de jaren zestig, laat zien wat er gebeurt als voorheen duidelijke categorieën dreigen te gaan schuiven. Van een rimpelloze modernisering zoals James Kennedy (1995) schetste, blijft in de context van Vriend van verdienste weinig over. Via het gotieke, met zijn preoccupaties met geweld en het abjecte, wordt de ondermijning van de maatschappelijke orde vormgegeven. Niet alleen de van oudsher geprivilegieerde positie van de hogere klasse komt onder druk te staan, maar ook de mores van de lagere klasse, de middenstand waarvoor dienstbaarheid in deze roman wordt gerepresenteerd als een kwestie van eer.

Vriend van verdienste verwoordt via het gotieke spanningen tussen macht en onmacht, afhankelijkheid en onafhankelijkheid. Theo benadrukt keer op keer dat hij niet verantwoordelijk is voor zijn daden: hij staat onder invloed van Freddie, en hij geeft de schuld van zijn slechte daden aan zijn situatie - zijn leven zonder moeder, met een broer in een opvoedingsgesticht en een vader die te weinig aandacht aan hem besteedt. Herhaaldelijk zegt hij dat hij niet vrij is. Hij verwoordt daarmee een idee over subjectiviteit dat bepaald deterministisch aandoet. Ondertussen zet hij dat deterministische idee in om zijn omgeving te manipuleren. Hij gebruikt zijn onvrijheid als een succesvol pressiemiddel om zijn eigen doelen te verwezenlijken, en dat geeft zijn gebrek aan autonomie een behoorlijk autonome draai. Theo belichaamt daarmee als het ware de spanningen tussen een oude en een nieuwe orde. Twintig jaar later is, via de maakbare samenleving, de individuele autonomie tot maatschappelijke norm verheven, niet alleen voor de elite, maar ook voor de 'kleine man'.

De jongens staan in verschillende opzichten op de drempel van een nieuwe tijd - Otto staat op het punt om te gaan studeren, voor alle vier geldt dat ze zich bijna volledig aan het ouderlijk gezag onttrekken. Het historische moment waarin ze leven - 1966 - markeert de overgang naar een tijd waarin de autonomie van jongeren enorm zal toenemen, en de macht van ouders op zijn zachtst gezegd geherdefinieerd zal worden. De conflicterende maatschappelijke ideologieën leiden in deze gotieke roman, zoals in vele andere, tot een strijd op leven en dood. Het is misschien ironisch, maar ook wrang, dat de uitkomst van die strijd in deze roman uiteindelijk niet bepaald wordt door de vechtersbazen zelf, maar door hun moeder. 



\title{
5
}

\section{DE GOTIEKE STEMMEN VAN RENATE DORRESTEIN}

\author{
Noorderzon en Het perpetuum mobile van \\ de liefde
}

Hella Haasse was de eerste die uitgebreid aandacht besteedde aan het gotieke in de romans van haar jongere collega Renate Dorrestein (Haasse 2000). Haasse pikte de verwijzing naar het gotieke op uit Dorresteins vijfde boek Het perpetuum mobile van de liefde $(1988)^{1}$, waar die schrijft dat het genre van de gotieke literatuur 'niet voor niets door vrouwen groot is geworden' (Dorrestein geciteerd in Haasse 2000, 283). Mede dankzij Haasses essay is Renate Dorrestein inmiddels de Nederlandse auteur die het vaakst met het gotieke wordt geassocieerd. In recensies van en advertenties voor Dorresteins werk wordt geregeld verwezen naar de gothic novel en er zijn diverse beschouwingen vanuit een gotiek interpretatiekader aan haar romans gewijd. ${ }^{2}$ Inmiddels wordt Dorrestein

\footnotetext{
${ }^{1}$ In het vervolg afgekort tot Perpetuum mobile.

${ }^{2}$ Dorrestein plaatste zich eerder in een interview in De Tijd (1987) expliciet in de traditie van de gothic novel, maar daar verwijst Haasse niet naar: 'Ik pas in een lange en rijke traditie van vrouwen die schreven om niet in hun verzet te hoeven stikken en die uitgekookt genoeg waren om het onzegbare buiten de officiële werkelijkheid te situeren. Met deze schrijfsters deel ik een voorliefde voor grotten, kastelen en andere geïsoleerde plaatsen waar het kwaad zich onherroepelijk zal voltrekken: ik heb het over de schrijfsters van de diabolische sprookjes die wij gothische literatuur noemen.' (Dorrestein 1987, 53). De eer voor de eerste vermelding van het gotieke in verband met Dorrestein gaat waarschijnlijk naar Maarten 't Hart. In zijn recensie van Noorderzon merkt hij op dat ze 'in veel opzichten terug[grijpt] op het genre van de gothic novel'. Hij vindt haar gothic sprookjes 'wel erg ouderwets' ('t Hart 1986). Recensies waarin Dorrestein in verband wordt gebracht met het gotieke: bijvoorbeeld Schutte (1992, 1994, 1999); Pruis (2000), Steinz (1998,
} 
ook in schoolboeken als auteur van gothic novels besproken: daarmee lijkt haar status als gotieke auteur definitief gevestigd. ${ }^{3}$

In haar essay, gewijd aan Dorresteins eerste vier romans ${ }^{4}$, stelt Haasse dat Dorresteins keuze voor de gotiek niet diende 'om een modieus-gotiek gat in de markt te vullen' (Haasse 2000, 284), maar een innerlijke noodzaak was. ${ }^{5}$ Het gotieke zou Dorrestein in staat hebben gesteld de zelfmoord van haar zusje te verbeelden en haar eigen schuldgevoelens daarover te verwerken en bewerken. De afgelegen locaties, de dreigende sfeer en de steeds fantastischer elementen in Dorresteins eerste romans leest Haasse, met terugwerkende kracht, als middelen om de onuitspreekbare werkelijkheid van de dood van het zusje te verbeelden. Ze laat zich bij die interpretatie leiden door wat Dorrestein zelf schrijft in Perpetuum mobile:

Sprong mijn zusje van een flatgebouw haar dood tegemoet? Ha! Dan duw ik in mijn werk zoveel mogelijk personages van daken, balkons of rotsen en zie: mijn pen geeft hun nog net op tijd vleugels. Echte, mythologische of overdrachtelijke wieken, geen moeite is mij teveel. (Dorrestein 2002, 37-38)

Behalve deze autobiografische motivatie voor Dorresteins gebruik van het gotieke, ziet Haassse ook een verband met haar feminisme. Ze stelt dat Dorrestein, net als andere schrijfsters - van Ann Radcliffe tot Angela Carter -, het gotieke verhaal gebruikt om vrouwelijk onbehagen te verwoorden: 'In Renate Dorresteins romans lijkt het identiteitsprobleem van vrouwen nauw verweven met een uiterst ambivalente houding ten opzichte van hun vrouwelijkheid' (Haasse 2000, 291). Het gotieke zou vrouwelijke auteurs specifieke mogelijkheden bieden, volgens Haasse:

Symbolen van dood en nacht, verval, gruwel, dreiging en geheim schijnen zich bij uitstek te lenen voor verbeeldingen van onzekerheid en angst die te

2006). Uitgebreidere beschouwingen: Gaigher (2000), Buikema (2001, 2003), Buikema \& Wesseling (2000, 2006, 2006a, 2007). Zie ook Dorresteins eigen website, www.renatedorrestein.nl.

${ }^{3}$ Zie Buikema (2001).

${ }^{4}$ Buitenstaanders (1983), Vreemde streken (1984), Noorderzon (1986), Een nacht om te vliegeren (1987).

${ }^{5}$ Op zichzelf al een interessant citaat van Haasse, want kennelijk was er dus zoiets als 'een modieus-gotiek gat in de markt' - dat wijst erop dat het gotieke bloeide in de literatuur van de jaren tachtig. Haasse doelde wellicht op de twee bundels met nieuwe, oorspronkelijk Nederlandse griezelverhalen die Robert-Henk Zuidinga kort daarvoor samenstelde: Uit den boze (1984) en Boosaardig (1986), wat voor- en nadien niet meer vertoond is. Dorrestein leverde een bijdrage aan de tweede bundel. Zie ook hoofdstuk 1. 
maken hebben met de beleving van seksualiteit en met de worsteling om een zelfstandig individu te worden. (Haasse 2000, 284)

Haasse ziet die worsteling om een zelfstandig individu te worden terug in Dorresteins boeken; de 'queeste naar de eigen identiteit' (Haasse 2000, 289) vormt volgens haar de kern van het werk.

Met Perpetuum mobile als leeswijzer weet Haasse aannemelijk te maken dat het gotieke in Dorresteins vroege romans autobiografisch en feministisch geïnterpreteerd kan worden. Dorrestein heeft bovendien in interviews bevestigd dat het surrealistische van het gotieke in haar eerste romans een manier was om de realiteit van haar zusjes zelfmoord te verwerken. ${ }^{6} \mathrm{Ik}$ wil aan die analyse op zichzelf niets afdoen. Toch lees ik in dit hoofdstuk twee romans die in Haasses essay aan de orde komen, opnieuw: Noorderzon (1986) en het al genoemde Perpetuum mobile (1988). Perpetuum mobile betekende een wending in Dorresteins oeuvre; haar latere romans zijn realistischer. De conclusie zou kunnen zijn dat na Perpetuum mobile de demon van het dode zusje inderdaad was uitgedreven en dat het gotieke zijn functie had vervuld. Maar latere romans van Dorrestein mogen dan minder extreem zijn, ze zijn niet per se minder gotiek, zoals blijkt uit het feit dat Dorresteins romans ook na Perpetuum mobile als gotiek worden bestempeld. ${ }^{7}$ Daarmee is de vraag gerechtvaardigd of de autobiografische interpretatie van Noorderzon niet te veel nadruk heeft gekregen. Bovendien blijft de functie van het gotieke in Perpetuum mobile bij Haasse onderbelicht. In het kader van dit boek wil ik me afvragen wat het gotieke doet in deze twee romans van Dorrestein: hoe het gotieke zich manifesteert en wat het culturele werk is dat deze romans verrichten rond sekse en seksualiteit.

Hoewel Haasse nog een slag om de arm houdt ('schijnen zich te lenen'), viel de stellingname dat gotiek en vrouwen een voor de hand liggende combinatie vormen vanaf eind jaren zeventig vaker te beluisteren. In het eerste hoofdstuk schetste ik de levendige internationale discussie over vrouwen en het gotieke, die startte met Ellen Moers' concept van de female gothic (Moers 1978). In feministische interpretaties uit de jaren tachtig was de gotieke heldin die zich ontworstelt aan een schurkachtige patriarch een prototypische feministische figuur. Haasses interpretatie van Dorresteins gotiek, in termen van de zoektocht

\footnotetext{
${ }^{6}$ Zie bijvoorbeeld Kagie (1988), Wester (1988), De Moor (1989), Webeling (2001) en Opmeer (2003). Zie ook Van Heijst (1993), 108-109 over Haasses essay en de receptie van Perpetuum mobile.

${ }^{7}$ Bijvoorbeeld in analyses van Het hemelse gerecht (1990), Ontaarde Moeders (1991), Een sterke man (1994) en Hart van Steen (1998): zie Gaigher (2000), Buikema \& Wesseling (2000, 2006, 2006a, 2007). Zie ook Schutte (1992, 1994, 1999).
} 
naar een eigen identiteit, past bij deze feministische lezingen van het gotieke. Ook Dorrestein zelf legde het verband tussen vrouwen en het gotieke, zoals uit het citaat aan het begin van dit hoofdstuk bleek.

Het concept female gothic heeft weliswaar een ongekende impuls gegeven aan de (Angelsaksische) feministische literatuurwetenschap, maar inmiddels zijn ook de bezwaren die aan het concept kleven duidelijk geworden - ik besprak die in hoofdstuk één. Historisch letterkundige Nancy Armstrong heeft recentelijk een nieuwe wending gegeven aan het debat over feminisme en het gotieke. Ik ga uitgebreid in op haar ideeën, die in de paragrafen daarna een verrassend licht kunnen werpen op Dorresteins romans.

\section{FEMINISME EN HET GOTIEKE VOLGENS NANCY ARMSTRONG}

Nancy Armstrong leest in How novels think (2005) de geschiedenis van de roman in termen van de verhouding tussen individu en gemeenschap. Daarbij kent ze een bijzondere positie toe aan de gotieke roman. ${ }^{8}$ Voor een liberale samenleving is de verhouding tussen individu en gemeenschap een potentiële bron van spanning: het (liberale) streven naar maximale zelfexpressie van individuen botst al snel met het collectieve belang van het versterken van de sociale orde. De roman doet volgens Armstrong bemiddelend werk: 'the novel [...] was born as authors gave narrative form to this wish for a social order sufficiently elastic to accommodate individualism' (Armstrong 2005, 139).

Ze stelt dat de roman in de achttiende eeuw begon als een utopisch, idealistisch genre, dat moderne democratische waarden verspreidde. In de vroege roman leidde het verlangen van de protagonist ('individualistic energy' (79) in Armstrongs termen) tot zelfverwezenlijking van het individu én tot het oprekken van de sociale orde. In de loop van de negentiende eeuw verliest de roman echter zijn utopische karakter. Personages leren dat het goed is om zich neer te leggen bij de realiteit, en zich te verzoenen met sociale ongelijkheid en de onmogelijkheid om werkelijk iets in de wereld te veranderen. In plaats dat de gemeenschap flexibeler en inclusiever wordt, dient de hoofdpersoon 'a change of heart' (Armstrong 2005, 142) te ondergaan, een innerlijke verandering. Die stap van utopisch naar realistisch denken maakt van de Victoriaanse roman in

\footnotetext{
${ }^{8}$ Die benadering is op zich niet nieuw; Armstrong bouwt voort op het werk van met name Ian Watt, The Rise of the English Novel (1957), Georg Lukács, The Historical Novel (1962), en Herbert Marcuse, 'The Affirmative Character of Culture' (1968). Armstrong neemt wel de meest radicale positie in: zij stelt dat 'the history of the novel and the history of the modern subject are, quite literally, one and the same' (Armstrong 2005, 3).
} 
wezen een conservatief genre, aldus Armstrong. Het kerngezin wordt het model voor de samenleving als geheel; het gezin als 'hoeksteen van de samenleving' kan hier niet letterlijk genoeg genomen worden. De sociale orde wordt - cru gesteld - opgebouwd door het aantal kerngezinnen uit te breiden en steeds nieuwe burgers geboren te laten worden. Voor afwijkende individuen is in die orde steeds minder plaats.

Armstrong is als het ware teleurgesteld in de roman: die heeft zijn utopische potentieel om een steeds inclusievere gemeenschap te verbeelden niet verwezenlijkt. Op dit punt trekt ze een verrassende parallel met strategieën van feministische literatuurwetenschappers uit de tweede golf. Ook die streefden naar het oprekken van de sociale orde (opdat vrouwen er deel van uit zouden maken), maar slaagden er volgens Armstrong niet in de liberale paradox van meer individuele expressie en een inclusievere gemeenschap te overstijgen. Ze wijt dat aan het feit dat feministische literatuurwetenschappers het verkrijgen van een eigen stem, van vrouwelijke auteurs en hun protagonisten, belangrijker leken te vinden dan het verwerven van bezittingen of macht:

This move convinced a generation of readers that acquiring a voice - access to print, or what might be called cultural agency - could compensate for the forms of property that traditionally authorized the rights-bearing citizen' (Armstrong 2005, 140)

De retorische macht (van het personage, van de auteur) moest het gebrek aan (politieke en economische) macht/autoriteit compenseren. Literatuur diende daarbij als een soort model voor een utopisch streven in de werkelijkheid: ook daar gold dat het claimen van een eigen stem soms het belangrijkste doel leek. ${ }^{9}$

\footnotetext{
${ }^{9}$ Armstrong verwijst naar het indertijd invloedrijke boek van Carol Gilligan, veelzeggend getiteld In a Different Voice (1982) als een voorbeeld van die strategie toegepast op reële (i.t.t. fictionele) vrouwen. Ze licht dit toe met het volgende citaat van Gillligan: 'As we have listened for centuries to the voices of men and the theories of development that their experience informs, so we have come more recently to notice not only the silence of women but the difficulty in hearing what they say when they speak. Yet in the different voice of women lies the truth of an ethic of care [...]' (Gilligan in Arnstrong 2005, 181 noot 2). In een heel ander verband uitte Naomi Klein vergelijkbare kritiek op het feminisme als Armstrong: het zou meer bezig zijn geweest met kwesties van representativiteit dan met het verbeteren van sociaal-economische omstandigheden. Zie: Klein (1999), hoofdstuk 5: 'Patriarchy gets funky: the triumph of identity marketing'.
} 
Bovendien riepen feministen de madwoman in the attic ${ }^{10}$ uit tot de projectie van hun eigen (onderdrukte) positie als vrouw en wetenschapper, volgens Armstrong. Deze gekke vrouw, het gotieke monster, is een individu dat niet door de gemeenschap geaccommodeerd kan worden. $\mathrm{Zij}$ zou de woede vertolken van elke vrouw die zit opgesloten in een masculiene cultuur: zo werd de madwoman tot de vrouwelijke stem bij uitstek. Deze 'politiek van verschil', die gebaseerd is op het benadrukken van sekseverschil, had risico's waar feministen al begin jaren tachtig tegenaan liepen, aldus Armstrong. Door de uitsluiting van vrouwen (het gebrek aan economische en politieke macht), gesymboliseerd door de madwoman, juist als bron van retorische macht ('de vrouwelijke stem') op te vatten, werd macht op zichzelf iets corrumperends. ${ }^{11}$

Latere feministen, Armstrong zelf incluis, probeerden dat probleem te omzeilen door verschil ('feminine difference', 141) als positieve bron van autoriteit te definiëren, en het verschil c.q. gebrek niet zozeer op te vatten als de natuurlijke staat van het vrouw-zijn, maar als het resultaat van culturele instituties die macht en privileges reserveerden voor mannen. Toch bleef het een problematische strategie, omdat essentialisme op de loer bleef liggen.

Tegenover feministen zoals Moers c.s., die het gotieke lezen als 'vrouwelijke stem' in de literatuur, als expressie van de onderdrukking van vrouwen, zet Armstrong nu een andere lezing van het gotieke. Ze vestigt de aandacht op het utopisch potentieel van het gotieke in een fascinerend hoofdstuk over Bram Stokers Dracula. Hoewel ze niet ontkent dat Stokers visie een sombere is, ziet ze iets utopisch in de manier waarop sociale verbanden in Dracula worden gevormd: namelijk op een radicaal inclusieve manier. Zodra een slachtoffer gebeten is door de vampier wordt hij/zij deel van een collectief. Alles wat het individu denkt, weet het collectief, verschillen worden uitgewist.

De vampier (Dracula, en zijn slachtoffers) markeert het einde van het individualisme, van individueel verlangen. De roman heeft dan niet langer de functie om de gemeenschap te beschermen tegen excessief individualisme, zoals de

\footnotetext{
${ }^{10}$ De madwoman in the attic is een verwijzing naar Bertha Mason in Jane Eyre en naar het inmiddels klassieke boek van Sandra Gilbert \& Susan Gubar, The Madwoman in the Attic: The Woman Writer and the Nineteenth-Century Literary Imagination (1979). In Nederland besprak Pruis (2000) vrij recent nog het idee dat verdrukte vrouwelijke creativiteit en seksualiteit in literatuur wordt gesymboliseerd door gekooide en gekke vrouwen als Bertha Mason.

${ }^{11}$ In feite schetst Armstrong hier het oude gelijkheid-verschil dilemma dat het feminisme spleet in de jaren tachtig. Moeten feministen proberen de ongelijkheid tussen mannen en vrouwen op te heffen door verschillen tussen de seksen te benadrukken, of juist niet? Dat probleem bleek principieel onoplosbaar, zoals onder anderen Joan Scott liet zien: gelijkheid en verschil zijn relationele begrippen - gelijkheid kan alleen gedefinieerd worden op basis van een welomschreven verschil (Scott 1986, 1989, 1999 [1988]).
} 
realistische roman. De vampier creëert een radicaal inclusieve gemeenschap, die ertoe leidt dat de door het kerngezin genaturaliseerde sekseverschillen verdwijnen. Het kerngezin en het liberale, autonome individu worden door het gotieke tot achterhaalde begrippen verklaard.

Feministen zouden ideeën kunnen putten uit gotieke romans als Dracula omdat daarin de relatie tussen individu en collectief radicaal anders wordt geformuleerd. Armstrong verwijst naar Donna Haraway, die stelde dat het tijd werd 'to theorize an "unfamiliar" unconscious, a different primal scene, where everything does not stem from the dramas of identity and reproduction. [...] I think I am on the side of the vampires, or at least some of them' (Haraway in Armstrong 2005a, 21, noot 20). Armstrong beschouwt het gotieke met andere woorden als mogelijk alternatief voor de ideologie van het moderne individualisme, en voor de logica van het 'natuurlijke' kerngezin als model voor de maatschappij. De gotieke roman ondermijnt die logica door alternatieve vormen van verwantschap voor te stellen, al laat het ook zien dat het ontkennen van het moderne individu monsterlijke effecten heeft.

Armstrong schuwt het sweeping statement niet, en roept Britse fictie zonder veel voorbehoud tot centrum van de wereld uit. Een ernstiger bezwaar is wellicht dat haar boek ophoudt bij 1900, al doet ze in enkele terzijdes wel uitspraken over de hedendaagse roman. Zo stelt ze dat elke roman, wil hij nog als zodanig herkenbaar zijn, zich dient te verhouden tot de ideologische kern van het moderne individualisme: ' $[\mathrm{N}] \mathrm{ew}$ varieties of novel cannot help taking up the project of universalizing the individual subject' (Armstrong 2005, 10). Die kern is dat romans, net als individuen, nadenken over de vraag hoe men zichzelf kan verwezenlijken als individu. Armstrong gaat hier gemakshalve voorbij aan een belangrijk hoofdstuk in de ontwikkeling van roman: het modernisme. ${ }^{12}$ Bovendien is de maatschappelijke functie van de roman ten opzichte van de negentiende eeuw onmiskenbaar kleiner geworden.

Ondanks die bezwaren vind ik haar theorie over het moderne individu en het gotieke interessant voor mijn onderzoek en neem ik de vrijheid om die theorie mee te nemen naar het laattwintigste-eeuwse werk van Dorrestein. De parallel tussen romanstrategieën en tweede-golffeminisme is juist in het geval van Renate Dorrestein boeiend om nader te onderzoeken: Dorrestein was in de jaren tachtig berucht om haar scherpe columns voor het feministische tijdschrift Opzij. Het is bovendien opvallend dat Haasse Dorresteins gebruik van het go-

\footnotetext{
${ }^{12}$ Modernisten hebben zich ook intensief gebogen over de verhouding tussen individu en collectief, en zij hebben de manieren waarop die (kan) worden verbeeld, ingrijpend veranderd. Denk bijvoorbeeld aan de manier waarop transindividuele aspecten van het bewustzijn worden verbeeld in Virginia Woolfs Mrs Dalloway (1923).
} 
tieke verwoordt in vergelijkbare termen als Armstrong, als het emancipatorisch streven van een individu ('de worsteling om een zelfstandig individu te worden'). De bemiddeling van romans in de verhouding tussen individu en collectief is nog steeds actueel. Ik wil het verschil tussen een female gothic lezing zoals Haasse die deed en Armstrongs benadering allereerst laten zien aan de hand van Noorderzon. Vervolgens ga ik nader in op de thematiek van individualisme en de vrouwelijke stem in Perpetuum mobile.

\section{NOORDERZON EN FEMALE GOTHIC}

De hoofdpersoon van Noorderzon, Topaas, ontvlucht haar eigen leven nadat ze - dronken op de fiets - een dodelijk ongeluk heeft veroorzaakt. Haar botsing met een auto was fataal voor de bestuurster, Lin Anemoon Savitra, lid van een sekte en onderwijzeres van zwakbegaafde kinderen. Topaas is sindsdien bang dat ze het Boze Oog bezit, en hoopt dat kwijt te raken door boete te doen op een eiland dat legendarisch is om zijn verzoenende krachten. Op het eiland ontmoet ze onder anderen de doofstomme jongen Wants, die als een beest aan de ketting wordt gehouden door zijn ouders Spider en Andrena, bij wie Topaas verblijft. Door hem onder haar hoede te nemen hoopt ze Lins plaats in te kunnen nemen. Haar goede bedoelingen leiden echter tot een reeks absurde en steeds gewelddadiger gebeurtenissen. Als Wants sterft, en de toorn van de eilanders zich tegen haar lijkt te richten, weet Topaas ternauwernood te ontsnappen. Ondertussen is ze nagereisd door haar minnaar Julius, en haar jonge onderhuurster Justine, die een oogje op Julius heeft. Zij lijken ertoe veroordeeld om Topaas' plaats op het eiland in te nemen.

Er zijn weinig boeken waarop het motto 'gothic signifies a writing of excess' (Botting 1996, 1) zozeer van toepassing is als Noorderzon - aan alle kanten lijkt deze roman uit zijn voegen te barsten en grenzen te overschrijden. Om te beginnen is Noorderzon een excessief verhaal, zowel qua inhoud als qua vorm. Het verhaal kent een verwarrend verloop met de ene plotwending na de andere, en zit vol zijsprongen. Op de roman als geheel is van toepassing wat over de verhalen van hoofdpersoon Topaas wordt gezegd:

Onveranderlijk verkozen daarin spontane vertakkingen en woekeringen uit te botten. Uit de ene geschiedenis puilde vanzelf de volgende tevoorschijn, totdat ze als een tros in elkaar verknoopt raakten en Topaas zelf moest toegeven: "Dit wordt meer een bundeltje". (9) 
Ook de verteltechniek is grensoverschrijdend te noemen. Noorderzon is grotendeels gestructureerd als een briefroman in een modern jasje: Topaas stuurt cassettebandjes, geadresseerd aan Justine, en doet daarop verslag van haar belevenissen. De inhoud van de bandjes vormen een groot deel van de roman.

In het verhaal worden vele geografische grenzen overschreden: Topaas reist van Nederland eerst naar het zuiden en vervolgens naar 'het noordelijkste punt van het vasteland' (13), om dan over te steken naar een onbekend en misschien zelfs niet-bestaand eiland: het was nog 'terra incognita' (145) toen de nieuwe wereld al was ontdekt. Het eiland bevindt zich over de grenzen van de moderne wereld: '[ $\mathrm{t}$ ]ot op de dag van vandaag was het in de meest strikte zin van het woord een achtergebleven gebied' (145-146). Het vooruitgangsdenken dat uit het woord 'achtergebleven' spreekt, maakt het eiland tot een anachronisme het is niet met de tijd meegegaan, en dat blijkt uit de afstand in ruimte. Die combinatie van een vooruitgangsvertoog, anachronisme en geografische afstand is volgens Robert Mighall (1999) kenmerkend voor het gotieke. En inderdaad is het eiland een gotieke locatie, bewoond door gotieke personages: corrupte monniken, een mediamieke, raaskallende vrouw (vrouw Flata) en haar drie achterlijke zonen, een incestueuze broer en zus (Spider en Andrena) met hun doofstomme, mismaakte nakomeling (Wants), en de zwart gemaskerde stoker (Carebara), die een voormalig nazi blijkt. ${ }^{13}$

Topaas is tot op zekere hoogte een twintigste-eeuwse versie van Radcliffes gotieke heldin. Ze is een moderne vrouw die letterlijk verdwaald raakt in een archaïsche context, en daar een aantal geheimen op het spoor komt. Het archaïsche karakter van het eiland blijkt behalve uit zijn afgelegen ligging bijvoorbeeld ook uit de stand van de technologie: 'Brachten satellietverbindingen de hele wereld in ieders huiskamer, met dit eiland zou telefoneren niet eens mogelijk zijn.' (146). Topaas ervaart het bij aankomst als onoverzichtelijk: 'Waar reden we toch helemaal heen? Zo groot was het eiland toch niet?'(35). Als ze op onderzoek uitgaat in het klooster verdwaalt ze:

$[\mathrm{W}]$ at daareven nog tamelijk overzichtelijk had geleken, zag er plotseling uit als het oude hart van een mediterrane stad. Er waren alkoven die naar terrassen leidden, doorgangen die eindigden in blinde muren, donkere sleuven die in grote holle ruimtes uitkwamen. Wenteltrappen die ze nog niet eerder

\footnotetext{
${ }^{13}$ Deze namen verwijzen naar spinnen (Spider) en insecten (Wants is een soort mijt, Andrena is een soort bij, Carebara is een soort Zuid-Amerikaanse mier). Flata is Zweeds voor 'plat'. Dorrestein schrijft in Het geheim van de schrijver (2000) dat ze de namen koos om de recensenten dwars te zitten die in eerdere romans naar diepere betekenissen van haar naamgeving hadden gezocht: 'Er kwam geen enkele reactie, maar dan ook geen enkele.' (Dorrestein 2000, 189).
} 
had betreden, brachten haar weer naar vertrekken die ze zojuist had verlaten. [...] De stokerij leek zo mogelijk een nog omvangrijker labyrint dan de rest van de abdij. (63)

In het hart van dit gotieke labyrint treft Topaas de stoker Carebara aan, in zijn monsterlijke uitmonstering. Gekleed met zwart leren masker en handschoenen gaat hij door het leven, omdat hij getekend zou zijn door een ziekte. Hij onthult haar een van de geheimen van het eiland: hoe het werd getroffen door ongeluk toen alle kinderen op een nacht doodvroren in de bergen. Topaas ontdekt vervolgens zelf hoe de eilanders zich onder leiding van Carebara en Andrena aan drank- en seksorgies overgeven in de abdij, in de hoop op nieuwe nakomelingen, en hoe ze passerende schepen op de klippen laten lopen om ze te plunderen. Ze vreest de reactie van de eilanders op haar ontdekkingen: zal ze nu worden verdreven? Topaas lijkt zich - als een echte gotieke heldin - door haar nieuwsgierigheid in de nesten te werken.

In een aantal opzichten verschilt Topaas echter van de achttiende-eeuwse damsel-in-distress. De klassieke patriarchale bedreigingen - een aristocratische schurk, een bedreigende religie of een autoritaire vader - ontbreken. De mannen in Noorderzon zijn geen tirannen. Hoewel Spider enige seksuele avances maakt (waarvoor Topaas niet ongevoelig blijkt), is hij bepaald geen Montoni of Schedoni, de schurken uit Radcliffes romans. Spider blijkt onder de plak te zitten van zijn zus Andrena, die hem in een vernederende scène dwingt Topaas zijn verontschuldigingen aan te bieden voor zijn 'opdringerige gedrag' (72). De abt is oud en dronken en vormt ook geen gevaar. De stoker Carebara lijkt de verpersoonlijking van het kwaad. Niet alleen neemt hij structureel de positie in van het monster in het hart van de labyrintische abdij, hij is ook een voormalig nazi in SM-achtige kleding en lijkt het eiland in zijn macht te hebben met zijn zelfgestookte whisky. Carebara is echter juist degene die Topaas met zijn gewetensvragen dwingt eerlijk te zijn tegen zichzelf - een kwelgeest, maar niet het kwaad. De kwade genius van het eiland blijkt een vrouw te zijn: vrouw Flata, die met Andrena in een strijd om de macht is verwikkeld.

Topaas is bovendien geen Radcliffeaanse heldin in de zin dat (haar) familiegeheimen het plot bepalen, of dat ze een dochter in de huwbare leeftijd is. Haar maagdelijkheid staat niet op het spel. Topaas is een volwassen vrouw: ze heeft 'duidelijk [...] haar dertigste verjaardag achter zich [...] liggen' (8). Haar minnaar Julius is geen despoot, al vindt hij Topaas wel erg avontuurlijk: 'Het was natuurlijk fascinerend dat ze anders was dan enige vrouw die hij ooit was tegengekomen, maar in sommige opzichten ging ze te ver' (32-33). Topaas is fel tegen een huwelijk gekant, vanwege 'het feit dat mensen eerst moeten trouwen 
om als compleet te worden aangemerkt' (67). Doordat ze niet getrouwd is, komt haar seksuele autonomie op het eiland wel op het spel te staan: een vrouw alleen blijkt kwetsbaar.

De mannen afzonderlijk mogen dan een krachteloze indruk maken, er gaat wel dreiging uit van het collectief. Dat geldt met name voor de mannen in de kroeg, die elkaar sterke verhalen over vrouwen vertellen, en de drie achterlijke zoons van Flata, bijgenaamd 'de horzelkoppen'. Zij zijn de exponenten van een ideologie die vrouwen slechts als seksueel object of als moeder ziet. Dat zou geïnterpreteerd kunnen worden als een teken van de archaïsche toestand van het eiland, maar zo scherp is de scheiding met de moderne wereld nu ook weer niet. Ook op de niet-dominante, 'moderne' Julius heeft die ideologie nog vat: 'het werd tijd dat ze met hem trouwde en baby's kreeg. Bij wijze van grapje zei hij soms dat het slecht afliep met vrouwen die hun natuurlijke bestemming negeerden' (36). ${ }^{14}$ Als Topaas aan het eind van de roman wordt belaagd door de drie zoons van Flata, ontsnapt ze aan een wisse verkrachting doordat ze ongesteld is: de ontdekking van bloed maakt dat de 'horzelkoppen' zich van haar afkeren. Van object is ze abject geworden. Vrouwelijke lichamelijkheid is het beste wapen tegen mannelijke belagers; en zo wordt de patriarchale dreiging in deze roman afgewend. ${ }^{15}$ De beschrijving van de ongesteldheid van de heldin, die de sleutel vormt tot haar ontsnapping, is een feministisch-realistisch detail in deze niet-realistische roman.

Hella Haasse vatte vrouwelijke gotiek op in termen van de 'angst en onzekerheid over beleving van seksualiteit' en 'de worsteling om een zelfstandig individu te worden'. Die thema's gaan maar ten dele op voor Noorderzon. Topaas hoeft thuis, in haar eigen leven, geen emancipatorisch gevecht meer te voeren. $\mathrm{Zij}$ is bijzonder zelfstandig, in seksueel en economisch opzicht - met een minnaar en een baan als hoorspelproducent bij de radio. Anders dan in De vierde man is die vrouwelijke autonomie geen bron van gotieke dreiging - althans in het 'gewone' leven. Julius kan zijn ideeën over de 'natuurlijke bestem-

\footnotetext{
${ }^{14}$ Dat Julius' dagelijks werk als gynaecoloog bestaat uit het verwijderen van baarmoeders is dan ook ironisch te noemen.

${ }^{15}$ Deze expliciete lichamelijkheid kan ook grotesk genoemd worden. Ook vrouw Flata en Wants hebben groteske lichamen. Catherine Spooner schrijft over het gotieke en het groteske: 'grotesque bodies in Gothic are not always comic or affirmative of the life of the body and the people - in fact, they are more frequently sinister and disturbing' (Spooner 2006, 68). Hoewel Noorderzon onmiskenbaar humoristische kanten heeft - bijvoorbeeld als Justine haar onnozelheid tentoonspreidt 'Werkt de televisie eigenlijk op elektriciteit?'(37), overheerst bij Wants en Flata het verontrustende aspect. Zie Hurley (2007) voor een bespreking van verschillen en overeenkomsten tussen het abjecte en het groteske. Voor een Nederlandse studie over het groteske zie Van den Oever (2003).
} 
ming' van vrouwen alleen 'bij wijze van grapje' uiten. Wel staat Topaas' zelfstandigheid onder druk op het archaïsche eiland. Ze is daar afhankelijk van het krediet - letterlijk en figuurlijk - dat ze krijgt van de bewoners. Ze heeft alleen ongedekte cheques bij zich, en blijkt kwetsbaar als vrouw alleen in gezelschap van groepjes mannen.

Topaas' belevenissen op het eiland kunnen gedeeltelijk worden geïnterpreteerd als twintigste-eeuwse variaties op het Radcliffeaanse plot: een vrouw alleen moet haar onafhankelijkheid bevechten - al zijn in Noorderzon niet de afzonderlijke mannen, maar het collectief bedreigend. Toch gaat de meest wezenlijke spanning in Noorderzon mijns inziens niet over de worsteling om zelfstandigheid van vrouwen ten opzichte van mannen. Noorderzon gaat veeleer over de strijd om onafhankelijkheid van het noodlot. Topaas probeert zich van het Boze Oog te bevrijden, en ze probeert zich los te maken van de plicht die ze voelt om Lin Anemoon Savitra's onvoltooide leven te vervullen. Noorderzon gaat dus over de vraag of het mogelijk is je eigen leven te leiden, oftewel over individuele autonomie.

Die thematiek sluit aan bij de opvattingen van Nancy Armstrong, die romans leest in termen van de verhouding tussen individu en gemeenschap. De vraag is dan of het gotieke in Noorderzon een alternatief biedt voor modern individualisme en voor het 'natuurlijke' kerngezin als model voor de maatschappij.

Als ik Noorderzon lees vanuit Armstrongs perspectief, valt ineens op met hoeveel geweld het kerngezin in deze roman wordt bestreden. Topaas wil niet trouwen en ook geen kinderen krijgen. Julius' dagelijks werk als gynaecoloog bestaat niet uit het begeleiden van bevallingen maar uit het verwijderen van baarmoeders. De kinderen van het eiland zijn bijna allemaal doodgevroren. De laatste twee moeders die nog over zijn, zijn de slechte vrouwen van het eiland: kwade genius Flata, die drie volwassen, achterlijke zonen heeft, en de ijskoude Andrena, die de uitspraak doet 'om een kind is het me ten slotte niet te doen' (181). Zij vormt met haar broer Spider en hun mismaakte kind Wants een ontaard, incestueus kerngezin. Noorderzon heeft ook geen romantisch plot of huiselijk geluk in de aanbieding. Met onderhuurster Justine, die anders dan Topaas wel gevoel heeft voor romantiek, lijkt het gedoemd slecht af te lopen zodra ze voet zet op het eiland en Topaas' plaats inneemt. ${ }^{16}$

\footnotetext{
${ }^{16}$ Ook Haasse leest haar naam als omineus: '[T]e vrezen [valt] dat Justine niet voor niets de naam draagt van de gemaltraiteerde heldin uit een beruchte roman van de markies de Sade' (Haasse 2000, 289).
} 
Kortom, in Noorderzon vormt het kerngezin bepaald geen model voor de sociale orde. In die zin zou de roman een alternatief voor de Victoriaanse roman kunnen zijn in de zin van Armstrong. Maar worden via het gotieke alternatieve vormen van verwantschap verbeeld? Is er een ander model voor het collectief voorhanden?

Op het gotieke eiland wordt de gemeenschap bijeen gehouden door Flata, zelf ooit een buitenstaander. $\mathrm{Zij}$ heeft de eilanders in haar macht door ze een geheim te laten delen: na de dood van alle kinderen heeft zij de eilanders aangezet tot het plunderen van passerende schepen. Vóór Topaas' komst zijn vreemdelingen (Andrena en Spider, en Carebara) ingelijfd in de gemeenschap door ze deelgenoot te maken van het geheim. Flata heeft macht over de zielen van de eilanders doordat ze in spiritistische seances de geesten van de verdronkenen oproept en zo de schuldgevoelens van de eilanders sust. Maar ze is in een strijd om de macht verwikkeld met anderen die macht over de menselijke geest uitoefenen: namelijk met stoker Carebara en zijn alcohol, en met de abt die de absolutie kan verlenen.

Topaas komt naar het eiland om weer zichzelf te worden. Zolang ze de plaats van iemand anders wenst in te nemen (eerst die van Lin Anemoon Savitra, later die van Wants) is ze nog niet in staat om zichzelf te zijn, om een individu te zijn. Zij wil niet langer 'onder invloed' staan: ten eerste van de alcohol (ze was een stevige drinker, tijdens het ongeluk was ze dronken) en ten tweede van het Boze Oog. Topaas dient zich in haar streven te verhouden tot de gemeenschap van het eiland. Haar worsteling om een zelfstandig individu te worden, haar 'individualistic energy' in Armstrongs woorden, leidt uiteindelijk niet tot een verzoening tussen individu en gemeenschap, noch tot een inclusievere gemeenschap. Topaas wordt geen deel van de eilandgemeenschap. Aan het eind van de roman vliegt Topaas weg, niet langer gebonden aan wie of wat dan ook. Dat einde heeft iets onbevredigends; de roman eindigt in een aporie. Topaas is werkelijk vrij, maar de werkelijkheid voorbij. ${ }^{17}$

Noorderzon is daarmee eerder een bevestiging dan een ondermijning van de ideologie van het moderne individualisme. De vrijheid van het moderne indivi$\mathrm{du}$ - Topaas - wordt niet zozeer ingeperkt door het collectieve belang van de gemeenschap, maar door de grenzen van wat maakbaar is, door krachten die groter zijn dan het individu. Haar stem is een centraal motief in de roman, en

\footnotetext{
${ }^{17}$ Diverse recensenten vonden het echter bezwaarlijk dat Noorderzon zich 'volstrekt buiten de realiteit' (Breedt Bruyn 1986) afspeelde, of 'spijtig dat Dorrestein zo gemakkelijk een loopje neemt met de werkelijkheid' ('t Hart 1986).
} 
die stem is cruciaal voor Topaas' streven naar autonomie. Op de thematiek van de stem in Noorderzon ga ik nu dieper in.

\section{DE STEM VAN EEN VROUW}

Topaas is in eerste instantie alleen via haar stem aanwezig in Noorderzon. De lezer verneemt haar wederwaardigheden op het eiland via de cassettebandjes die ze ter plekke inspreekt en verstuurt aan Justine, die ze op haar beurt aan Julius laat horen. De cassettebandjes zijn een variatie op de structuur van de achttiende-eeuwse briefroman, de oervorm van de realistische roman. Die vertelstructuur wordt overigens niet de hele roman volgehouden. Stukken waarin Topaas de vertelinstantie is worden afgewisseld met stukken waarin een extradiëgetische verteller aan het woord is.

Het gebruik van bandjes, in plaats van brieven, benadrukt het belang van de stem. Van een stem, ook al is die opgenomen op een bandje, gaat een sterkere suggestie van aanwezigheid uit dan van een brief. ${ }^{18}$ Ten tweede benadrukken de bandjes het belang van moderne technologie. Het hanteren van de cassetterecorder wordt in de roman met enige nadruk beschreven: de knopen in het snoer, de stekker die niet past en Topaas' zorg over mogelijk lege batterijen. Aan de ontvangende kant worden de knopjes ingedrukt en wordt het bandje meermalen voor- en achteruit gespoeld.

De verteltechniek (briefroman) en -technologie (cassettebandjes) creëren een realistisch effect. De briefroman creëerde door het gebruik van lezers en schrijvers binnen de tekst en 'via de "writing to the moment"-techniek de illusie van directe weergave', zoals Aagje Swinnen schrijft (Swinnen 2006, 137). Noorderzon kent zijn eigen variant op de 'writing to the moment'-techniek, die het verhaal een extra realistische dimensie geeft, zoals wanneer Topaas zegt: 'Wacht even, Justine, het is net alsof ik iets geks hoor. Ach, het zal de wind zijn' (132). Topaas (in narratologische termen de intradiëgetische verteller) treedt op als surrogaatschrijver, die zich richt tot een surrogaatlezer/luisteraar: Justine (de intradiëgetische lezer). Daardoor wordt inderdaad de indruk gewekt dat de

\footnotetext{
${ }^{18}$ Katherine Hayles schrijft in dit verband: 'Long after writing dissociated presence from inscription, voice continued to imply a subject who was present in the moment and in the flesh. Audiotape was of course not the first technology to challenge this assumption, and the cultural work it did can best be understood in the context of related audio technologies, particularly telephone, radio and phonograph' (Hayles 1997, 76). Terwijl telefoon en radio de anwezigheid van de spreker op het moment van spreken veronderstellen (zij het op afstand), doorbreekt de bandrecorder ook de gelijktijdigheid. Niettemin is de illusie van directe weergave nog altijd groot, groter dan bij brieven; Hayles geeft daarvan diverse voorbeelden.
} 
bandjes een rechtstreeks verslag zijn van Topaas' ervaringen aan Justine. De lezer 'luistert mee' met de geadresseerde, Justine. Echter, alleen het eerste bandje dat Topaas inspreekt bereikt haar. Een tweede en derde bandje worden wel ingesproken, maar nooit verstuurd. Als lezer 'luister' je dan niet meer mee met Justine, bij het afspelen, maar 'luister' je naar Topaas bij het inspreken van de bandjes. Daardoor valt in de roman haast niet op dat bandje twee en drie niet verstuurd worden, en dat Justine als geadresseerde uit het verhaal verdwenen is. Dat interpreteer ik als een teken dat de lezer opgesloten raakt in Topaas' visie op de werkelijkheid, en dat Topaas het contact met haar leven thuis (de realiteit) verliest.

Voor Topaas fungeert het bandje als een documentair verslag, een soort dagboek. Het vertellen van haar ervaringen is voor haar een manier om (weer) controle te krijgen over haar leven: 'Misschien zou registratie enige helderheid brengen' (50). En elders denkt ze: 'Eigenlijk legde ze haar belevenissen voornamelijk voor zichzelf vast. Om er door ordening vat op te krijgen' (117). Er gaat echter steeds meer mis in de communicatie, wanneer Topaas geestelijk begint te ontsporen. Ik noemde al dat de bandjes hun ontvangeer niet meer bereiken. Op een gegeven moment spreekt Topaas niet meer haar cassetterecorder in, maar praat ze in een schelp: 'Aan wie dit hoort. Kom mij helpen.' (116). Vervolgens raakt ze haar stem kwijt, zodat communicatie via bandjes niet langer mogelijk is. Wanneer ze een gat in haar geheugen probeert te dichten, luistert ze naar haar eigen bandje, daarmee het onvermogen om een ander te bereiken illustrerend. Topaas spreekt en luistert alleen nog naar zichzelf, en daarmee is haar isolement compleet.

De ontvangers, Justine en Julius, hebben op hun beurt hun twijfels over het realistische gehalte van het vertelde en de authenticiteit van Topaas' woorden. Het bandje wekt hun irritatie, meer dan hun bezorgdheid over Topaas' plotselinge verdwijning. Justine zou bij voorkeur helemaal niets meer van Topaas willen horen - zij aast op het overnemen van Topaas' leven, in het bijzonder van haar minnaar Julius. Julius' waardering voor de eigenzinnigheid van zijn vriendin maakt snel plaats voor woede. Topaas lijkt niet in gevaar te zijn, en daarmee 'ontnam ze hem een rol in het geheel, de rol van redder bijvoorbeeld.' (48). Hij vindt het bandje 'bizar en beledigend' (48).

Een van Justines eerste reacties op Topaas' bandje is: 'Ze maakte er weer een compleet hoorspel van' (18). Topaas lijkt zich bewust van dit fictionele effect van haar bandopname: 'Toen hoorde ik een deur slaan, gevolgd door het geluid van voetstappen. Klassieke effecten, Justine.' (131). Justines twijfel is niet zo verwonderlijk, want voordat Topaas haar leven ontvluchtte was ze hoofd dramaturgie bij de radio, verantwoordelijk voor de hoorspelen. Topaas verzint dus 
beroepshalve verhalen. Topaas is in haar element, ze is haar eigen professionele zelf op haar bandjes. Precies dat veroorzaakt irritatie bij haar luisteraars: zij verwachten een egodocument, maar vinden Topaas' relaas meer lijken op een hoorspel. Ook de lezer kan gewaarschuwd zijn, want Topaas' motto is: 'De werkelijkheid? Houd toch op. Vertel me liever een goed verhaal.' (8). Is er nog wel onderscheid tussen wat 'echt' is en wat niet? De bandjes hebben geen unheimlich effect op de luisteraars Julius en Justine: ze worden niet bang van de vreemde avonturen die Topaas vertelt. Ze beschouwen de bandjes als een hoorspel: een fictionele ruimte is waar zintuiglijk bedrog tot de afspraak behoort. Als de luisteraar die 'afspraak' honoreert en zich wil laten bedriegen is er niets aan de hand.

Op een ander punt is wel sprake van een unheimlich effect. Er zijn aanwijzingen dat Topaas' perspectief ook dat van de externe (extra-diëgetische) verteller gaat domineren, naarmate de roman vordert. Dit valt te illustreren aan de hand van het moment dat Julius probeert vast te stellen wanneer Topaas' belevenissen nu precies hebben plaatsgevonden. Hij komt tot de ontdekking dat hij zich een hele week vergist heeft:

Een hele week, zou Julius, op een ander tijdstip, een andere plaats, plotseling denken. Hij vergiste zich een hele week: niet alleen had Topaas' bandje er volgens het poststempel een week over gedaan om hem te bereiken, het was op het moment van posten natuurlijk al een week oud geweest, aangezien die veerboot niet vaker ging. Julius zou het op zijn plek in de tijd en de ruimte nog een keer helemaal beluisteren. De wetenschap dat Topaas op haar plek op dat moment al twee weken op hem was uitgelopen, zou hem met een griezelig gevoel van incongruentie vervullen. (82)

Het 'griezelig gevoel van incongruentie' is een unheimlich gevoel: de verwarrende en enigszins vreeswekkende ervaring dat de realiteit niet is zoals verwacht. De manier waarop deze alinea, en met name de laatste zin van dit citaat is geformuleerd, zaait echter twijfels over wie hier precies focaliseert - Julius of Topaas. De alinea zit ingeklemd tussen twee lange fragmenten waarin Topaas focaliseert (maar niet vertelt). Vlak voor de hierboven geciteerde passage staat de zin: 'Dat ergens nog zoiets als thuis bestond was haar de laatste dagen geheel ontschoten' (82). Die zin wekt sterk de suggestie dat wat volgt in feite Topaas' gedachten zijn, en niet die van Julius. Ook de formulering van de laatste zin van het citaat is ambivalent, door het gebruik van 'zou' enerzijds (wat past bij focalisatie door Topaas), en de eigennaam 'Topaas' anderzijds (wat past bij focalisatie door 
Julius). ${ }^{19}$ We zouden even goed te maken kunnen hebben met Topaas' fantasie over Julius' reactie. Dat zou betekenen dat Topaas in staat is Julius' reactie te focaliseren. Dat wekt de veronderstelling dat de extradiëgetische verteller (de verteller van zinnen als: 'Dat ergens nog zoiets als thuis bestond' en 'De wetenschap dat Topaas op haar plek...') de focalisatie afstaat aan Topaas, ook in scènes waarin zij niet voorkomt. ${ }^{20}$ Met andere woorden, het is onmogelijk om een duidelijk onderscheid te maken tussen de (verhaal)werkelijkheid en de verbeelding van Topaas. We kunnen moeilijk nog spreken over een reactie van Julius.

Ook als Topaas niet meer rechtstreeks aan het woord is als vertelinstantie, focaliseert ze nog. De schijnbaar afstandelijke (extra-diëgetische) verteller is met andere woorden niet per se betrouwbaar. Als Topaas ook Julius' reactie kan focaliseren kan de conclusie haast niet anders zijn dan dat zij samenvalt met die extra-diëgetische verteller, al is dat formeel onmogelijk. Aan het eind van de roman wordt die vermenging van niveaus nog eens geëxpliciteerd, als Justine en Julius met de veerboot arriveren op het eiland: '[ze] maakten [...] een misplaatste indruk, alsof ze inderdaad door de kracht van Topaas' wens uit hun gewone bezigheden waren weggerukt en, zonder te beseffen wat er gebeurde, op de veerpont waren neergesmeten' (188). ${ }^{21}$ Er wordt in Noorderzon dus verwarring gezaaid over het werkelijkheidsgehalte van het bandje (bij Julius en Justine), en over wie er aan het woord is (bij de lezer).

Topaas is een vrouw met een professionele stem - als hoorspeldramaturg. Haar stem is het middel om haar leven weer op de rails te krijgen, maar juist dat gereedschap raakt ze kwijt, na de dood van de doofstomme Wants. Zij had hem onder haar hoede genomen om haar schuld aan Lin te delgen, maar hij sterft in

\footnotetext{
${ }^{19}$ Vergelijk de oorspronkelijke zin (o) met de volgende varianten:

(o) 'De wetenschap dat Topaas [...] op hem was uitgelopen, zou hem met een griezelig gevoel van incongruentie vervullen.'

(1) 'De wetenschap dat Topaas [...] op hem was uitgelopen, vervulde hem met een griezelig gevoel van incongruentie'. In dit geval ligt de focalisatie bij Julius.

(2) 'De wetenschap dat zij [...] op hem was uitgelopen, zou hem met een griezelig gevoel van incongruentie vervullen'. Nu ligt de focalisatie bij Topaas - die verwijst naar zichzelf als 'zij', en stelt zich voor hoe Julius zou reageren.

${ }^{20}$ Formeel zou dat volgens de structuralistische narratologie niet mogelijk zijn, maar een postklassieke narratologie heeft daar minder moeite mee. Zie Herman en Vervaeck (2002), p. 93 en hoofdstuk 3.

${ }^{21}$ Ook op het eiland wordt openlijk getwijfeld aan Topaas' waarnemingen: Spider en Andrena reageren blanco als Topaas vertelt dat ze hen in een seksuele orgie heeft gezien. 'Wat een nachtmerrie', reageert Andrena (142).
} 
haar aanwezigheid. ${ }^{22}$ Topaas scheert dan haar hoofd kaal - waardoor er een fysieke gelijkenis tussen Wants en haar ontstaat. Juist op dat moment meent ze dat ze door Andrena vervloekt wordt - zoals Wants eerder door Andrena is vervloekt -, en kan ze geen woord meer uitbrengen: 'In plaats van iemand die sprak, zou ze voortaan iemand zijn die zweeg. Was ze van iets dat zwom geworden tot iets dat zweefde, dan was de metamorfose niet groter geweest' (149).

De cultuurwetenschapper Katherine Hayles stelt dat er instabiliteit ontstaat wanneer 'voices are taken out of bodies and bodies find themselves out of voices' (Hayles 1997, 75); subjectiviteit wordt dan gefragmenteerd en 'riven by disconcerting metamorphoses' (Hayles 1997, 75). ${ }^{23}$ De verontrustende metamorfose die Noorderzon presenteert is Topaas' verandering in Wants. Uiteindelijk verandert ze nog verder, in een vogel of een engel. Ze krijgt daadwerkelijk vleugels, en uiteindelijk vliegt ze weg, het verhaal uit - waarschijnlijk, want hoe zouden we het zeker kunnen weten? Topaas kan het ook verzonnen hebben.

Topaas' autonomie wordt gesymboliseerd door haar stem. Ik denk dat we die stem niet moeten verwarren met de vrouwelijke stem waar Armstrong aan refereert. Die stem, van de madwoman in the attic, symboliseert de uitgesloten en machteloze positie van vrouwen. Topaas' professionele stem is een bron van retorische macht die veel groter is dan die van de madwoman: ze geeft er letterlijk de werkelijkheid mee vorm. Haar stem is bovendien juist een symbool van economische onafhankelijkheid, die haar gelijkwaardigheid ten opzichte van Julius bevordert.

Gaandeweg begint Topaas te ontsporen, en verandert ze in een soort madwoman, zoals ik beschreef. Dan verliest ze het contact met haar luisteraars en tenslotte zelfs haar stem. Dat symboliseert echter niet haar machteloosheid als vrouw. Paradoxaal genoeg is het verlies van haar stem uiteindelijk bevrijdend voor Topaas: daardoor komt ze in het reine met zichzelf. Het verlies van haar professionele gereedschap, het middel waarmee ze haar autonomie trachtte te herwinnen, betekent dat ze onder ogen moet zien dat haar macht om de gebeurtenissen te beïnvloeden beperkt is - en was. Ze had Lins dood niet kunnen voorkomen, hoe groot haar verbeeldingskracht ook was: 'Er waren doofstommen die Mendelssohn floten. Niets was onmogelijk. Behalve haar Boze Oog

\footnotetext{
${ }^{22}$ Van de toedracht van zijn dood bestaan twee versies: volgens Topaas is Wants doodgeschoten door zijn ouders Spider en Andrena; in de versie van de eilanders heeft Topaas Wants in het ravijn geduwd.

${ }^{23}$ Hayles schrijft over de verontrustende metamorfoses die geluidsband kan produceren, in een roman over (en experimenten met) bandrecorders van de Amerikaanse auteur William S. Burroughs, The Ticket that Exploded (1967). De verontrustende metamorfoses zijn bij Burroughs de stemmen-op-band die lichamen kunnen transformeren.
} 
dienstig maken aan haar eigen doeleinden [...]. Dat haar Boze Oog dus onmogelijk kon bestaan was de enig logische gevolgtrekking. Ze had nooit naar het eiland hoeven komen.' (173-174). Topaas' geloof in het Boze Oog is een gotiek element dat zich laat verbinden met de ideeën van Nancy Armstrong over individuele autonomie en gemeenschap. Over het Boze Oog gaat de volgende paragraaf.

\section{HET BOZE OOG}

Topaas worstelt sinds het fatale ongeluk met een schuldgevoel. Ze begrijpt niet 'hoe [...] je kwaad [kunt] aanrichten als je intenties niet slecht zijn' (11). Deugdzaamheid zou met andere woorden tot het goede moeten leiden, maar dit morele wereldbeeld valt niet vol te houden na het ongeluk: Lin is immers dood terwijl Topaas goede bedoelingen had. Topaas ruilt daarop een morele opvatting van het kwaad (slecht handelen als de oorzaak van het kwaad) in voor een metafysische (het Kwaad heeft een bovennatuurlijke oorsprong): ze raakt ervan overtuigd dat ze is getroffen door het Boze Oog. Ze wordt in die overtuiging gesterkt wanneer een gans, een konijn en de jongen Wants in haar aanwezigheid sterven. Het geloof in het Boze Oog biedt een uitweg uit het falen van het morele wereldbeeld. Door haar individuele autonomie in te ruilen voor de hogere macht van het Boze Oog kan ze zich ontslagen voelen van haar schuld. ${ }^{24}$

Het Boze Oog kent in het volksgeloof twee vormen: 'one voluntary, moral Evil Eye inspired by malice; the other involuntary, the natural Evil Eye, a feature over which the unfortunate possessor has no control.' (Ayers 2003, 106). Topaas beschouwt zichzelf als een slachtoffer, getroffen door de tweede variant, het onwillekeurige Boze Oog. Topaas wil haar bovennatuurlijke Boze Oog bestrijden door een al even metafysisch geïnspireerd ritueel, dat alleen kan plaatsvinden buiten de moderne wereld, op het gotieke eiland.

Ze reist af naar het eiland omdat ze haar hoop heeft gevestigd op zuivering via een katholiek ritueel: biecht en vergeving. De abdij van het eiland is legendarisch, maar het religieuze instituut blijkt door en door corrupt. De abt wordt in permanente staat van dronkenschap gehouden door de stoker, die zijn whisky

\footnotetext{
${ }^{24}$ Dit falen van een moreel wereldbeeld wordt nog eens benadrukt door een mise en abyme in Noorderzon. Topaas leest de memoires van ene Anna Henker, die ze wil bewerken tot hoorspel. Deze echtgenote van een nazi-commandant houdt zichzelf voor dat het niet aan haar is om haar mans belangrijke werk in de gaskamers in de weg te staan. Topaas realiseert zich dat Anna Henkers goede bedoelingen verschrikkelijke gevolgen hadden. 'Henker' betekent 'beul' in het Duits (met dank aan Kathrin Lang).
} 
stookt binnen de muren van de abdij en feitelijk de macht heeft. Topaas' biecht neemt daardoor groteske vormen aan. Als de abt even uit zijn sluimer ontwaakt kreunt hij: 'Stoker? Heb ik iets gemist? Is het al tijd om haar zonden te vergeven?' (68). De drie aanwezige monniken geven zich over aan piraterij en smokkel, en in het klooster worden drinkgelagen en seksorgies gehouden.

Het kwaad zit evenwel nog dieper: de abdij is gerestaureerd met geld van een mosterdgasfabrikant. En nog dieper blijkt het kwaad te zitten: het ligt zelfs aan de basis van het geloof waar de abdij voor staat. Topaas hoort namelijk een verhaal over de verkrachting van een boerenmeid door een Romeinse soldaat. De bastaardzoon die hieruit voortkwam zou Pontius Pilatus zijn geweest, de stadhouder die Jezus ter dood veroordeelde. De stoker - die met succes in Topaas' stellige overtuigingen pookt - houdt haar voor dat Pilatus de mensheid tot heil heeft gestrekt met die slechte daad, want zonder hem was er geen christendom geweest. Een verkrachting was dus cruciaal voor het geloof dat haar moet redden. Topaas is bang dat ze niet meer van haar Boze Oog afkomt als de katholieke route van de biecht blijkt afgesneden. Bovendien vreest ze dat de eilanders haar zullen zien en herkennen als medium van het Kwaad.

Topaas' geloof in het Boze Oog is een gotiek element. Het is een voorbeeld van een premodern bijgeloof dat plotseling opduikt in het moderne bestaan. Sigmund Freud, die zich met dit thema heeft beziggehouden, noemt de plotselinge terugkeer van ideeën die in diskrediet zijn een bron van het Unheimliche. ${ }^{25}$ Met het Unheimliche doelt Freud op een (milde) angst die zich kan manifesteren in kunst en werkelijkheid, en die uiteenlopende fenomenen omvat als dubbelgangers, vreemde herhalingen en magisch denken. ${ }^{26}$ Het Unheimliche wordt algemeen als onderdeel van het gotieke repertoire beschouwd, niet alleen door diegenen die het gotieke psychoanalytisch willen duiden. ${ }^{27}$ Freud interpreteert de angst vooral symbolisch. Unheimlich is volgens hem het vertrouwde (het heimliche) dat in zijn tegendeel verkeert, dat ons vreemd geworden is door ver-

\footnotetext{
${ }^{25}$ Het Unheimliche werd voor het eerst door de psychiater Ernst Jentsch (1906) besproken, maar is vooral door Freud (1919) beroemd geworden Voor een goed overzicht van de ontwikkeling van het Unheimliche van fenomeen tot concept, en het gebruik ervan in hedendaagse literatuurwetenschap, zie Masschelein (2003).

${ }^{26}$ Volgens Jentsch wordt het Unheimliche veroorzaakt door de onzekerheid ('intellektuellen Unsicherheit') die ons kan overvallen bij het onderscheiden van het levende (bezielde) en het levenloze. In Jentsch' woorden is het Unheimliche: 'Zweifel an der Beseelung eines anscheinend lebendigen Wesens und umgekehrt darüber, ob ein lebloser Gegenstand nicht etwa beseelt sei' (Jentsch geciteerd in Freud 1989, 250). Een wassen beeld, of een mechanische pop kan bijvoorbeeld zo'n unheimliche ervaring teweegbrengen - een moment lang weten we niet zeker of we een levend mens voor ons hebben of niet.

${ }^{27}$ Zie bijvoorbeeld Punter \& Byron (2004), 283-288; Punter (2007), 129-137.
} 
dringing. ${ }^{28}$ Een kleine categorie unheimliche ervaringen draait volgens Freud om een vorm van 'Realitätsprüfung' (Freud 1989, 270), het toetsen van de werkelijkheid, zoals wanneer je je eigen spiegelbeeld even voor iemand anders aanziet, of als plotseling een in diskrediet geraakt (bij)geloof terugkeert. Het Boze Oog noemt Freud als voorbeeld van die tweede categorie: 'Eine der unheimlichsten und verbreitetsten Formen des Aberglaubens ist die Angst vor dem "bösen Blick"' (Freud 1989, 262).

Literatuurwetenschapper Adam Frank (2007) stelt in een hernieuwde lezing van het Unheimliche de door Freud genoemde angst om de ogen te verliezen centraal. ${ }^{29}$ Het Unheimliche wordt volgens Frank veroorzaakt door de blokkering van een uitwisseling van affect. Het is in wezen een mislukte poging tot contact, een vorm van gefnuikte communicatie. Het is unheimlich wanneer een blik niet wordt beantwoord terwijl we dat wel verwachten, volgens Frank, zoals wanneer we naar iets kijken dat wel ogen heeft maar niet terug kan kijken, zoals een pop, of een foto. Het gevoel door de eigen zintuigen bedrogen te worden is volgens Frank te vergelijken met 'the idea of being robbed of one's eyes' (Frank 2007, 517). Frank gebruikt de theorieën over kijken van de psycholoog Silvan Tomkins, die ook over het Boze Oog schrijft: 'The evil eye, for Tomkins, is an expression of the[se] taboos on looking and the fears associated especially with the escalation of humiliation, anger and fear' (Frank 2007, 517). ${ }^{30}$ Het Boze Oog is volgens Tomkins net als voor Frank unheimlich omdat het door zijn

\footnotetext{
${ }^{28}$ De belangrijkste bron van het Unheimliche is de terugkeer van een verdrongen castratieangst, zo concludeert Freud op grond van een interpretatie van E.T.A. Hoffmanns Der Sandmann De castratieangst manifesteert zich in dat verhaal als de angst om 'die Augen zu beschädigen oder zu verlieren' (Freud 1989, 254), want droomduiding heeft ons volgens Freud geleerd 'dass die Angst um die Augen, die Angst zu erblinden, häufig genug ein Ersatz für die Kastrationsangst ist' (Freud 1989, 254).

${ }^{29}$ Frank plaatst de bron van het Unheimliche dus, in navolging van Stanley Cavell, in het toetsen van de werkelijkheid - net als Jentsch, en ook net als Freud in zijn tweede categorie, zie Cavell (1988), p. 155. Ook Scharpé (2003) vindt de lezing van het Unheimliche als verdrongen castratiecomplex niet overtuigend; hij stelt voor om Jentsch' oorspronkelijke idee - het Unheimliche als 'intellektuele Unsicherheit' - an te houden.

${ }^{30}$ Tomkins (1963) vervangt de seksuele taboes van de psychoanalyse door een andere set taboes: op kijken, op aangekeken worden en op uitgewisselde blikken. Hij herinterpreteert zelfs de Oedipusmythe in deze termen, en concludeert dat de straf die Oedipus ontvangt (uitgestoken ogen) past bij de overtreding die hij begaat: Oedipus werpt getaboeïseerde blikken op zijn moeder. Oedipus wordt dus niet gestraft omdat hij een seksueel taboe breekt, maar een taboe op kijken (Tomkins 1963, 177).
} 
dodelijke werking (de 'de-animating quality of looking') een blokkering van de uitwisseling van affect bewerkstelligt. ${ }^{31}$

Franks herinterpretatie van het Unheimliche is interessant voor de interpretatie van Noorderzon, omdat daarin, behalve over het Boze Oog, een steeds terugkerend verhaal over het verlies van ogen wordt verteld. Het gaat over een vrouw die vóór Topaas het eiland bezocht: ze werd verkracht, of vermoord, of vloog weg op een steen of als een vogel, afhankelijk van de versie die wordt verteld. Topaas hoort steeds een nieuwe versie, maar 'de afloop is altijd hetzelfde' $(82,170)$. Ze voelt dat het verhaal een waarschuwing aan haar is - ook een vrouw alleen, ook in spijkerbroek, een vreemdeling op het eiland. In elke versie van het verhaal verliest de vrouw haar ogen: nu eens omdat die uitgepikt worden door de meeuwen, dan weer omdat zij ze zelf uitrukt. Dit verhaal, dat gemedieerd wordt door verschillende eilanders, maar nooit exact gereproduceerd, heeft door de herhalingen een unheimlich effect.

Het verhaal over de vrouw die haar ogen uitrukt is een variatie op de legende over de katholieke heilige Lucia, beschermheilige van de blinden. In een van de over haar bekende legenden rukte zij zich de ogen uit, toen een aanbidder haar mooie ogen prees, om haar kuisheid te bewaren. ${ }^{32}$ Zo gaat het ook in een van de versies die Noorderzon presenteert:

"Waarom laten jullie me niet met rust?" schreeuwde zij [...] Iemand zei: "Omdat je ogen zo schoon zijn". En toen - toen sprong zij op en rukte ze zich de ogen uit het hoofd en wierp ze aan zijn voeten. Ze gooide ze gewoon op de grond! Ik mag doodvallen als het niet waar is. "Hier heb je mijn schone ogen," riep ze en begon te hollen. (17)

De vrouw weigert nog langer object van begeerte te zijn. Ze rukt haar ogen uit en vervult daarmee de omstanders met afschuw. Dit verhaal is, net als het geloof in het Boze Oog, een uitdrukking van het taboe op kijken. Volgens Tomkins ontstaat zo'n taboe overal waar een verbod op intimiteit, seksualiteit en affect bestaat: 'To the extent to which intimacy, sexuality and affect necessarily suffer

\footnotetext{
${ }^{31}$ Dat dit bijgeloof als premodern wordt beschouwd moge nog eens blijken uit Tomkins' woordkeus: 'Even in modern times, in Western Europe, public figures have been feared because of their evil eye' (Tomkins 1963, 165, mijn cursivering).

32 Lucia komt voor in Dantes Divina Commedia. De Amerikaanse vertaler van Dante, Mark Musa, schrijft: 'According to legend, St. Lucy of Syracuse plucked out her beautiful eyes when they were admired by an importunate suitor. For this incomparable act of chastity she was rewarded with even more beautiful eyes and became the patroness of those suffering from impaired vision.' (Musa 1996, 97).
} 
inhibition, there will inevitably appear taboos on interocular intimacy.' (Tomkins 1963, 183). Tomkins bespreekt niet de genderimplicaties van het taboe op kijken. Hoewel hij wel opmerkt dat vrouwen vaker worden beschuldigd van het Boze Oog (Tomkins 1963, 167), trekt hij niet de conclusie dat voor vrouwen het taboe op kijken kennelijk groter is dan voor mannen. In dit verhaal in Noorderzon, net als in het verhaal over de heilige Lucia, wordt het taboe op de seksueel geladen blik doorbroken: de mannen staren de vrouw onbeschaamd aan. Haar antwoord op deze doorbreking is rigoureus. Door zich de ogen uit het hoofd te rukken verbreekt ze de communicatie van (ongewenst) affect, en maakt zo het taboe zichtbaar. Door haar begerenswaardigheid teniet te doen behoudt ze haar vrijheid, zij het tegen een hoge prijs: het verlies van haar ogen.

Topaas wil van haar oog/ogen beroofd worden - haar Boze Oog wel te verstaan. In die zin lijkt ze op de heilige Lucia, die ook haar ogen wil verliezen en ze ten slotte eigenhandig uitrukt. Maar Topaas verliest in eerste instantie niet haar Boze Oog, maar haar stem; niet de magische kracht van haar Boze Oog, maar 'de magische krachten van het woord' $(45,148,189)$, zoals het herhaaldelijk heet. Eerder in de roman heeft ze echter uitgelegd wat de verbindende schakel is tussen het visuele en het auditieve: dat is het hoorspel - en laat dat nu juist Topaas' specialisme zijn. Het hoorspel verbindt oor en oog, want het is in staat beelden te creëren via het oor, zo legt Topaas uit aan Spider:

Ik mag graag uitleggen wat zo fascinerend is aan het fenomeen dat hoorspel heet. Voor mij is het voornaamste punt, dat de werkelijkheid van het hoorspel strikt fictioneel is. Woorden en klanken duiden situaties aan, die pas in de verbeelding van de luisteraars zichtbaar worden. Via het oor zien zij gebeurtenissen. (34) $)^{33}$

Dit is de magische kracht van het woord: geluid in beeld veranderen, oor in oog. Het hoorspel is in feite een vorm van afgesproken zintuiglijk bedrog: “ $[\mathrm{H}]$ et $[\mathrm{is}]$ nogal gek [...] dat je zintuigen je zo kunnen bedotten. Je denkt altijd dat ze niet kunnen liegen, alleen maar registreren. In die zin gebruik je ze tenslotte ook de hele dag om de werkelijkheid te toetsen en te onderzoeken."' (35). Het hoorspel is een fictionele ruimte waarin het unheimliche aspect van het toetsen van de werkelijkheid, de Realitätsprüfung, even buitenspel wordt gezet. Spider gaat nog een stapje verder: "'Ik denk niet dat de werkelijkheid ooit getoetst kan worden," zei Spider. "Aangezien die immers evenzeer wordt voort-

\footnotetext{
${ }^{33}$ Een opvallende overeenkomst met wat de verteller in Burroughs' The Ticket that exploded beweert: 'What we see is dictated by what we hear' (geciteerd in Hayles 1997, 93).
} 
gestuwd door wat we denken en geloven als door wat er echt plaatsvindt. Hoe kun je ooit bepalen of iets gedroomd of gebeurd is?"' (35). Topaas is enthousiast, want ze treft niet vaak iemand die net zo over die dingen denkt als zij, maar ze brengt het gesprek terug op het hoorspel: 'wat je als hoorspelmaker dus doet, is impulsen uitzenden die illusies opwekken. Illusies die voor iedereen verschillend zijn.' (35).

Topaas probeert eerst van haar metafysische Boze Oog af te komen door een metafysisch (katholiek) ritueel. Dat mislukt omdat het katholieke instituut zelf blijkt te wortelen in het kwaad. Vervolgens probeert ze zichzelf te bevrijden via de transformerende kracht van het hoorspel: door haar werkelijkheid zelf vorm te geven. Ook dat lukt haar niet. Ze raakt het (geloof in het) Boze Oog pas kwijt als ze van haar stem beroofd is, als ze niet meer kan vertellen. Pas dan zijn haar ogen weer haar eigen ogen:

Ze probeerde zich te herinneren waarom ze ook weer naar het eiland was gekomen. Het had iets te maken met het verlangen, zichzelf recht in de ogen te kunnen blijven zien. Zonder hoop of vrees boog ze zich over het spiegelende wateroppervlak. Ze keek diep in het eiland dat zo raadselachtig zijn goede krachten voor kwade had verloren. Toen zag ze dat het haar eigen ogen waren waarin ze staarde. Er gebeurde niets. Het was geen kunst om zichzelf recht aan te blijven kijken. (177)

Topaas moet de banaliteit van het lot en haar eigen onbeduidendheid accepteren, wat in Noorderzon wordt aangeduid als de 'wet van Pontius Pilatus': '[er] is [...] geen relatie tussen iemands bedoelingen en de uitkomst van zijn handelen.' (69). Uiteindelijk accepteert Topaas haar eigen onmacht. Ze maakt die verandering door (ze verandert letterlijk, in een wezen met vleugels), als ze de macht over het verhaal - de 'magische krachten van het woord' - noodgedwongen uit handen heeft gegeven. Topaas verandert in een vogel. Zo lijkt ze de vrouw te worden uit het verhaal dat ze niet zelf vertelt, maar hoort.

In Noorderzon wordt een individueel-ethisch wereldbeeld van deugdzaam handelen geconfronteerd met een metafysisch wereldbeeld. Het metafysische Kwaad kan niet worden overwonnen met een beroep op het katholieke geloof. In die zin lijkt Noorderzon een seculier wereldbeeld te huldigen, al komt het katholieke geloof via de achterdeur - de legende van de heilige Lucia - weer binnen. Dat verhaal is machtiger dan Topaas' eigen verhaal en haar geloof in de kracht van fictie. Het gotieke in deze twintigste-eeuwse roman draait om de grenzen aan de individuele maakbaarheid - morele deugdzaamheid kan het kwaad niet voorkomen en de macht van de verteller/schrijver is niet groot ge- 
noeg om het kwaad af te wenden. Noorderzon gaat over individuele autonomie. Niet een exclusief vrouwelijke autonomie, al worden de gegenderde aspecten van het kwaad wel aangeroerd via de Lucia-legende en het Boze Oog.

Het geloof in het Boze Oog is niet alleen Topaas' antwoord op het falen van een moreel wereldbeeld, maar ook haar manier om aan een conventioneel vrouwenleven te ontsnappen. De stoker Carebara weet feilloos de vinger te leggen op het verband tussen Topaas' veronderstelde Boze Oog en het feit dat ze niet wil trouwen:

"Wel", zei Carebara, "het zou natuurlijk kunnen dat je een excuus wenste om aan zo'n vanzelfsprekend leven [= een huwelijk, AA] te ontkomen. Dat Boze Oog, zoals je het noemt, is een hele uitkomst." "Ik moet zeggen dat ik hier geen weerwoord op heb", zei ze woedend. (67)

Voor het eerst is Topaas letterlijk sprakeloos - dat overkomt haar niet weer totdat ze echt haar stem verliest. Ze wordt door sprakeloosheid getroffen op het moment dat het gaat het over het traditionele (vrouwen)leven. Haar professionele stem heeft haar behoed voor zo'n leven, maar heeft haar ook verstrikt in een net van verzinsels (zoals het Boze Oog). Topaas' stem bergt de ambiguïteiten in zich tussen beroepsmatig vertellen en persoonlijk verslag doen, tussen waargebeurd en verzonnen.

Noorderzon presenteert allereerst een contrast tussen het gotieke eiland en de moderne Topaas. De belangrijkste functie van het gotieke in deze roman ligt echter niet in het ensceneren van de spanningen tussen vrouwelijk individu en patriarchale orde, zo heb ik betoogd. Via het gotieke element van het Boze Oog wordt een andere spanning meer centraal gesteld: die tussen de maakbaarheid van het lot en de banaliteit van het lot, tussen individuele autonomie en overmacht. Zoals de heilige Lucia door het verlies van haar ogen haar onafhankelijkheid behoudt, zo vindt Topaas zichzelf terug door het verlies van haar stem.

De thematiek van de vrouwelijke stem komt ook naar voren in Perpetuum mobile, dat in de rest van dit hoofdstuk centraal staat. De metafoor van 'een eigen stem vinden', die Armstrong aanwees als de centrale beeldspraak van de tweede feministische golf, structureert Perpetuum mobile. Ook de verhouding tussen individu en gemeenschap en tussen feminisme en Victoriaanse roman spelen een belangrijke rol. Hoe verhouden Dorresteins feministische stellingnames in dit boek zich tot de narratieve strategieën die ze hanteert, of in andere bewoordingen: hoe verhoudt Dorresteins emancipatoire inzet zich tot het gotieke? 
Perpetuum mobile (1988) is een hybride boek: een mengeling van autobiografie, roman en feministisch pamflet. Het is een persoonlijk verslag van Dorresteins pijnlijke verhouding met haar zusje dat zelfmoord pleegde, maar bevat ook verhalende elementen en fictieve personages. Het is een maatschappelijke aanklacht tegen de onderdrukking van vrouwen en vormt een reflectie op Dorresteins schrijven en de ontvangst van haar romans tot dan toe. Perpetuum mobile is dus geen 'gewone' gotieke roman, maar bevat wel een aantal gotieke elementen. Zo wordt het personage Godelieve Ochtendster vergeleken met het monster van Frankenstein, en vergelijkt verteller Renate ${ }^{34}$ zichzelf herhaaldelijk met een vampier. Aan het eind van het boek roept zij ene dokter Kaplan uit New York aan, 'hoofd van 's werelds enige Vampire Research Centre' (140). ${ }^{35}$ Verder is er de al eerder aangehaalde verwijzing naar het genre van de gothic novel, die 'niet voor niets door vrouwen groot is gemaakt' (102).

Perpetuum mobile gaat over zusterschap, over het verlies van een zus en over de rivaliteit tussen zussen. Zo is het boek meestal gelezen: als een autobiografische (sleutel)roman over Renate Dorrestein en haar zusje. Het gaat echter niet alleen over de relatie tussen deze twee zussen, maar ook over de verhoudingen in de vrouwenbeweging. Mijn stelling is dat Dorrestein in Perpetuum mobile het voor de vrouwenbeweging lastige thema van de rivaliteit tussen feministische vrouwen onderzoekt via het verhaal over Renate en haar zusje. Perpetuum mobile laat zich lezen als een stellingname in het feministische debat over de vrouwelijke stem en als een commentaar avant la lettre op de ideeën van Nancy Armstrong. De verhoudingen tussen individu(en) en gemeenschap worden namelijk met gotieke middelen vormgegeven.

Het streven naar autonomie voor vrouwen is een belangrijk thema in Perpetuum mobile: de autonomie van Renate, die van haar zusje, en die van vrouwen in het algemeen. Renate gaat tekeer tegen de 'liehiefde', zoals het consequent staat geschreven, 'de romantische, en de familiale die daar meestal het gevolg

\footnotetext{
${ }^{34}$ Renate deelt een aantal kenmerken met wat bekend is over de echte Renate Dorrestein, zoals haar leeftijd, beschrijving van het eerdere werk, haar werk als medewerker van $O_{p z i j}$, haar verblijf in de VS als writer in residence. Om het onderscheid tussen de vertelinstantie en de auteur helder te houden duid ik de verteller aan als Renate en de auteur als Dorrestein. Zie ook Van Heijst (1993), p. 91.

${ }^{35}$ Er zijn inderdaad twee titels bekend van een zekere Stephen Kaplan: In Pursuit of Premature Gods and Contemporary Vampires (Long Island, New York: Vampire Research Centre, 1976) en Vampires Are (ETCC publications, 1984).
} 
van is' (14). Die 'liehiefde' maakt vrouwen tot 'hoedsters en voedsters' van mannen en kinderen, sluit hen op in het kerngezin en ontzegt hun een eigen leven. De dood van Renates zusje lijkt de pijnlijkste onderstreping van die ideologie van de 'liehiefde'. Zij leed onder de (schoonheids)eisen die aan vrouwen gesteld worden: zij had boulimia. $\mathrm{Zij}$ is echter niet alleen maar slachtoffer van de omstandigheden. Annelies van Heijst (1993) stelt in haar uitgebreide interpretatie van Perpetuum mobile dat de feministische maatschappijkritiek niet als eenduidig verklaringsmodel fungeert voor alle ellende. Het zusje wordt als individu niet totaal gedetermineerd door de patriarchale maatschappij, maar houdt een 'onherleidbare eigenheid en een geheim' (Van Heijst 1993, 101).

Dan is er de autonomie van Renate, die verlost wil worden van haar schuldgevoel over haar zusjes dood. Haar vrijheid van handelen blijkt begrensd. Zij komt uiteindelijk tot de conclusie dat zij geen schuld heeft, omdat zij het leven van haar zusje niet kon redden. Er zijn grenzen aan wat het individu vermag. De thematische overeenkomsten met Noorderzon zijn duidelijk: ook Topaas lijdt aan schuldgevoel - over Lins dood - en loopt tegen de grenzen aan van de individuele autonomie. Topaas en Renate weten zich op vergelijkbare wijze van hun schuldgevoel te bevrijden: doordat ze enerzijds tot het besef komen dat hun macht om de loop der dingen te beïnvloeden beperkt is, en er anderzijds in slagen om hun zelfstandigheid als individu - ten opzicht van de dode - te herwinnen.

Door Renates relaas over haar zusje zijn twee andere verhalen geweven waarin ook (het gebrek aan) autonomie van vrouwen wordt gethematiseerd, over buurvrouw Lydia en over Godelieve Ochtendster. Elk op hun eigen manier worden Lydia en Godelieve slachtoffer van de positie die aan vrouwen is toebedeeld in het perpetuum mobile van de liehiefde. Lydia verliest haar hart aan een man die een vrouw zonder hoofd wenst. In haar pogingen hem te behagen en van dienst te zijn gaat ze zover, dat ze letterlijk gek wordt - haar hoofd verliest en tijdelijk achter de muren van een psychiatrische inrichting verdwijnt. Godelieve ontsnapt in eerste instantie nog aan het perpetuum mobile van de liefde doordat ze zo lelijk is dat geen man haar wil. Maar nadat ze onder druk van haar baas een cosmetische operatie heeft ondergaan, belichaamt ze de Ideale Vrouw. Ze is dan zo onnatuurlijk mooi dat ze als travestiet gaat optreden in een nachtclub: 'zij [...] deed [net] alsof ze een man was die net deed alsof hij een vrouw was' (121). Dat gaat goed totdat ze ontmaskerd wordt door haar voormalige werkgever: 'die vrouw was een vrouw!' (123). ${ }^{36}$ De maatschappelijke

\footnotetext{
${ }^{36}$ Deze parodie van een vrouw die een travestiet speelt doet denken aan de parodie van de homoseksueel die een (hetero)man speelt, die in het hoofdstuk over De vierde man centraal stond. Een
} 
verontwaardiging over Godelieves 'bedrog' is groot, en zij wordt aan de schandpaal genageld 'omdat zij een echte vrouw was'(136). Daarop sluit zij zich aan bij een feministisch groepje, de Johanna's.

De gekke Lydia en de lelijke Godelieve kunnen beschouwd worden als twee extreme verbeeldingen van de voor vrouwen beschikbare posities in het perpetuum mobile: de één is een madwoman, de ander een monster. Voor Renate ligt het anders. Zij stelt de absurditeit van die vrouwelijke positie aan de kaak, en weet zichzelf staande te houden - anders dan haar zusje, Lydia en Godelieve -, omdat ze een stem heeft: 'Dat ik nog leef, komt doordat ik iets bezit wat te weinig vrouwen bezitten: ik heb een stem en daar schreeuw ik het mee uit, ik heb een stem van papier [...]'(143). In een haast ademloze slotmonoloog, gericht aan haar tot therapeut gebombardeerde dokter Kaplan zegt ze:

[I]k [bezit] een stem [...] die mij heeft doen ontkomen aan de opdracht alleen maar gezien en nooit gehoord te worden, een stem die het mij mogelijk heeft gemaakt te ontsnappen aan het lot van mijn lichaam, dezelfde stem, om nu ter zake te komen, die mijn zusje op een dag had willen bezitten. (144)

Renate heeft zich ontworsteld aan de opdracht om 'alleen maar gezien en nooit gehoord te worden', de opdracht aan alle vrouwen, dankzij haar feministische opstandigheid. Daardoor is haar leven anders gelopen dan dat van de andere vrouwen in het boek. Van Heijst wijst op het belang van de stem: 'De stem [...] wordt de metafoor om haar eigenstandige positie te beschrijven. [...] "Renate" zet haar schrijf-stem in om haar onvrede te ventileren en de leefwereld van de andere lijdende vrouwen te verbeelden' (Van Heijst 1993, 96-97). ${ }^{37}$ Hiervoor beschreef ik hoe Nancy Armstrong de stem aanwijst als een van de centrale metaforen van de tweede feministische golf. ${ }^{38} \mathrm{Zij}$ ziet een parallel tussen de

vergelijking voert nu te ver, maar het zou interessant zijn om te onderzoeken of het effect van de parodie in Perpetuum Mobile een ontmaskering van 'echte' vrouwelijkheid is, zoals in De vierde man echte mannelijkheid/heteroseksualiteit werd ontmaskerd.

${ }^{37}$ Van Heijst verwijst naar psychologisch onderzoek van Mary Field Belenky en haar collega's 'die [...] concludeerden dat de vrouwen "de metafoor van de stem herhaaldelijk gebruikten om hun intellectuele en morele ontwikkeling te beschrijven en dat de eigen stem, de eigen geest en de eigen persoonlijkheid onlosmakelijk met elkaar verbonden waren."' (Belenky geciteerd in Van Heijst 1993, 196 noot 11).

${ }^{38}$ Er zijn talloze voorbeelden van feministische titels waarin de vrouwelijke stem wordt benadrukt. Een kleine greep: Claire Kahane, Passions of the voice: hysteria, narrative, and the figure of the speaking woman, 1850-1915 (1995); Fokkelien van Dijk-Hemmes, De dubbele stem van haar verlangen (1995); Aurora Wolfgang, Gender and voice in the French novel, 1730-1782 (2004); 
narratieve strategieën van de Victoriaanse roman en die van feministen, in de nadruk die cultural agency krijgt. Renate krijgt dankzij haar stem agency en verwerft daarmee een plaats in de maatschappij.

De vrouwelijke stem, zoals dat toen heette, is direct verbonden met de tweede feministische golf. Renate Dorrestein was in 1986 een van de initiatiefnemers van de Anna Bijnsprijs, de tweejaarlijkse prijs 'voor de vrouwelijke stem in de literatuur'. ${ }^{39}$ Een ander voorbeeld: een belangrijk actierepertoire van de tweede feministische golf waren de praatgroepen (ook wel bewustwordingsgroepen genoemd). ${ }^{40}$ Daar konden vrouwen hun stem laten horen; bewustwording van de vrouwenonderdrukking begon met het vertellen van ervaringsverhalen. Die verhalen vonden een literaire pendant in wat Maaike Meijer de 'fictionele autobiografie' doopte; het bekendste Nederlandse voorbeeld is De schaamte voorbij (1976) van Anja Meulenbelt. Meijer stelt dat in dit nieuwe autobiografisch-feministische genre 'het bewustmakende werk van de praatgroepen op schrift' gezet werd (Meijer 1993, 823). Perpetuum mobile is een voorbeeld van zo'n verhaal volgens Meijer.

Communicatiewetenschapper Irene Costera Meijer beschrijft de verschillende functies die feministische bewustwordingsverhalen vervulden: 'Vrouwen leerden door het lezen ervan zichzelf en elkaar als vrouw, als mens en als uniek

María Teresa Medeiros-Lichem, Reading the feminine voice in Latin American women's fiction (2002); Jerilyn Fisher and Ellen S. Silber [ed.], Analyzing the different voice: feminist psychological theory and literary texts (1998); Janet A. Kourany, ed., Philosophy in a feminist voice: critiques and reconstructions (1998); Janet A. Flammang, Women's political voice: how women are transforming the practice and study of politics (1997). Alida Brill (ed), A rising public voice: women in politics worldwide (1995). Tamar Frankiel, The voice of Sarah: feminine spirituality and traditional Judaism (1990). Susan Canty Quinlan, The female voice in contemporary Brazilian narrative (1991); Martha M. Solomon (ed), A voice of their own: the woman suffrage press, 1840-1910 (1991); Evidence on her own behalf: women's narrative as theological voice (1990); Carter Heyward, Speaking of Christ: a lesbian feminist voice (1989); Marcia Millman and Rosabeth Moss Kanter (eds), Another voice: feminist perspectives on social life and social science (1975).

${ }^{39}$ Vanaf 2001 werd de doelstelling geformuleerd als: 'het bevorderen van de canonisering van het werk van vrouwelijke auteurs'. Zie www.annabijnsprijs.nl/documents/tekst/-renatedorrestein2001.pdf, geraadpleegd 22 november 2009.

${ }^{40}$ Zie Costera Meijer (1996), p. 237-247. Zij schrijft: 'Via het vergelijken van hun ervaringen ontdekken vrouwen wat zij allemaal gemeen hebben met andere vrouwen, dat zij niet de uitzondering, maar de regel vormen. Ervaringsverhalen bewerkstelligen een uitbreiding van het scala van ervaringen dat "gewoon vrouwelijk" zou zijn. De vraag wie gek is en wie normaal gaan vrouwen minder vanzelfsprekend in eigen nadeel beantwoorden' (241-242). Zie ook Van de Loo (2007) p. 108 e.v.; en Van der Klein en Wieringa (red.) (2006) p. 28, waar Anneke van Baalen (van De Bonte Was) wordt aangehaald, die 'deze "metode [sic] om vrijuit te spreken" als het belangrijkste actierepertoire van het radicaal-feminisme beschouwde'. Zie voor een handleiding uit die tijd: Anja Meulenbelt, Vrouwen in praatgroepen: weten hoe het voelt. Sjaloom, 1974. 
zelf te herkennen' (Costera Meijer 1996, 246). Met andere woorden, de verhalen vormden een middel om het collectief van vrouwen uit te breiden, om naar hervorming van de maatschappij (een inclusievere samenleving in de woorden van Armstrong) te streven, en om vrouwen in hun streven naar zelfontplooiing te steunen. Maar hoe verhoudt de individuele expressie van vrouwen zich met een vrouwelijk collectief, oftewel voor welke vrouwen kan een 'vrouwelijke stem' eigenlijk spreken?

De paradox die Armstrong schetste als kenmerkend voor de liberale samenleving - de spanning tussen maximale individuele expressie en het versterken van het collectief - tekent zich ook af binnen de vrouwenbeweging. De 'vrouwelijke stem' bleek niet hetzelfde als de stemmen van vrouwen. Het bleek al snel een heikel punt in het feminisme, met de ontdekking van oneindig veel vrouwelijke identiteiten en het uiteenvallen van de feministische beweging als gevolg. ${ }^{41}$ Volgens Van Heijst gaat Perpetuum mobile over 'het gebrek aan beschikking dat de personages hebben om hun eigen leven te leiden (Van Heijst 1993, 98). Met Armstrong in het achterhoofd zou ik dat formuleren als: het gaat over het conflict tussen 'individualistic energy' en het collectieve belang, of in de woorden van Hella Haasse, de 'worsteling om een zelfstandig individu' te worden: het centrale project van de moderne roman en het moderne subject. Maar zelfstandig ten opzichte van wie?

Dorrestein fulmineert in Perpetuum mobile bij monde van Renate niet alleen tegen de (mannen)maatschappij, die geregeerd wordt door de ideologie van de romantische liefde, maar ook tegen een collectief van vrouwen, aangeduid als de Johanna's: 'een van de obscure sekten waaraan de vrouwenbeweging rijk is. Dit gezelschap, dat leek te bestaan uit vrouwen die altijd allemaal Johanna heetten, hield zich bezig met het opwaarderen van vrouwelijke waarden' (134). Hoewel Renate erkent dat het vrouwelijk aandeel in de cultuur altijd is ondergewaardeerd, ziet ze niets in de strategie van de Johanna's om vrouwelijke eigenschappen op te hemelen: '[z]ij bevestigden [...] de oude leugen die de geslachten altijd in het gareel heeft gehouden: dat mannen en vrouwen verschillend zijn, elkaars complementaire helften, elk met een eigen taak.' (135). Renates samenvatting van de bezigheden van de Johanna's, die vrouwen beschouwen als 'hoedsters en voedsters' (134) is zeer geestig:

Ik bezag ze altijd als een troepje warhoofden, met hun middagjes kraanvogels-vouwen-voor-de-vrede, hun van zeewier gevlochten tampons en hun

\footnotetext{
${ }^{41}$ Zie Costera Meijer (1996) voor een gedetailleerde analyse van de verschillende feministische posities in Nederland.
} 
diepe inzichten in yin, yang en Jung. De menstruatiedans! De zelfgebakken tarwebol! Het communiceren met de baarmoeder! Bracht me dat even schot in de zaak! (135)

Renate ziet tot haar afgrijzen dat Godelieve, die na haar cosmetische operatie de Ideale Vrouw belichaamt, wordt ingelijfd door de Johanna's. Dat gebeurt nadat Renate een vlammend feministisch interview met Godelieve heeft gemaakt over het onrecht dat haar is aangedaan - dat ze wordt aangeklaagd omdat ze een echte vrouw is. De Johanna's beschouwen Godelieve als hun martelares - 'hier hadden zij een tot echt verklaarde vrouw bij de kladden' (136) - en Godelieve laat zich hun verering graag aanleunen. Renate realiseert zich dat ze zo boos is op de Johanna's, omdat die Godelieve als feministisch boegbeeld hebben binnengehaald terwijl ze ook voor Renate een feministische heldin was. $\mathrm{Zij}$ had namelijk, zo zegt ze 'in Godelieves geschiedenis [...] ook mijn eigen speerpunten herkend' (136). Dankzij Renates eigen interview groeit Godelieve uit tot de feministische lieveling van het Nederlandse publiek. Terwijl Renate als feminist de vreselijkste verwensingen naar haar hoofd krijgt, maakt Godelieve het feminisme respectabel - het Johanna-feminisme wel te verstaan.

Daarmee wordt Godelieve een unheimliche dubbelganger van Renate, de monsterlijke uitvoering van haarzelf: 'Godelieve Ochtendster was mijn monster van Frankenstein, en met kracht verdrong ik elke gedachte aan haar' (96). ${ }^{42}$ Renate heeft Godelieve zelf gecreëerd, als Victor Frankenstein zijn monster. Renate was immers zelf verantwoordelijk voor Godelieves geboorte als feminist, zij heeft als interviewer Godelieve een stem gegeven. Zoals het monster van Frankenstein ambieerde bij de mensen te horen, zo wil Godelieve bij de feministen horen. $\mathrm{Zij}$ erkent impliciet haar schepper Renate, als ze zegt 'Jij hebt me de ogen geopend' (152), maar Renate gruwt van haar schepsel. ${ }^{43}$ Afgaande op de

\footnotetext{
${ }^{42}$ Sommige recensenten (Osstyn 1989, Warren 1989) leken Perpetuum mobile voornamelijk realistisch te lezen, maar alleen al deze uitspraak verwijst Godelieve naar het rijk van de fictie. Zie Van Hoof (1997) voor een analyse van de receptie van Dorresteins werk.

${ }^{43}$ Deze verstoting van schepsel door schepper is een herhaling van Godelieves afwijzing door haar moeder. Godelieves ouders houden zich bij voorkeur op in bed om niet met hun dochters lelijkheid geconfronteerd te hoeven worden. Als de driejarige Godelieve op een ochtend haar vrijende ouders aantreft - Freuds primal scène - wordt ze vooral getroffen door de verliefde blik waarmee ze elkaar aankijken. Als ze zichzelf vervolgens in de spiegel van de badkamer met net zo'n blik bekijkt, schenkt haar dat veel plezier: 'Godelieves knieën werden er slap van [...] haar spiegelbeeld [...] werd helemaal roze in het gezicht en de ogen vonkten van plezier' (59). Dan ziet ze via de spiegel haar moeder, die probeert te glimlachen, maar louter ontzetting en afkeer uitstraalt bij de aanblik van haar lelijke dochter. Die kille blik herkent Godelieve als die van haar pop: 'kille blik, ogen dicht. Kille blik, ogen dicht' (59). 'Maar hoe Godelieve ook schudde, elke keer als ze open-
} 
reacties van het publiek lijken de rollen precies andersom: niet Godelieve wordt gezien als monsterachtig, maar Renate: zij krijgt voortdurend 'haar kop eraf!'(100) te horen, net als Alice in Wonderland.

Wanneer een ingezondenbrievenschrijver erop aandringt dat Renate een rustkuur neemt ('als was ik Charlotte Perkins Gilman' 101) (4 $^{44}$ en aanbiedt om wat goede gesprekken met haar te voeren 'bij een goed glas wijn' (101), ontploft Renate over deze 'wijnschenker':

En wij dachten nog wel dat we in de twintigste eeuw leefden, terwijl we in realiteit nauwelijks één stap verwijderd waren van de normen en waarden van de Victoriaanse salon: het onzegbare dient ongezegd te blijven, de oren die niet willen horen moeten niet geaffronteerd worden met een schreeuw, en achter kamerschermen zitten bleke jongedames suf geluld aan een goed glas wijn met een heer die hun vertelt hoe de werkelijkheid in elkaar steekt, namelijk dat vrouwen er zijn om gezien en niet om gehoord te worden, met als beloning daarvoor dat zij als wezenloze prinsessen op de erwt geïdealiseerd zullen worden - een toestand die net zo beknottend is als eenzame opsluiting in een van de kerkers uit de gotische literatuur, een genre dat niet voor niets door vrouwen groot is gemaakt. Hoe graag had ik [...] the mad woman in the attic willen zijn! Dan kon je razen en tieren en iedereen de stuipen op het lijf jagen, en kreeg je toch elke dag een bord warm eten. Net als de gemiddelde man, door de tijden heen! (101-102)

Deze tirade draait helemaal om de stem en gehoord willen worden. Renate voert de gothic novel op om de nog altijd voortdurende beknotting van vrouwen te onderstrepen. Vrouwen mogen nog steeds niet hun stem gebruiken, mogen

\footnotetext{
schoten waren ze nog steeds van glas en staarden ze haar koud aan, om zich dan, als in afschuw, weer snel te sluiten.'(59). Godelieve hoopte dat haar blik beantwoord zou worden, dat de blik naar haar moeder een wederkerige wordt, waarin affect bevestigd wordt en niet ontkend. Dat gebeurt niet: en dus heeft dat - de ideeën van Frank en Tomkins volgend - een unheimlich effect. Godelieve steekt haar pop de ogen uit, eigenlijk zoals ze haar moeder de ogen uit had willen steken. Godelieves verlangen is tegengesteld aan dat van de heilige Lucia die niet begeerd wilde worden en daarom haar eigen ogen uitrukte: Godelieve wil niets liever dan begeerd worden, door haar moeder in dit geval. In plaats daarvan wordt ook zij met een soort overlevingsschuld opgezadeld: de wetenschap dat haar ouders haar liever niet hadden gekregen. Ook in Perpetuum mobile wordt de heilige Lucia een aantal malen aangeroepen. Voor een interpretatie daarvan zie Andeweg (2010).

${ }^{44}$ Perkins Gilman schreef het beroemde verhaal The Yellow Wallpaper (1892), waarin een vrouw tegen haar zin een rustkuur ondergaat en zich steeds meer identificeert met een vrouw die ze achter het patroon van het behang meent te ontwaren.
} 
zich niet laten horen. De gothic novel is in dit citaat net als bij Moers c.s. het genre bij uitstek dat de onderdrukking van vrouwen verbeeldt. Om zich los te maken van die normen zou Renate zich willen identificeren met de madwoman in the attic: dan zou ze immers kunnen razen en tieren. Dat doet ze echter niet. Renate wil zich niet gek laten maken, anders dan Lydia houdt ze haar hoofd erbij.

Renate wil haar stem gebruiken, haar stem als vrouw, om zich te verzetten tegen de heersende normen. Maar uiteindelijk wantrouwt ze de stem van een madwoman, of die van een Johanna: ze is ervan overtuigd dat die 'vrouwelijke stem' uiteindelijk alleen maar een bevestiging vormt van de heersende ideologie. Vrouwen zijn niet veroordeeld tot die 'vrouwelijke stem', aldus Renate: '[D]ie vrouwelijke stem [is] natuurlijk niet een biologisch gegeven, want er zijn genoeg vrouwen die verkiezen zich [...] naar de conventies van de dominante cultuur te schikken. [...] Men is een moffenhoer dan wel een Johanna, of men is zichzelf trouw!' (147). ${ }^{45}$ Renate presenteert drie mogelijke posities voor vrouwen. Allereerst kunnen ze zich voegen naar de sociale orde. Dat is een vorm van collaboreren met het kwaad (als 'moffenhoer'). Ze kunnen ook in opstand komen: ofwel door zich te voegen naar het collectief van vrouwen (als 'Johanna'), of door te kiezen voor het feministische individu ('of men is zichzelf trouw!').

Nancy Armstrong laat zien hoe het genre van de roman bemiddelt in de spanningen tussen het moderne individu en de gemeenschap. Maar Armstrong besteedt geen aandacht aan de mogelijkheid dat het individu zich heeft te verhouden tot verschillende gemeenschappen, met alle paradoxale gevolgen van dien. Waar zij spreekt van de gemeenschap bedoelt ze steeds de maatschappij, de sociale orde waarin het individu via een sociaal contract (Locke) een plaats krijgt. In Perpetuum mobile is sprake van twee verschillende gemeenschappen, ten eerste 'de maatschappij' en ten tweede de Johanna's. ${ }^{46}$ Dorrestein voegt er dus een collectieve laag tussen: een gemeenschap van feministische vrouwen, gebaseerd op 'vrouwelijke' waarden. Op die manier legt ze de diepe ambivalentie bloot die aan de tweede feministische golf ten grondslag ligt: enerzijds is het 'wij-vrouwen' een enorme mobiliserende kracht om hervorming van de maat-

\footnotetext{
${ }^{45}$ Ik herinner nog even aan de mise en abyme in Noorderzon over Anna Henker, de echtgenote van de kampbeul. In strikte zin van het woord is zij geen moffenhoer (met die term doelde men op vrouwen die tijdens WO II een relatie met een Duitse soldaat hadden), maar zij is in die roman wel het voorbeeld bij uitstek van de vrouw die zich schikt in de bestaande orde.

${ }^{46}$ Die naam roept de gewoonte in herinnering in protestbewegingen van de jaren zeventig, waaronder het feminisme, om artikelen alleen met de voornaam te ondertekenen. Zie ook Costera Meijer (1996), 313 noot 36.
} 
schappij te bewerkstelligen. Anderzijds is het een dwingend collectief dat zelf nieuwe conflicten tussen individu en gemeenschap oproept. ${ }^{47}$

Dorrestein kiest hier bij monde van Renate onverkort voor het individu, en datzelfde deed ze in Noorderzon. In Noorderzon komt geen bemiddeling tussen individu en gemeenschap tot stand. Misschien is dat de reden waarom de recensies zo slecht waren: dat maakt het in termen van Armstrong een mislukte roman. ${ }^{48}$ Het interessante van Perpetuum mobile is dat de gotieke elementen die erin te vinden zijn, afgezien van de bovenstaande 'kerkers van de gotische literatuur', eerder aansluiten bij Armstrongs lezing van het gotieke: het gotieke verschijnt daar als manier om alternatieve vormen van verwantschap te verbeelden dan het kerngezin. In de volgende paragraaf bespreek ik of die gotieke elementen als utopisch gelezen kunnen worden.

\section{VAMPIRISTISCH ZUSTERSCHAP}

Zusterschap krijgt in Perpetuum mobile gestalte als een vampiristische relatie. Hoe ziet dat er precies uit? Renate en haar zusje, die niet bij name genoemd wordt, hadden een identiek verlangen: ze wilden allebei schrijfster worden. In de roman is er dan ook sprake van een collectief 'wij' als de zussen elkaar verhalen vertellen: 'wij hadden de niet zo heel gangbare opvatting dat schrijverschap veel te maken heeft met het vermogen een goed verhaal te vertellen' (70). Ook als ze samen naar de psychiatrische inrichting rijden waar het zusje zal worden opgenomen is dat collectief er: 'Wij stappen uit. Wij verzamelen moed. Wij beginnen het ene been voor het andere te zetten' (72-73). Het 'wij' doet hier absurd aan, maar Renate kan zich niet voorstellen 'hoe een psychiater het verschil had kunnen zien' (73) tussen hen tweeën.

Toch valt dat verschil op gegeven moment niet meer te ontkennen: Renate slaagt erin het verlangen om schrijfster te worden te verwezenlijken, maar haar zusje niet. Ook als het zusje dood is, blijft Renate gesprekken met haar voeren.

\footnotetext{
${ }^{47}$ Zie bijvoorbeeld Costera Meijer (1996) 277-286, die feministische discussies beschrijft over autonomie versus collectiviteit en vrouwelijke waarden versus zelfontplooiing.

${ }^{48}$ Noorderzon kreeg negatieve recensies in Vrij Nederland (Breedt Bruyn 1986), NRC Handelsblad ('t Hart 1986), Amersfoortse Courant ([Anon] 1986), gemengd was De Standaard (De Bouw, 1987). Ik heb geen recensies kunnen vinden in Trouw en de Volkskrant. Positief waren regionale kranten als Brabants Nieuwsblad (Van Eck 1986), Nieuwsblad van het Noorden (Van den Blink 1986) en het Leids Dagblad (Linders-Nouwens 1986. Jaren later, in 1992, stak Antoine Verbij de loftrompet over Noorderzon: '[a]llemachtig, wat zaten die recensenten ernaast! Want Noorderzon $[\ldots]$ is van al haar boeken nog immer het beste, want het rijkste, het onvoorspelbaarste, het mystiekste, het katholiekste, het middeleeuwste [...]' (Verbij 1992, 29). Het gotiekste, zou ik zeggen.
} 
's Nachts neemt een 'diabolische agitatie' (85) bezit van haar waardoor ze koortsachtig schrijft; een foto van haar zusje op haar bureau 'om naar te kijken als ik even vastraakte' (86). Ze werkt aan een nieuw boek, haar derde, waarin Noorderzon te herkennen valt: 'Dit boek [...] zou gaan over iemand die betrokken was geraakt bij een dodelijk verkeersongeval, en daarna louter door schuldgevoel door het leven werd voortgedreven.' (85). De diabolische agitatie openbaart zich ook fysiek: Renate krijgt last van een verscheurende kiespijn. Ze neemt langzamerhand de trekken aan van een vampier. Haar vingers zijn 'om de pen gekromd, geklauwd' (87), haar kaken kraken, en ze voelt de hoektanden haast letterlijk doorbreken: 'het donderde en bliksemde in mijn gebit als in een griezelfilm' (88). Als ze na een nacht van helse tandpijnen op haar lip heeft gebeten sijpelt er zelfs wat bloed langs haar hals. Ze kijkt naar de foto van haar zusje 'alsof ik de inspiratie uit haar kon zuigen' (103).

Wie precies de vampier is - het zusje of zij - valt niet vast te stellen. Renate voelt zich tegelijkertijd bezeten, en op het punt staand bezit te nemen van haar zusje. Zo gaat dat nu eenmaal bij vampiers, zoals Armstrong duidelijk maakte. Vampiers hebben een collectief bewustzijn, de beet van de vampier betekent het einde van het individu: ben je er één, dan ben je ze allemaal. Renates transformatie tot vampier creëert een nieuw perpetuum mobile:

De vloek van deze boze daad is dat die verder kwaad zal baren: evenals de vampier zelf wordt haar slachtoffer namelijk een zogenoemde ondode, en zo perpetuum mobile [...]. De vampier beneemt haar prooi dus niet alleen het leven, zij ontneemt het slachtoffer ook diens dood; zij maakt het onmogelijk dat men tot in alle eeuwigheid ongestoord rust. (104)

Het in deze roman zo centrale begrip perpetuum mobile wordt in dit citaat in een nieuwe context gebruikt. Het vampiristische collectief verschijnt als een alternatief voor het perpetuum mobile 'van de liehiefde'. Het slachtoffer van de vampier wordt deel van een collectief, net zoals Armstrong las in Dracula, 'en zo perpetuum mobile'. Het perpetuum van de liefde is erop gericht de sociale orde te reproduceren door de vorming van een gezin, oftewel zoals Renate het sarcastisch verwoordt, met een 'kroon op uw liehiefde'. Renate verzet zich zoals te verwachten valt tegen die 'kroon': haar minnaar wordt aan de kant gezet zodra hij een kind wil. Het alternatieve, vampiristische perpetuum mobile is ook een manier om een gemeenschap te vormen. Maar hoe groot Renates afkeer van het kerngezin ook is, het collectief van zusters wekt evenzeer haar afschuw. De vampiristische gemeenschap wordt door het kwaad gebaard en zal 'verder kwaad baren', en verhindert dat de doden kunnen rusten in hun graf. En daardoor 
blijft Renate zich bezeten voelen. Terwijl Armstrong utopisch potentieel ziet in de gemeenschap van vampiers, slaat in Perpetuum mobile de balans de andere kant uit.

De nacht dat Renate denkt dat ze een vampier is, markeert het moment dat ze erkent dat ze zich schuldig voelt over haar zusjes dood. Tot die tijd had ze elk schuldgevoel ontkend, 'want als $\mathrm{ik}, \mathrm{ik}^{\mathrm{ik}} \mathrm{ik}^{49}$ dat niet had gekund [haar zusje redden, AA], was dat dus een aperte onmogelijkheid.' (106). En daarmee was haar zusjes dood onvermijdelijk en schuldgevoel dus niet ter zake doende. Renates schuldgevoel bestaat niet alleen uit het 'standaardschuldgevoel van overlevende' (107), of over het feit dat zij haar zusje indertijd zelf naar een psychiatrische inrichting heeft gebracht. Nu zij succes heeft als schrijfster en haar zusje dood is, is Renate bezeten door de gedachte dat zij voordeel heeft gehad bij haar zusjes dood, dat zij teert op haar talent:

O, een deel van mijn door wijnschenkers belaagde hoofd weet wel dat die gedachte irrationeel is, maar het andere deel drukt zich tegen het dode hoofd van mijn zusje, zoals de tanden van een vampier in een blanke hals glijden, onweerstaanbaar word ik aangetrokken door de inhoud: de ontbrekende helft van mijn talent. Hoe ik zuig! En dat zet de kroon op mijn schuldgevoel: niet zomaar lig ik nachtenlang te fluisteren tegen mijn zusje [...]. Wat ik werkelijk doe is haar wakker houden, [...] Zolang mijn bloeddorst naar erkenning niet is gestild, mag zij niet rusten. Ik houd haar ondood. (109)

Renates vampiersgedrag vormt de 'kroon' op haar schuldgevoel, zij zuigt het talent op van haar zusje, die ook schrijfster had willen worden. Door zich te voeden met haar zusje krijgt ze zelf ook geen rust, zoals blijkt uit de 'krankzinnige razernij' (106) die haar kwelt.

Pas door de slechte ontvangst van haar derde roman - dat is Noorderzon begrijpt Renate dat dat boek echt haar eigen werk is: 'mijn zusje had zeker geen boek willen schrijven dat werd neergesabeld op een wijze die van links naar rechts dwars door de ziel sneed' (144). Als het zo slecht is, moet het wel van haarzelf zijn. Dit besef geeft haar het gevoel (terug) dat ze niet alleen de auteur van haar eigen werk is, maar ook van haar eigen leven. De slechte ontvangst van Noorderzon is dus cruciaal voor Renates gevoel van individualiteit. Terwijl ze aan het begin van Perpetuum mobile nog schrijft: 'ik ben schrijfster, ik heb de

\footnotetext{
${ }^{49}$ Dit 'ik, ik, ik' is een echo van het gansje Ich-ich-ich in Noorderzon, dat wordt overreden als hoofdpersoon Topaas haar laat schrikken, wat opnieuw appelleert aan Topaas' overlevingsschuld.
} 
macht het bekende scenario te herschrijven' (37), is het bevrijdend als blijkt dat haar macht als schrijfster beperkt is. De paradox is dat ze bevestigd wordt in haar individuele schrijverschap op het moment dat ze faalt als schrijfster. Pas dan kan ze zich losmaken uit het collectieve schrijverschap met haar zus.

Zusterschap is een bekende metafoor in de vrouwenbeweging van de jaren zeventig om de solidariteit tussen vrouwen aan te duiden. ${ }^{50} \mathrm{Ik}$ denk dat de vampiristische verhouding tussen de zussen, waarbij het Renate veel moeite en pijn kost om haar eigen drijfveren te onderscheiden, gelezen kan worden als een allegorie over feministische solidariteit. De Johanna's vormen een collectief dat geen individuele verschillen meer kent. Ze worden met een meervoud aangeduid en zien er allemaal hetzelfde uit: dat wijst erop dat ze allemaal identiek zijn aan elkaar. Dit collectief van zusters heeft ook maar één verlangen: 'dat de zachte krachten zullen overwinnen' (137). ${ }^{51}$ De Johanna's kunnen ook in termen van vampirisme worden beschreven. Zo wordt Godelieve, die de Ideale Vrouw belichaamt, letterlijk 'geannexeerd' (134): 'Zij droeg haar haren nu in gordijntjes, in Johanna-trant, en ging gekleed in de uitrusting waarin de sekte zich uitdoste' (137).

Renate zegt met zoveel woorden dat het vrouwencollectief niet verschilt van het vampierscollectief: 'wat is in de grond het verschil tussen de Ideale Vrouw en graaf Vlad en de zijnen? Beiden zijn even fictief en bestaan slechts in broeierige breinen' (105). Dit vampiristische collectief heeft voor Renate - anders dan voor Nancy Armstrong - geen utopische kanten. Renate is blij dat ze weet te ontsnappen aan haar tijdelijke overtuiging dat ze een vampier was. Het is haar redding dat haar gekte een particuliere gekte is, en geen collectieve: 'daarom had niemand de moeite genomen mij in mijn waanzin te bevestigen, of te bevorderen dat ik een beetje harder mijn best deed een vampier te zijn.' (105). Met andere woorden: er werd gelukkig geen collectieve druk op haar uitgeoefend om zich aan te sluiten, zoals bij de Johanna's.

Het kost Renate echter veel moeite om haar zelfstandige positie ten opzichte van de Johanna's af te palen, net zoals ze haar individualiteit ten opzichte van haar zusje moet bevechten door haar demonische anwezigheid uit te drijven. De Johanna's hebben toch bezit van haar genomen, want Renate moet erken-

\footnotetext{
${ }^{50}$ Denk aan de feministische leus 'Sisterhood is powerful'; zie bijvoorbeeld ook Marijke Ekelschot \& Anneke van Baalen, Zusterschap en daarna (1982). Nederland kende in de jaren tachtig Sister Outsider, een groep zwarte feministische vrouwen. Een bloemlezing uit die tijd: Robin Morgan, Sisterhood is global: the international women's movement anthology (1985).

${ }^{51}$ Een verwijzing naar een gedicht van Henriëtte Roland Holst: 'De zachte krachten zullen zeker winnen / in 't eind - dit hoor ik als een innig fluistren / in mij: zoo 't zweeg zou alle licht verduistren / alle warmte zou verstarren van binnen.' (met dank aan Janny Andeweg).
} 
nen dat haar pogingen om haar zusje (en buurvrouw Lydia) te redden voortkomen uit eenzelfde gevoel van superioriteit als de Johanna's. Ze heeft zich als 'hoedster' gedragen, als redder van de wereld: '[I]n alle ernst achtte ik mezelf in staat dood en gekte te voorkomen en, megalomaan, hield ik mezelf verantwoordelijk wanneer het leven anders besliste' (153). Ze heeft zich dus net als een Johanna gedragen:

Wat was ik anders dan een huisvrouw die graag wil geloven dat zonder haar eeuwige gedweil en geredder alles in het ongerede zal raken? [...] In welk opzicht verschilde ik nou helemaal van de Johanna's, ik die mijn eigen gefrustreerde machteloosheid, mijn onvermogen, mijn wens te beïnvloeden en te bewerkstelligen, had verheven tot een onmisbaar instrument voor andermans heil of onheil?

Punt voor de Johanna's! (154)

Renate kan haar eigen inzet niet meer onderscheiden van die van de Johanna's, hoezeer ze hen ook verafschuwt. Tegen wil en dank heeft ze de opvattingen van dat feministische collectief overgenomen - alsof ze zonder het te weten is gebeten door de vampier. Net als in Noorderzon ontstaat hier een paradox: erkenning van het gebrek aan macht over de gebeurtenissen leidt tot besef van individualiteit. Er zijn grenzen aan wat maakbaar is, maar juist daardoor ervaart Renate de begrenzing van zichzelf. Op het moment dat Renate beseft dat zij zich in feite identiek gedroeg als de Johanna's, wordt de weg vrijgemaakt naar het loslaten van haar zusje:

Maar misschien [...] als ik ons beiden kan zien als separate individuen zonder macht over elkaars lot, als ik het aandurf van haar gescheiden te raken, misschien dat ik haar dan niet langer als een demon van me af hoef te stoten, of als een prooi naar me toe hoef te halen [...] (155-156)

In een gemeenschap van zusters kost het vinden van een eigen stem, het losmaken van die gemeenschap moeite. Dat geldt zowel voor zusterschap binnen een gezin als voor feministisch zusterschap. Het proces om van 'wij' weer 'ik' te worden is pijnlijk. In beide gevallen kost het Renate moeite zich los te maken, het is een strijd contre coeur. Het persoonlijke zusterschap wordt uiteindelijk opnieuw gedefinieerd als een relatie tussen twee verschillende individuen. De liefde tussen de zussen wordt niet expliciet benoemd, maar er kan wel voorzichtig naar gewezen worden: Renate hoopt dat ze de herinnering aan haar zusje 
'gewoon in vriendschap' (156) bij zich kan houden. ${ }^{52}$ Verwantschap krijgt gestalte als vriendschap en niet in de eerste plaats als bloedband. Ook het collectieve, politieke zusterschap zou anders vorm moeten krijgen, maar voor die band tussen vrouwen is (nog) geen nieuwe formulering voorhanden. Perpetuum mobile eindigt ambivalent:

Ik zou graag willen leven in een wereld waarin persoonlijke drijfveren en verlangens voorrang hadden op massale waandenkbeelden die dwingen tot capitulatie voor de norm. Maar kom, ik kan beter thee gaan zetten voor Lydia. (150)

De utopische wens die hier wordt verwoord is - voor Dorrestein en voor Perpetuum mobile - in opvallend sekseneutrale bewoordingen gesteld. Volgens Armstrong zouden we een wereld waarin het individu zich niet hoeft te onderwerpen aan de gemeenschap verbeeld kunnen zien in romans vóór of voorbij de Victoriaanse roman. Renates berustende eindzin ('Maar kom, ik kan beter thee gaan zetten') verraadt dat het volgens haar nog niet zover is. Hoewel zij haar individualiteit heeft teruggevonden, neemt ze alsnog de zorgzame (vrouwen)rol ten opzichte van Lydia. ${ }^{53}$ We zouden dit citaat ook positiever kunnen interpreteren: hoewel het in eerste instantie een pleidooi lijkt voor het liberale, individuele ideaal ('persoonlijke drijfveren'), eindigt Dorrestein met de noodzaak tot onderlinge zorg. Als die zorgzaamheid nu sekseneutraal wordt opgevat, en niet als typisch vrouwelijk, is er heel wat bereikt.

Het gotieke is bij Dorrestein niet uitsluitend een manier om de feministische strijd van vrouwen voor zelfstandigheid ten opzichte van mannen vorm te geven, zoals in de eerste interpretaties van female gothic. Het gotieke biedt echter ook geen utopisch vergezicht op een nieuw soort collectief, zoals Armstrong betoogt. In Perpetuum mobile keert het gotieke zich naar binnen, naar de vrouwengemeenschap zelf. De vampiristische gemeenschap van zusters is de bedreiging voor het vrouwelijke individu. Dorrestein geeft de verhouding tussen feminisme en het gotieke een nieuwe draai in Perpetuum mobile.

\footnotetext{
52 Van Heijst noemt 'liefde' een lege plek in de tekst (vergelijk Letter en Geest waar het woord ook niet uitgesproken kan worden). Pas als met het romantische liefdesideaal is afgerekend, 'is het mogelijk om - zij het in bedekte termen - op liefde te zinspelen.' (Van Heijst 1993, 134).

${ }^{53}$ In het Nieuwe Testament is Lydia een symbool van gastvrijheid: zij is een welgestelde zakenvrouw die de apostel Paulus in Filippi gastvrij ontvangt, zie Handelingen der Apostelen 16:14. Met dank aan Marijke Huisman.
} 



\section{6}

\section{HET VERLANGEN NAAR VERLANGEN Spookliefde van Vonne van der Meer ${ }^{1}$}

Wie Vonne van der Meers zesde roman Spookliefde. Een Iers verhaal (1995) leest na Renate Dorresteins Noorderzon, waarover ik in het vorige hoofdstuk schreef, ziet ongetwijfeld een aantal overeenkomsten. In beide romans vertrekt een vrouw naar een afgelegen eiland, alwaar ze een band met een zwakbegaafde jongen krijgt. De omgeving van beide vrouwen plaatst vraagtekens bij de toewijding waarmee ze de jongen dingen probeert te leren. De jongen sterft in beide gevallen. Zowel Spookliefde als Noorderzon laat een preoccupatie zien met dubbelgangers en plaatsvervangers, en in beide romans wordt de vrouw vergeleken met een vogel - in Noorderzon lijkt daadwerkelijk een transformatie van vrouw tot vogel plaats te vinden; in Spookliefde blijft het bij de metafoor. Ook de vertelsituatie is vergelijkbaar: de hoofdpersoon vertelt haar verhaal aan een jonger meisje, dat op het punt staat haar plaats in te nemen. Hier wordt met andere woorden iets overgeleverd van vrouw op (jongere) vrouw.

Verschillen zijn er natuurlijk ook. Het eiland in Spookliefde is vrij precies gelokaliseerd: de ondertitel van Spookliefde is 'Een Iers verhaal'. Het eiland in Noorderzon ligt 'in het noorden'.2 Terwijl Topaas in Noorderzon de dertig is gepasseerd, is Phil, de hoofdpersoon van Spookliefde, pas zeventien. Topaas komt uit vrije wil naar het eiland om met zichzelf in het reine te komen, Phil komt min of meer gedwongen bij haar ouders wonen. $\mathrm{Z}_{\mathrm{ij}}$ is niet op zoek naar vergeving van haar schuld zoals Topaas, maar naar verlies van haar onschuld: een seksuele ervaring. In Noorderzon spreekt Topaas haar avonturen vrijwel direct in op cassettebandjes; in Spookliefde vertelt Phil haar belevenissen pas 25 jaar na dato. Tegenover de gejaagde stijl van Noorderzon staat de kalme verteltrant van Spookliefde, tegenover de woekerende verhalen en de extremiteiten bij

\footnotetext{
${ }^{1}$ Dit hoofdstuk is een bewerkte versie van Andeweg (te verschijnen).

${ }^{2}$ Op grond van een naam die Topaas een van de plaatselijke bewoners toedicht valt het eiland eventueel in de buurt van Schotland te plaatsen. Een van de mannen in het café heet volgens Topaas 'vermoedelijk' Eoghann a'Chin Bhig. Die naam is verbonden aan een legende over het eiland Mull (bron: Swire 1964).
} 
Dorrestein, de eenvoudige verhaallijn en het relatief spaarzame gebruik van gotieke elementen bij Van der Meer.

Ondanks die relatieve spaarzaamheid plaats ik Spookliefde in dit hoofdstuk in een gotiek interpretatiekader. Wat Catherine Spooner (2007) schrijft over het werk van een aantal Engelstalige twintigste-eeuwse auteurs geldt wat mij betreft ook voor Van der Meer: 'It is sometimes only by reading them in the light of [...] previous generations [of Gothic writers] that their Gothic aspect emerges' (46). Uit dit citaat blijkt eens te meer de opvatting dat het gotieke geen essentie is, geen verzameling op zichzelf staande teksteigenschappen, maar een potentieel in de tekst dat door de lezer gerealiseerd kan worden. Hoewel ik Spooners uitspraak van harte onderschrijf, ben ik me bewust van het mogelijke risico dat het gotieke lezen met zich meebrengt. Het risico is dat alles gotiek wordt voor wie gotiek verwacht, of zoals Scott Brewster het verwoordde: 'Reading Gothic makes us see things' (Brewster 2000, 281). ${ }^{3}$ Als het gotieke zich alleen zou bevinden 'in the eye of the beholder', met andere woorden een lezerskenmerk zou zijn, is er dan nog een objectief criterium voor wat wel en wat niet gotiek is? Mijn - enigszins pragmatische - antwoord daarop is dat het identificeren van het gotieke altijd neerkomt op een wisselwerking tussen tekst en lezer/es. Mijn voornaamste doel is bovendien niet het identificeren van het gotieke, maar het analyseren van gotieke effecten, niet wat het gotieke is maar wat het doet. Een gotiek interpretatiekader kan betekenissen genereren die met een andere manier van lezen minder snel op de voorgrond zouden treden. Ook in dit hoofdstuk ga ik op zoek naar antwoorden op de vraag wat het gotieke doet in Spookliefde.

Spookliefde zou ik willen omschrijven als een 'griezelig gewone' roman. Het is in strikte zin geen spookverhaal, geen griezelroman, geen horrorscenario. Tegelijkertijd stelt de roman wel met gotieke middelen een wezenlijke kwestie seksueel verlangen - aan de orde, als een spanning tussen traditie en modernisering. Ik heb het gotieke in dit boek steeds opgevat als een culturele strategie waarmee dat soort spanningen verbeeld worden. Mijn vermoeden dat het productief is om Spookliefde te lezen met een gotiek interpretatiekader, wordt versterkt door de genoemde correspondenties met Dorresteins gotieke roman. Ook in de drie boeken die volgden op Spookliefde is Van der Meers affiniteit met het gotieke zichtbaar: Eilandgasten (1999), De avondboot (2000) en Laatste seizoen (2002). Hoewel de setting van die romans alledaags is - geen gotiek landhuis maar een vakantiehuisje op Vlieland - wordt de trilogie mede gestructureerd door het gotieke motief van het afgesloten kamertje dat een geheim herbergt -

\footnotetext{
${ }^{3}$ Zie ook Warwick (2007).
} 
een variatie op het Blauwbaardverhaal. Als het kamertje in het laatste verhaal ten slotte opengaat, blijkt het leeg. ${ }^{4}$

Bij mijn interpretatie van Spookliefde zal ik opnieuw gebruik maken van de inzichten van Robert Mighall (1999). Mighall stelt me in staat om betekenis te geven aan de anachronismen in Spookliefde en om de geografische locaties in de roman als historisch specifiek te interpreteren. Ik vraag me af door welke spanning tussen verleden en heden Spookliefde wordt gestructureerd, wat er als gotiek verleden wordt gerepresenteerd en wat als modern heden. Tegelijkertijd, zo zal blijken, laat Spookliefde de beperkingen zien die Mighalls perspectief op het gotieke heeft. Doordat Mighall gender als categorie expliciet buiten beschouwing laat, is hij niet in staat om historisch veranderlijke aspecten van gender te analyseren.

Spookliefde opent met een naamloos, zeventienjarig meisje, dat als toerist een eiland voor de westkust van Ierland bezoekt. $Z \mathrm{ij}$ heeft net afscheid genomen van haar vriendje Ian en steekt een kaarsje op in de kapel, om haar wens dat hij snel terugkeert kracht bij te zetten. Daar ontmoet ze Phil, een vrouw van begin veertig, die elke dag twee kaarsen opsteekt. Phil waarschuwt het meisje dat ze beter niet kan bidden dat haar wens verhoord wordt - want dat is wat zij zelf als zeventienjarige deed, met dramatische gevolgen. Vervolgens vertelt Phil haar wat zij meemaakte toen ze zelf vijfentwintig jaar eerder, zeventien jaar oud, arriveerde op het eiland. Dat ingebedde verhaal vormt het leeuwendeel van Spookliefde.

De jonge Phil werd al snel verliefd op een man van wie ze later ontdekte dat het er niet een maar twee waren: tweelingbroers. De ene broer, Seamus, was de bard-boekhandelaar-schoolmeester van het eiland; de ander, Michael, was zwakbegaafd en sprak nauwelijks. Phil werd verliefd op Seamus maar kreeg geen respons. In de kerk stak ze kaarsjes op om te bidden dat hij van haar zou gaan houden, maar zonder resultaat. Ze richtte zich vervolgens op Michael om Seamus' jaloezie te wekken, terwijl ze zich voorstelde dat hij Seamus was. Gaandeweg begon ze steeds meer van Michael en zijn zwijgzaamheid te houden en wees Seamus af toen die alsnog verliefd op haar werd. Dat leidde tot een drama. Toen Phil Michael na een dorpsfeest meenam naar huis om eindelijk met hem naar bed te gaan, werden ze gevolgd door Seamus, die Michael met een geweer doodschoot, hoewel hij mogelijk op Phil richtte. Na het dramatische incident vertrekt Phil van het eiland en sticht een gezin, maar ze keert terug om les te

\footnotetext{
${ }^{4}$ In die zin vergelijkbaar met Haasses Sleuteloog (2002), waarin een afgesloten kist als motor voor de herinneringen van de hoofdpersoon werkt; die kist blijkt aan het eind van de roman ook leeg te zijn; zie ook Buikema (2003a).
} 
geven en in de boekwinkel te werken. Ook Seamus keert terug naar het eiland, nadat hij zijn straf heeft uitgezeten. Hij spreekt nooit meer, en zo treft het naamloze meisje hem vele jaren later aan in het café: een vreemde, stille man, die op dezelfde barkruk zit als haar vriendje Ian een dag daarvoor.

Het eiland waar Spookliefde zich afspeelt is, net als het eiland in Noorderzon, een gotieke locatie. Het is haast even geïsoleerd en technologisch achtergebleven: de jonge Phil hoort van haar moeder dat alleen de pastoor telefoon heeft. Het ligt in de periferie van het Europese continent, op een eiland ten westen van Ierland; het is desolaat en het vertoont allerlei tekenen van verval. De boot zit 'vol roestpuisten' en er lopen 'bruine tranen over de witte verf (219); de bootsman heeft 'bruine tanden' (220). Als Phil arriveert ziet ze 'uitsluitend wrakken, rijp voor de sloop' (220). Haar vader komt haar halen in 'een bruine bestelbus' (221) die 'rafelige gaten' (221) in de vloer heeft. Alles roest, zo valt Phil op: auto's, golfplaten daken, zelfs het zeewier op de rotsen en het mos op de muren hebben een roestige kleur. Ook het eiland zelf is aan het afbrokkelen: 'de zee kalft het eiland steeds verder af (223). Het eiland zelf is een gotieke ruïne, een locatie in verval die de nodige geheimen herbergt. Ook vijfentwintig jaar later is het eiland nog een gotieke plek: het naamloze meisje zit graag met Ian bij een 'ruïne op het kerkhof. $Z \mathrm{ij}$ hoort het rondspokende verhaal over een moord die op het eiland heeft plaatsgevonden.

Ook de desoriëntatie van tijd en ruimte die het eiland veroorzaakt is een gotiek effect, om te beginnen met de reis erheen: zodra Phil op de boot stapt begint het te misten, ze kan de horizon niet meer zien en ze kan zich dus niet oriënteren. Alles is vreemd, zelfs haar eigen vader: als hij haar van de boot haalt ziet hij er anders uit, hij ruikt anders en praat anders, over vreemde plekken met sinistere namen als Vissersverdriet en Dodemansgrot. Als hij met haar over het eiland rijdt, heeft ze het gevoel alsof ze een tunnel inrijdt, een paranoïde en claustrofobische ervaring: 'Een tunnel in een droom waarin je achtervolgd wordt maar geen kant op kunt omdat je spieren niet doen wat je wilt' (222).

Andere gotieke elementen in Spookliefde zijn de unheimliche verdubbelingen van personages: Seamus en Michael, Phil en het meisje, Ian en Seamus. Het onschuldige meisje dat op een onheilspellende plek belandt, de dreigende kracht van seksualiteit en de ontdekking van onverwachte familiebanden zijn andere voorbeelden van de gotieke dynamiek. Ook de titel Spookliefde kan als een verwijzing naar het gotieke worden gelezen. Een spookliefde zou een spookachtige liefde kunnen zijn, die nooit werkelijkheid wordt, of een liefde voor het boven- 
natuurlijke. ${ }^{5}$ Beide betekenissen spelen een rol, zoals ik zal betogen. Voor het zover is ga ik in op de geografische setting van Spookliefde.

\section{IERLAND ALS GOTIEKE SETTING}

De stelling die Robert Mighall (1999) met verve verdedigt is dat het gotieke in psychologische interpretaties ten onrechte als per definitie revolutionair of subversief wordt voorgesteld. De gotieke roman wordt dan beschouwd als de plek waar alles uitdrukking vindt wat door normatieve vertogen als burgerlijkheid, rationaliteit, moderniteit of Verlichting wordt uitgesloten en onderdrukt: het irrationele, emotionaliteit, vrouwelijkheid en seksualiteit. Mighall licht zijn standpunten nog eens toe in een polemisch artikel dat hij samen met Chris Baldick schreef (2000):

Misconceiving Gothic fictions as examples of anti-realist 'fantasy' or dreamwriting, [gothic criticism] has repeatedly overlooked their manifest temporal, geographical and ideological referents while constructing increasingly implausible models of their supposed latent fears, desires and 'revolutionary' impulses. (Baldick \& Mighall 2000, 210)

Meer aandacht voor de historische en geografische verwijzingen in gotieke romans zou duidelijk maken dat contemporaine waarden en normen juist vaak bevestigd worden, in plaats van ondermijnd. Baldick en Mighall stellen dat de exotische settings van vroege gothic novels geen tekenen van fantasie, tijdloosheid of escapisme zijn - zoals ze vaak gelezen zijn -, maar juist van waarschijnlijkheid. Vroege gothic novels zoals Ann Radcliffes The Italian (1794) of Matthew Lewis' The Monk (1796) zijn gesitueerd in het Middeleeuwse (katholieke) zuiden van Europa - Italië of Spanje - en niet in 'werkelijk' exotische oorden, zo betogen Baldick en Mighall, omdat deze landen vanuit een Brits perspectief nog stevig vervlochten waren met 'the twin yoke of feudal politics and popish deception' (219), waar zij zich nog van moesten emanciperen. Die gotieke locaties - inclusief de martelkamers en corrupte clerus - zijn dus realistische locaties: aangezien de Inquisitie nog actief was in Zuid-Europa (in Spanje tot 1808), was deze regio de meest voor de handliggende voor de gotieke griezelverhalen en de bevestiging van een moderne, in dit geval Britse, protestantse identiteit.

\footnotetext{
${ }^{5}$ In een interview vertelde Van der Meer dat de titel Spookliefde ontstond door de associatie met 'spookrijder', met iemand die onverwacht opdoemt uit het niets (zie Lodewijks 1995).
} 
Dat is volgens hen de verklaring voor de sterke antikatholieke sentimenten in gotieke romans als The Monk en Melmoth the Wanderer. ${ }^{6}$

De geografische afstand dient om een afstand in tijd vorm te geven, een heel specifieke afstand: die tussen moderniteit en traditie: 'situated between the modern and the medieval worlds, the narrative witnesses the birth of modernity, which is achieved in one generation' (Baldick \& Mighall 220). Die afstand wordt voelbaar gemaakt door anachronismen, die de motor van het gotieke verhaal vormen volgens Baldick en Mighall. Zo'n anachronisme kan de vorm aannemen van een moderne held(in) in een archaïsche context, of andersom, een personage uit het verleden dat weer opduikt in het moderne heden. Een voorbeeld van zo'n laatste anachronisme is de Transsylvaanse Graaf Dracula, die 400 jaar oud is als hij in Victoriaans Londen opduikt.

Baldick en Mighall winden zich op over 'tijdloze' interpretaties van het gotieke. Door hun focus op anachronismen weten ze de anwezigheid van Zuid-Europese, perifere settings in de Britse gothic novel als betekenisvol te duiden voor het bevestigen van een Britse moderne protestantse identiteit. Niet alleen de 'structuur' (noord-zuid, centrum-periferie) maar ook het 'inhoudelijke attribuut' van het katholicisme is betekenisvol voor de setting van de gotieke romans die zij bespreken.?

Spookliefde is zoals gezegd gesitueerd in de periferie, op een eiland ten westen van Ierland en heeft als ondertitel 'Een Iers verhaal'. Ik wil me afvragen hoe Ierland fungeert als gotieke locatie in een twintigste-eeuwse Nederlandse context. Waarom Ierland, waar staat dat voor, in de roman van Van der Meer? En in hoeverre valt het gotieke als een subversieve factor te interpreteren? Of is het

\footnotetext{
${ }^{6}$ Sage (1988) wees al eerder op de antikatholieke sentimenten in de gothic novel. Miles (2007) nuanceert de nadruk op de protestantse identiteit die door gotieke romans gepropageerd zou worden. Hij legt het accent op Brits nationalisme, waar protestantisme wel een belangrijk onderdeel van vormt. Zie ook Wright (2007), 74-96. Charles Taylor (1989) wijst in navolging van Weber op het belang van het protestantisme voor het ontstaan van een moderne notie van identiteit.

${ }^{7}$ De termen zijn afkomstig van Leerssen (2000), die overigens veel onderzoek naar Ierland heeft gedaan (zie bijvoorbeeld Leerssen 1996, 2002). Uit zijn onderzoek naar nationale karakteriseringen komt ook naar voren dat de dynamiek tussen modern en traditioneel via ruimtelijke tegenstellingen wordt verbeeld. Leerssen stelt dat het karakteriseren van nationale en etnische groepen niet zozeer verloopt via inhoudelijke attributen (wat er over wie gezegd wordt, oftewel het 'vocabulaire'), maar via structurele patronen van zelf versus ander (oftewel de 'grammatica'). Voorbeelden van die structurele patronen die werkzaam zijn bij nationale stereotypen, zijn de tegenstelling noord-zuid en centrum-periferie: 'Centrality carries with it the connotation of historical dynamism and development, whereas peripheries are stereotypically "timeless," "backward," or "traditional." [...] In our chronotopical view of the world, journeying away from the centers of societal activity means metaphorically journeying backward in time (Leerssen 2000, 277).
} 
- in de lijn van Baldick en Mighalls analyse - een bevestiging van moderne waarden, en welke dan?

Ierland als gotieke setting is geen onbekend fenomeen. Irish gothic is inmiddels een geaccepteerde, hoewel niet onproblematische categorie in gothic studies, aldus Richard Haslam (2007), die echter wordt gereserveerd voor auteurs van Ierse afkomst en op Van der Meer dus niet van toepassing zou zijn. ${ }^{8}$ Haslam is huiverig voor het allegorisch lezen van het Ierse landschap als uitdrukking van politieke onrust of theologische twisten. Hij benadrukt liever de verschillen tussen gotieke romans van diverse Ierse auteurs, oudere en hedendaagse als John Banville. Hoewel ik Haslams aarzeling bij allegorisch lezen begrijp, lijkt me in het geval van Nederlandse auteurs die Ierland als gotieke locatie kiezen, de vraag naar de betekenis van Ierland als setting wel relevant.'

Diverse recensenten buigen zich bij de verschijning van Spookliefde over de vraag wat de ondertitel 'Iers verhaal' te betekenen kan hebben. Robert Anker (1995) vindt de ondertitel passen bij de verhaalvorm van een raamvertelling: '[h]et geeft het verhaal een wat ouderwets, saga-achtig cachet, zou je kunnen zeggen; tenslotte heeft het als genre-aanduiding "een Iers verhaal” en Ierland, dat is uit zichzelf al iets uit een legende, nietwaar?'. Jaap Goedegebuure (1995) noemt de locatie 'raadselachtig' en vraagt zich af of die is ingegeven omdat 'een oud geloof wil dat de eilanden van de gelukzaligen zich ten westen van Ierland bevinden', of omdat 'het Keltische landschap de gewenste couleur locale [geeft] voor zoveel romantiek?'. Diny Schouten (1995) schrijft dat ze geen idee heeft wat een Iers verhaal is, afgezien van 'voor de hand liggende clichés', die ze verder niet toelicht en dus bekend veronderstelt; 'maar als het [een Iers verhaal] een beetje namaak is, is Phils obsessionele geilheid zeer echt'. Verder schrijft Schouten dat Van der Meers Ierse verhaal 'vol duistere driften' zit; het is 'een spookverhaal om aan volgende generaties door te geven'.

Getuige deze citaten roept Ierland in de Nederlandse verbeelding associaties op met sagen en legenden, ouderwetsheid, Kelten, romantiek, duistere driften en spookachtigheid. Het is duidelijk dat de critici ertoe neigen om de aandui-

\footnotetext{
${ }^{8}$ Haslam beschrijft hoe de term vanaf de jaren tachtig is gebruikt voor het werk van Ierse schrijvers als J.S. LeFanu, Charles Maturin en Bram Stoker, allen negentiende-eeuwse, protestantse, Anglo-Ierse schrijvers. Hun gotieke romans zijn gelezen als verbeeldingen van tegenstellingen die in Ierland aan de orde waren, zoals die tussen Brits en Iers, protestant en katholiek, kolonisator en gekoloniseerde. Zie bijvoorbeeld McCormack (1991), Backus (1999), Sage (2000), Killeen (2005), Kilfeather (2006).

${ }^{9}$ Ook Dorrestein bijvoorbeeld situeert een van haar gotieke romans in Ierland: Een sterke man (1994). Zie Hermans (1996) voor een analyse van Spookliefde en Een sterke man in termen van de tegenstelling tussen natuur en cultuur.
} 
ding 'Iers verhaal' als 'fantastisch' te lezen. De verwijzing naar een bestaand land, die als een realistische verwijzing begrepen zou kunnen worden, brengt de recensenten ertoe om juist weinig realisme te verwachten. Dat is precies de impuls die gotieke romans volgens Baldick en Mighall ten onrechte oproepen. $\mathrm{Zij}$ pleiten ervoor om geografische locaties van gotieke romans te lezen als teken van waarschijnlijkheid, als een teken van een historisch spanningsveld en niet als fantasie of escapisme. De vraag is dan voor welke spanning Ierland in Spookliefde de realistische setting kan vormen.

Goedegebuure vroeg zich af of Ierland was gekozen vanwege zijn Keltische associaties, maar Van der Meer activeert geen Keltische folklore in Spookliefde. Van druïden, elfjes of toverdranken is geen sprake. Net als veel oude gotieke romans waarover Baldick \& Mighall schrijven, heeft Spookliefde een realistische setting, want Ierland is nog altijd een (grotendeels) katholiek land. Dat katholicisme vormt het kader voor deze novelle, ook in letterlijke zin: op de eerste en de laatste bladzijde wordt een kaarsje gebrand, een katholiek ritueel. De vertelling wordt op verschillende niveaus in gang gezet - ontstoken, zou ik haast zeggen - door het herhaalde gebaar van het aansteken van een kaars in de kerk. De geschiedenis van de jonge Phil komt op gang doordat zij kaarsen brandt om Seamus' liefde te winnen. Ze wordt geconfronteerd met de dramatische gevolgen van haar wens als Seamus haar alsnog wil op een moment dat zij haar zinnen heeft gezet op Michael, maar ze haar wens niet heeft 'afgezegd'. De middelbare Phil wordt door een aangestoken kaars aangezet tot het vertellen van haar geschiedenis. Als ze het meisje vraagt waarom ze haar eigenlijk haar verhaal heeft verteld, zegt die: ' $U$ zag me de kerk uitkomen waar ik net een kaars voor Ian had opgestoken' (287). Het meisje dat kaarsen brandt voor haar vriendje Ian doet dat in de hoop op een vervolg van hun gedeelde (liefdes)geschiedenis.

De katholieke 'ontsteking' is dus van belang om het verhaal - de belevenissen van de jonge Phil, het vertellen van haar levensverhaal en de belevenissen van het meisje - überhaupt te laten gebeuren. Maar de katholieke setting is geen voedingsbodem voor een gotieke spanning tussen moderne heldin en haar archaïsche omgeving, zoals in oudere gotieke romans.

Volgens Baldick en Mighall worden we ons bewust welke moderne waarden precies onder vuur liggen in de gotieke roman, door te focussen op de anachronismen. In oude gotieke romans vormt een katholieke setting een realistisch decor voor het verbeelden van een conflict tussen een moderne, protestantse (Britse) identiteit en een archaïsche katholieke omgeving, waarbij de eerste zegeviert. Spookliefde brengt weliswaar een anachronisme in stelling - moderne heldin op archaïsch eiland - maar een religieus conflict is niet aan de orde, integendeel. Op het punt van het katholicisme is er juist sprake van een opvallende 
harmonie tussen heldin en haar omgeving. Katholicisme in Spookliefde heeft de vorm van kaarsen branden, een enkele mis en de verwijzing naar een verdronken bisschop. In vergelijking met die oude, in katholieke landen gesitueerde gotieke romans zijn corrupte monniken of wrede abdissen opvallend afwezig. Het eiland is weliswaar een archaïsche omgeving, maar de katholieke beeldtaal dient niet om een groter contrast tussen de gotieke omgeving en de moderne heldin te scheppen, integendeel. Hoewel Phil zonder twijfel een moderne heldin is, is zij zelf ook katholiek: ze bezoekt met haar ouders uit gewoonte de mis. Het naamloze meisje, vijfentwintig jaar later, is niet religieus, maar zij voelt zich op haar gemak bij het religieuze gebaar: 'Ik had nog nooit in een kerk een kaars opgestoken, maar het gebaar voelde niet vreemd, ongepast of afgekeken' (214). De katholieke elementen vormen dus geen tegenstelling met het moderne karakter van Phil en het meisje; ze zijn niet zozeer bedreigend of angstaanjagend, maar eerder empowering te noemen.

Phils moderne karakter wordt niet onderstreept door het af te zetten tegen een archaïsch katholicisme. 'Modern' is kennelijk de reformatie en - zo zou ik eraan toe willen voegen - de secularisatie voorbij. Dat is opvallend omdat, zoals Peter van Rooden schrijft: 'Over moderniteit wordt altijd gesproken door haar tegenover godsdienst te stellen.' (Van Rooden 2006, 10).

$\mathrm{Nu}$ is de maatschappelijke context waarin Spookliefde midden jaren negentig van de twintigste eeuw verschijnt natuurlijk een heel andere dan die van de oude gotieke romans. Gevoed door de massale ontkerkelijking vanaf de jaren zestig, is het dominante laattwintigste-eeuwse Nederlandse zelfbeeld te omschrijven als seculier. Even leek het alsof Nederland een van de weinige landen was waarvoor de secularisatiethese wél opging. ${ }^{10}$ Dat seculiere zelfbeeld vond een culminatiepunt in de jaren negentig, ten tijde van de paarse kabinetten Kok I en II, toen voor het eerst in bijna tachtig jaar zonder confessionele partij CDA geregeerd werd. Frans Ruiter en Wilbert Smulders (1996) noemen in hun literatuurgeschiedenis - die de moderniteit als uitgangspunt heeft - de 'drempels van verzuiling en ontzuiling' 'hét grote culturele drama van het Nederland uit de tweede helft van de twintigste eeuw' (Ruiter en Smulders 1996, 335). Schrij-

\footnotetext{
${ }^{10}$ Nederland is wat ontkerkelijking betreft koploper in Europa (Becker en Vink (1994), Kennedy (1995), p. 89 e.v). In de jaren negentig wordt wel een groeiende belangstelling voor religie waargenomen, maar die vertaalt zich niet in een toenemende kerkelijkheid (Becker en De Wit (2000)). Berger (1969) is de belangrijkste vertolker van de secularisatiethese, die stelt dat secularisatie het vanzelfsprekende neveneffect van modernisering is. Hij stelde later die verwachting bij (Berger 1999); kritiek op de secularisatiethese levert Van Rooden (2006), p. 9-15. Zie Koenis (2008), p. 135-154, voor een uitvoerig overzicht van literatuur over moderniteit en secularisatie.
} 
vers als Oek de Jong, A.F.Th. van der Heijden, Frans Kellendonk en Maarten 't Hart hebben volgens hen 'in belangrijke mate het beeld bepaald dat van dat drama in de cultuur heeft postgevat.' (Ruiter en Smulders 1996, 335). Dat drama is in de jaren negentig wel uitgewoed: het hoogtepunt van de schrijvers die Ruiter en Smulders noemen ligt daarvoor. De Nederlandse literatuur is dus van groot belang geweest voor het (zelf)beeld van een ontzuilde samenleving. Ook het omgekeerde geldt, zou ik eraan toe willen voegen: een geseculariseerd zelfbeeld is van groot belang geweest voor de literatuur. Religiositeit leek hooguit in de streekliteratuur nog een plek te hebben. Literaire auteurs die wel over religieuze overtuigingen schreven werden op dat punt nauwelijks serieus genomen. ${ }^{11}$

Mijn vraag was hoe Ierland fungeert als gotieke setting in een Nederlandse roman uit de jaren negentig. Ik constateerde dat Ierland een realistische setting is voor de katholieke rituelen in de roman. Ierland is ook in de jaren negentig een land met een katholiek signatuur. Het is daarmee - anders dan Nederland waar het seculiere zelfbeeld inmiddels dominant geworden is - een waarschijnlijke literaire setting om de vanzelfsprekendheid van religieuze gevoelens vorm te geven. De vanzelfsprekendheid - want op het punt van het katholicisme is er geen anachronistisch contrast tussen heldin en haar omgeving. Van der Meers keuze voor Ierland is een keuze voor een anti-seculiere setting. Dat is niet toevallig gezien haar biografie. Van der Meer trad halverwege de jaren negentig toe tot de katholieke kerk, dus rond het verschijnen van Spookliefde. Dat werd pas jaren later bekend bij het grote publiek, bij de verschijning van haar volgende roman Eilandgasten (1999). Terwijl het katholicisme in Spookliefde, in een Ierse context, geen enkele reactie van recensenten oproept (zie de eerdere citaten), doet (het vermoeden van) katholicisme in een Nederlandse context dat wel, getuige de reacties op Eilandgasten. ${ }^{12}$ Daarmee is de vraag wat dan wel een bron van het gotieke is in Spookliefde nog onbeantwoord. Als het katholicisme geen

\footnotetext{
${ }^{11}$ Ruiter en Smulders lijken Reves bekering bijvoorbeeld voornamelijk op te vatten als een literair spel: 'Reve gebruikt in de jaren zeventig de dan oudmodisch geworden katholiciteit om op literaire wijze de sporen uit te wissen van zijn communistische jaren veertig-jeugd' (323-324). Goedegebuure (1989) en Eugelink (2007) zien wel een serieus te nemen religieuze onderstroom in de literatuur.

${ }^{12}$ Max Pam schrijft bijvoorbeeld: '[D]e laatste jaren zijn er nogal wat berichten dat Van der Meer theologie is gaan studeren en dat zij als consequentie daarvan katholiek is geworden. O jee, denk je dan al snel als doorgewinterde atheïst, als dat maar goed gaat. Eilandgasten, de nieuwe verhalenbundel van Van der Meer, leek me daarom een uitstekende gelegenheid om mijn ongerustheid, alsmede mijn (gezonde) vooroordelen jegens de religie, nog eens te testen.' Ook de toetreding van Van der Meers man, Willem Jan Otten, die daarvan publiekelijk verslag deed (Otten 1999), maakte veel (kritische) reacties los onder columnisten en recensenten.
} 
element is in de anachronistische spanning tussen heldin en omgeving, wordt dan op een andere manier een frictie tussen moderniteit en traditie verbeeld?

\section{VROUW MET HOUTEN ONDERLIJF}

Spookliefde speelt zich niet af in een specifiek jaar, en er zijn ook geen verwijzingen naar herkenbare historische gebeurtenissen. ${ }^{13}$ Ondanks het ontbreken van een precieze historische context is het anachronisme - dat Baldick en Mighall zo kenmerkend achten voor de gotieke roman - duidelijk te herkennen. Er is in Spookliefde een contrast tussen de moderne heldin Phil en het archaïsche eiland. In de beschrijvingen van Phils achtergrond zijn typisch twintigste-eeuwse, naoorlogse fenomenen te herkennen. Phil komt uit de Verenigde Staten, icoon van de moderniteit. Het land wordt met enkele steekwoorden - cheerleaders, musicals en drive-in bioscopen - neergezet als een plek waar iets te doen is voor jongeren. Kansas, de staat waar Phil vandaan komt, kan moeilijk als meest progressieve of hippe plek in de VS beschouwd worden, maar het contrast met het eiland is niettemin enorm. Daar brandt men nog turf en er is slechts één telefoon.

Het verleden is voelbaar aanwezig op het eiland, en het onderscheid tussen verleden en heden is vaag. Phils vader vertelt haar een verhaal over een bisschop die eeuwen eerder bij een klif werd gemarteld en verdronk, waarop Phil denkt: 'Het leek haar geen goed teken dat hij iets van zo lang geleden vertelde op een toon alsof het gisteren was gebeurd' (223). De vleermuisachtige, zwarte omslagdoek die Phil van haar oma meekrijgt naar het eiland is een ander voorbeeld van het onduidelijke verschil tussen heden en verleden. Dit symbolisch geladen kledingstuk speelt een cruciale rol in het plot, overigens net als in Vriend van verdienste: het is de oorzaak van een fatale persoonsverwisseling. Phils moeder vindt de doek niet geschikt voor jonge meisjes, waarop Phil zegt: "'Oma zei dat alle vrouwen op de eilanden zo'n doek dragen". "In de vorige eeuw misschien", antwoordt haar moeder. "Deze eeuw, de vorige eeuw, maakt dat dan wat uit hier?"' (224), vraagt Phil. De doek is kennelijk te ouderwets voor een meisje als Phil, althans volgens haar moeder: het is een anachronistisch object. Terwijl

\footnotetext{
${ }^{13}$ Via de leeftijden die her en der wel expliciet vermeld worden valt een generatie-tijdlijn te schetsen. Phil is in de veertig als ze haar verhaal aan het meisje vertelt, ze was zeventien toen ze op het eiland aankwam en haar vader was toen vijftig. Hij emigreerde als achtjarig jongetje van Ierland naar de Verenigde Staten. Rekenen we terug vanaf de verschijning van Spookliefde (1995) dan zou Phil rond 1950 geboren zijn en haar vader rond 1928, maar het vertelde valt niet als zodanig in de tijd te situeren.
} 
Phil zich bozig afvraagt of het eiland wel met de tijd is meegegaan, maakt haar moeder een scherp onderscheid tussen (ouderwets) verleden en (modern) heden.

Phil heeft sterk het gevoel dat haar ouders (Amerikanen van Ierse afkomst) een fout begaan hebben door de Verenigde Staten achter zich te laten:

Phil streek met haar tong langs haar tanden. 'Op zo'n eiland zul je nooit een man vinden,' had oma gezegd. Ieder uur dat ze hier langer was werd het haar duidelijker: haar ouders waren de verkeerde kant op geëmigreerd. (226)

Haar gevoel dat ze verkeerde richting op is gereisd, dat ze teruggaat in de tijd, spitst zich toe op een specifiek onderwerp, getuige dit citaat. Een cruciaal aspect van de moderne Amerikaanse samenleving die Phil heeft verlaten is de mogelijkheid voor meisjes om met seks te experimenteren. Thuis in de Verenigde Staten was ze jaloers op haar wereldwijze vriendin Susie, die de motorkap van een jongen vol scheerschuim had gespoten, en met een jongen naar bed was geweest in een motel. Vlak voor Phils vertrek naar het eiland mocht haar beugel eruit, zodat letterlijk niets meer in de weg stond om haar verlangens te vervullen: 'Vroeger kon ze zichzelf nog wijsmaken dat het door haar beugel kwam dat ze nooit een vriend had gehad.' (227). Phil is een moderne jonge vrouw, en het is duidelijk wat ze wil: seks. 'Ze brandde van nieuwsgierigheid erachter te komen hoe het voelde, een kus en al die andere dingen die Susie Dwyer al zeker een jaar met jongens deed' (244). De waarschuwing van haar oma, die achterblijft in de VS, maakt duidelijk dat het eiland een belemmering zal vormen voor het vervullen van haar wensen. Zo modern als Amerika is, zo achtergebleven is het eiland. Phil is te modern, ze valt teveel uit de toon. In de ogen van de eilandbevolking is ze niet alleen vreemd maar onecht, zoals blijkt uit de vraag van meisjes van het eiland of haar tanden echt zijn: 'Ze zijn zo recht, ze lijken wel van plastic' (238). Haar regelmatige gebit, bedoeld als wapen van verleiding, wordt op het eiland niet als zodanig herkend.

Phil is zich bewust van deze obstakels. Vanaf het moment dat ze op het eiland aankomt heeft ze sterk het gevoel dat ze door iets wordt achtervolgd (denk aan het eerdere citaat over de tunnel) en voelt ze zich opgesloten. Ze vertelt het meisje hoe ze op een van haar eerste wandelingen over het eiland een vrouw in de deuropening van haar huis zag staan, die over de onderdeur leunde. De vrouw stond er nog toen Phil terugkwam van haar wandeling. 'Die vrouw met het houten onderlijf was haar schrikbeeld geworden, zo zou het haar ook vergaan als ze niet bijtijds wegkwam' (244, cursivering AA). Dit schrikbeeld, 
een woord dat in het Engels wordt vertaald als 'spectre' (spook) is de eerste betekenis van spookliefde: een liefde die net als een spook nooit werkelijkheid wordt, die niet gematerialiseerd wordt. Dat geldt zowel voor Phils liefde voor Seamus als voor Michael: met geen van beiden wordt de liefde geconsumeerd. Het sterke beeld van het houten onderlijf suggereert al dat liefde hier in de eerste plaats als lichamelijke liefde moet worden opgevat. Het eiland staat voor stagnatie die onherroepelijk zal uitmonden in de dood, al heeft die iets verleidelijks:

Als ze hier niet snel wegkwam, zou het haar vergaan als de schapen met hun gebonden poten. Eens in de zoveel tijd stortte er een van een klip, 'per ongeluk' zei haar vader, maar Phil wist zeker dat ze zich met opzet de diepte in lieten vallen omdat ze geen weerstand konden bieden aan het witte schuim dat als een grote schapenvacht op het water dreef. (228)

Phil wordt achtervolgd door een verlangen naar seks, of misschien preciezer gezegd door een angst voor géén seks. Gebrek aan seks zou haar doen veranderen in een afschrikwekkend (monsterlijk) beeld: de vrouw met het houten onderlijf; of anders in een dood schaap. Daarmee onderscheidt ze zich van haar voorgangsters uit de gotieke roman.

In het Radcliffeaanse plot is de gotieke heldin een persecuted maiden: een moderne jonge vrouw die belandt in een archaïsche omgeving en wordt belaagd door sinistere mannelijke opponenten, vaak oudere, vaderachtige figuren. Moderne burgerlijke waarden worden bevestigd, aldus Baldick en Mighall, wanneer deze heldin haar maagdelijkheid weet te redden en fatsoenlijk kan trouwen met de vrijer van haar keuze, zoals Ellena in Radcliffes The Italian (1797). Als de heldin haar maagdelijkheid voortijdig verliest, zoals Antonia in Lewis' The Monk (1796), die verkracht wordt door de monnik Ambrosio, is ze 'verloren' voor het verhaal en sterft. Phil is een ander soort heldin dan haar achttiendeeeuwse voorgangsters. Om een fatsoenlijke entree in de maatschappij is het haar niet te doen. Phil wil haar 'eerste keer' meemaken, zij wil niets liever dan haar maagdelijkheid verliezen.

Schouten merkte in haar recensie op dat Phils 'obsessionele geilheid' zeer overtuigend is. De vanzelfsprekendheid van zulke vrouwelijke lust, en de vastbeslotenheid die Phil tentoonspreidt om die uit te leven, zijn een relatief recente verworvenheid. Tot in de jaren zestig van de twintigste eeuw werd door wetenschappers aangenomen dat vrouwen minder seksuele verlangens kenden dan 
mannen. ${ }^{14}$ Van vrouwen werd een afwachtende, passieve houding verwacht, zeker ook in katholieke kringen, waar seksualiteit alleen de voortplanting moest dienen en vrouwelijke lust geen thema was. ${ }^{15}$ Lustvolle vrouwen werden in kunst en literatuur vaak afgebeeld als monsterlijk, of worden gestraft (Dijkstra 1986, 1998).Onder invloed van de seksuele revolutie, maar vooral de tweede feministische golf, kwam er meer aandacht voor seksuele verlangens van vrouwen. ${ }^{16}$

Phil is zo'n moderne jonge vrouw, die zich bewust is van haar seksuele verlangens. Haar doelgerichte verlangen lijkt weliswaar misplaatst op het eiland, maar zij wordt niet als monsterlijk gerepresenteerd. So far so good. Phil slaagt er echter niet in haar ontmaagding te arrangeren. Volgens Mighall worden de spanningen in de gotieke roman tussen modern en traditioneel, vooruitstrevend en achterlijk op scherp gezet en meestal in het voordeel van het moderne individu beslist. Hoewel in Spookliefde de tegenstelling modern en traditioneel aanvankelijk scherp is, is de uitkomst niet zo duidelijk. Aan het eind van de roman wordt Phil niet 'beloond' met een nacht met de minnaar van haar keuze. Michael is dood, Seamus gaat naar de gevangenis, en als hij terugkeert is hij even stom als Michael eerst was. Phil trekt aan het kortste eind. Dat het Phil niet om

\footnotetext{
${ }^{14}$ In de negentiende eeuw kwam zelfs het idee dat vrouwen seksuele wezens waren ter discussie te staan, zie Laqueur (1990), p. 189-190. Onder anderen de Britse gynaecoloog William Acton (1857) en de Duitse Otto Adler (1904) ontkenden de vrouwelijke lust. Hun opvattingen werden weliswaar bestreden, maar 'toch kreeg toen en later de figuur van de onvermijdelijk frigide vrouw meer aandacht dan zij verdiende' (Gay 1988, 465). Nog in 1955 schreven Walker\& Fletcher in hun populaire studie Sex and Society: 'the sexuality of adolescent girls is more likely to express itself in romantic than in erotic feelings' (met dank aan Henk de Smaele). Pas door het beroemde onderzoek van Alfred Kinsey (1953), later gevolgd door Shere Hite (Sexual Honesty by women, for women (1974) en The Hite Report on Female Sexuality (1976), kwam wetenschappelijke 'erkenning' voor vrouwelijke lust, al stelde de Duitse feministe Alice Rühle-Gerstel al in de jaren dertig dat de clitoris het belangrijkste vrouwelijke lustorgaan is. In Nederland hield het tijdschrift Margriet in 1968 een enquête over seks in Nederland. De resultaten en de vergelijking met een onderzoek uit 1981 zijn te vinden in G.A. Kooy, Sex in Nederland: Het meest recente onderzoek naar houding en gedrag van de Nederlandse bevolking (Utrecht/Antwerpen: Spectrum, 1983).

${ }^{15}$ Het volkomen huwelijk (1923, 26 herdruk in 1972) van de seksuoloog Th. H. van de Velde was een standaardwerk, in Nederland en daarbuiten, waarin de vrouw als vanzelfsprekend passief is. De rollen in bed mogen af en toe worden omgedraaid - de vrouw mag wel eens boven liggen , maar het mag geen gewoonte worden: 'Als nadeel zou echter, bij onbeperkte toepassing, de volledige passiviteit van den man en het verplaatsen van de volle activiteit naar de vrouw, moeten worden beschouwd, omdat het in strijd is met de natuurlijke verhoudingen der sexen' (geciteerd in Meulenbelt 1979, 88).

${ }^{16}$ In Nederland bijvoorbeeld door de publicaties van de NVSH (zie ook hoofdstuk 4) en van feministische auteurs, bv Anja Meulenbelt, Voor onszelf. Vanuit vrouwen bekeken: lijf en seksualiteit (1979) of Ariane Amsberg, Wat vrouwen zelf van seks vinden (1977).
} 
een huwelijk te doen was blijkt nog eens uit haar terloopse opmerking dat ze trouwde en kinderen kreeg nadat ze het eiland had verlaten.

Mighall (en ook Baldick \& Mighall) besteedt in zijn historische benadering van het gotieke nadrukkelijk geen aandacht aan gender, met het argument dat 'questions of gender are, if not explicitly psychological, then premised largely upon ontological considerations (the issue of 'subjectivity)' (Mighall 1999, xxi). Daarmee gaat hij voorbij aan de constituerende kracht van genderaspecten bij elke identiteit, ook nationale (Britse) of religieuze (protestantse) identiteiten. In de achttiende-eeuwse gotieke romans is het gotieke bevestigend voor een protestantse identiteit, maar ook voor een genderidentiteit, zou ik eraan toe willen voegen. De verwachte deugdzaamheid van vrouwen wordt erin bevestigd. Mighall miskent de historische aspecten van het genderbegrip. Betekenissen van gender en seksualiteit zijn historisch veranderlijk. In de vorige hoofdstukken heb ik laten zien hoe juist de culturele spanningen rond veranderende opvattingen over homoseksualiteit, mannelijkheid en vrouwelijkheid voer voor de gotieke verbeelding vormen. Ook in Spookliefde is dat het geval. Phils actieve seksuele verlangen is een aspect van moderne vrouwelijkheid. Het anachronistische gegeven leidt echter niet tot een bevestiging van moderne seksuele verworvenheden: Phil krijgt het niet zoals ze het wil hebben. Dat ligt onder andere aan de heldin zelf, die geacht wordt deze waarden te representeren. Het anachronistische conflict verplaatst zich naar binnen.

\section{SEKS TOT (W)ELKE PRIJS}

In Spookliefde krijgt in eerste instantie een conflict tussen moderne Phil en haar traditionele omgeving vorm, maar dat conflict verplaatst zich naar binnen. Ze arriveert op het eiland als een meisje dat maar een ding wil: seks. Die ondubbelzinnige begeerte maakt plaats voor twijfels en ambivalentie, allereerst doordat de jongen van haar keuze een tweeling blijkt. Hoe doelgericht kun je zijn als het object van verlangen zich splitst? Zo weet Phil op een zeker moment 'niet [...] wie deze opwinding veroorzaakte, Seamus of Michael' (252). Haar eigen verlangen is bovendien ambivalent: enerzijds wil ze graag initiatief nemen, anderzijds wil ze het initiatief graag uit handen geven. Tenslotte betwijfelt ze haar verlangen zelf: wil ze misschien toch iets anders dan seks?

Om met dat laatste punt van twijfel te beginnen: als Phil met de zwakbegaafde Michael begint op te trekken, raakt ze geïntrigeerd door zijn zwijgzaamheid, en door de natuur die hen omringt. Michael is een onnozele - in diverse betekenissen van het woord: een idioot, een onschuldig kind - en Phil is daar 
ontvankelijk voor. Ze leert het eiland zien door zijn ogen, en ervaart het als een soort paradijs waarin zij tweeën als de eerste mensen rondlopen, namen gevend aan de planten en de dieren om hen heen. Het eiland krijgt met andere woorden vat op Phil - het anachronistische contrast tussen haarzelf en het eiland vervaagt. Door de harmonieuze band met Michael begint ze te twijfelen aan haar verlangen. Ze vreest 'dat de begeerte teveel zou veranderen - niet alleen hun maagdelijke lichamen, henzelf, hun vriendschap maar dat ook het eiland daarna niet langer het paradijs zou zijn dat het nu was' (260).

De christelijke connotaties zijn niet toevallig: juist het contact met Michael roept bij Phil religieuze vragen op. In een sleutelscène van de roman zit ze met Michael op de rotsen. Michael zit kokkels kapot te slaan met een steen en dat doet Phil denken aan de willekeur van het lot: 'Ze vroeg hem of hij zich wel eens afvroeg wat er achter de sterren was en daar weer achter. Of hij geloofde in een God die hen beschermde maar ook in een klap kon vermorzelen' (258259). Het is een vooruitwijzing naar het eind, naar het willekeurige lot dat Michael zal treffen, want het is min of meer toevallig dat híj sterft, en niet Phil. De vraag is te abstract voor Michael, maar hij reageert alsnog als ze even later een vrouw zien die een laken aan de waslijn hangt: '[de vrouw] spreidde haar armen zo wijd mogelijk om het laken strak te trekken, toen een windvlaag het tegen haar aan blies. Door de stof heen zag je vaag de contouren van haar lichaam. "Engel," riep Michael precies op dat moment, en hij wees' (259).

Deze engel is het enige bovennatuurlijke wezen dat in Spookliefde genoemd wordt. ${ }^{17}$ Geen spook, maar een engel. Michael maakt hier duidelijk dat wat hem betreft de typische kledij van een engel identiek is aan die van een spook: een wit laken. Spoken en engelen hebben gemeen dat ze bovennatuurlijke wezens zijn. De gotieke roman heeft patent op de aanwezigheid van transcendente wezens zoals spoken. Een spook is op te vatten als een anachronistisch verschijnsel, wat zijn gotieke effect verklaart: het hoort thuis in het verleden, maar duikt op in het heden en zorgt zo voor een spanning tussen (gotiek) verleden en (modern) heden. In Spookliefde wordt het contrast tussen heden en verleden op het eiland juist afgezwakt, zoals ik hierboven betoogde. Het bovennatuurlijke in deze gotieke roman krijgt geen angstaanjagende betekenis, maar een positiefreligieuze invulling. Hier stuiten we op de tweede betekenis van spookliefde: de liefde voor het bovennatuurlijke; voor het spook c.q. engel die hier via het laken gestalte krijgt.

\footnotetext{
${ }^{17}$ Hier zie ik opnieuw een parallel met Noorderzon: daar verandert Topaas uiteindelijk in een engel, of in een vogel.
} 
Het laken is echter geen eenduidig beeld; het echoot eerdere passages in Spookliefde: 'Het was een avond om naakt te gaan slapen met alleen een laken over je heen, een laken of een naakt lichaam' (246). Susie heeft Phil verteld dat de jongen met wie ze naar bed ging na afloop op haar in slaap viel, maar dat na het vrijen 'niets meer zwaar was' (246). Phils avond eindigt veelzeggend met: 'ze trok het laken tot aan haar kin' (252). Het laken, dat niet alleen naar een engel verwijst maar ook de contouren van het vrouwenlichaam zichtbaar maakt, krijgt dus ook seksuele connotaties. Zo wordt in een beeld samengebald waar deze roman om draait: de spanning tussen seksueel en religieus verlangen. ${ }^{18}$

Phils verlangen laat zich namelijk niet stillen door het paradijselijke eiland. Ze wijst Seamus terecht die vindt dat ze zich om zijn broer bekommert als een jonge moeder: 'niks Maria, niks moederlijks, niks heiligs' (268). Phil stuurt aan op haar ontmaagding door Michael. Een volgende bron van ambivalentie is de vraag bij wie het initiatief ligt. Phil doet Michael voor hoe hij moet dansen, hoe hij zijn armen om haar heen moet slaan, hoe hij haar moet aaien: 'Ze kon hem alles laten doen, alles wat en wanneer ze maar wilde' (251). Zijn volgzaamheid wekt echter haar teleurstelling: 'Tot nu toe waren alle aanrakingen zo toevallig, terloops' (257). Als Phil van iemand hoort dat Seamus en Michael elke maand naar de hoeren gaan op het Ierse vasteland is ze verontwaardigd, maar tegelijkertijd stijgt Michael juist in haar achting. Het maakt hem minder onschuldig dan hij lijkt. Phil verklaart zijn terughoudendheid uit de traditionele ideeën over seks op het eiland, wat het contrast tussen haarzelf als modern en het eiland/Michael als arachaïsch accentueert: 'Al die tijd had hij haar niet durven aanraken, omdat het niet mocht. Eerst van zijn ouders niet, van de pastoor niet en nu van Seamus niet, zoiets deed je niet met een net meisje. Zo ging dat hier, nog steeds, maar zij zou hem van die dorpse denkbeelden verlossen' (261). Door zichzelf te positioneren als de prostituee probeert ze Michael tot actie aan te zetten: 'Wat je met Gladys doet, kun je toch ook met mij doen?' (261)

De teleurstelling over Michaels gebrek aan initiatief wordt afgewisseld door angst over wat hij met haar zou kunnen doen. Phil wordt bang gemaakt voor Michael door de meisjes van het eiland, die zeggen dat hij heel sterk is en ook gevaarlijk zou kunnen zijn, want 'je wist het maar nooit met zo'n jongen' (245). Als ze haar pols verbrand heeft, vraagt Seamus opvallend bezorgd of iemand haar ruw behandeld heeft (238). Ook haar ouders waarschuwen haar: 'hij mocht dan wel kinderlijk zijn maar hij was een man, met mannelijke driften'

\footnotetext{
${ }^{18}$ In termen van de interpretatietheorie van Riffaterre (Semiotics of Poetry, 1978) zou je het laken een hypogram noemen: een overgedetermineerd woord in de tekst dat nieuwe betekenissen ontsluit (zie Meijer 1988 voor een toepassing van Riffaterre).
} 
(257). Phil stelt zichzelf gerust dat Michael niet gevaarlijk is, maar ondertussen twijfelt ze: 'Hij had nog nooit een meisje van het eiland lastig gevallen, toch bleven ze maar uit zijn buurt - dat was niet voor niets' (252). Als ze na een verlovingsfeestje met hem naar huis loopt is ze bang: 'Ze zag voor zich hoe hij de doek van zijn schouders trok en om haar hals wikkelde, veel te strak en dingen met haar deed die ze niet wilde maar ook niet kon verhinderen' (254).

Phil wil verlangd worden, zij het niet tegen elke prijs: ze wil wel belaagd worden, maar niet verkracht. De veronderstelde dreiging die van Michael uitgaat wordt in de tekst gemarkeerd door een opvallende breuk - de enige - in de chronologische volgorde van Phils vertelling aan het meisje: in een scène die suggereert dat Phil haar maagdelijkheid heeft verloren. Direct na de beschrijving van Phils eerste dans met Michael op een verlovingsfeest, vervolgt de tekst met: 'Ze trok het laken tot aan haar kin [...]. Het koude water waarmee ze haar benen en dijen had gewassen was bijna opgedroogd. Morgen zou ze een douche nemen, haar onderbroek uitwassen en zijn zakdoek' (252). De suggestie van deze zinnen is dat Phil seks heeft gehad met Michael, maar even later blijkt dat niet het geval: ze heeft in haar broek geplast van angst. Na het feest kwam ze Michael tegen het donker, en was ze plotseling bang omdat ze zich de verhalen van de eilandmeisjes herinnerde. Het dreigende geweld wordt met gotieke beelden gerepresenteerd: Michael komt op Phil afgerend 'met een grote fladderende cape', als een 'immense vleermuis' (254), en voordat ze zich realiseerde dat hij haar eigen omslagdoek droeg, had ze in haar broek geplast. Ze was bang dat hij haar zou overweldigen, maar het enige wat hij deed was zelf tegen een muurtje plassen. De nadrukkelijke verwarring die in deze passage wordt gewekt over angst en verlangen - is er nu gebeurd wat Phil vreesde of wat ze wilde? - toont Phils ambivalentie.

Over de combinatie van vrees en verlangen is in de literatuur meer dan eens gefilosofeerd. De ambivalente gevoelens van Phil laten zich goed beschrijven aan de hand van wat filosofe Marjan Slob (2007) schrijft over romantische verhalen. $\mathrm{Zij}$ onderzoekt in een prikkelend essay haar plezier in 'foute fantasieën', zoals zij ze noemt: fantasieën waarin een dominante man een vrouw overrompelt, de formule waar romantische verhalen zoals die uit de Bouquetreeks op drijven. Het plot van Spookliefde is in feite een variatie op het romantische plot, met dat verschil dat Phils belangrijkste verlangen - romance in zijn moderne vorm, dat wil zeggen liefde inclusief seks - niet wordt vervuld. ${ }^{19}$ Slob vraagt zich af hoe het mogelijk is dat zij, als feministische vrouw die de gelijkwaardige posi-

\footnotetext{
${ }^{19}$ Nadat dit hoofdstuk werd afgerond verscheen Botting (2009), die de geschiedenis van en dwarsverbanden tussen het gotieke en de romance beschrijft.
} 
tie van mannen en vrouwen hoog in het vaandel heeft, zich van tijd tot tijd zo graag wil verliezen in zulke vrouwonvriendelijke fantasieën. Haar antwoord is dat romantische fictie een oefening in ontvankelijkheid biedt: 'De romantische fantasie wijst op het belang van ontvankelijkheid, het vermogen gevoelig te blijven voor wat je nog niet weet en nog niet kent, voor wat jou ontstijgt' (148).

Slob vergelijkt de romantische fantasie met de manier waarop musici en drugsgebruikers toewerken naar het beleven van hun passie. Hoewel beide groepen volop handelen om hun doel te bereiken, valt de ervaring zelf - de vervoering door muziek of een shot - niet af te dwingen: 'om sommige dingen mee te maken, moet je je passief durven opstellen' (Slob 2007, 147). Dat geldt nu ook voor de romantische ervaring. Omdat er gemiddeld genomen een reëel verschil in fysieke kracht tussen mannen en vrouwen is, aldus Slob, is het risico van zo'n romantische ontmoeting voor vrouwen groter dan voor mannen: 'romantische fictie erotiseert omdat zij speelt met het spanningsvolle verschil tussen "echte" mannen en "echte" vrouwen' (141). De heldin van het romantische verhaal toont de moed om passief te zijn:

Daar zit ze, wachtend, vervuld van een vaag onbehagen. Ze heeft geen duidelijke voorstelling van wat het is waar ze op wacht. Het heeft iets met seks te maken, dat voelt ze wel, maar het is meer dan seks. Ze verlangt naar een man die haar iets zal tonen wat ze nog niet kent. [...] Die man zal haar initiëren. Hij zal haar in aanraking brengen met het sublieme. [...] Ze weet niet precies wat ze moet doen en ze weet niet precies wat ze kan verwachten. Maar ze weet dat ze onvervuld is, en dat ze bereid moet zijn om de sprong in het onbekende te wagen. (146)

Het idee dat overgave een manier is om vervulling te vinden is een typisch Romantisch idee. Slob citeert Maarten Doorman, die stelt dat wij nog altijd in 'de romantische orde' leven, waarin het paradoxale streven is om 'geheel jezelf te worden door je juist in de ander te verliezen, je eigen identiteit te ontwikkelen door die goeddeels prijs te geven.' (Doorman geciteerd in Slob 2007, 99). Dat paradoxale streven ziet er voor mannen wel heel anders uit dan voor vrouwen. Phil in Spookliefde is op zoek naar zo'n romantische ervaring. Maar haar doelgerichtheid - die moderne verworvenheid - wringt met de passiviteit die volgens Slob noodzakelijk is. Phil wil de omstandigheden naar haar hand zetten. Ze probeert Michael te sturen door hem voor te doen hoe hij zich moet gedragen. Als er weer een feest in het dorp is heeft ze haar plan klaar. Ze zegt Michael dat hij naar haar kamer moet gaan en op haar moet wachten, wat hij braaf doet. Haar ouders, die haar keuze voor Michael afkeuren, houdt ze voor dat ze voor 
Seamus zal kiezen. Ook Seamus brengt ze in die waan door hem te beloven dat ze met hem zal dansen op het feest.

Haar manipulaties zijn een manier om haar eigen verlangen staande te houden tegenover Seamus en haar ouders, 'al die mensen die zo precies wisten wat goed voor haar was' (276). Voor hen is haar verlangen niet maatgevend. Seamus komt buiten Phil om bij Phils vader om haar hand vragen, en haar ouders keuren haar keuze voor Michael openlijk af: 'We zijn niet bekrompen. Een neger, een jood, een protestant desnoods of iemand met een licht gebrek maar verder goed bij zijn hoofd. Maar dit' (273). Phils ouders presenteren zichzelf als modern, maar willen wel voor hun dochter beslissen. Het resultaat is averechts, zoals blijkt uit Phils gedachten over haar vader: 'Hij moest niet gaan zeggen wat ze voelde, wilde en niet meer wilde - dan kreeg ze de neiging om precies het tegenovergestelde te willen' (247). Phils doelbewuste streven naar autonomie, naar vervulling van háár verlangen, los van ouders en omgeving, verhoudt zich moeizaam tot ontvankelijkheid. Dat is precies het dilemma van de moderne vrouw, zoals Slob duidelijk maakt en zeker van de katholieke moderne vrouw.

Slob noemt het beleven van de passie een sublieme ervaring, omdat die een risico inhoudt, vooral voor vrouwen. ${ }^{20}$ Ze moet pijn riskeren, ze moet haar drang tot zelfbehoud tijdelijk opgeven. De romantische heldin ervaart het sublieme in het contact met een overweldigende man: dat levert een combinatie op van huiver en heerlijkheid, pijn en verrukking. Bij de sublieme ervaring hoort 'het gevoel een plaats te krijgen, anngesproken te worden door iets of iemand die of die je een richting geeft', zo citeert Slob de filosofe Renée van de Vall (Slob 2007, 94).

Phil ervaart het riskante karakter van haar verlangen maar al te goed als ze na het eerste feest met Michael naar huis loopt. Dan voelt ze dat ze in zijn macht is, dat ze de controle kwijt is. Gegrepen door een verlammende angst doet ze het in haar broek. Haar angst leidt niet tot verrukking, niet tot een romantische of sublieme ervaring. Wat ontbreekt moge duidelijk zijn: Michael richt zich niet tot Phil, hij spreekt haar niet aan - letterlijk, want hij spreekt immers nauwelijks. Ze krijgt van hem geen richting, integendeel, ze probeert zelf richting te geven, uiteindelijk tegen beter weten in. Haar ultieme poging hem tot daden te bewegen is wanneer ze hem in haar kamer op haar laat wachten en zorgt voor kaarslicht, bier en muziek. Als zij arriveert slaapt hij, wat een

\footnotetext{
${ }^{20}$ Het sublieme is door Edmund Burke (1757) omschreven als een esthetische ervaring die met angst gepaard gaat, volgens Burke de sterkste emotie waartoe de menselijke geest in staat is. De gotieke roman, met zijn imponerende landschappen, overweldigende weersomstandigheden en indrukwekkende gebouwen geldt bij uitstek als plek waarin het sublieme kan worden gerepresenteerd. (in Clery \& Miles 2000, 112-121).
} 
gotiek tafereel oplevert waarin het lijkt 'alsof Michael schijndood in een kapel op haar lag te wachten' (277). Hoezeer ze ook haar best doet hem te verleiden door een striptease voor hem op te voeren, Michael is passief; hij imiteert alleen, hij heeft geen eigen verlangen. Gladys, de prostituee, bevestigt dat na Michaels dood: 'sommige mannen hebben het niet, die aandrift, zal ik maar zeggen' (284). Hoe romantisch de setting ook is, er komt geen romantische ervaring uit voort.

Er is een ander moment in de roman waarop Phil een overweldigende ervaring heeft, net zomin romantisch als de eerste. Wanneer ze ontdekt dat er niet één jongen is met verschillende eigenschappen, maar dat het een tweeling is, ervaart ze dat als een verlies van controle: 'Haar knieën knikten, alsof ze op een podium stond voor een auditie. Haar armen werden loodzwaar, ze verloor de beheersing over haar spieren omdat ze tegelijkertijd op de tribune zat en naar zichzelf keek, zag hoe ze daar stond met knikkende knieën en armen die de muziek niet meer volgden.' (241). De verdubbeling van haar liefdesobject leidt tot een verdubbelde ervaring van zichzelf, een moment lang valt ze niet meer met zichzelf samen, maar ziet zichzelf als vanaf een tribune. De overweldigende ervaring van verlies moet wel veroorzaakt worden doordat ze niet meer weet op wie ze haar verlangen gericht heeft.

Phil moet opnieuw de richting van haar verlangen bepalen. Eerder had ze van Seamus geleerd dat richting er niet toe deed, toen hij een ballade zong 'over een jongen die uit Ierland wegtrok om zijn geluk te beproeven, aan de overkant, in Amerika' (228). Phil ervoer dat het niet uitmaakte dat het lied ging over heimwee naar Ierland, terwijl ze zelf heimwee had naar Amerika. Het gevoel was hetzelfde, los van de richting: 'Het verlangen was hetzelfde' (229). Maar het is problematisch als een en hetzelfde verlangen zich op twee mannen gericht blijkt in plaats van een. Ze moet kiezen.

De tweelingbroers lijken op elkaar, maar zijn verschillend. Als Phil staat bij te komen van de ontdekking dat er twee broers zijn denkt ze over gelijkenis en verschil na: '.. dat dingen soms heel erg op elkaar leken, golven op dieren, wolken op draken, en toch niet hetzelfde waren?' (242). Dit is het mechanisme van een metafoor, die een verband legt tussen twee verschillende dingen op grond van een gelijkenis die het verband motiveert. De broers zijn fysiek identiek maar toch verschillend en dus eerder het omgekeerde van een metafoor: twee identieke dingen die een verschil markeren. Wat Phil eerst een en dezelfde man met twee verschillende kanten leek - soms zong de blonde man, soms was hij zwijgzaam -, blijkt het verschil tussen twee mannen. Dat verschil betreft vooral hun taalvermogen. 
Michael spreekt 'door dingen aan te wijzen' (258), hij kan niet praten over abstracties 'want naar gedachten kon je niet wijzen' (258). Seamus daarentegen is de zanger, schoolmeester en boekhandelaar van het eiland, de man die als geen ander de taal kan hanteren. Hij zegt tegen Phil: 'Je zou Ino moeten heten Phil, vanwege je armen en je enkels' (238), en vertelt haar het verhaal van Ino uit de Odysseia. ${ }^{21}$ Ino wordt vergeleken met een meeuw, waarop Phil vraagt: 'Wat voor meeuw? Een mantelmeeuw?' 'Ze was geen meeuw. Ze werd er alleen mee vergeleken. Een metafoor - je weet toch wel wat dat is?' (238).

Een metafoor draagt in letterlijke zin betekenis van het ene op het andere object, het is een transportmiddel. Wat is het beste vehikel voor vervoering? Michaels zwijgzaamheid of Seamus' metaforen? Phil wil zich niet laten vervoeren of meeslepen door metaforen. Ze kiest voor Michael omdat hij haar de schoonheid van het zwijgen heeft laten zien: 'Als je meer zei dan nodig, verbrak je de betovering' (274). Het gaat zelfs verder dan dat. Metaforisch denken - iets aanzien voor iets anders - is een (dodelijke) vergissing.

Als Seamus Phil laat merken dat hij alsnog verliefd op haar is geworden raakt ze in dubio. Ze probeert zich voor te houden dat het 'geen verraad' is als ze nu weer voor Seamus zou kiezen (267), maar dan ziet ze hun hond aankomen met iets wits in zijn bek dat ze aanziet voor een dode meeuw of een schapenschedel. De meeuw verwijst natuurlijk naar Ino, waar Seamus haar mee vergeleek, de schapenschedel naar het schrikbeeld van de schapen die met gebonden poten van de klif storten. De hond blijkt een lekke voetbal in zijn bek te hebben, waarop ze concludeert dat ze het allemaal verkeerd ziet en Michael trouw moet blijven: '[ze] wist hoe het voelde als je een verkeerde keuze maakte, dan zag je overal dooie meeuwen en schapenschedels' (270).

Phil dacht een gelijkenis te zien waar die niet was. Zo'n zelfde vergissing is de oorzaak van de dramatische afloop van Spookliefde. Net zoals Ino haar sluier geeft aan Odysseus, geeft Phil haar omslagdoek aan Michael, tot twee keer toe: als ze na het eerste feest naar huis lopen en zij in haar broek plast van angst; en als ze na het tweede feest in haar kamer zijn en hij naar buiten moet om te plassen. Anders dan in de mythe redt de omslagdoek niet zijn leven, integendeel. Michael wordt neergeschoten door Seamus omdat die hem, met de doek om zijn middel, aanziet voor Phil.

\footnotetext{
${ }^{21}$ Ino 'met de sierlijke enkels' werd als godin vereerd maar was een mens geweest. De sluier die ze aan Odysseus geeft is 'onvergankelijk en beschermt tegen alles', als hij die om zijn middel wikkelt verdrinkt hij niet. '[Z]e overhandigde hem de sluier, daarna dook ze de woeste zee weer in als een zeemeeuw' (Homeros 1995, 94).
} 
Het is tijd voor een tussentijdse balans. Ik constateer dat in Spookliefde gotieke verhaalstructuren in stelling worden gebracht, die vervolgens in de kiem worden gesmoord. De roman presenteert een anachronistische spanning tussen een moderne heldin en haar traditionele omgeving. Die spanning gaat over de mogelijkheid van seksueel initiatief door vrouwen. De doelgerichtheid die het begrip seksuele autonomie in zich draagt verhoudt zich moeizaam met de overgave die noodzakelijk is voor seksualiteit, en vrouwelijke lust staat in een spanningsvolle verhouding tot religieuze verlangens. Het conflict komt in eerste instantie niet tot uitbarsting maar wordt geneutraliseerd doordat de heldin zich laat vervoeren haar archaïsche omgeving. Net zoals de tegenstelling tussen heldin en omgeving wordt geharmoniseerd, zo wordt ook de potentiële dreiging van het bovennatuurlijke geneutraliseerd. In plaats van gotiek en angstaanjagend krijgt het bovennatuurlijke een aantrekkelijke kant. Het Ierse eiland - katholiek en perifeer - vormt geen bron van gotieke dreiging maar van empowerment. Dat heeft consequenties voor de stelling van Baldick en Mighall dat de gotieke roman moderne waarden bevestigt via een anachronistisch conflict. Wat in Spookliefde resteert aan gotieke effecten is niet het resultaat van anachronismen, maar van een ander mechanisme: herhaling/verdubbeling. Tot besluit van dit hoofdstuk kijk ik nog eens goed naar de eigenschappen van anachronismen, en zet ik die af tegen het mechanisme van de herhaling.

\section{DE KRACHT VAN DE HERHALING}

Baldick en Mighall stellen dat de gotieke roman moderne waarden eerder bevestigt dan ondermijnt, via anachronismen. Hoe werken anachronismen precies? Het prefix 'ana-' betekent weer, tegen of terug, en dat impliceert een richting: het anachronisme beweegt zich tegen de richting van de tijd in (Phil had het gevoel dat haar ouders 'de verkeerde kant op' gemigreerd waren). Het concept anachronisme heeft een normatief aspect; het impliceert een correct verloop van de tijd. Dingen of personen zijn misplaatst als ze een anachronisme zijn, ze zijn in de 'verkeerde' tijd beland, terwijl ze natuurlijk in de 'goede' tijd moeten zijn. Een anachronisme maakt je bewust van zowel de historiciteit van het misplaatste object als de omgeving waarin het is geplaatst, en dat is precies het punt dat Baldick en Mighall willen maken: een anachronisme doet je de geschiedenis zien. Maar het is wel een specifieke soort geschiedenis. Het is noodzakelijk dat er een breuk wordt ervaren tussen heden en verleden, want anders kan het anachronisme niet bestaan. Het anachronisme maakt met andere woorden deel uit van het moderne historische besef; het heeft alleen betekenis vanuit een ontwik- 
kelingsperspectief op de geschiedenis. ${ }^{22}$ Baldick en Mighall zien in de gotieke roman deze sterke notie van ontwikkeling (modernisering, vooruitgang) terug. De geschiedenis volgt in die normatieve opvatting, ook wel 'a whiggish view on history' genaamd, een pad van onvermijdelijke vooruitgang en beoordeelt het verleden in het licht van het heden. ${ }^{23}$

In de oude gotieke romans die Baldick en Mighall bespreken, bevestigen de anachronismen moderne waarden, en daarmee ook het normatieve, lineaire concept van geschiedenis. In Spookliefde gebeurt iets anders. Spookliefde ondermijnt moderne waarden door het anachronisme te ondermijnen. De moderne waarden die ter discussie worden gesteld zijn - het idee van modernisering als secularisering; en de vanzelfsprekendheid van vrouwelijk seksueel verlangen.

Het anachronistische conflict wordt ondermijnd, zo stelde ik, doordat het zich verplaatst naar binnen. Verder is er een botsing van verschillende tijdsopvattingen. In Spookliefde conflicteert de lineaire tijd met een circulaire tijdsopvatting. De tijdsopvatting op het eiland laat zich niet beschrijven in termen van ontwikkeling. Er wordt geen breuk of zelfs maar een onderscheid gevoeld tussen heden en verleden, zoals Phil ervaart als ze haar vader een verhaal hoort vertellen. Het verhaal van vooruitgang, migratie en de American dream - het verhaal met een duidelijke richting, waarmee Phil op het eiland arriveert - , komt in botsing met de cyclische tijd van het eiland, waarin wederkeer het belangrijkste principe is en richting ontbreekt. Op het eiland bepaalt de kringloop van de seizoenen de hoogtijdagen: het feest waar Phil naartoe gaat is niet voor niets een oogstfeest. Phil wordt beïnvloed door de eiland-tijd; een concreet teken daarvan is dat ze ophoudt een horloge te dragen. Ze kan dit symbool van de chronologische tijd niet meer verdragen, omdat ze haar pols verbrand heeft. Dit 'verliezen van de tijd' herhaalt zich op het niveau van de raamvertelling. Het meisje is zo geboeid door Phils verhaal dat ze de hoorn van de vertrekkende avondboot verwart met die van de binnenkomende ochtendboot: 'Maar ik had alle besef van tijd verloren: de ochtendboot was allang aangekomen, deze boot stond op het punt te vertrekken.' (229). Als de tijd uit het oog verloren wordt, is ook de richting niet meer vast te stellen.

Spookliefde zit op allerlei niveaus vol met herhalingen en verdubbelingen. Deze herhalingen beschouw ik als 'tegenkrachten' tegen het vooruitgangsdenken die het verhaal zelf mobiliseert. Een keten van verdubbelingen is onderdeel

\footnotetext{
${ }^{22}$ Hoewel anachronistische verschijnselen ook in een cyclische tijdsopvatting wel voorstelbaar zijn (een kastanje in de lente, vorst in de zomer) wordt het anachronismebegrip doorgaans verbonden met het ontstaan van het moderne historische besef, zie Lowenthal (1985) en Blaas (1988). Zie ook hoofdstuk 1 , noot 26 .

${ }^{23}$ Zie hoofdstuk 1, noot 27.
} 
van de literaire vormgeving van het verhaal. Sommige herhalingen heb ik in het voorgaande al genoemd, maar ik zet er nog een aantal op een rijtje. Het eiland waar Spookliefde zich afspeelt is zelf al verdubbeld: het is 'een eiland bij een eiland' (225), en een andere opvallende verdubbeling is natuurlijk de tweeling, Seamus en Michael. Phils verlangen verdubbelt zich als ze ontdekt dat er twee broers zijn. Vijfentwintig jaar na het drama is Seamus zelfs zijn eigen dubbelganger geworden. Het meisje vraagt zich af of Phil ooit met de dichter uit haar verhaal is getrouwd, 'of was zijn plaats ingenomen door de oude, blonde man wiens wang ze gestreeld had? De man van wie gezegd werd dat hij een moord gepleegd had' (230). Zij weet op dat moment nog niet dat de oude blonde man dezelfde is als de dichter. De middelbare Phil steekt altijd twee kaarsen op: een voor de dode Michael en een voor de Seamus van vroeger, die ook dood is.

De meest in het oog springende herhaling is het verhaal dat zichzelf herhaalt. Spookliefde is een raamvertelling, een verhaal in een verhaal. Zoals vaak het geval is bij een dergelijke constructie lijken de twee verhalen op elkaar. Het verhaal over Phil, Seamus en Michael vormt een mise en abyme van het verhaal over het meisje en Ian. De gelijkenis tussen de twee verhalen suggereert dat de geschiedenis zich kan herhalen: wat Phil is overkomen zou het meisje ook kunnen gebeuren. Het verhaal dat zich herhaalt toont tegelijkertijd dat herhalingen niet alleen maar cyclisch zijn: ze kunnen de paradox in zich verenigen van wederkeer en verandering. ${ }^{24}$ Elke nieuwe generatie moet zich opnieuw tot dit verhaal verhouden.

Dat zorgt ervoor dat het verhaal per generatie een beetje kan veranderen, ook al blijft het hetzelfde. De vertelsituatie zorgt voor vermenging van de verhalen. In de raamvertelling, met de geschiedenis van het meisje en haar vriendje Ian, is het meisje de ik-verteller en focalisator. In de ingebedde geschiedenis over Phil staat het meisje de focalisatie af aan Phil, maar ze blijft wel de verteller. Een citaat kan dit verduidelijken: 'Ze [= Phil, AA] vertelde gedetailleerd, over het café waar ze had zitten wachten tot de boot vertrok: dat de ramen beslagen waren en dat er een kleffe geur hing van soep en natte jassen.' (217). Maar op dit punt gaan de verhalen door elkaar lopen, want de tekst vervolgt: 'Of is het mijn herinnering aan soep en natte jassen? Haar verhaal heeft zich

\footnotetext{
${ }^{24}$ Zie voor voorbeelden in de postmoderne roman: Vervaeck 2004 [1999], p. 157-161. Het meest basale voorbeeld van een herhaling die gelijkenis en verschil, wederkeer en ontwikkeling verenigt, is Frank Kermodes beroemde voorbeeld van de tikkende klok. Ik citeer Jonathan Culler over dit voorbeeld: 'when we say a ticking clock goes tick-tock, we give the noise a fictional structure, differentiating between two physically identical sounds, to make tick a beginning and tock an end: "The clock's tick-tock I take to be a model of what we call a plot, an organization that humanizes time by giving it form"' (Culler 1997, 84).
} 
vermengd met mijn herinnering aan O'Connor's, en mijn eerste overtocht, en mijn eerste keer eiland.' (217). In narratologische termen vervaagt het onderscheid tussen homodiëgetische en heterodiëgetische verteller, oftewel de betrokkenheid van de verteller bij het vertelde. Die wordt onduidelijk: heeft het meisje dit nu wel of niet meegemaakt? En die onduidelijkheid zal zich voortzetten als het verhaal opnieuw verteld wordt, zo stelt het meisje: 'Zoals het zich in het hoofd van degene aan wie ik het doorvertel weer zal mengen met herinneringen aan een ander café en een andere overtocht' (217).

De omstandigheden kunnen dus een beetje anders worden verteld - waarbij niet meer valt uit te maken bij welke versie die precies hoorden -, maar de posities worden herhaald. Het meisje, bevindt zich in dezelfde positie als Phil ten tijde van haar aankomst op het eiland - voor het eerst verliefd, onzeker over de afloop - en wij als lezers worden gepositioneerd als luisteraars naar de ikverteller, net zoals zij naar Phil luisterde. Als we dit spannende verhaal lezen zouden ook wij het besef van tijd kunnen verliezen, net zo geboeid door het verhaal als zij voor ons was. Een ander voorbeeld van de identieke posities waarin het verhaal de verschillende luisteraars manoeuvreert: Phil ontdekt pas na een tijdje dat er twee mannen zijn in plaats van één. Doordat Phil de focalisator is in het ingebedde verhaal, heeft haar luisteraar (het meisje) dezelfde ervaring, en op haar beurt weer de lezer. De verrassing herhaalt zich.

Spookliefde geeft zo via de vorm van de raamvertelling het idee van eindeloze herhaling gestalte. De geschiedenis kent geen vooruitgang, maar zal zich herhalen, in hetzelfde verhaal zullen steeds nieuwe personages hun plek innemen. Ian zit aan de bar op de plek van Seamus, het meisje kan of zal de plaats innemen van Phil, zoals Phil Seamus' plaats heeft ingenomen in de boekhandel. Seamus heeft door nooit meer te spreken de plaats van Michael ingenomen. De lezer kan op haar beurt de plaats van het meisje innemen, enzovoort.

Die narratieve vorm suggereert niet alleen oneindigheid, maar verhult ook de oorsprong van het verhaal. Het is niet alleen een verhaal zonder einde, maar ook zonder begin, zo lijkt het. Als het meisje voor het eerst in het plaatselijke café hoort over de moord die is gepleegd door de blonde, zwijgzame man op Ians barkruk, denkt ze: 'Het zou wel net zo'n legende zijn als over die rots die naar een gemartelde bisschop was vernoemd. Iedereen kende het verhaal, maar niemand wist of het echt gebeurd was' (213). In vijfentwintig jaar is het verhaal van Phil, Seamus en Michael een legende geworden, losgezongen van zijn historische wortels. De ingebedde vertelling in Spookliefde, het verhaal in het hart van de roman, dient om die historische wortels (weer) bloot te leggen. Phils verhaal moet de authenticiteit van de legende bevestigen. Dan blijkt dat de 
keten van plaatsvervangers niet oneindig is, maar een duidelijke oorsprong heeft: het begon bij Michael, die stierf in Phils plaats.

Michael is de voornaamste bron van gotieke effecten in Spookliefde: hij belichaamt enerzijds de gotieke dreiging van (seksueel) geweld, en anderzijds het contact met het bovennatuurlijke. Hij is de dode man die terugkeert, niet als spook, maar in de verhalen over ware liefde die verteld zullen worden aan toekomstige generaties jonge vrouwen. De eerste keer dat hij herkenbaar zijn opwachting maakt in het verhaal - als Phil ontdekt dat Seamus een tweelingbroer heeft - zegt Phil tegen het meisje dat het verhaal daar had kunnen eindigen: 'Hier zou dit verhaal kunnen eindigen. Ik geloof dat de vrouw van de boekwinkel, de vrouw die ik Phil noem omdat ik indertijd heb beloofd haar naam nooit te onthullen, het hier liever bij had gelaten' (243). Phil vertelt pas verder als ze gecheckt heeft of het meisje oud genoeg is om de rest van het verhaal, de oorsprong van de legende te horen. Het verhaal gaat verder, omdat Michael dood is. Zijn dood verzekert zijn voortbestaan in het verhaal, en andersom garandeert zijn dood dat het verhaal zal voortleven.

Het verhaal loopt vooruit op zijn eigen voortbestaan, op de eindeloze herhaling van zichzelf. Phil zegt aan het eind tegen het meisje: 'Als je dit doorvertelt...'. Dit kan gelezen worden als een aansporing. Het meisje zegt: 'O, maar dat doe ik niet, dat beloof ik', alsof ze een geheim heeft gehoord dat ze niet verder zal vertellen. Maar Phil staat er zowat op: 'O ja, dat doe je wel. Je vertelt het aan Ian [...] of aan iemand anders' (287). ${ }^{25}$ Het verhaal zal zich herhalen. Het meisje zegt aan het eind van het verhaal tegen Phil dat ze terug zal komen. 'Iedereen komt terug', antwoordt Phil. Net zoals zijzelf teruggekomen is na Michaels dood.

Een laatste vorm van herhaling is die tussen critici en tekst. ${ }^{26}$ De recensenten herhalen onwillekeurig een element uit de tekst. Ze stellen zich bijna allemaal de vraag waarom de roman 'Een Iers verhaal' heet, en verwachten op grond van die titel dat ze een saga-achtig verhaal te lezen krijgen; een verhaal uit

\footnotetext{
${ }^{25}$ Wat hier gebeurt is vergelijkbaar met het mechanisme dat J. Hillis Miller herkent in Wuthering Heights, in zijn beroemde studie Fiction and Repetition (1982). Hij stelt dat de situatie van de lezer is ingeschreven in de roman, in de situaties van de personages, die ook allemaal vertellers of lezers zijn: 'The lesson for the reader is to make him aware that he has by reading the novel incurred a responsibility like that of the other spectator-interpreters.' (Hillis Miller 1982, 70).

${ }^{26}$ Shoshana Felman beschrijft dit fenomeen in haar interpretatie van Henry James' The Turn of the Screw. De critici zijn geneigd om de posities te herhalen die worden aangeboden door de tekst zelf: 'they are found to repeat unwittingly - with a spectacular regularity - all the main lexical motifs of the text' (Felman 1982, 98). Zie ook hoofdstuk 2, noot 7. Over Spookliefde heeft weliswaar niet zo'n kritisch debat gewoed als over The Turn of the Screw, maar het principe is hetzelfde.
} 
de overlevering dus, van een twijfelachtige waarheid. Daarmee herhalen ze precies de verwachtingen van de ik-persoon uit de raamvertelling: ook het jonge meisje verwacht van Phil een legende te horen, in plaats van een waargebeurd verhaal. Maar net zoals Phils verhaal - binnen de fictionele wereld - een historische basis blijkt te hebben, zo kan 'Iers verhaal' als historisch waarschijnlijk worden geïnterpreteerd, zo heb ik laten zien.

Phils verhaal is een waarschuwing voor het meisje, en haar verhaal is op zijn beurt een waarschuwing voor de lezer. Phils ervaringen van controleverlies en haar mislukte vrijpogingen met Michael tonen de mismatch tussen verlangen en overgave. Verlangen laat zich niet manipuleren, moet de conclusie haast wel zijn. Of toch? Phil roept hogere machten aan om haar verlangen te laten beantwoorden: via het dagelijkse ritueel van de kaars en het gebed in de kapel. De kracht van het gebed is reden voor de oudere Phil om het jonge meisje te waarschuwen: 'Bid maar dat je gebed niet verhoord wordt. [...] Ja, wens dat je wens niet in vervulling gaat' (215).

Met dit gebed is iets vreemds aan de hand. Paradoxaal genoeg moet dit tweede gebed, deze 'wens dat je wens niet in vervulling gaat', wél verhoord worden om het eerste gebed níet in vervulling te laten gaan. Daarmee ontstaat een verdubbeling van wensen die de ene wens van de andere onderscheidt; identiek maar toch verschillend. De tweede wens (om niet verhoord te worden) wordt sterker verklaard dan de eerste wens (om beantwoorde liefde). Maar wat is nu precies de inzet van het tweede gebed? Moet het tweede gebed verlossing brengen van beantwoord seksueel verlangen? Of moet het verlossen van het verlangen naar beantwoorde liefde? Of houdt Phil een pleidooi om religieuze wensen en seksuele verlangens liever gescheiden te houden? Om de zaken uit elkaar te houden, verschillend te laten zijn en niet verdubbeld.

$\mathrm{Na}$ haar ontdekking dat er twee broers zijn in plaats van een verlangt Phil terug naar de tijd dat ze de broers als eenheid ervoer: 'Nu ze wist dat er twee broers waren zag ze alleen nog maar verschillen. Kleine, maar onmiskenbare verschillen. Hoe langer ze keek, des te heviger verlangde ze naar de tijd dat ze nog van niets wist.' (242) Die kennis kan niet ongedaan worden gemaakt. De enige manier waarop twee weer tot een teruggebracht kunnen worden is met geweld. Terwijl Phil op het punt staat aan zichzelf toe te geven dat Michael geen seksuele begeerte kent, ziet Seamus haar dansen met Michael, op de plek waar hij had willen staan: 'Misschien was het wel zijn schaduw die daar danste, had zijn schaduw zich losgemaakt van hemzelf en was een eigen leven gaan leiden.' (278) Die gedachte - de gedachte dat de dubbelganger niet langer dubbelganger is maar een eigenstandig wezen - maakt hem misselijk. Hij schiet naar hij denkt op Phil, om haar een lesje te leren, maar het blijkt zijn eigen 
broer. Een symbolische illustratie van die reductie van twee naar een is het rouwritueel waarbij spiegels in een huis bedekt worden na een sterfgeval. De spiegel in Phils kamer wordt bedekt met dezelfde gehaakte omslagdoek die Michael aanhad toen hij werd neergeschoten.

Spookliefde toont, door middel van al zijn herhalingen, wat toekomstige generaties jonge vrouwen zal achtervolgen: de angst om niet seksueel actief te worden, om niet de grote liefde te vinden. Maar wat hen zal achtervolgen is ook de twijfel aan hun eigen verlangen, zoals Phil haar verlangen naar seks begon te betwijfelen. Alle herhalingen en verdubbelingen relativeren de noties van lineariteit en vooruitgang. De analyse van de anachronismen in Spookliefde vestigt de aandacht op mogelijke connecties tussen een historische context - Ierland als betekenisvolle locatie - en de processen van modernisering; maar de verdubbelingen en herhalingen tonen de ambiguiteit van modernisering, en de twijfels van het moderne subject. Temidden van alle herhalingen valt op dat juist het nietherhaalbare in dit verhaal niet plaatsvindt: de eerste keer, het verlies van de maagdelijkheid: wat nooit eerder gebeurd is en wat per definitie niet herhaald kan worden.

Spookliefde laat zien dat de gotieke roman bij uitstek geschikt is om ambivalenties over aspecten van modernisering tot uitdrukking te brengen, zoals de aanname dat modernisering leidt tot secularisatie. Via gotieke verdubbelingen is Van der Meer in staat om een religieuze sensitiviteit in haar heldin, Phil, en in de verteller te mobiliseren. Een katholiek eiland vormt daarvoor een realistische setting. De vanzelfsprekendheid van vrouwelijk seksueel verlangen, een moderne verworvenheid, komt daarbij onder druk te staan. 



\title{
7
}

\section{'SEEING THINGS'. Slotbeschouwing}

\author{
Last night I had a dream \\ You were in it, I was in it with you \\ Everyone that I know \\ And everyone that you know was in my dream \\ I saw a vampire \\ I saw a ghost \\ Everybody scared me but you scared me the most \\ In the dream I had last night
}

Randy Newman, 'Last night I had a dream', Sail away, 1972

Wat doet het gotieke in Nederlandse literatuur aan het eind van de twintigste eeuw? Dat was de vraag waarmee dit boek begon, en ik heb die vraag op twee manieren opgevat. Ten eerste wilde ik nauwkeurig nagaan op welke manier het gotieke zich manifesteerde in een aantal Nederlandse romans uit de periode 1980-1995. Via de gedetailleerde analyse van individuele teksten verkende ik de mogelijkheden van een gotiek interpretatiekader. Deze vraag mondde uit in een exercitie in close reading, waarbij ik in elk hoofdstuk analyseerde hoe gotieke motieven literair effect sorteren in zes laattwintigste-eeuwse romans, van vijf auteurs.

Met die romananalyses wilde ik mijn tweede vraag beantwoorden: wat is het culturele werk dat deze romans via het gotieke verrichten? Mijn uitgangspunt daarbij was dat het gotieke een culturele strategie is om ambivalenties vorm te geven over aspecten van modernisering. Via het gotieke wordt de tegenstelling tussen heden en verleden vervat in termen van primitief en beschaafd, c.q. traditioneel versus modern. De dynamiek van vooruitgang en achterblijven, oftewel de dynamiek van de modernisering, is wezenlijk voor het gotieke. Het contrast 
tussen modern heden en archaïsch verleden krijgt keer op keer via het gotieke gestalte, en kan per periode een ander accent krijgen.

Voor mijn analyses koos ik romans die verschenen tussen 1981 en 1995. In de periode daarvoor, de jaren zestig en zeventig, maakte Nederland op vele terreinen een snelle modernisering door. Volgens historicus James Kennedy was de dominantie van de vooruitgangsretoriek daarbij opvallend. Doordat men vooruitgang onontkoombaar achtte, verliepen de emancipatieprocessen overwegend rimpelloos, aldus Kennedy. Onder andere daardoor kon Nederland al snel een icoon worden van seksuele bevrijding, vrouwenemancipatie en individualisering. Wat heeft het gotieke dan nog aan maatschappelijke spanningen te herwerken, zou men zich af kunnen vragen. Uit de analyses van mijn materiaal blijkt: meer dan genoeg.

Het algemene antwoord op mijn eerste vraag, naar de manifestaties van het gotieke en het effect daarvan in de onderzochte romans, laat zich enigszins voorspellen. In dit bescheiden corpus bleek dat op zeer uiteenlopende wijze uit het gotieke repertoire wordt geput. Dat hoeft niet te verbazen, aangezien het gotieke vele elementen en motieven in de aanbieding heeft. Het wordt gebruikt als etiket voor zeer uiteenlopende werken, die een lange periode en verschillende landen omspannen. De romans die in dit onderzoek centraal stonden honoreren die verscheidenheid van het gotieke repertoire.

We treffen typisch gotieke personages aan als de aristocratische schurk, de onschuldige heldin die op zoek is naar avontuur, en de madwoman. 'Echte' bovennatuurlijke wezens - monsters, zombies, vampiers, weerwolven dan wel spoken - blijken schaars. De spoken en vampiers verschijnen eerder als metaforen. De romans die in Nederland gesitueerd zijn creëren een gotieke atmosfeer door fysieke afzondering te ensceneren. De bibliotheek met zijn Kapel in Letter en Geest, de villa van Christine met het kistje in De vierde man, en de villa van de familie Van Hal met zijn geheime kamertje in Vriend van verdienste zijn zelf belangrijke 'spelers' in het verhaal. Ze vertegenwoordigen een andere orde, die de hoofdpersoon van de respectievelijke romans met zichzelf confronteert.

De toonzetting van de romans is heel verschillend: van expliciet ironisch en zelfreflexief in De vierde man en Perpetuum mobile tot excessief en daardoor soms hilarisch gotiek in Noorderzon; van mild verontrustend bij Van der Meer en onderkoelde paniek bij Kellendonk, tot abjecte horror bij Rosenboom. Voor de hand liggende bronnen van gotieke effecten laten de schrijvers links liggen: Kellendonks spook is niet unheimlich, de cassettebandjes van Topaas evenmin. Ik duid deze Nederlandse gotieke romans daarom aan als 'griezelig gewoon'. 
Het anachronisme, dat door Robert Mighall als typisch element in gotieke romans wordt beschouwd, komt in mijn selectie niet zoveel voor. Vriend van verdienste is de enige roman die wel duidelijk in het verleden gesitueerd is. Een historische afstand van twintig jaar blijkt daar voldoende voor het oproepen van de tegenstelling ouderwets-modern. Noorderzon en Spookliefde creëren anachronismen via een geografisch contrast, waarbij opvalt dat een eiland in de periferie van het Verenigd Koninkrijk - Schots (Noorderzon) dan wel Iers (Spookliefde) in de Nederlandse verbeelding kennelijk dé gotieke locatie bij uitstek vormt. Dorrestein en Van der Meer tonen daarmee hun schatplichtigheid aan de Britse en Ierse gothic.

Op grond van zes romananalyses kan en wil ik geen algemene uitspraken doen over het gotieke in Nederlandse literatuur. Wel wil ik constateren dat het gotieke leeft in Nederlandse literatuur, voor wie daar oog voor heeft - ik roep Brewsters uitspraak nog eens in herinnering: 'reading gothic makes us see things'. En daarmee kan ook de literatuurbeschouwing over het gotieke een bloeiend bestaan leiden. Met een gotiek interpretatiekader worden verbanden zichtbaar tussen auteurs die tot nu toe zelden met elkaar in verband zijn gebracht. Er worden verwantschappen zichtbaar tussen Reve en Kellendonk, en tussen Dorrestein en Van der Meer. Zowel Letter en Geest als De vierde man laten een poging zien om in de heteroseksuele orde mee te doen en een echte man te worden. Spookliefde lijkt de keurige herschrijving van Noorderzon: in beide romans belandt een vrouw alleen op een gotiek eiland. Ook tussen Perpetuum mobile en De vierde man zie ik overeenkomsten: de (semi-)autobiografische structuur wordt gecombineerd met de spottende toon van de verteller die afstand creëert.

Een gotiek interpretatiekader laat niet alleen nieuwe verbanden tussen $\mathrm{Ne}$ derlandse auteurs onderling zien. Het vormt bovendien een stimulans om Nederlandse literatuur in verband te brengen met buitenlandse, in dit geval vooral Engelstalige literatuur. Auteurs worden vaak geïsoleerd bestudeerd, of hooguit met een andere Nederlandse auteur vergeleken. Maar literatuur is geen louter nationaal gebeuren meer, voor zover het dat ooit geweest is. Een analyse van het gotieke biedt een nieuwe kijk op internationale invloeden, verwantschappen en tradities. De rijkdom aan gotieke motieven die ik bij mijn analyses aantrof laat de internationale oriëntatie van Nederlandse auteurs goed zien.

Wat betekenen deze constateringen over de verschijningen en literaire effecten van het gotieke voor de beantwoording van mijn tweede vraag, naar het culturele werk dat deze gotieke romans verrichten? Via het gotieke, zo veronderstelde ik, kunnen ambivalenties bij de verworvenheden van de snelle moderniserings- 
golf van de jaren zestig en zeventig worden verbeeld. Ik concentreerde mij bij mijn analyses op sekse en seksualiteit, terreinen waarop veel veranderde. Feministen streden onder andere voor gelijkheid van mannen en vrouwen, voor het zelfbeschikkingsrecht van vrouwen en tegen seksisme; de seksuele revolutie vestigde de aandacht op de individuele beleving van seks; de zichtbaarheid van homoseksualiteit groeide door het nieuwe actierepertoire van coming out. Definities van mannelijkheid en vrouwelijkheid veranderden ingrijpend. Die emancipatieprocessen blijken de nodige ambivalenties op te roepen. Het gotieke leidt in deze romans uiteindelijk niet tot een simpele bevestiging van moderne waarden, maar tot het plaatsen van vraagtekens daarbij.

Ik richtte mijn blik in eerste instantie op het terrein van de seksuele emancipatie, waartoe ik de nieuwe definities van mannelijkheid en vrouwelijkheid reken, alsook de seksuele gelijkwaardigheid van mannen en vrouwen, de seksuele autonomie van vrouwen en de homo-emancipatie. Alle romans blijken zich daar op de een of andere wijze mee te verstaan. In elk van de romans die ik analyseerde worden via het gotieke ambivalenties vormgegeven over nieuwe man-vrouwverhoudingen en ideeën over seksualiteit, die in de jaren zestig en zeventig ingang vonden. In De vierde man wordt de draak gestoken met moderne seks waarbij gelijkwaardigheid van beide partners het devies is. Tegelijkertijd wordt de seksuele autonomie van vrouwen als bedreigend voorgesteld. Het gotieke markeert een machtstrijd tussen de seksen, die consequenties heeft voor definities van mannelijkheid: wat betekent het (nog) om een echte man te zijn? Die vraag heeft ook implicaties voor de auteur Reve, in wiens werk een nauwe band tussen seks en schrijverschap bestaat. De vierde man ontmaskert de natuurlijkheid van het romantische heteroplot, maar biedt geen geslaagde poging om een alternatief homoplot te formuleren. Dit ondanks het feit dat de schrijver Reve vanaf het begin van de jaren zestig als geen ander expliciete beschrijvingen van homoseksualiteit mogelijk had gemaakt.

Ook in Noorderzon en Spookliefde wordt via het gotieke vrouwelijke seksuele autonomie aan de orde gesteld. De vrijgevochten Topaas en de jonge Phil worden op hun respectievelijke eiland geconfronteerd met hun kwetsbaarheid als vrouw alleen. Beide romans laten zich lezen als een variatie op het female gothic plot, maar Dorrestein en Van der Meer doen er verschillende dingen mee. In Noorderzon wordt het romantische plot met geweld bestreden; in Spookliefde is het romantische ideaal intact. Daar is de vraag hoe overgave zich verhoudt tot moderne seksuele autonomie; de frictie tussen beide wordt via het gotieke zichtbaar gemaakt.

Letter en geest laat zich lezen als een kanttekening bij de nieuwe coming out strategie van de homobeweging van de jaren zeventig. De vervaging van grenzen 
tussen privé en openbaar en de noodzaak om een seksuele identiteit te claimen veroorzaken paniek bij Mandaat. Het gotieke personage Van Uffel vertegenwoordigt een oudere homoseksuele identiteit, die niet op basis van coming out, maar op basis van een gedeeld geheim gedefinieerd wordt.

In Vriend van verdienste zijn definities van mannelijkheid en klasse met elkaar verweven: op het moment dat Theo zijn intrek neemt in de villa en daarmee klassengrenzen overschrijdt, komt mannelijkheid in het nauw. De machtstrijd van de jongens leidt tot verwarring tussen rivaliteit en homoseksueel verlangen, maar zo'n verlangen is, anders dan voor omstanders en lezers, voor de betrokkenen (Theo en Pieter) niet herkenbaar of benoembaar. De roman presenteert zo een idee van seksuele onschuld dat archaïsch aandoet.

Perpetuum mobile biedt wat mij betreft een verrassing. Renate in Perpetuum mobile schetst de romantische ideologie die vrouwen nog altijd beknot, onder verwijzing naar de gothic novel. Hoewel de roman een duidelijk feministische inzet heeft, manifesteert het gotieke zich niet als een spanning tussen de seksen. Er wordt een tegenstelling tussen collectiviteit en individualiteit vormgegeven via de metafoor van vampiristisch zusterschap.

Deze ambivalenties bij de verworvenheden van emancipatie op het gebied van sekse en seksualiteit hebben gevolgen voor het romantische plot. In de klassieke gotieke roman is romance niet eenduidig - voor vrouwen betekent het zowel onderwerping aan de wetten van de huwelijksmarkt, als een vrijbrief voor het beleven van passies die anders ondenkbaar zijn. ${ }^{1}$ In deze laattwintigsteeeuwse romans is een romantisch plot niet zozeer meerduidig als wel een onmogelijkheid, of dat nu een homo- of heteroseksueel plot is. Brems (2006) stelt dat literatuur in de jaren zestig soms een voortrekkersrol had op het gebied van seksualiteit en dat juist seksuele bevrijding gold als een typisch teken van moderniteit. De romans die ik in dit boek analyseerde lijken niet zo'n voortrekkersrol te ambiëren. Ze maken eerder de balans op van de verschuivingen die er op het gebied van sekse en seksualiteit hebben plaatsgevonden.

De ambivalenties over moderne verworvenheden hebben twee verschillende aangrijpingspunten. Het eerste aangrijpingspunt is de dominantie van de nieuwe verhoudingen: hoe stevig zijn de nieuwe waarden verankerd? is het oude werkelijk voorbij? Zo ontaardt (schijnbare) klassenmobiliteit in Vriend van verdienste in een strijd op leven en dood. Topaas in Noorderzon moet net als Renate in Perpetuum mobile nog steeds haar onafhankelijkheid bevechten. Het tweede aangrijpingspunt is ambivalentie over de waarde van die nieuwe verhoudingen: is het nieuwe beter dan het oude? Mandaat in Letter en Geest, en Phil in

\footnotetext{
${ }^{1}$ Zie Botting (2009), 153 e.v. .
} 
Spookliefde lijken dat te betwijfelen. De twee niveaus zijn niet altijd strikt te scheiden: in De vierde man test Gerard test de dominantie van de nieuwe verhoudingen met zijn parodie, ondertussen prefereert hij 'ouderwetse' mannelijkheid.

Door alle romans samen te lezen vallen weer nieuwe dingen op. Uit mijn interpretaties komen verrassende overeenkomsten op twee terreinen naar voren: alle romans verhouden zich op de een of andere manier tot het katholicisme, en ze snijden allemaal het thema aan van het onvermogen om een eigen leven te leiden.

Wat betreft de katholieke elementen valt op dat in elk van de hier besproken romans- al dan niet geperverteerde - katholieke rituelen, heiligen en/of personages een rol spelen. Het gotieke personage Van Uffel in Letter en Geest is tot priester gewijd en laat zich in soutane door jonge jongens bevredigen; daarnaast is er het ideaal van de 'gemeenschap van heiligen', waarvan Mandaat beseft dat hij er nooit bij zal horen. In Noorderzon wil Topaas via de biecht aan een dronken abt op het gotieke eiland van haar Boze Oog verlost worden. Theo probeert in Vriend van verdienste via offerandes op een zelfgewijd altaar - het theekastje - zuiverheid te bereiken. Gerard tracht in De vierde man via een al even corrupte katholieke formule - door Haar tot Hem - zijn ideale liefde te bereiken. De heilige Lucia, die zowel in Noorderzon als in Perpetuum mobile wordt aangeroepen, zet de wens van respectievelijk Topaas en Renate om niet begeerd te worden kracht bij. In Spookliefde tenslotte probeert Phil haar romantische verlangen te laten vervullen door een kaars op te steken in een kerk.

De corrupte clerus, die is gaan behoren tot de standaardentourage van de gotieke roman, is hier losgezongen van zijn Brits-nationalistische context. Britse gotieke romans van de eerste generatie staan bekend om hun felle anti-katholieke sentimenten. Katholieke landen als Italië en Spanje vormen de achtergrond waartegen de gruwelen van de Inquisitie breed kunnen worden uitgemeten, dit ter versterking van een moderne, Britse protestantse ideologie. ${ }^{2}$ Katholicisme fungeert in die gothic novels met andere woorden als 'de ander' van de Britse identiteit. In de twintigste-eeuwse Nederlandse gotieke roman lijken die anti-katholieke sentimenten afwezig. In deze Nederlandse romans staat het katholicisme niet in dienst van het versterken van een nationale identiteit. Het gotieke blijkt een vehikel om katholiek getoonzette verlangens naar verlossing en vervulling te verwoorden. De conclusie lijkt gerechtvaardigd dat secularisering in deze gotieke romans niet het vanzelfsprekende eindpunt vormt

\footnotetext{
${ }^{2}$ Zie Sage (1988) en Miles (2007).
} 
van de moderniteit. Weliswaar hebben de katholieke rituelen in de meeste gevallen een parodiërend karakter, maar het verlangen lijkt er niet minder oprecht om. Spookliefde is een uitzondering. Daar mobiliseert Van der Meer een religieuze sensitiviteit in haar moderne heldin, Phil en in de verteller, die niet wordt geridiculiseerd. Een afgelegen, katholiek eiland vormt daarvoor de realistische setting.

Een tweede opvallende overeenkomst tussen hier geanalyseerde romans zie ik op het terrein van wat ik zou omschrijven als het ideaal van zelfverwerkelijking. Stuk voor stuk thematiseren de romans het onvermogen van de hoofdpersoon om zichzelf te verwezenlijken, om hun eigen leven te leiden. Het is zonder meer opmerkelijk dat in elk van de romans die ik in dit boek analyseerde, rolwisselingen, dubbelgangers en plaatsvervangers voorkomen, oude bekenden in het gotieke repertoire. In Vriend van verdienste wil Theo Pieter worden (via de spiegel 'ziet' hij zichzelf als Pieter) en zij wisselen uiteindelijk van plaats. Theo krijgt Pieters overhemd en mag op zijn paspoort naar het buitenland; de gevolgen voor Pieter zijn fataal. Mandaat in Letter en Geest wordt al geboren als plaatsvervanger van iemand anders: hij komt in plaats van een gestorven broertje. In de bibliotheek neemt hij de plaats in van de heer Brugman. Ik heb betoogd dat zijn onvermogen om een eigen identiteit te claimen en een eigen plaats in te nemen in de gemeenschap een bron van paniek is die op gotieke wijze wordt vormgegeven. In Noorderzon denkt Topaas dat zij het leven van de verongelukte Lin moet afmaken. Gaandeweg neemt ze de positie van de doofstomme Wants in en gaat ze ook uiterlijk op hem lijken. Justine neemt op haar beurt Topaas' plek naast Julius in. De keten van stand-ins is een bron van het gotieke. Ook Renate in Perpetuum Mobile heeft last van dubbelgangers. $\mathrm{Ze}$ is ternauwernood in staat haar eigen stem (terug) te vinden: de vampiristische band met haar (on)dode zusje verhindert haar haar werk als het hare te beschouwen, en ze heeft moeite haar eigen feministische motieven te onderscheiden van die van Godelieve, haar 'monster van Frankenstein'. Terwijl het gotieke monster doorgaans verschil markeert, is dat hier anders: het is too close for comfort, er is teveel gelijkenis.

Gerard in De vierde man weet evenmin wie hij echt is: hij speelt een ander, een heteroseksuele man, en die verwarring wordt via het gotieke verbeeld. Zijn geslaagde hetero-imitatie doet hem vrezen dat hij de plaats heeft ingenomen van drie dode echtgenoten, en dat zijn lot daarmee bezegeld is. Ook in Spookliefde nemen de personages elkaars plaats in, met fatale gevolgen. Phils keuze voor Michael in plaats van zijn tweelingbroer Seamus leidt uiteindelijk tot Michaels dood. Het jonge meisje dat Phils verhaal aanhoort lijkt ook haar plaats in te nemen: de geschiedenis herhaalt zich. 
Met mijn focus op de herwerking van moderniseringsprocessen interpreteer ik deze stoet van dubbelgangers en plaatsvervangers in termen van de moderne opdracht bij uitstek: om een authentiek individu te zijn. Volgens de filosoof Charles Taylor (1991) wordt aan moderne individuen sinds Rousseau een moreel appèl gedaan om authentiek te zijn, dat wil zeggen, om zichzelf te zijn, om zichzelf te verwezenlijken. Dit werd in 1975 overigens prachtig bezongen door de seismografen van de Nederlandse tijdgeest, Kees van Kooten en Wim de Bie, in hun lied 'Zoek jezelf. ${ }^{3}$ Het moderne individualisme behelst de vrijheid om zichzelf te zijn, een verworvenheid die mensen recht geeft op hun eigen overtuigingen en tot op zekere hoogte in staat stelt hun leven uit te stippelen. Maar dat individualisme is niet vrijblijvend volgens Taylor. Authenticiteit is niet zomaar een ideaal, het is een opdracht, en die is niet eenvoudig. Taylor spreekt van een 'ethics of authenticity': de opdracht om jezelf te worden heeft een moreel aspect; en daarmee ook een sociale dimensie: onze authentieke identiteit heeft een 'need for recognition'. Niet elke zelfdefinitie is herkenbaar of significant; die vindt altijd plaats ten overstaan van anderen, tegen een horizon van keuzes die als significant erkend worden. ${ }^{4}$

Taylor werkt niet uit wat de gevolgen zijn van veranderende horizonten. Wie je kunt zijn of worden is contextspecifiek. De historische strijd over betekenissen van sekse en seksualiteit heeft gevolgen voor de manier waarop individuen zichzelf kunnen articuleren. Wie zichzelf als 'modern' wil definiëren dient na de 'jaren zestig' andere keuzes te maken, andere zelfdefinities te hanteren dan daarvoor, juist op een terrein als seksualiteit, dat als bepalend voor identiteit wordt beschouwd.

De hier geanalyseerde romans stellen identiteit aan de orde, tegen een achtergrond van veranderde verhoudingen op allerlei terreinen. De hoofdpersonen dreigen allemaal te falen in de morele opdracht om zichzelf te zijn: ze willen iemand anders zijn, ze voelen zich iemand anders of in ieder geval niet zichzelf. Ze voelen de moderne ethic of authenticity op hun schouders drukken maar weten zich geen houding te geven. Wat betekent het om een man te zijn (Reve, Rosenboom), een vrijgezel (Kellendonk), een homoseksueel (Reve en Kellendonk), een vrouw (Van der Meer), een feminist (Dorrestein), een vriend (Ro-

\footnotetext{
${ }^{3}$ Het eerste couplet luidt: 'Allemaal op weg naar niets, doen we zus of zomaar iets / Soms net echt, maar meestal kitsch, want wie speelt er nog zichzelf / Weet je nog wanneer dat was, toen je nog geen ander was / Niet in harnas achter glas, maar je eigenlijke zelf / Zoek jezelf broeders (zusters), vind jezelf, wees en blijf alleen jezelf.

${ }^{4}$ Een voorbeeld van een niet-significante zelfdefinitie volgens Taylor: 'I may be the only person with exactly 3,732 hairs on my head, or be exactly the same height as some tree on the Siberian plain, but so what?' (Taylor 1991, 36).
} 
senboom)? In de nieuwe maatschappelijke verhoudingen is dat allerminst duidelijk.

Op grond van deze romananalyses kan het bestaande beeld van de Nederlandse roman in de jaren tachtig bijgesteld worden. Tot nu toe is dat beeld vaak gebaseerd op de indelingen die betrokkenen - auteurs, critici, letterkundigen - in de jaren tachtig zelf maakten. In de diverse polemieken over de plaats van literatuur die zich begin jaren tachtig afspeelden, werd een drie-, soms vierdeling gehanteerd tussen Revisor-proza (o.a. Kellendonk, De Jong), subjectivistische anekdotiek (o.a. Van Keulen en 't Hart), 'ander' proza (Vogelaar, Van Marissing), en soms feministisch proza. Brems (2006) relativeert die indeling in zijn recente literatuurgeschiedenis - nadat hij die overigens eerst herhaald heeft - en noemt die ontoereikend. Wie kijkt vanuit het perspectief van vertelplezier, of postmodernisme, of intertekstualiteit, vindt verwantschappen tussen auteurs die in de oorspronkelijke indeling als opponenten werden voorgesteld, aldus Brems.

Ook een gotiek interpretatiekader heeft dat effect. In dit boek heb ik laten zien hoe het perspectief van het gotieke zeer uiteenlopende romans en auteurs met elkaar verbindt. Literatuur uit die periode is wel beschuldigd van gebrek aan engagement (Goedkoop 2004). Het is maar net hoe je engagement definieert. Gelezen door de lens van het gotieke blijken de hier gepresenteerde romans niet onmaatschappelijk zijn, maar zeer betrokken bij de fricties over nieuwe definities van sekse, seksualiteit, sociale mobiliteit, vriendschap en religiositeit.

$\mathrm{Nu}$ die lens is geslepen, doemen nieuwe vergezichten op van studies naar het gotieke in de Nederlandse literatuur. De mogelijkheden zijn legio. Wie geïnteresseerd is in gothic mansions, kan beginnen met Kees Ouwens' De strategie (1968), In Babylon (1997) van Marcel Möring en Het Huis M. (1993) van Atte Jongstra. Wie Frankenstein-variaties prefereert, kiest Hémans duik (1994) van Arie Storm of De engelenmaker (2005) van Stefan Brijs; vampiers zijn te vinden in Gekkenschemer (1974) en Stierenoffer (1975) van Louis Ferron. Er zijn romans van schrijvers wier hele oeuvre door het gotieke lijkt geïnspireerd (Manon Uphoff), of die een enkel uitstapje maken (Anton Koolhaas, Een kind in de toren 1978); van oudere schrijvers als Hugo Claus (van wie ooit de uitspraak werd opgetekend 'Flemish Gothic, dat is mijn genre' (Piryns 1999)), en van jongeren als Thomas van Aalten (Sluit deuren en ramen (2003)) en Saskia de Coster (Jeuk (2004)). De invalshoek van vertalingen zou interessant zijn: daarin leggen schrijvers als Simon Vestdijk, Anton Haakman, en natuurlijk Kellendonk, een belangstelling voor het gotieke aan de dag die vaak ook in hun ro- 
mans blijkt. ${ }^{5}$ Ook het gotieke korte verhaal biedt een goed uitgangspunt voor nader onderzoek. Behalve de twee bundels griezelverhalen die Robert-Henk Zuidinga $(1984,1986)$ samenstelde zijn er ook gotieke verhalen van auteurs als F. Bordewijk, Jan Wolkers, Jacques Hamelink, Belcampo, Karin Spaink en H.C. ten Berge. Gothic van vrouwen, van Vlamingen, in de Indische literatuur, in jeugdboeken, ja zelfs in non-fictie: het behoort allemaal tot de mogelijkheden. ${ }^{6}$

Een gotiek interpretatiekader is een manier om auteurs samen te lezen die anders niet snel met elkaar in verband worden gebracht; en één die het mogelijk maakt om een verbinding te leggen tussen literatuur en de historische context waarin zij functioneert. Een ander voordeel is dat een gotiek interpretatiekader een stimulans vormt om Nederlandse literatuur in verband te brengen met buitenlandse literatuur. Ten slotte is het gotieke lezen een pleidooi voor de interpretatie. Het is een manier van kijken die nieuwe betekenissen genereert. Die betekenissen zijn er niet zomaar. Pas door langdurig op te trekken met de romans uit dit boek, door te lezen, te herlezen en nog eens te herlezen, kon ik zien wat ik zag.

\footnotetext{
${ }^{5}$ Vestdijk vertaalde Edgar Allan Poe en Stevensons Jekyll and Hyde. Zelf schreef hij Het wezen van de angst (1968) (zijn proefschrift) en romans als De zwarte ruiter (1940) en Het spook en de schaduw (1965). Haakman maakte vertalingen van Mario Praz' klassieker The Romantic Agony, en van 'verontrustende' $18^{\mathrm{e}}$ en $19^{\mathrm{e}}$-eeuwse verhalen uit diverse landen in de bloemlezing Afgronden (1997). Zelf schreef hij de gotieke roman Het paradijs (1993).

${ }^{6}$ Van Kempen en Mertens (1993) speculeerden over 'een stroming [...] van vrouwelijke auteurs als Dorrestein, Hemmerechts en De Martelaere die in hun verhalen voortborduurden op de traditie van de gothic novel [...]' (p. 15). Zie ook Kuiper (1992). Behalve Brijs, Claus, De Coster en Hemmerechts zijn de Vlamingen vertegenwoordigd met de 'Kempische gothic' van Felix Timmermans (de term is van Overstijns 1997), vroege verhalen van Ward Ruyslinck, Johan Daisne (door Weisgerber (1976) aangeduid als gothic (p. 160. e.v.)) en Jef Geeraerts' Sanpaku (1989). Indisch: W. Bastiaans' verzameling Indische spookverhalen Seram (1970), Alfred Birney's Vogels rond een vrouw (1991), Bas Heijnes 'Vlees en bloed' (1986), of het verhaal 'Onbekenden' van Vincent Mahieu (door Hans Warren 'een typisch Indisch gruwel- en spookverhaal'genoemd (Warren 1989a)). In de jeugdliteratuur is Paul van Loon onbetwiste aanvoerder. Non-fictie: Mensje van Keulen legt in Lach van Schreck (1991) een grote belangstelling voor vampiers aan de dag en Ethel Portnoy onderzocht de vampiermythe in haar Dromomania (1987).
} 


\section{BIBLIOGRAFIE}

Alphen, Ernst van, Bij wijze van lezen. Verleiding en verzet van Willem Brakmans lezer. Muiderberg: Coutinho 1988.

Alphen, Ernst van, 'Naar een theorie van het postmodernisme, over de postmoderne postmodernisme discussie'. Forum der letteren 30 (1989), 21-37.

Alphen, Ernst van, De toekomst der herinnering. Essays over moderne Nederlandse literatuur. Amsterdam: Van Gennep, 1993.

Alphen, Ernst van, 'Mannen onder mekaar. Volgens Ian McEwans "The Comfort of Strangers".' Tijdschrift voor Vrouwenstudies 15, no. 3 (1994), 339-355.

Amsberg, Ariane, Wat vrouwen zelf van seks vinden. Amsterdam: Bert Bakker, 1977.

Anbeek, Ton, Het donkere hart. Romantische obsessies in de moderne Nederlandstalige literatuur. Amsterdam: Amsterdam University Press, 1996.

Andere Tijden, 'Het Boekenweekgeschenk van Reve.' (VPRO, 8 maart 2001), http://geschiedenis.vpro.nl/programmas/2899536/afleveringen/3490389/ geraadpleegd 27 januari 2010.

Andeweg, Agnes, 'Renate Dorrestein'. In: Thomas Vaessens en Jacqueline Bel (red.), Schrijvende Vrouwen. Een kleine literatuurgeschiedenis van de Lage Landen. Amsterdam: Amsterdam University Press, 2010.

Andeweg, Agnes, 'Time and again: anachronism and the gothic'. In: E. Wesseling \& R. Zwijnenberg (eds.), Art in Time: on the Use and Abuse of Anachronisms in the History of Art. London: Equinox Ltd., forthcoming.

Andeweg, Agnes, 'The Ghost in the Closet. Frans Kellendonk and the Gothic'. In: I. van Elferen (ed.), Nostalgia or Perversion? Gothic Rewriting from the Eighteenth Century until the Present Day. Newcastle: Cambridge Scholars Publishing, 2007, 138-152.

Andeweg, Agnes, (2007a), 'Het spook van de homoseksualiteit. Kellendonks Letter en Geest gelezen als gotieke roman. In: Elke Brems e.a. (red.), Achter de verhalen. Over de Nederlandse literatuur van de twintigste eeuw. Leuven: Uitgeverij Peeters, 2007, 322-335.

Andeweg, Agnes, (2007b), 'Een verhaal moet niet te vroeg klaarkomen. Reves parodie van heteroseksuele mannelijkheid'. Armada 13 (2007) 48 (oktober), 32-41.

Andeweg, Agnes, 'Spookverhalen. Over gothic en gender'. Lover 33/2 (jun 2006), 22-26.

Andeweg, Agnes, 'Bij hoog en bij laag. Het gotieke in Thomas Rosenbooms Vriend van verdienste', Nederlandse letterkunde, 10 (2005) 1 (feb), 17-34.

Anker, Robert, 'Het meisje en de tweeling: een Iers verhaal van Vonne van der Meer'. Het Parool, 29 september 1995.

Armstrong, Nancy, How Novels Think. The Limits of Individualism from 1719-1900. New York: Columbia University Press, 2005. 
Armstrong, Nancy (2005a), 'Feminism, Fiction and the Utopian Promise of Dracula.' Differences 16/1 (2005), 1-23.

Atwood, Margaret, Payback. Debt and the Shadow Side of Wealth. Londen: Bloomsbury, 2008.

Aydemir, Murat, “Significant Discharge”: the cum shot and narrativity.' In: Mieke Bal (ed.) Narrative Theory. Critical Concepts in Literary and Cultural Studies. Vol 3, London \& New York: Routledge 2004, 297-318.

Ayers, Mary, Mother-Infant Attachment and Psychoanalysis. Hove \& New York: BrunnerRoutledge, 2003.

Backus, Margot Gayle, The Gothic Family Romance: Heterosexuality, Child Sacrifice and the AngloIrish Colonial Order. Durham: Duke University Press, 1999.

Baldick, Chris and Robert Mighall, 'Gothic Criticism'. In: Punter, D. (ed.), A Companion to the Gothic. Oxford: Blackwell Publishers, 2000, 209-229.

Bartels, Thijs en Jos Versteegen, Homo-encyclopedie van Nederland. Amsterdam: Anthos, 2005.

Bax, Sander, 'Een postmodern revisor? De relatie tussen het Revisor-proza en het postmodernisme'. Vooys 19 (2001) 1, 24-33.

Bax, Sander, 'Het literaire tijdschrift De Revisor en het postmodernisme. Reactie op een beschouwing van Jaap Goedegebuure.' Nederlandse letterkunde 7 (2002), 152-156.

Becker, J.W. en R. Vink, Secularisatie in Nederland, 1966-1991: de verandering van opvattingen en enkele gedragingen. Rijswijk, Den Haag: Sociaal en Cultureel Planbureau/VUGA, 1994.

Becker, J.W. en J.S.J. de Wit, Secularisatie in de jaren negentig: kerklidmaatschap, veranderingen in opvattingen en een prognose. Den Haag: Sociaal en Cultureel Planbureau, 2000.

Becker, Susanne, Gothic Forms of Feminine Fictions. Manchester and New York: Manchester University Press, 1999.

Beekman, Klaus, 'Omtrent "Lieve Jongens" en "De vierde man". Twee boeken, twee films'. Bzzlletin 15 (1986) 138 (sep), 3-11.

Beekman, Klaus en Mia Meijer, Kort Revier. Gerard Reve en het oordeel van zijn medeburgers. Amsterdam: Erven Thomas Rap/Athenaeum-Polak \& Van Gennep, 1973.

Beer, E.S. de, 'Gothic: Origin and Diffusion of the Term; The Idea of Style in Architecture'. Journal of the Warburg and Courtauld Institutes, Vol. 11. (1948), 143-162.

Beerman, K., De Baarnse moord: achtergronden, feiten, reconstructie, berechting. Beverwijk: de Kennemer, 1963.

Berg, Willem van den, 'Sara Burgerhart en haar derde stem'. Documentatieblad Blad Werkgroep Achttiende Eeuw, 51/52, sept 1981, 151-207.

Berger, Peter L., The Sacred Canopy: elements of a sociological theory of religion. New York: Anchor Books, 1990 [1969].

Berger, Peter L., The desecularization of the world: resurgent religion and world politics. Washington: Ethics and Public Policy Center, 1999.

Bervoets, Jan, 'Alexander Ver Huell en zijn fantastisch verhaal "No. 470, Hoogewoerd"'. Revisor 9 (1982), 30-40.

Billiani, Francesca \& Giglioa Sulis (red.), The Italian Gothic and Fantastic: Encounters and Rewritings of Narrative Traditions. Cranbury, NJ: Associated University Press, 2007.

Blaas, P.B.M., Anachronisme en historisch besef. Momenten uit de ontwikkeling van het Europees Historisch Bewustzijn. Den Haag: Universitaire Pers Rotterdam, 1988.

Blink, Inge van den, 'Nieuwste roman van Renate Dorrestein: bizar en meeslepend'. Nieuwsblad van het Noorden. 13-06-1986.

Boelaars, Bert, Koninklijke jaren. De Weerter periode van Gerard Reve. Amsterdam: L.J. Veen, 2002.

Boon, Tijn, Het koppige hoofd dat niet wilde scheuren. Amsterdam: Meulenhoff, 1998. 
Bosboom, Rolf, Zuilen van stof. Het oeuvre van Frans Kellendonk. Nijmegen: Quine, 1994.

Botting, Fred, Gothic. The New Critical Idiom. New York, London: Routledge, 2001 [1996].

Botting, Fred, Gothic Romanced. Consumption, Gender and Technology in Contemporary Fictions. New York, London: Routledge, 2009.

Bourke, Joanna, Fear. A Cultural History. London: Virago, 2005.

Bousset, Hugo, 'Roze anus en witte suiker. Over Thomas Rosenboom en D.A.F. de Sade'. In: Idem, Geritsel van papier: Essays. Amsterdam: Meulenhoff, 1996, 18-37.

Bouw, Marjan de, 'Alice in wonderland', De Standaard, 07-03-1987.

Brabon, Benjamin \& Stephanie Genz, 'Introduction. Postfeminist gothic'. Gothic Studies 9 (2007) 2 (Nov), 1-6.

Braches, Ernst, Engel en afgrond. Over The Turn of the Screw van Henry James. Voorwoord door Frans Kellendonk. Amsterdam: Meulenhoff, 1983.

Braidotti, Rosi, Metamorphoses. Towards a Materialist Theory of Becoming. Cambridge etc.: Polity Press, 2002.

Brakel, L.J. van en J.T. van den Brink, Filosofie van de wetenschappen. Muiderberg: Coutinho, 1988.

Brakman, Willem, Glubkes oordeel \& Over het monster van Frankenstein. Amsterdam: Querido, 1976.

Brannigan, John, New Historicism and Cultural Materialism. London: MacMillan, 1998.

Breedt Bruyn, Martje, 'Een overdosis van het sprookjesachtige: avonturenroman van Renate Dorrestein'. Vrij Nederland, 28-06-1986.

Brems, Hugo, 'Alles moet anders: vier polemieken rond 1980'. In idem: Altijd weer vogels die nesten beginnen. Geschiedenis van de Nederlandse literatuur 1945-2005. Amsterdam: Bert Bakker, 2006, 372-379.

Brewster, Scott, 'Seeing Things: Gothic and the Madness of Interpretation'. In: Punter, D. (ed.), A Companion to the Gothic. Oxford: Blackwell Publishers, 2000, 281-292.

Bridgwater, Patrick, De Quincey's Gothic Masquerade. Amsterdam/New York: Rodopi, 2004.

Briggs, Julia, Night Visitors. The Rise and Fall of the English Ghost Story. London: Faber \& Faber, 1977.

Briggs, Julia, 'The Ghost Story'. In: David Punter (ed.), A Companion to the Gothic. Oxford: Blackwell Publishers, 2000, 122-132.

Brinks, Ellen, Gothic Masculinity: Effeminacy and the Supernatural in English and German Romanticism. Lewisburg: Bucknell University Press, 2003.

Bronfen, Elisabeth, Over Her Dead Body. Death, femininity and the aesthetic. Manchester: Manchester University Press, 1992.

Bronfen, Elisabeth, 'Femme fatale / Negotiations of Tragic Desire'. New Literary History 35 (2004), 1, 103-116.

Brooks, Peter, Reading for the Plot: Design and Intention in Narrative. Cambridge, MA \& London: Harvard University Press, 1992 [1984].

Brongersma, E., 'De Baarnse moordzaak.' Nederlands tijdschrift voor criminologie, vol 6 (1964), 820 en 33-47. Reacties van Johan Fabricius 119-121; door I.M.A. Donker-Rutgers 121-123; naschrift door Brongersma 123-124.

Brontë, Charlotte, Jane Eyre. Harmondsworth, Middlesex etc: Penguin, 1985 [1847].

Bruhm, Steven, Gothic Bodies. The Politics of Pain in Romantic Fiction. Philadelphia: University of Pennsylvania Press, 1994.

Buijnsters, P., 'Betje Wolff en Aagje Deken'. In: Anton Korteweg en Murk Salverda (red.), 't Is vol van schatten hier. . . . Deel 1: Nederlandse literatuur van 1750 tot 1940 tentoongesteld in het Letterkundig Museum. Amsterdam: De Bezige Bij, 1986, 12-13. 
Buikema, Rosemarie, 'Monsterlijke liefdes. De gothic novel in het werk van Ruebsamen'. Bzzlletin 224, maart 1995, 46-54.

Buikema, Rosemarie, 'De stilte rond Bertha Mason. Postkoloniale interpretaties van Charlotte Brontës Jane Eyre.' Tijdschrift voor Vrouwenstudies, 72, oktober 1997, 400-418.

Buikema, Rosemarie, 'De verborgen kamers van de literaire cultuur'. In L. Duyvendak \& B. van Heusden (Eds.), Literaire cultuur, casusboek. Nijmegen: SUN, 2001, 49-62.

Buikema, Rosemarie, 'Verborgen kamers: motieven in de gothic novel'. In: Passionate: literairfilosofisch maandblad voor de rusteloze Nibilist, 10 (2003), 3 (mei-juni), 6-9.

Buikema, Rosemarie, 'De gotieke vertelling in Hella S. Haasses De Verborgen Bron en Sleuteloog'. In: Vooys. Tijdschrift voor Letteren. Jaargang 21 (2003a) nr 3/4, 189-196.

Buikema, Rosemarie en Lies Wesseling, 'De representatie van het moederschap in verlichte opvoedkunde en duistere gothiek', in: Spiegel der Letteren. Themanummer: De gedeelde werkelijkheid van wetenschap, cultuur en literatuur 42 (2000) 2, 156-174.

Buikema, Rosemarie en Lies Wesseling, Het Heilige Huis. De gotieke vertelling in de Nederlandse literatuur. Amsterdam: Amsterdam University Press, 2006.

Buikema, Rosemarie en Lies Wesseling (2006a), 'Verschijningsvormen van de gotieke vertelling in de negentiende-eeuwse literatuur'. Parmentier 15 (2006) (4), 95-113.

Buikema, Rosemarie en Elisabeth Wesseling, 'Gothic Engineerings in Childrearing Manuals and Feminist Novels: Benjamin Spock Meets Renate Dorrestein'. In: Isabella van Elferen (ed.), Nostalgia or Perversion? Gothic Rewriting from the Eighteenth Century until the Present Day. Newcastle: Cambridge Scholars Publishing, 2007, 152-167.

Buisman, J. Fzn., M., Populaire prozaschrijvers van 1600 tot 1815: romans, novellen, verhalen, levensbeschrijvingen, arcadia's, sprookjes: alphabetische naamlijst. Met: lijst van ridder-, rover, en verschrikkingsromans tot 1900. Amsterdam: Israël, 1960.

Butler, Judith, Gender Trouble. Feminism and the Subversion of Identity. New York, London: Routledge, 1999, $10^{\text {th }}$ edition. [1990].

Butler, Judith, 'Capacity'. In: Stephen M. Barber \& David L. Clark, Regarding Sedgwick. Essays on Queer Culture and Critical Theory. New York etc: Routledge, 2002, 109-121.

Butler, Judith, Undoing Gender. New York etc.: Routledge, 2004.

Butterfield, Herbert, The Whig Interpretation of History. New York: Norton, 1965 [1931].

Byron, Glennis \& David Punter, Spectral Readings. Towards a Gothic geography. New York, London: Palgrave, 1999.

Castle, Terry, The Apparitional Lesbian. Female Homosexuality and Modern Culture. New York: Columbia University Press, 1993.

Castle, Terry, The Female Thermometer. Eighteenth Century Culture and the Invention of the Uncanny. New York: Oxford University Pres, 1995.

Cavell, Stanley 1988. 'The uncanniness of the ordinary'. In: idem, In quest of the ordinary 1988. Chicago: University of Chicago Press, 153-178.

Chabot, Sean \& Jan Willem Duyvendak, 'Globalization and transnational diffusion between social movements: reconceptualizing the dissemination of the Ghandian repertoire and the "coming out" routine.' Theory and Society 31 (2002), 697-740.

Clery, E.J., 'Against Gothic'. In: Allan Lloyd-Smith and Victor Sage (eds.), Gothick Origins and Innovations. Amsterdam etc.: Rodopi Press, 1994, 34-43.

Clery, E.J., The Rise of Supernatural Fiction 1762-1800. Cambridge: Cambridge University Press, 1995.

Clery, E. J., Women's Gothic: From Clara Reeve to Mary Shelley. Writers and Their Work Series. Tavistock: Northcote, 2000. 
Clery, E.J. en R. Miles (eds.), Gothic Documents. A Sourcebook 1700-1820. Manchester: Manchester University Press 2000.

Corporaal, Marguérite, 'Peter Brooks.' In: Anneleen Masschelein en Dirk de Geest (red.), Engelstalige literatuur na 1945. Deel 3: Kritiek, theorie en essay. Leuven: Peeters 2006, 97-113.

Costera Meijer, Irene, Het persoonlijke wordt politiek. Feministische bewustwording in Nederland 1965-1980. Amsterdam: Het Spinhuis, 1996.

Cox, Jeffrey (ed.), Seven Gothic Dramas. 1789-1825. Athens: Ohio University Press, 1992.

Culler, Jonathan, Literary Theory: a Very Short Introduction. Oxford, New York: Oxford University Press, 1997.

Currie, Mark, ed. Metafiction. New York: Longman Group, 1995.

Daenen, M., Nederlandse fantastische literatuur: vier fantastische novellen geanalyseerd en vergeleken met secundaire literatuur over het fantastische in het Nederlands. Doctoraalscriptie Universiteit van Amsterdam, 1984.

Dautzenberg, J.A., 'Over de thematiek van Bordewijks korte verhalen.' Spiegel der Letteren 21 (1979), 178-196.

Day, William Patrick, In the Circles of Fear and Desire: A Study of Gothic Fantasy, Chicago: University of Chicago Press, 1985.

De kunst van het vrijen. 's-Gravenhage: NVSH, 1977.

Delamotte, Eugenia C., Perils of the Night: A Feminist Study of Nineteenth-Century Gothic (1990).

Dentith, Simon, Parody. London etc.: Routledge, 2000.

Derks, Will, 'Een Blauwe Christus. Over Reve en Indië. Revisor 29 (2002) 4 (nov), 109-134.

Dever, Carolyn, Death and the Mother from Dickens to Freud. Victorian Fiction and the Anxiety of Origins. Cambridge: Cambridge University Press, 1998.

Dewaide, Philomene, 'Kellendonks Letter en Geest en de mythe van Phaëton'. Vooys, 13 (1995) 3 (mei/juni), 18-24.

Diepstraten, Johan, ' Een modern Indisch spookverhaal' [over Vogels rond een vrouw van Alfred Birney], De Stem 12 juli 1991.

Dierickx, Arno, Bloedbroeders (film), 2008.

Dijkhuis, J.L., 'Stoute jongen. Enkele motieven in Reves werk'. Bzzlletin 14/132 (jan 1986), 6676.

Dijkstra, Bram, Idols of Perversity: Fantasies of Feminine Evil in Fin-de-siècle Culture. New York, Oxford: Oxford University Press, 1986.

Dijkstra, Bram, Evil Sisters. The Threat of Female Sexuality in Twentieth-Century Culture. New York: Henry Holt and Company, 1998 [1996].

Doorman, Maarten, De romantische orde. Amsterdam: Bert Bakker, 2004.

Dorrestein, R., 'Daar valt weer iemand, maar mijn pen geeft haar nog net op tijd vleugels'. In: De Tijd 20-11-1987, 50-55.

Dorrestein, Renate, Het perpetuum mobile van de liefde. Amsterdam: Contact, 2002 [1988].

Dorrestein, Renate, Noorderzon. Amsterdam: Contact 1997 [1986].

Dorrestein, Renate, Het geheim van de schrijver. Amsterdam: Contact, 2000.

Douglas, Mary, Purity and Danger. An Analysis of Concepts of Pollution and Taboo. London: Routledge \& Kegan Paul, 1966.

Dullaart, Leo, 'Homoseksualiteit als openbaar lichaam'. In: Jaap Goedegebuure (red.), Het verdeelde lichaam. Ervaring en verbeelding van lichamelijkheid in een gefragmenteerde cultuur. Baarn: Gooi en Sticht, 1994, 151-164.

Dunk, H.W. von der, e.a. (red)., Wederopbouw, welvadrt en onrust. Nederland in de jaren vijftig en zestig. Houten: De Haan, 1986.

Duyvendak, Jan Willem (red.), De verzuiling van de homobeweging. Amsterdam: SUA, 1994. 
Duyvendak, Jan Willem, 'Be gay, ofwel een lichte verplichting tot vrolijkheid. Enkele observaties over het actierepertoire van de homobeweging. In: Marian van der Klein en Saskia Wieringa (red.), Alles kon anders. Protestrepertoires in Nederland 1965-2005. Amsterdam: Aksant 2006, 145-159.

Duyvendak, Jan Willem en Menno Hurenkamp (red.), Kiezen voor de kudde. Lichte gemeenschappen en de nieuwe meerderheid. Jaarboek Tijdschrift voor de Sociale Sector. Amsterdam: Van Gennep, 2004.

Dyer, Richard, 'Seen to be Believed: Some Problems in the Representation of Gay People as Typical'. In: idem, The Matter of Images: Essays on Representations. London and New York: Routledge, 1993, 19-51.

Dyer, Richard, 'Coming Out as Going In: the Image of the Homosexual as a Sad Young Man'. In: idem, The Matter of Images: Essays on Representations. London and New York: Routledge, 1993, 73-91.

Eck, Mieske van, 'Laatste roman Noorderzon is spannend en geestig: Renate Dorrestein overtreft zichzelf. Brabants Nieuwsblad, 02-06-1986.

Ejlersen, Mette, Orgasme bij de vrouw. 's-Gravenhage: NVSH, 1972 (uit het Deens vertaald).

Elferen, Isabella van, 'Introduction: Nostalgia and Perversion in Gothic Rewriting'. In: I. van Elferen (ed.), Nostalgia or Perversion? Gothic Rewriting from the Eighteenth Century until the Present Day. Newcastle: Cambridge Scholars Publishing, 2007, 1-12.

Ellis, Albert, Plezier met sex. 's-Gravenhage: NVSH, 1967.

Ellis, Kate Ferguson, The Contested Castle. Gothic Novels and the Subversion of Domestic Ideology. Urbana and Chicago: University of Illinois Press, 1989.

Ellis, Kate Ferguson, 'Can you forgive her? The Gothic heroine and her critics'. In: David Punter (ed.), A Companion to the Gothic. Oxford: Blackwell Publishers, 2000, 257-268.

Eugelink, Liesbeth, Niets in mij gelooft dat. Over religie in de moderne Nederlandse literatuur. Baarn: Ten Have, 2007.

Fabricius, Johan, Jongensspel. Den Haag: H.P. Leopolds Uitgeversmij, 1963.

Felman, Shoshana, 'Turning the Screw of Interpretation'. In: idem, Literature and Psychoanalysis: The Question of Reading: Otherwise. Baltimore: Johns Hopkins University Press, 1982, 94207.

Fitzgerald, Lauren, 'Female Gothic and the Institutionalization of Gothic Studies'. Gothic Studies 6/1 (May 2004), 8-18.

Fleenor, Julian E. (ed.), The Female Gothic. Montreal: Eden Press, 1983.

Foucault, Michel, De wil tot weten. Geschiedenis van de seksualiteit I. Nijmegen: SUN,1984.

Fowler, Alastair, Kinds of Literature. An introduction to the theory of genres and modes. Oxford: Clarendon Press, 1982.

Frank, Adam, 'Phantoms Limn. Silvan Tomkins and Affective Prostethics'. Theory and Psychology 17 (2007) 4 (Winter): 515-528.

Freud, Sigmund, 'Das Unheimliche'. Psychologische Schriften. Studienausgabe Band IV. S. Fischer Verlag, 1989 [1919], 243-274.

Fritzsche, Peter, 'Specters of History: On Nostalgia, Exile, and Modernity'. American Historical Review 106 (2001) (dec), 1587-1618.

Fuchs, Barbara, Romance. The New Critical Idiom. New York, London: Routledge 2004.

Gaigher, Louis, 'Alice in die kasteel van Udolpho: Renate Dorrestein se diaboliese sprokies'. In: Tydskr. Ned. Afr. Temanommer: Gauting en die Lae Lande; 7 (2000), 2, 131-147.

Gamer, Michael, Romanticism and the Gothic. Cambridge: Cambridge University Press, 2000.

Garber, Marjorie, Vested interests. Cross-dressing and cultural anxiety. London etc: Penguin Books, 1993 [1992]. 
Gard, Roger, (ed.), The Critical Muse. Selected Literary Criticism. London: Penguin, 1987.

Garlick, S., 'What is a Man? Heterosexuality and the Technology of Masculinity'. Men and Masculinities, Vol. 6, No. 2, 156-172 (2003).

Gay, Peter, Sigmund Freud. Zijn leven en werk. Baarn: Tirion, 1988.

Geest, Joost de, Motieven en technieken van de fantastische novelle in de Nederlandse letterkunde in de $20^{\circ}$ eeuw. Dissertatie Brussel, 1973.

'Gelezen en geknipt'. Vriendschap, mei 1964 (19 jaargang), 105.

Gilbert, Sandra \& Susan Gubar, The Madwoman in the Attic: The Woman Writer and the Nineteenth-Century Literary Imagination. New Haven etc: Yale University Press, 1979.

Goddu, Teresa A., Gothic America: Narrative, History, and the Nation. New York: Columbia University Press, 1997.

Goedegebuure, Jaap, 'Een omkeerbare jacobsladder.' Haagse Post, 13 maart 1982.

Goedegebuure, Jaap, 'Bos, bronst en bliksem’ Haagse Post, 01-02-1986.

Goedegebuure, Jaap, 'Dan moet hij er toch zijn als ik hem zoek (over literatuur en religie)'. In: idem, Nederlandse literatuur 1960-1988. Amsterdam: De Arbeiderspers 1989, 223-245.

Goedegebuure, Jaap, 'Het tweeslachtig mechanisme'. HP/De Tijd, 6 oktober 1995.

Goedegebuure, Jaap, 'Jacobsladders. Over Frans Kellendonk'. In: idem, De veelvervige rok. Amsterdam 1997, 116-133.

Goedegebuure, Jaap, 'Postmoderne modernisten en modernistische postmodernen. Nederlandstalige schrijvers van de twintigste eeuw herlezen.' Nederlandse letterkunde 6 (2001) 1, 1331.

Goedegebuure, Jaap, 'Hoe giert de Bulderbast om 't graf.' Trouw, 3 januari 2004.

Goedkoop, Hans, Een verhaal dat het leven moet veranderen. Amsterdam: Augustus, 2004.

Gorp, Rik van, 'Het succes van de 'gothic novel': enkele vertalingen en 'bewerkingen' van Radcliffes 'The Italian' In: Luc Herman, Geert Lernout, Paul Pelckmans (red.), Veertien listen voor de literatuur: huldeboek aangeboden aan Prof. dr. Clem Neutjens. Kapellen: Pelckmans, 1993, 136-153.

Gorp, Hendrik van, De romantische griezelroman (Gothic novel). een merkwaardig randverschijnsel in de literatuur. Leuven-Apeldoorn: Garant, 1998.

Gorp, Hendrik van, 'De receptie van de gothic novel in de Nederlandse literatuur (1790-1850). In: H. van Gorp (red.), Grensverkeer: literatuurwetenschap, tekstinterpretatie, cultuurstudie. Leuven: Peeters 1999, 173-197.

Gorp, Hendrik van, 'Populaire verhaalkunst, genreproblematiek en academische literatuurstudie.' In: Liesbeth Korthals Altes en Dick Schram (red.), Literatuurwetenschap tussen betrokkenheid en distantie. Assen: Van Gorcum 2000, 41-49.

Grunenberg, Christoph (ed), Gothic. Transmutations of Horror in Late Twentieth Century Art. Boston: Inst. of Contemporary Art \& Cambridge MA: MIT, 1997.

Haasse, Hella, 'De gothic novels van Renate Dorrestein', in: Lezen achter de letters. Amsterdam: Querido, 2000, 283-295. Oorspronkelijk verschenen als: 'Bij de "Gothieke vertelsels" van Renate Dorrestein'. In Bzzlletin 166-167 (mei-juni 1989), 36-42. Ook in: Bulkboek: 24 (1996) 234, 22-29.

Hafkamp, Hans, “'Hij heeft voor mij van pijn gezongen / Bij elke zweepslag op zijn kont”. Notities over slaan en homo-erotiek'. Bzzlletin 21 (1991/1992) 188 (sept 1991), 14-25.

Haggerty, George E., Gothic Fiction/Gothic Form. University Park and London: Pennsylvania State University Press, 1989.

Haggerty, George E., Queer Gothic. Urbana \& Chicago: University of Illinois Press, 2006.

Halberstam, Judith, Skin Shows. Gothic Horror and the Technology of Monsters. Durham: Duke University Press, 1995. 
Hall, D., French and German Gothic Fiction in the Late Eighteenth Century. Oxford: Lang. 2005.

Halsema, Annemie, 'Judith Butler: turbulentie op het gebied van gender en seksualiteit'. In Judith Butler, Gender turbulentie. Amsterdam: Boom/Parrèsia, 2000, 7-29.

Haraway, Donna, Modest_Witness@Second_Millennium. FemaleMan@O_Meets_OncoMouse ${ }^{T M}$ : Feminism and Technoscience. New York, London: Routledge, 1997.

Hart, Maarten 't, 'Dodo's en druipsteengrotten: roman van Renate Dorrestein.' NRC Handelsblad, 30 mei 1986.

Haslam, Richard, 'Irish Gothic'. In: Catherine Spooner \& Emma McEvoy, Routledge Companion to Gothic. London \& New York etc.: Routledge, 2007, 83-94.

Hayles, N. Katherine, 'Voices out of Bodies, Bodies out of Voices: Audiotape and the Production of Subjectivity'. In: Adalaide Morris, Sound States: Innovative Poetics and Acoustical Technologies. Chapel Hill, NC. 1997. 74-96.

Heijst, Annelies van, Leesbaar lichaam. Verhalen van lijden bij Blaman en Dorrestein. Kampen: Kok/Agora, 1993.

Heiland, Donna, Gothic and Gender. An Introduction. Oxford etc.: Blackwell, 2004.

Hekma, Gert, “ . . . Een man zo wreed en geil ..."? Aantekeningen over wreedheid en herenliefde bij Reve en Sade'. In: Arnold Greidanus en Hans Hafkamp (red.), Reve Jaarboek 3. [s.l.] De Prom, 1986, 48-57.

Hekma, Gert, 'De meedogenloze jongen. Homoseksualiteit en sadomasochisme in het werk van Gerard Reve.' In: Vincent Hunink, Jos Paardekooper, Paul Sars (red. ), Eigenlijk geloof ik niets. Essays over het werk van Gerard Reve. Nijmegen: Uitgeverij Cadans, 1990, 51-65.

Hekma, Gert, Homoseksualiteit in Nederland van 1730 tot de moderne tijd. Amsterdam: Meulenhoff, 2004.

Heller, Tamar, Dead secrets. Wilkie Collins and the female gothic. New Haven [etc.]: Yale University Press, 1992.

Hendershot, Cyndy, The Animal Within. Masculinity and the Gothic. Ann Arbor: University of Michigan Press, 2003.

Herman, Luc en Bart Vervaeck, Vertelduivels. Handboek verhaalanalyse. Brussel \& Nijmegen: VUBPress \& Vantilt, 2002.

Hermans, Mariëtte, 'Een per ongeluk gepleegde moord. Het beeld van Ierland in twee moderne Nederlandse romans'. In: Surplus, jrg $10 \mathrm{nr} 5$ (1996), 10-11.

Heumakers, Arnold, 'Een literair spook'. De Volkskrant 23 maart 1982.

Heumakers, Arnold, Schoten in de concertzaal. Over literatuur, politiek en het Kwaad. Amsterdam: Arbeiderspers, 1993.

Heumakers, Arnold, en Willem Kuipers, 'Goden en mindere goden'. In: Maatstaf 39 (1991) 8-9: $2-12$.

Hilberts, Ina, Zwarte romantiek in Nederland? Doctoraalscriptie Vrije Universiteit Amsterdam, 1986.

Hillis Miller, J., Fiction and Repetition. Seven English Novels. Oxford: Basil Blackwell, 1982.

Hirsch, Marianne, 'Ideology, Form, and "Allerleirauh": Reflections on Reading for the Plot', Children's Literature, 14, 1986, 163-168.

Hobsbawm, Eric, The Invention of Tradition. Cambridge: Cambridge University Press, 1983.

Hodkinson, Paul, Goth. Identity, Style and Subculture. Oxford: Berg, 2002.

Hoekstra, Hanneke, The Orthodoxy of the Heart. Faith, Fryslann, and Feminism in the Novels of Ypk fan der Fear. Grins/Groningen: Stifting FFYRUG, 1998.

Hoeveler, Diane Long, Gothic Feminism: The Professionalization of Gender from Charlotte Smith to the Brontës. University Park: Penn State Press, 1998. 
Hogle, Jerrold, 'The Ghost of the Counterfeit in the Genesis of the Gothic'. In: Allan LloydSmith and Victor Sage (eds.), Gothick Origins and Innovations. Amsterdam etc.: Rodopi Press, 1994, 23-33.

Holbrook, Wm. C., 'The Adjective Gothique in the XVIIIth Century'. Modern Language Notes, Vol. 56, No. 7 (Nov. 1941), 498-503.

Holland, Norman \& Leona F. Sherman, 'Gothic Possibilities', New Literary History 8 (1977): 278-294.

Homeros, Odysseia. De reizen van Odysseus. Vertaald door Imme Dros. Amsterdam: AthenaeumPolak \& Van Gennep, 1995.

Hoof, Aafke van, 'Een toets der kritiek'. Vooys, 16 (1998) 2 (april), 4-14.

Horner, Avril (ed.), European Gothic. A Spirited Exchange 1760-1960. Manchester: Manchester University Press, 2002.

Horner, Avril and Sue Zlosnik, Gothic and the Comic Turn. Houndmills, Basingstoke: Palgrave Macmillan, 2005.

Horner, Avril \& Sue Zlosnik, 'Strolling in the Dark: Gothic Flânerie in Djuna Barnes' Nightwood.' In: Andrew Smith \& Jeff Wallace (eds.), Gothic Modernisms. Houndmills: Palgrave, 2001, 78-94.

Howard, Jacqueline, Reading Gothic Fiction: A Bakhtinian Approach. Oxford: Clarendon Press, 1994.

Houston, Gail Turley. From Dickens to Dracula: Gothic, Economics, and Victorian Fiction. New York and Cambridge: Cambridge University Press, 2005.

Hughes, William, "Who is the third who walks always beside you?" Eliot, Stoker and Stetson in The Waste Land'. In Avril Horner and Sue Zlosnik (eds), Le Gothic: Influences and Appropriations in Europe, 151-166.

Hughes, William and Andrew Smith (eds.), Queering the Gothic. Manchester: Manchester University Press, 2009.

Hurley, Kelly, 'Abject and grotesque'. In: Catherine Spooner \& Emma McEvoy, The Routledge Companion to Gothic. London \& New York etc.: Routledge 2007, 137-147.

Hutcheon, Linda, A Theory of Parody: the Teachings of Twentieth Century Art Forms. Londen: Methuen, 1985.

Hutcheon, Linda, 'Irony, Nostalgia, and the Postmodern'. In: Estor, Annemarie \& Raymond Vervliet (eds.), Methods for the Study of Literature as Cultural Memory. [Studies in Comparative Literature 30]. Amsterdam: Rodopi, 2000, 189-207.

James, Henry, Transatlantische vertellingen. Vertaald door en met een nawoord van Frans Kellendonk. Amsterdam: Querido 1983.

Jameson, Fredric, 'Postmodernism, or the cultural logic of late capitalism'. New Left Review 146 (1984), 53-92.

Jentsch, E., 'Zur Psychologie des Unheimlichen'. In: Psychiatrisch-neurologische Wochenschrift 22 (1906), 203-205.

Johnson, Claudia, Jane Austen: Women, Politics and the Novel. Chicago \& London: University of Chicago Press, 1988.

Jonge, A.Th.M. de, Oorspronkelijke gotische romans in Nederland in de periode 1800-1850. Doctoraalscriptie Universiteit van Amsterdam, 1982.

Kaare, P., Erotiek. Amsterdam: Bert Bakker, 1969.

Kagie, R., 'Ik voel me soms net een Lou de Palingboer of Johannes de Doper: interview met Renate Dorrestein'. Vrij Nederland 24-12-1988. 
Kahane, Claire, 'The Gothic Mirror.' In: Shirley Nelson Garner, Claire Kahane \& Madelon Sprengnether (eds.), The (M)Other Tongue: Essays in Feminist Psychoanalytic Interpretation. Ithaca: Cornell University Press, 1986, 334-351.

Kellendonk, Frans, Letter en Geest. Een spookverhaal.In: Idem, Het complete werk. Amsterdam: Meulenhoff, 1992, [1982], 199-291.

Kellendonk, Frans, 'Het werk van de achtste dag. Over de verhalen van F. Bordewijk.' In: Idem, Het complete werk. Amsterdam: Meulenhoff, 1992, 725-749.

Kellendonk, Frans, 'Lijsten en kooien. Henry James en het probleem van de kennis.' In: Idem, Het complete werk. Amsterdam: Meulenhoff, 1992, 749-765.

Kempen, Yves van en Anthony Mertens, 'Onzichtbare betrekkingen: het proza'. In: Nicolaas Matsier e.a. (red.), Het literair klimaat 1986-1992, Amsterdam: de Bezige Bij, 1993, 13-58.

Kemperink, Mary \& Leonieke Vermeer, 'Literatuur en wetenschap: een dynamische en complexe relatie. Enkele theoretische en methodologische overwegingen'. In: Nederlandse letterkunde 13 (2008), 33-66.

Kennedy, James, Nieuw Babylon in aanbouw: Nederland in de jaren zestig. Amsterdam: Boom, 1995.

Kennedy, James, e.a., 'Bouwen aan Babylon: de jaren zestig in discussie.' Sociologische gids, jrg. 44 (1997), nr. 5-6.

Kerr, Carmen, Vrouwen en sex: een handleiding voor vrouwen die plezierige en volwaardige sexuele relaties willen hebben. Vertaald uit het Amerikaans. Amsterdam: Bakker, i.s.m. NVSH, 1978.

Kesteren, Ronald van, Het verlangen naar de Middeleeuwen. De verbeelding van een historische passie. Amsterdam: Wereldbibliotheek, 2004.

Kilfeather, Siobhán, 'The Gothic Novel'. In Wilson Foster, The Cambridge Companion to the Irish Novel. Cambridge, Cambridge University Press, 2006, 78-96.

Killeen, Jarlath, Gothic Ireland: Horror and the Irish Anglican Imagination in the Long Eighteenth Century. Dublin: Four Courts Press, 2005.

Klaar is Kees, maar hoe zit het nou met Marie? 's-Gravenhage: NVSH, 1978.

Klein, Marian van der en Saskia Wieringa (red.), Alles kon anders. Protestrepertoires in Nederland 1965-2005. Amsterdam: Aksant 2006.

Klein, Naomi, No Logo: no space no choice no jobs Taking aim at the brand bullies. New York: Picador 1999.

Kliger, Samuel, The Goths in England. A Study in Seventeenth and Eighteenth Century Thought. Cambridge, MA: Harvard University Press, 1952.

Kloek, J.J. en W.W. Mijnhardt, 'Negentiende-eeuwse lees-cultuur'. De negentiende Eeuw, 14 (23) (1990), 113-132.

Kloek, J.J. en W.W. Mijnhardt, 1800. Blauwdrukken voor een samenleving. . Den Haag: Sdu uitgevers, 2001.

Kloek, Joost, 'Een scheiding van tafel en bed (met verweesde kinderen).Over de Nederlandse literatuur van de achttiende eeuw in Zuid en Noord'. Nederlandse letterkunde 10 (2005) 1 (feb), 1-16.

Koenis, Sjaak, Het verlangen naar cultuur. Amsterdam: Van Gennep, 2008.

Kooijmans, Luuc. Vriendschap en de kunst van het overleven in de zeventiende en achttiende eeuw. Amsterdam: Bert Bakker, 1997.

Koselleck, Reinhart, Vergangene Zukunft. Zur Semantik Geschichtlicher Zeiten. Frankfurt am Main: Suhrkamp Verlag, 1979.

Kossmann, Alfred, 'Tussendoortje van Gerard Reve'. Het Vrije Volk, 19-06-1981 
Kralt, P., 'Kunst als verkenning. Over het werk van Frans Kellendonk'. Maatstaf 36 (1988) nr. 11-12, 113-125.

Krevelen, Laurens van, 'Een giraf in de tuin'. In: C. de Cloet e.a. (red.), 'Oprecht veinzen'. Over Frans Kellendonk. Schrijversprentenboek 43, 85-95.

Kristeva, Julia, Powers of Horror. An Essay on Abjection. New York: Columbia University Press, 1982.

Kuiper, Anne, 'De nachtmerrie van het lot. Kristien Hemmerechts en de "female gothic"'. Lust en Gratie 33 (lente) 1992, 72-83.

Kuipers, Willem, 'De manipulatie van Reve'. de Volkskrant 16 mei 1981.

Kunst, J.C.W., Het zwarte gat van Nederland. Een onderzoek naar het voorkomen van de 'gothic novel' in Nederland van 1780-1840. Doctoraalscriptie Universiteit van Amsterdam, 1978.

Labrie, Arnold, Zuiverheid en decadentie. Over de grenzen van de burgerlijke cultuur in West-Europa 1870-1914. Amsterdam: Uitgeverij Bert Bakker, 2001.

Laqueur, Thomas, Making Sex: Body and Gender from the Greeks to Freud. Cambridge, MA: Harvard University Press, 1990.

Leerssen, Joep, 'Anders dan Engeland. De Ierse literatuur'. In Theo D'Haen (red.), Europa Buitengaats. Koloniale en postkoloniale literaturen in Europese talen. Deel I. Amsterdam: Bert Bakker 2002, 414-438.

Leerssen, Joep, Mere Irish and Fior-Ghael: Studies in the Idea of Irish Nationality, Its Development and Literary Expression Prior to the Nineteenth Century. Cork: Cork University Press, 1996.

Leerssen, Joep, 'The Rhetoric of National Character: A Programmatic Survey'. Poetics Today 21/2 (Summer 2000), 267-292.

Leeuwen, Evert Jan van, Anarchic Alchemists. Dissident Androgyny in Anglo-American Gothic Fiction from Godwin to Melville. Dissertatie, Leiden 2006.

Lévy, Bernard-Henri, La pureté dangereuse. Paris: Grasset, 1994

Lewis, Matthew, The Monk. In: Four Gothic Novels. Oxford: Oxford University Press, 1994, 155445.

Lewis, Paul, Comic Effects: Interdisciplinary Approaches to Humor in Literature. Albany: SUNY Press, 1989.

Ligtenberg, Lucas, en René van Stipriaan, 'Het leven is een kruisdraging. Alcohol en Religie in het werk van Reve'. Optima 3 (1985) 4 (winter), 15-39.

Linders-Nouwens, Joke, 'Noorderzon knap geconstrueerde roman Renate Dorrestein: de waanzin van schuldgevoelens'. Leidsch Dagblad, 31-05-1986.

Linmans, Janus, Legato con amore in un volume. De Leidse Universiteitsbibliotheek in Letter en Geest van Frans Kellendonk. Leiden: Kopwit, 2006.

Lloyd-Smith, Allan and Victor Sage (eds.), Gothick Origins and Innovations. Amsterdam etc.: Rodopi Press, 1994.

Lodewijks, Jaap, 'Schrijver: Vonne van der Meer'. De Gooi- en Eemlander 14-10-1995.

Loggem, Manuel van, Jeugdproces: toneelstuk in drie bedrijven. Amsterdam: De Bezige Bij, 1963.

Longueil, Alfred E., 'The Word "Gothic" in Eighteenth Century Criticism.' Modern Language Notes, Vol. 38, No. 8. (Dec., 1923), 453-460.

Loo, Vilan van de, De vrouw beslist. De tweede feministische golf in Nederland. Wormer: Inmerc, 2005.

Lowenthal, David, The past is a foreign country. Cambridge: Cambridge University Press, 1985.

Lukács, Georg, The Historical Novel. Harmondsworth: Penguin, 1976 [1955].

Luykx, Paul en Pim Slot, Een stille revolutie? Cultuur en mentaliteit in de lange jaren vijftig. Hilversum: Verloren, 1997. 
Madoff, Mark S., 'Inside, Outside, and the Gothic Locked-Room Mystery'. In: Kenneth E. Graham (ed), Gothic Fictions: Prohibition/Transgression. New York: AMS Press, 1989, 4962.

Maes, Kristel, Overzicht en situering van de Nederlandstalige fantastiek. Licentiaatsverhandeling KU Leuven, 1979.

Mak, Geertje, 'Gender in and beyond the Canon, or how to make Women (In)visible in History', in: Siep Stuurman, and Maria Grever, Beyond the Canon. History for the Twenty-First Century. Basingstoke/New York: Palgrave/MacMillan 2007, 128-144.

Marcuse, Herbert, 'The Affirmative Character of Culture'. In: Negations. Essays in Critical Theory. Boston: Beacon, 1969, 88-134.

Masschelein, Anneleen, 'A Homeless Concept. Shapes of the Uncanny in Twentieth-Century Theory and Culture.' Image and Narrative. Online Magazine of the Visual Narrative. Issue 5 The Uncanny, Jan 2003, geraadpleegd 21 november 2009 via http://www.imageandnarrative.be/uncanny/uncanny.htm

Mathijsen, Marita, Nederlandse literatuur in de romantiek 1820-1880. Nijmegen: Vantilt, 2004.

Mathijsen, Marita, 'De Hollandsche natie'. NRC Handelsblad, 19 september 2009.

Matthijsse, André, 'Rosenbooms proza is al te kunstig'. Haagsche Courant, 10 januari 1986.

Maturin, Charles Robert, Melmoth the Wanderer. Harmondsworth, Middlesex etc: Penguin Classics, 2001.

Mayo, Robert D., 'Gothic Romance in the Magazines'. PMLA, Vol. 65, No. 5 (Sep. 1950), $762-$ 789.

McCarthy, Mary, Can there be a Gothic literature? Amsterdam: De Harmonie, 1973.

McCormack, W. J., 'Irish Gothic and After (1820-1945)'. In: Seamus Deane (ed.), The Field Day Anthology of Irish Writing, Vol. II, Derry: Field Day Publications, 1991, 831-854.

Meer, Theo van der, Sodoms zaad in Nederland. Het ontstaan van homoseksualiteit in de vroegmoderne tijd. Nijmegen: SUN, 1995.

Meer, Vonne van der, 'Spookliefde'. Een warme rug. Zo is hij. Spookliefde. Amsterdam: Contact, 2002, 211-287. [Spookliefde oorspronkelijk 1995].

Meeuse, Piet, Oud nieuws. Amsterdam: de Bezige Bij, 1999.

Meijer, Maaike, De lust tot lezen. Nederlandse dichteressen en het literaire systeem. Amsterdam: Sara/Van Gennep, 1988.

Meijer, Maaike, 'De tweede feministische golf en de literatuur. 15 oktober 1976: Anja Meulenbelt publiceert De schaamte voorbij.' in: M.A. Schenkeveld-van der Dussen (red), Nederlandse literatuur. Een geschiedenis. Groningen: Martinus Nijhoff 1993, 819-825.

Meijer, Maaike, Machtige melodieën. Populaire teksten uit de jaren '50 en '60 als bron voor cultuurgeschiedenis. Oratie Universiteit Maastricht, 1999.

Meijer, Maaike, 'The return of Melodrama. After the Great Divide: The Dutch Case'. In: Gillis J. Dorleijn (ed.), New Trends in Modern Dutch Literature. Leuven: Peeters, 2006, 105-125.

Mertens, Anthony, 'Anthony Mertens in gesprek met Thomas Rosenboom'. In: De Revisor, 27 (2000) 1, feb., 19-30.

Meulenbelt, Anja, De schaamte voorbij. Amsterdam: Van Gennep, 1976.

Meulenbelt, Anja, Vrouwen in praatgroepen: weten hoe het voelt. Amsterdam: Nieuwe Linie, 1977.

Meulenbelt, Anja, Voor onszelf. Vanuit vrouwen bekeken: lijf en seksualiteit. Amsterdam: Feministische Uitgeverij Sara, 1979.

Mighall, Robert, A Geography of Victorian Gothic Fiction. Mapping History's Nightmares. Oxford: Oxford University Press, 1999.

Milbank, Alison, Daughters of the House: modes of the Gothic in Victorian fiction. Basingstoke etc.: Macmillan, 1992. 
Milbank, Alison, 'Milton, Melancholy and the Sublime in the "Female" Gothic from Radcliffe to Le Fanu'. Women's Writing. Special Number: Female Gothic Writing, 1/2 (1994), 143160.

Miles, Robert, 'Introduction'. Women's Writing. Special Number: Female Gothic Writing, $1 / 2$ (1994), 131-142.

Miles, Robert, Ann Radcliffe: the Great Enchantress. Manchester: Manchester University Press, 1995.

Miles, Robert, 'Eighteenth Century Gothic'. In: Catherine Spooner \& Emma McEvoy, The Routledge Companion to Gothic. London \& New York etc.: Routledge 2007, 10-19.

Miller, William Ian, The Anatomy of Disgust. Cambridge MA, London: Harvard University Press, 1997.

Miller, Carolyn R., 'Genre as Social Action'. In: Aviva Freedman \& Peter Medway (eds.), Genre and the New Rhetoric. London, Taylor \& Francis, 1994.

Modleski, Tania, Loving with a Vengeance: Mass-produced Fantasies for Women. New York \& London: Routledge, 1982, m.n. hs 3 'The Female Uncanny: Gothic Novels for Women'.

Moerbeek, Toine, Reve tot de vierde macht. Een leesverslag. Nijmegen: Vantilt, 2004.

Moers, Ellen, Literary Women. London: The Women's Press, 1978 [1976].

Monléon, Jose B., A Specter is Haunting Europe: a Sociohistorical Approach to the Fantastic. Princeton NJ: Princeton University Press 1990.

Moor, Wam de, 'Mijn woede richt zich op stereotiepen. In gesprek met Renate Dorrestein.' Bzzlletin 166-167 (mei-juni 1989), 3-16.

Moore, Barrington, Moral Purity and Persecution in History. Princeton NJ: Princeton University Press, 2000.

Morriën, Adriaan, 'Virtuoos van de eenzelvigheid: Thomas Rosenbooms roman Vriend van verdienste'. Vrij Nederland, 1 februari 1986.

Mulder, Hanneke, Literatuur en zelfreflexiviteit: een realistisch perspectief. Leuven/Apeldoorn: Garant, 1992.

Mulder, Reinjan, 'Het levenverwekkende aroom van een soepel gespannen lichaam'. NRC Handelsblad, 17 april 1981.

Mulder, Reinjan, 'Het spook in het boekenmagazijn'. NRC Handelsblad, 26 maart 1982.

Musa, Mark, Dante Alighieri's Divine Comedy: Inferno, Italian Text and Translation. Bloomington: Indiana University Press, 1996.

Mussell, Kay, Women's Gothic and Romantic Fiction: A Reference Guide. Greenwood Press 1981.

Niemeijer, J.C., 'Bordewijk als auteur van het magisch realisme'. De Gids 116 (1953), 347-393.

Nijgh, Lennart, Moord en Doodslag. Twaalf beroemde Nederlandse moordzaken. Schoorl: Conserve, 1991.

Nuis, Aad, 'Onheilig martelaarschap: schrijnende wellust van boete en versterving in roman van Thomas Rosenboom', De Volkskrant, 27 december 1985.

Oakes, Davis A., 'Ghosts in the Machines: The Haunted Castle in the Works of Stephen King and Clive Barker'. Studies in Weird Fiction, 24 (1999), 25-33.

Oever, Annie van den, <Fritzi> en het groteske. Amsterdam: De Bezige Bij, 2003.

Opmeer, Annemarie, 'De club van de zwarte hand: interview met Renate Dorrestein'. In: Passionate, 10 (2003), 3 (mei-juni), 16-19.

Oppelaar, Wim, 'De geheimzinnige werkelijkheid: over Frans Kellendonk en het genre van het spookverhaal'. Vooys, vol. 15 (1997), afl. 1 (feb), 4-13.

Osstyn, Karel, 'De vierde man'. De Standaard, 5 juni 1981.

Osstyn, Karel, 'Een ritje door de hel'. De Standaard, 15-4-1989. 
Otten, Willem Jan, Het wonder van de losse olifanten. Rede tot de ontwikkelden onder de verachters van de christelijke religie. Amsterdam: G.A. van Oorschot, 1999.

Otto, Rudolf, Het heilige: een verhandeling over het irrationele in de idee van het goddelijke en de verhouding ervan tot het rationele. Hilversum: De Boer etc. 1963 [vert van Das Heilige. Über das Irrationale in der Idee des Göttlichen und sein Verhältnis zum Rationalen. (1917)]

Overstijns, Jeroen, 'Felix Timmermans mee naar het volgende millennium? 'Met wat letterkunde in groot genoegen omsierd'. Ons Erfdeel 40 (1997) nr. 5 (nov/dec), 642-653.

Palmer, Paulina, Lesbian Gothic: Transgressive Fictions. London: Cassell, 1999.

Pam, Max, 'Zacht, licht en gelovig met mate'. HP/De Tijd, 13-08-1999.

Paulson, Ronald, 'Gothic Fiction and the French Revolution'. English Literary History 48 (1981), 532-554.

Pattynama, Pamela. 'Maskering en geheimhouding. Het lesbisch verhaal.' In: Margriet Prinssen en Lucie Th. Vermij (red.), Schrijfters in de jaren vijftig. Amsterdam: Sara, 1991, 251-263.

Peeren, Esther, 'The Ghost as a Gendered Chronotope'. In: Sladja Blazan (ed), Ghosts, Stories, Histories: Ghost Stories and Alternative Histories. Newcastle: Cambridge Scholars Publishing, 2007, 81-96.

Pieters, Jürgen, De tranen van de herinnering: het gesprek met de doden. Groningen: Historische Uitgeverij, 2005.

Pieters, Jürgen, (2005a), 'In denkbeeldige tegenwoordigheid. Naar een New Historicism in de Lage Landen?'. Spiegel der Letteren 47/3 (2005), 251-273.

Piryns, Piet, 'Interview met Hugo Claus', Knack, 24-03-1999.

Platzner, Robert L. \& Robert D. Hume, 'Gothic versus Romantic': A Rejoinder. PMLA 86 (1971), 266-274.

Poecke, Luc van, Bijdrage tot de geschiedenis van de Nederlandse huiverroman, Een onderzoek van topoi, themata en motieven. Licentiaatsverhandeling KU Leuven, 1936.

Polak, Johan, 'Het numen in het werk van Gerard Reve.' In: Vincent Hunink, Jos Paardekooper, Paul Sars (red. ), Eigenlijk geloof ik niets. Essays over het werk van Gerard Reve. Nijmegen: Uitgeverij Cadans, 1990, 31-51.

Postma, Dirk Willem, 'Uit de kast, in de kast. Over de waarde van geheimen in de seksuele opvoeding.' In: Vernieuwing 62/10 (december 2003), 12-15

Praz, Mario, The Romantic Agony. Oxford, New York: Oxford University Press, 1970 [1933].

Pruis, Marja 'Het gromt en bijt op zolder. De gekooide vrouw in de literatuur.' De Groene Amsterdammer 29 juli 2000.

Punter, David, The Literature of Terror. A History of Gothic Fictions from 1765 to the Present Day. London: Longman, 1996 [1980].

Punter, David and Glennis Byron, The Gothic. Oxford etc: Blackwell Publishing, 2004.

Punter, David and Glennis Byron, 'The Uncanny'. In: Idem, The Gothic. Oxford etc.: Blackwell Publishing 2004, 20-26.

Punter, David, 'The uncanny'. In: Catherine Spooner \& Emma McEvoy, The Routledge Companion to Gothic. London \& New York etc.: Routledge 2007, 129-137.

Quincey, Thomas de, De Engelse postwagen gevolgd door Over moord beschouwd als een der schone kunsten. Vert. en van een nawoord voorzien door Frans Kellendonk. Amsterdam: Tabula, 1983.

Radcliffe, Ann, De Bouwval, of de geschiedenis van de Marquisin van Mazzini. (Magazijn van geschiedenissen, romans en verhalen, 5). Rotterdam: Meyer, 1793.

Railo, Eino, The Haunted Castle: A Study of the Elements of English Romanticism. London: Routledge, 1927.

Reve, Gerard, Lieve Jongens. Amsterdam etc.: Athenaeum, 1973. 
Reve, Gerard, Oud en eenzaam. Amsterdam/ Antwerpen: Elsevier/Manteau, 1978

Reve, Gerard, Moeder en zoon. Amsterdam/ Antwerpen: Elsevier/Manteau, 1980

Reve, Gerard, De vierde man. Amsterdam/Antwerpen: Elsevier/Manteau, 1981.

Reve, Gerard, Brieven aan geschoolde arbeiders. Utrecht etc.: Veen, 1985.

Reve, Gerard, '19 maart 1988. Aan Zijne Excellentie Mr. Drs L.C. Brinkman'. Geraadpleegd 21 november 2009 via http://www.nationaalarchief.nl/images/3_10456.pdf.

Reve, Gerard, Verzameld werk. Deel 6. Amsterdam/Antwerpen: L.J. Veen, 2001.

Richter, David, The Progress of Romance: Literary Historiography and the Gothic Novel. Columbus: Ohio State University Press, 1996.

Righart, Hans, De eindeloze jaren zestig. Geschiedenis van een generatieconflict. Amsterdam: De Arbeiderspers, 1995.

Righart, Hans, De wereldwijde jaren zestig. Bezorgd door Paul Luykx en Niek Pas. Utrecht: Instituut Geschiedenis van de Universiteit Utrecht, 2001.

Ringe, Donald A., American Gothic: imagination and reason in nineteenth-century fiction. Lexington: University Press of Kentucky, 1982.

Röling, H.Q., Gevreesde vragen: geschiedenis van de seksuele opvoeding in Nederland. Amsterdam: Amsterdam University Press, 1994.

Rooden, Peter van, Religieuze regimes. Over godsdienst en maatschappij in Nederland, 1570-1990. Amsterdam: Bert Bakker 1996.

'Roman vol geheimzinnigheid'. Amersfoortse Courant 23-08-1986.

Rosenboom, Thomas, Gewassen vlees. Amsterdam: Querido, 1994.

Rosenboom, Thomas, Vriend van verdienste. Amsterdam: Querido, 1985.

Rowe, Katherine, Dead Hands. Fictions of Agency, Renaissance to Modern. Stanford: Stanford University Press, 1999. esp. hs 3 “That Curious Engine": Action at a Distance in the Duchess of Malfi' (86-110) en hs 4 'The Beast with Five Fingers: Gothic Labor Relations in Victorian Ghost Stories' (111-160).

Ruiter, Frans, 'Verkenningen in niemandsland. Over literatuur en geschiedenis.' In: Liesbeth Korthals Altes en Dick Schram (red.), Literatuurwetenschap tussen betrokkenheid en distantie. Assen: Van Gorcum 2000, 13-29.

Ruiter, Frans en Wilbert Smulders, Literatuur en moderniteit in Nederland 1840-1990. Amsterdam, Antwerpen: Uitgeverij de Arbeiderspers, 1996.

Ruyter, Martin, 'Ik wil de volle breedte van de Nederlandse taal gebruiken'. Interview. de Volkskrant, 3 januari 1986.

Sage, Victor, Horror Fiction in the Protestant Tradition. London: MacMillan, 1988.

Sage, Victor, 'Gothic Laughter: Farce and Horror in Five Texts'. In: Allan Lloyd-Smith and Victor Sage (eds.), Gothick Origins and Innovations. Amsterdam etc.: Rodopi Press, 1994, 190-203.

Sage, Victor, 'Irish Gothic: C.R. Maturin and J.S.LeFanu'. In: David Punter (ed.), A Companion to the Gothic. Oxford: Blackwell Publishers, 2000, 81-93.

Sanders, Wim, 'Een spannend tussendoortje'. Het Parool 24 april 1981.

Sanders, Stephan, 'Spookrijder'. In: idem, Buitenwacht. Essays \& kronieken 1986-1995. Amsterdam: De Bezige Bij, 1995, 128-130.

Sanders, Stephan, 'Tegenzang'. In: idem, Buitenwacht. Essays \& kronieken 1986-1995. Amsterdam: De Bezige Bij, 1995, 131-140.

Savoy, Eric, 'Spectres of Abjection: the queer subject of James's "The Jolly Corner"'. In: Glennis Byron \& David Punter (eds.), Spectral Readings: towards a Gothic Geography. Basingstoke, Hampshire \& London: MacMillan Press, 1999, 161-177. 
Scharpé, Michiel, 'A Trail of Disorientation: Blurred Boundaries in Der Sandmann'. Image and Narrative. Online Magazine of the Visual Narrative. Issue 5 The Uncanny, January 2003. Geraadpleegd 21 november 2009 via http://www.imageandnarrative.be/uncanny/uncanny.htm

Schmitt, Cannon, Alien Nation: Nineteenth-Century Gothic Fictions and English Nationality. Philadelphia: University of Pennsylvania Press, 1997.

Schouten, Dennis, Duivelse boeken. Twee eeuwen griezelliteratuur in de Lage Landen. Den Haag: Stichting Bibliographica Neerlandica, 1997.

Schouten, Diny, 'God geeft nergens om'. Vrij Nederland, 4 november 1995.

Schouten, Rob, 'Het hachelijke van het 'Tweede Boek'. Trouw, 9 januari 1986.

Schutte, Xandra, 'Gotiek. Laat er naar adem gesnakt worden'. De Groene Amsterdammer 28-101992.

Schutte, Xandra, 'Want wat is een vrouw alleen? (Recensie van Een sterke man)'. Groene Amsterdammer 21-09-1994.

Schutte, Xandra, 'Ironie en radicalisme. Over het feminisme van Renate Dorrestein', in: Maskerade. Essays (1999), 143-161.

Schuurmans, Marlies, Gothic novel: gotische roman of huiverroman. Een onderzoek naar het voorkomen van 'gothic novels' in Nederland. Doctoraalscriptie Universiteit van Amsterdam, 1982.

Schuyt, Kees en Ed Taverne. 1950. Welvaart in zwart-wit. Den Haag: Sdu uitgevers, 2000.

Scott, Joan Wallach, 'Gender: A Useful Category of Historical Analysis'. American Historical Review, 91, No. 5 (December 1986), 1053-1075.

Scott, Joan Wallach, 'Deconstructie van gelijkheid-versus-verschil. De bruikbaarheid van de poststructuralistische theorie voor het feminisme', Jaarboek voor Vrouwengeschiedenis 10 (1989), 96-112.

Scott, Joan Wallach, Gender and the Politics of History. New York: Columbia University Press, 1999 [1988].

Sedgwick, Eve Kosofsky, Between Men. English Literature and Male Homosocial Desire. New York: Columbia University Press, 1985.

Sedgwick, Eve Kosofsky, The Coherence of Gothic Conventions. London: Methuen, 1986 [1980].

Sedgwick, Eve Kosofsky, Epistemology of the closet. Berkeley and Los Angeles: University of California Press, 1990.

Sengers, W.J., Homoseksualiteit als klacht. Een psychiatrische studie. Bussum: Paul Brand, 1969.

Shapin, Stephen \& Simon Schaffer, Leviathan and the Air-Pump: Hobbes, Boyle, and the Experimental Life. Princeton: Princeton University Press, 1985.

Shelden, Pamela J., 'Jamesian Gothicism: the Haunted Castle of the Mind'. Studies in the Literary Imagination 7 (1974), 1, 121-134.

Shelley, Mary, Frankenstein or the Modern Prometheus. In: Four Gothic Novels. Oxford: Oxford University Press, 1994, 445-606 [1818].

Showalter, Elaine, Sexual Anarchy. Gender and Culture at the Fin de Siècle. New York: Viking, 1990.

Silverman, Kaja, Male Subjectivity at the Margins. New York \& London: Routledge, 1992.

Simonis, Annette, Grenzüberschreitungen in der phantastischen Literatur. Einführung in die Theorie und Geschichte eines narrativen Genres. Heidelberg: Universitätsverlag Winter, 2005.

Sitniakowsky, Iwan, 'Gerard Reve overtreft zichzelf in de vierde man'. De Telegraaf, 10-04-1981.

Slob, Marjan, Foute fantasieën of Kleine filosofie van de ontvankelijkheid. Rotterdam: Lemniscaat, 2007.

Smit, Louis, 'Nieuwe novelle van Gerard Reve het oude liedje'. Hervormd Nederland, 2 mei 1981. 
Smith, Andrew (ed.), Gothic Modernisms. Houndmills: Palgrave, 2001.

Smith, Andrew, Victorian Demons: Medicine, Masculinity and the Gothic at the Fin de Siècle. Manchester and New York: Manchester University Press, 2004.

Smith, Andrew \& Diana Wallace, 'Introduction'. Gothic Studies 6/1 (2004), 1-7.

Smith, Andrew \& William Hughes, Empire and the Gothic: the Politics of Genre. Houndmills: Palgrave, 2003.

Smulders, Wilbert, 'Over de onmogelijkheid van Gerard Reve als kindervriend. Jeugdliteratuur is van een andere culturele orde'. Literatuur zonder leeftijd, 50 (1999), 325-342.

Snapper, Johan, De spiegel der verlossing in het werk van Gerard Reve. Utrecht/Antwerpen: Veen, 1990.

Soeteman, Gerard, De vierde man. Het Nederlands Scenario nr 6, sept. 1991. Amsterdam: International Theatre \& Film Books, 1991.

Spooner, Catherine, Contemporary Gothic. London: Reaktion Books, 2006.

Spooner, Catherine, 'Gothic in the twentieth century'. In: Catherine Spooner \& Emma McEvoy (eds.), The Routledge Companion to Gothic. London: Routledge, 2007, 38-49.

Spooner, Catherine \& Emma McEvoy (eds.), The Routledge Companion to Gothic. London: Routledge, 2007.

Steinz, Pieter, 'Door De vierde man tot Reve'. NRC Handelsblad, 16 december 2006.

Stevick, Philip, 'Frankenstein and Comedy'. In: George Levine and U.C. Knoepflmacher (eds.), The Endurance of Frankenstein: Essays on Mary Shelley's Novel. Berkeley etc: University of California Press, 1979, 221-239.

Sturkenboom, Dorothée, Spectators van Hartstocht. Sekse en emotionele cultuur in de achttiende eeuw. Hilversum: Verloren, 1998.

Stuurman, Siep, 'Tijd en ruimte in de Verlichting. De uitvinding van de filosofische geschiedenis.' In: Maria Grever en Harry Janssen, De ongrijpbare tijd. Temporaliteit en de constructie van het verleden. Hilversum: Verloren 2001, 79-96.

Stynen, Ludo, 'Een mens van goede wil: Eugeen Zetternam'. In: Koen Wauters (red.), Verhalen voor Vlaanderen. Aspecten van het Vlaamse fictionele proza tot aan de Tweede Wereldoorlog. Kapellen: Pelckmans, 1997, 50-69.

Swelheim-de Boer, Reinsk, Seksuele moeilijkheden van de vrouw: naar een bewerking van 'Sex difficulties in the wives'. S.l.: Nederlandse Vereniging voor Sexuele Hervorming, 1960.

Swinnen, Aagje, Het slot ontvlucht. De 'vrouwelijke' Bildungsroman in de Nederlandse literatuur. Amsterdam: Amsterdam University Press, 2006.

Swire, Otta F., The Inner Hebrides and their legends. University of California, 1964.

Taylor, Charles, Sources of the Self. The Making of Modern Identity. Cambridge MA: Harvard University Press, 1989.

Taylor, Charles, The Malaise of Modernity. Concord, Ontario: Anansi Press Ltd, 1991.

Tielman, Rob A.P., Homoseksualiteit in Nederland: Studie van een emancipatiebeweging. Meppel: Boom, 1982.

Tomkins, Silvan, Affect Imagery Consciousness: Vol 2. The negative affects. New York: Springer, 1963.

Tompkins, Jane, Sensational Designs. The Cultural Work of American Fiction 1790-1860. Oxford: Oxford University Press, 1985.

Vaessens, Thomas, De revanche van de roman. Literatuur, autoriteit en engagement. Nijmegen: Vantilt, 2009.

Van geval tot geval. Jaaroverzicht van Neerlands nieuws. Polygoon 1966. http://cgi.omroep.nl/cgibin/streams?/ibg/sn038009-bb.wmv?title=Jaaroverzicht\%201966. Geraadpleegd 27 januari 2010. 
Varma, Devendra P., The Gothic Flame: being a history of the Gothic novel in England: its origins, efflorescence, disintegration and residuary influences. London: Barker, 1957.

Veeder, William. Mary Shelley and Frankenstein: the Fate of Androgyny. Chicago: University of Chicago Press, 1986.

Verbij, Antoine, 'Genade. Lekker katholiek'. De Groene Amsterdammer 28-10-1992.

Verbogt, Thomas, 'Beklemmende roman Thomas Rosenboom'. Tubantia, 8 januari 1986.

Verhoeven, Paul, De vierde man. De Rob Houwer Film Collectie. [S.I.]: Indies Home Entertainment, 2005 [1983].

Verhoeven, W.M., 'Opening the Text: the Locked-Trunk Motif in Late Eigtheenth Century British and American Gothic Fiction. In: Valeria Tinkler-Villani e.a. (eds.), Exhibited by Candlelight. Sources and Developments in the Gothic Tradition. Amsterdam, Atlanta: Rodopi, 1995, 205-221.

Verschoore, N., 'Gerard Reve in een ander register en toch waarlijk zichzelf. Laatste Nieuws 24 mei 1981.

Verstappen, J., 'Ironische thriller “De vierde man”, , Het Binnenhof 18 april 1981.

Verstraten, Ronald, 'Vlissingse kapster onthult, maar laat mysterie intact . . . 'De Stem 17 mei 1996.

Vervaeck, Bart, Het postmodernisme in de Nederlandse en Vlaamse roman. Brussel, Nijmegen: VUBPress, VanTilt, 2004 [1999].

Vervaeck, Bart, 'Ziek van mystiek. Woord en vlees bij Frans Kellendonk'. Dietsche Warande en Belfort 138 (1993), 349-358.

Vincent, Sybil Korff, 'The Mirror and the Cameo: Margaret Atwood's Comic/Gothic Novel'. In Juliann Fleenor (ed.), The Female Gothic. Montreal: Eden Press, 1983, 153-163.

Vooren, Rob, 'De Vierde Man: Heerlijke ruiker tussen kunstblommen'. Leidsch Dagblad 28-081981.

Walker, Richard J., 'Blooming Corpses. Burying the Literary Corpus in the Modern City'. Gothic Studies 4/1 (May 2002), 1-13.

Walpole, Horace, The Castle of Otranto. In: Four Gothic Novels. Oxford: Oxford University Press, 1994, 1-81.

Warmerdam, Hans en Pieter Koenders. Cultuur en ontspanning. Het COC 1946-1966. Amsterdam: N.V.I.H. COC / Rijksuniversiteit Utrecht, 1987.

Warren, Hans, 'Letter en geest, spookverhaal.' PZC 3 april 1982.

Warren, Hans, 'Vriend van verdienste: Thomas Rosenboom'. PZC, 25 januari 1986.

Warren, Hans, 'De boze boodschap'. PZC 28 januari 1989.

Warren, Hans (1989a), 'Ongewenst onderdak'. [Recensie van Vincent Mahieu, Schuilen voor de regen], PZC 10 juni 1989.

Warwick, Alexandra, 'Feeling gothicky?' Gothic Studies 9/1 (May 2007), 5-15.

Watt, Ian, The Rise of the Novel. Studies in Defoe, Richardson and Fielding. University of California Press, 2001 [1957].

Waugh, Patricia, Metafiction. The theory and practice of self-conscious fiction. Londen: Methuen, 1984.

Webeling, Pieter, 'Ik ben een kopje kleiner gemaakt'. Interview met Renate Dorrestein. Volkskrant Magazine 21 juli 2001, 9-13.

Weegh, Arne op de, 'Een alternatief spookverhaal. Postmoderne kenmerken in Kellendonks Letter en Geest.' Nederlandse letterkunde 10 (2005) 3 (sep), 234-252.

Weijers, Ido, Terug naar het behouden huis. Romanschrijvers en wetenschappers in de jaren vijftig. Amsterdam: SUA,1991. 
Weisgerber, Jean, Aspecten van de Vlaamse roman, 1927-1960. (vierde druk). Amsterdam: Athenaeum - Polak \& Van Gennep, 1976.

Wesseling, E., Writing History as a Prophet. Postmodernist Innovations of the Historical Novel. Amsterdam/Philadelphia: John Benjamins Publishing Company, 1991.

West, Russell, and Frank Lay (eds.), Subverting Masculinity: Hegemonic and Alternative Versions of Masculinity in Contemporary Culture. Amsterdam: Rodopi, 2000.

Wester, Rudi, 'Als ik een man was, was ik vast een etter. Renate Dorrestein over haar nieuwe boek.' Interview. Opzij. November 1988, 14-17.

Westerman Holstijn, A.J., Seksualiteit van de volwassen vrouw. 's-Gravenhage: NVSH, 1968.

Williams, Ann, Art of Darkness. A Poetics of Gothic. Chicago: University of Chicago Press, 1995.

Winnett, Susan, 'Coming Unstrung: Women, Men, Narratives and Principles of Pleasure. PMLA 105 (3) May, 505-518.

Wolff, Cynthia. 'The Radcliffean Gothic Model: a form for feminine sexuality.' Modern Language Studies 9 (3) (Autumn 1979) 98-113.

Wolfreys, Julian, “I wants to make your flesh creep”. Dickens and the Comic Gothic'. In: idem, Victorian Hauntings: Spectrality, the Uncanny and Literature. London: Palgrave, 2002, 2553.

Wright, Angela, Gothic Fiction. A Reader's Guide to Essential Criticism. Houndmills, Basingstoke etc.: Palgrave Macmillan, 2007.

Zuidinga, Robert-Henk, Uit den boze. Oorspronkelijke griezelverhalen. Amsterdam: Sijthoff, 1984.

Zuidinga, Robert-Henk, Boosaardig. Oorspronkelijke griezelverhalen. Amsterdam: Sijthoff, 1986. 



\section{SUMMARY \\ Gothic Appearances in Dutch novels 1980-1995}

The main question this dissertation wants to answer is: what does gothic do in late-twentieth century Dutch novels? It is in fact a twofold question: firstly, what are the effects of the gothic in literary terms? I analyse how the gothic makes its appearance in six Dutch novels from the period 1980-1995: Frans Kellendonk's Letter en Geest (Letter and Ghost, 1982); Gerard Reve's De vierde man (The Fourth Man, 1981); Thomas Rosenboom's Vriend van verdienste (Friend of Honour, 1985); Renate Dorrestein's Noorderzon (Moonlight Flit, 1986) and Het perpetuum mobile van de liefde (The Perpetuum Mobile Machine of Love, 1988) and Vonne van der Meer's Spookliefde (Ghost Love, 1995). By analysing these novels in detail, I explore the potential of a gothic frame of interpretation, which is a relatively new approach in Dutch literary criticism. Each chapter contains an analysis of the way in which elements from the $18^{\text {th }}$ and $19^{\text {th }}$ century gothic tradition create literary effects in these six novels. Although none are considered classic gothic or horror stories à la Bram Stoker or Stephen King, gothic elements appear in all of them: a locked room in the attic, a ghostly apparition in the library, crows in a graveyard, corrupt monks on a remote island, a metamorphosis into a vampire and so on.

My close readings of these six novels serve to answer my second question: what is the gothic doing there and then, at that time, in that place, or, in other words, what kind of cultural work is being done by the gothic in these novels? In this dissertation the gothic is taken to be a cultural strategy to stage the ambivalences which are caused by modernisation processes. These are ambivalences produced by a perceived breach between present and past. When things are labelled as gothic, an opposition between a (modern) present and a traditional (gothic) past is staged - whether by Italian Renaissance humanists, who called the medieval cathedrals 'gothic', or by present-day 'goths' who self-consciously want to distance themselves from modern life. Thus, the dynamic of progression and lagging behind - in other words, of modernisation - is crucial to the gothic. Every period has its own gothic past; the contrast between a modern present and an archaic past can, and is being staged time and again, with differ- 
ent accents for different periods and aspects of modernisation. I understand the gothic as a resilient cultural strategy for the representation of conflicts of modernisation; the gothic, as a form of excess, stages the tensions that modern society is unable to deal with.

The novels studied in this dissertation were all published after the 'sixties', a period of modernisation which greatly influenced The Netherlands in many ways. A remarkable aspect of that modernisation, as the historian James Kennedy (1995) has noted, was the dominance of a 'rhetorics of progression', which caused social changes to happen smoothly and swiftly. The Netherlands became an icon of sexual liberation, women's emancipation and individualisation. One could wonder what cultural conflicts the gothic still has to rework in a society that has experienced such a smooth transition to emancipation. The analysis of my case studies, however, shows that the gothic still has its work cut out for it.

In chapter 1 I outline my perspective on the gothic, as discussed above, and also present an overview of historical meanings of the term 'gothic' in Britain and The Netherlands, and of the history of gothic literature in The Netherlands.

Chapter 2 contains an examination of Frans Kellendonk's Letter en Geest (Letter and Ghost, 1982). I argue that this novel represents a friction between old and new articulations of homosexual identity through the gothic. Letter en Geest shows the tensions between private life and public life, which are expressed in the blurring discourses of sexuality and of working life. The source of these tensions is what Eve Sedgwick has called male homosexual panic: the fear of being perverted. I suggest that it is the specific modern, that is late twentiethcentury, form of homosexual identity and the way it is acquired which accounts for the gothicism in Letter en Geest. Kellendonk rewrites the classic ghost story and critically comments on the effects of sexual emancipation, two issues which are related in this novel. While the classic ghost story derives its narrative tension from an 'existential problem' (does the ghost exist?), the male protagonist in Letter en Geest immediately solves the problem of having seen a ghost in the library by bending the rules of what counts as knowledge to his will, thus foregrounding the "problem of knowledge". This is analogous to the effect of the modern coming-out strategy for homosexuals: knowledge (knowing and being known) precedes being (homosexual).

Sexual liberation has undoubtedly increased the freedom for homosexuals to "come out of the closet". But Letter en Geest shows a possible drawback to this emancipation. When being (existing as a homosexual) is dependent on knowing - either through making yourself known, or through being recognized 
(known) by others-, sexual identity becomes less a matter of private choice. It is an identity that has to be claimed and performed in public. In Letter en Geest Kellendonk uses gothic strategies for an apt representation of the potential panic that accompanies this necessity to claim a sexual identity. Kellendonk presents a character who struggles with the modern demand to claim a sexual identity or else not to be.

The novel I analyse in chapter 3 is the comic gothic De vierde man (The Fourth Man, 1981) by Gerard Reve. De vierde man is clearly inspired by the gothic novel, but it gives gothic conventions a comic turn. I argue that Reve uses the gothic as a suitable cultural strategy to represent the fragility of the achievements of the sexual revolution of the late sixties and seventies. In this novel women's sexual pleasure, i.e. sexual autonomy, is portrayed as gothic, as a threat to traditional masculinity. Using Judith Butler's work on the performativity of gender, I examine the protagonist's parodies of heterosexual masculinity. I interpret them both as parodies of gender - the faggot who plays a man, in his own words -, and as parodies of sexuality - the homosexual who plays the heterosexual. Depending on the perspective one takes, these parodies may be read as a critique or a confirmation of the heterosexual romance plot. The position of the male protagonist is ambivalent: on the one hand, he connects gender and sexuality in a hetero normative way. On the other hand, he undermines the notion of naturalness and authenticity because of his successful parody of a heterosexual.

The subversion of authenticity in De vierde man concentrates on sexual identity, which is often considered the core of one's self. In the case of Gerard Reve, it is also the core of his authorship. Using Peter Brooks' theory of narrativity and sexuality, I analyse the connection between sexuality and authorship in De vierde man. The novel asks the questions 'what is a man?' and 'what is a story?'. Both questions are answered through an opposition of hetero- and homosexuality. Heterosexuality and the romantic plot are (still) closely related, I conclude, although Reve effectively exposes the seeming naturalness of the romantic plot.

The fourth chapter presents an analysis of the novel Vriend van verdienste (Friend of Honour, 1985) by Thomas Rosenboom. The motifs of the gothic mansion, with a locked room and a mad woman in the attic, are reworked in this novel, which is set in a seemingly archaic past, on the threshold of the 1960s. The novel's main sources of gothic tension are class and masculinity. The suggestion of a possible class mobility is violently suppressed in this novel. 
Excessive violence is released when the main protagonist literally crosses boundaries by locking himself up in the gothic mansion of the rich boys he wants to befriend. I analyse the rivalry between the four protagonists with the help of Eve Sedgwick's work onhomosocial bonds. The boys are engaged in a power struggle for male dominance. Both the privileged position of the higher class and the values of the self-employed class - in this case servitude as a matter of honour - are put under pressure. The tensions between dependence and independence, between power and powerlessness are central to this novel. The gothic stages the blurring of boundaries in terms of purity and the abject. The main character - the least masculine of the boys, in terms of age and class becomes abject. Paradoxically, in this position he is able to subvert the social order most effectively.

Chapter 5 presents an analysis of two novels by the 'queen of Dutch gothic literature', Renate Dorrestein. I read her Noorderzon (Moonlight Flit, 1986) and Het perpetuum mobile van de liefde (The Perpetual Mobile Machine of Love, 1988) against the background of the lively international feminist debate on female gothic, in which terms Dorrestein's work has mainly been analyzed so far. This 'female gothic' frame of interpretation interprets gothic first and foremost as a quest for female autonomy. Using Nancy Armstrong's work on the gothic as an alternative way of imagining a community, I present a new way of interpreting the gothic in these two novels by Dorrestein. I argue that the gothic serves to show the limitations of individual agency, and not specifically female agency.

In Noorderzon, an ethical world view of the honest life is confronted with metaphysical Evil. Thus, this gothic novel shows that moral virtue cannot prevent evil from happening. The power of the narrator/writer is not strong enough to avert evil. I examine cross-connections between second wave feminist discourse and gothic narrative strategies, in particular the metaphor of the female voice. The professional voice of the protagonist, who is a producer of radio plays, leads to ambiguity between professional narration and personal report, between reality and fiction. My investigation of the novel shows that this blurring of borders causes gothic excess.

In my reading of Het perpetuum mobile van de liefde I discuss a case of gothic monstrosity that turns upon feminism itself: the novel shows (feminist) sisterhood as monstrous, and artistic failure as liberating. The Perpetuum Mobile of Love explores what happens when the monster shows an uncanny similarity between Self and Other, rather than a marked difference. Both in the narrator Renate's dual relation with her dead sister, who casts her vampiric shadow over 
her work, and with the fictional character Godelieve - her 'monster of Frankenstein' - it is identification rather than difference, which is the source of gothic monstrosity. I argue that Dorrestein investigates the feminist notion of sisterhood through the autobiographical narrative about her sister's suicide and the fictional story about Godelieve, thereby showing feminism to be a multifaceted enterprise. Dorrestein finds modes to express the unspeakable rivalry and competition between sisters - and that includes feminists. The vampiric collective of sisters emerges as a serious threat to the female individual.

The sixth chapter focuses on a novella by Vonne van der Meer, Spookliefde (Ghost Love, 1995). In this text the gothic serves to represent issues of (female) sexual desire as friction between tradition and modernisation. The recognition of female sexual autonomy is a relatively recent phenomenon. This novel deals, via the gothic, with the friction between determinacy and surrender: how do the two relate? Desire may be dangerous, and cannot be pursued without loss. The many gothic repetitions and doublings in the novel form a counterweight to notions of linearity and progression, and show the ambiguity of modernisation and the modern subject's doubts. Future generations of young women will be haunted by the fear of not becoming sexually active, of not finding romantic love. In the midst of all repetitions, it is notable that the non-repeatable does not happen in this story: the first time, the loss of virginity. The analysis of anachronism in Spookliefde shows the potential connections between historical context and modernisation processes. The remote and archaic Irish island forms a meaningful gothic setting for this story, in which the protagonist develops a catholic sensitivity. Spookliefde thereby defies the idea that modernisation leads to secularisation.

In chapter 7, I conclude that the gothic is alive and well in Dutch literature; these six novels employ it in a great variety of ways. The first advantage of a gothic frame of interpretation is that it connects these particular authors for the first time. Moreover, reading gothic also makes it possible to study Dutch literature in an international context. Until now Dutch authors have often been studied in isolation or are only compared to each other. But of course literature has become more than a national enterprise. Reading gothic offers new views on international influences, kinships, and traditions. Finally, reading gothic is a plea for interpretation, or as Brewster (2000) claims: 'reading gothic makes you see things'.

As far as my second research question is concerned - the cultural work gothic does - I conclude that in all novels under discussion the gothic is a way 
of staging ambivalences about the achievements of the 1960s. My analysis focuses on issues of gender and sexual emancipation, which include new ways of defining masculinity and femininity, sexual equality, sexual autonomy of women and gay emancipation. The ambivalences about modern achievements operate on two levels in these novels. Firstly, they contain ambivalences about the dominance of new power relations: how firmly rooted are these new values? Have the old values really disappeared? In Vriend van verdienste class mobility leads to a violent struggle. Topaas in Noorderzon and Renate in Perpetuum mobile have to fight for their independence. The second level of ambivalence refers to the value of those new relations: is the new really better than the old? The protagonists of Letter en Geest, and Spookliefde seem to doubt it. The two levels are sometimes inseparable: in De vierde man the protagonist tests the dominance of the new power relations through parody, but in the meantime he prefers 'old fashioned' masculinity.

My interpretations have brought to the fore two remarkable correspondences between the six novels. Firstly, all novels relate in some way or another to Catholicism. I make a distinction between the function of Catholicism in these Dutch novels and in classic British gothic novels. In the latter, strong anticatholic sentiments helped shape certain concepts of British national identity. In these twentieth-century Dutch gothic novels, Catholicism appears to be a suitable vehicle for the expression of desires of fulfilment and salvation. In these texts, secularisation is not the self-evident outcome of modernity.

The second remarkable correspondence between the novels is that they question the capability of their protagonists to truly lead their own life. I interpret the abundance of the gothic Doppelgänger and stand-ins in these novels in terms of the appeal to fulfil oneself and be an authentic individual. The philosopher Charles Taylor has called this ethics of authenticity a typically modern phenomenon.

These gothic novels show the insecurity of individuals as to who they can be in times of historical change. When meanings of gender and sexuality change, articulations of the self change as well. Manifesting oneself as 'modern' entails choices that vary historically, i.e. after the sixties these choices have changed considerably. The protagonists of the six novels all feel the appeal of being modern individuals, but do not know how to respond to that appeal. What does it mean to be a man (Reve, Rosenboom), a bachelor (Kellendonk), a homosexual (Reve en Kellendonk), a woman (Van der Meer), a feminist (Dorrestein), a friend (Rosenboom)? In the new societal relations the answer to those questions is not clear at all - and at that point the gothic appears. 


\section{NAMENREGISTER}

Aalten, Thomas van, 217

Acton, William, 192

Adler, Otto, 192

Adriaan, Michiel, 23

Alighieri, Dante, 18, 160

Alphen, Ernst van, 6, 9, 42, 45, 128, 129

Amsberg, Ariane, 192

Amsberg, Claus von, 109, 110

Anbeek, Ton, 11

Andeweg, Agnes, 11, 29, 35, 67, 103, 170

Andeweg, Janny, 175

Anker, Robert, 185

Armstrong, Nancy, 11, 142, 143, 144, $145,146,150,151,156,157,163$, $164,166,168,171,172,173,174$, 175,177

Atwood, Margaret, 14, 80, 125

Austen, Jane, 78, 104

Aydemir, Murat, 99

Ayers, Mary, 157

Baalen, Anneke van, 167, 175

Backus, Margot Gayle, 185

Bakhuizen van den Brink, R.C., 25

Baldick, Chris, 32, 183, 184, 185, 186, 189, 191, 193, 201, 202

Banks, Iain, 80

Banville, John, 14, 185

Bartels, Thijs, 41

Bastiaans, W., 218

Bax, Sander, 35, 45

Beach Boys, The, 109

Beatles, The, 109

Beatrix, Prinses, 109, 110
Becker, J.W., 187

Becker, Susanne, 30

Beckford, William, 13, 24

Beekman, Klaus, 70, 71, 73, 93

Beer, E.S. de, 16, 17, 18

Beerman, K., 132

Beets, Nicolaas, 23

Belcampo, 27, 218

Belenky, Mary Field, 166

Berg, Willem van den, 24

Berge, H.C. ten, 218

Berger, Peter L., 187

Bervoets, Jan, 23

Bie, Wim de, 216

Bijte, Ton, 5, 6

Bilderdijk, Willem, 19

Billiani, Francesca, 32

Birney, Alfred, 218

Blaas, P.B.M., 20, 202

Blaman, Anna, 10, 68, 72

Blink, Inge van den, 172

Boelaars, Bert, 93

Boon, Tijn, 40, 41, 42

Bordewijk, F., 27, 36, 40, 218

Bosboom, Rolf, 40

Botting, Fred, 49, 72, 107, 146, 196, 213

Bourke, Joanna, 32, 78

Bousset, Hugo, 119

Bouw, Marjan de, 172

Boven, Erica van, 33

Brabon, Benjamin, 29

Braches, Ernst, 36

Braidotti, Rosi, 29 
Brakel, L.J. van, 45

Brakman, Willem, 5, 6, 7, 14, 31, 32

Brannigan, John, 10

Breedt Bruyn, Martje, 151, 172

Brems, Hugo, 9, 10, 213, 217

Brewster, Scott, 5, 180, 211

Bridgwater, Patrick, 35

Briggs, Julia, 37, 44, 46, 47

Brijs, Stefan, 217, 218

Brill, Alida, 167

Brink, J.T. van den, 45

Brinkman, E., 70

Brinks, Ellen, 30

Brockden Brown, Charles, 25

Bronfen, Elisabeth, 30, 74, 77

Brongersma, E., 132

Brontë, Charlotte, 14, 135

Brooks, Peter, 98, 99, 100, 101

Bruhm, Steven, 14, 129, 130

Bueler, Lois, 29

Buijnsters, P., 24

Buikema, Rosemarie, 7, 8, 11, 12, 21, 26, 27, 29, 71, 72, 73, 91, 104, 140, 141, 181

Buisman, J. Fzn., 24

Buren Schele, A.D. van, 23

Burke, Edmund, 198

Burroughs, William S., 156, 161

Butler, Judith, 82, 83, 84, 85, 94

Butterfield, Herbert, 20

Byron, Glennis, 17, 104, 158

Campen, Jacob van, 19

Carmiggelt, Simon, 92

Carter, Angela, 14, 80, 140

Castle, Terry, 30

Cavell, Stanley, 159

Chabot, Sean, 60, 61

Chatterton, Thomas, 37

Chaucer, Geofffrey, 18

Claus, Hugo, 68, 217, 218

Clery, E.J., 14, 17, 18, 29, 30, 80, 107, 198

Collins, Wilkie, 29

Coornhert, Dirck, 111

Corporaal, Marguérite, 98

Coster, Saskia de, 217, 218

Costera Meijer, Irene, 167, 168, 171, 172

Couperus, Louis, 11
Cox, Jeffrey, 15

Cremer, Jan, 10

Culler, Jonathan, 203

Currie, Mark, 94

Daenen, M., 11

Daisne, Johan, 218

Dautzenberg, J.A., 11

Day, William Patrick, 14

Deken, Aagje, 24

DeLamotte, Eugenia C., 29

Dentith, Simon, 79, 80, 82

Derks, Will, 92, 95, 97

Dever, Carolyn, 134

Dewaide, Philomene, 40

Dickens, Charles, 14, 29

Diderot, Dennis, 24

Diepenhorst, Isaac Arend, 109

Dierickx, Arno, 108

Dijk-Hemmes, Fokkelien van, 166

Dijkhuis, J.L., 95

Dijkstra, Bram, 30, 73, 192

Doorman, Maarten, 31, 197

Dorrestein, Renate, 7, 11, 27, 31, 139, $140,141,142,145,147,151,163$, $164,167,168,169,171,172,177$, 179, 180, 185, 211, 212, 216, 218

Douglas, Alfred, 36, 56

Douglas, Mary, 117

Ducray-Duminil, François, 24

Dullaart, Leo, 61

Dunk, H.W. von der, 21, 107, 109

Duyvendak, Jan Willem, 22, 60, 61

Dyer, Richard, 62, 63, 130

Eck, Mieske van, 172

Effen, Justus van, 18

Ejlersen, Mette, 90

Ekelschot, Marijke, 175

Elferen, Isabella van, 63

Elias, Norbert, 112

Eliot, George, 49

Eliot, T.S., 14

Ellis, Albert, 90

Ellis, Kate Ferguson, 29, 104

Eugelink, Liesbeth, 188

Fabricius, Johan, 108, 109, 132

Feith, Rheinvis, 24

Felman, Shoshana, 36, 205

Ferron, Louis, 217 
Fisher, Jerilyn, 167

Fitzgerald, Lauren, 28

Flammang, Janet A., 167

Flavius Josephus, 109

Fleenor, Julian, 29

Fletcher, Peter, 192

Foucault, Michel, 73

Fowler, Alastair, 15

Frank, Adam, 159, 160, 170

Franke, Herman, 11, 27

Frankiel, Tamar, 167

Freud, Sigmund, 91, 99, 158, 159, 169

Fritzsche, Peter, 20, 63

Fuchs, Barbara, 15

Gaigher, Louis, 11, 140, 141

Gamer, Michael, 13, 15, 29

Garber, Marjorie, 55

Gard, Roger, 25

Garlick, S., 90

Gay, Peter, 192

Geeraerts, Jef, 218

Geest, Joost de, 11

Genz, Stephanie, 29

Gilbert, Sandra, 78, 144

Gilligan, Carol, 143

Girard, René, 124

Goddu, Teresa A., 49

Goedegebuure, Jaap, 35, 40, 41, 42, 43, $45,58,103,104,185,186,188$

Goedkoop, Hans, 41, 42, 217

Goethe, Johann Wolfgang von, 18

Gorp, Hendrik van, 11, 15, 18, 23, 24, 25, 26

Gray, Thomas, 37

Grunenberg, Christoph, 16

Gubar, Susan, 78, 144

Haakman, Anton, 217, 218

Haasse, Hella, 11, 27, 68, 139, 140, 141, $145,146,149,150,168,181$

Hafkamp, Hans, 95

Haggerty, George E., 30, 125

Halberstam, Judith, 14, 15

Hall, D., 32

Hall, Gijsbert van, 110

Halsema, Annemie, 82, 83

Hamelink, Jacques, 218

Haraway, Donna, 47, 48, 145
Hart, Maarten 't, 10, 11, 32, 139, 141, 151, 172, 188, 217

Haslam, Richard, 185

Hawthorne, Nathaniel, 25, 104

Hayles, Katherine, 152, 156, 161

Hazeu, W., 68

Heijden, A.F.Th. van der, 188

Heijne, Bas, 218

Heijst, Annelies van, 141, 164, 165, 166, 168, 177

Heiland, Donna, 29

Hekma, Gert, 60, 95

Heller, Tamar, 29

Hemmerechts, Kristien, 218

Hendershot, Cyndy, 30, 49, 91

Herder, J.G., 73

Herman, Luc, 155

Hermans, Mariëtte, 185

Hermans, W.F., 10, 11, 27, 62, 68, 72

Heumakers, Arnold, 43, 68

Heyward, Carter, 167

Hilberts, Ina, 11

Hillis Miller, J., 205

Hirsch, Marianne, 99

Hite, Shere, 192

Hobsbawm, Eric, 17

Hodkinson, Paul, 16

Hoekstra, Hanneke, 11, 29

Hoeveler, Diane Long, 29

Hoffmann, E.T.A., 159

Hogg, James, 125

Hogle, Jerrold, 78

Holbrook, Wm. C., 17

Holland, Norman, 18, 29

Homeros, 200

Hoof, Aafke van, 169

Hoop Jr, Adriaan van der, 23

Horner, Avril, 29, 32, 49, 78, 79, 80, 81, $87,88,92,123$

Houston, Gail Turley, 14

Howard, Jacqueline, 78

Hughes, William, 14, 30, 97

Hugo, Victor, 23

Huisman, Marijke, 177

Hume, Robert, 14

Hurley, Kelly, 149

Hutcheon, Linda, 64, 78, 79

Huygens, Constantijn, 18, 19 
James, Henry, 25, 35, 36, 49, 71, 205

Jameson, Fredric, 79

Jansen, Yves, 108

Jentsch, Ernst, 158, 159

Johnson, Claudia, 78

Jong, Oek de, 35, 188, 217

Jonge, A.Th.M. de, 11

Jongstra, Atte, 217

Juliana, Koningin, 110

Jünger, Ernst, 104

Kaare, P., 90

Kafka, Franz, 104

Kagie, R., 141

Kahane, Claire, 29, 166

Kanter, Rosabeth Moss, 167

Kaplan, Stephen, 164

Karloff, Boris, 5

Kellendonk, Frans, 7, 11, 31, 35, 36, 37, $38,39,40,41,42,43,45,47,55,61$, 62, 188, 210, 211, 216, 217

Kempen, Yves van, 218

Kemperink, Mary, 8

Kennedy, James, 21, 22, 60, 91, 107, 137, 187, 210

Kermode, Frank, 203

Kerr, Carmen, 90

Kesteren, Ronald van, 31

Keulen, Mensje van, 217, 218

Kilfeather, Siobhán, 185

Killeen, Jarlath, 185

King, Stephen, 7, 14

Kinsey, Alfred, 192

Klein, Marian van der, 9, 132, 167

Klein, Naomi, 143

Kliger, Samuel, 17

Kloek, Joost, 23, 24, 26

Knap, Henri, 68

Kneppelhout, Jan, 23

Koenders, Pieter, 132

Koenis, Sjaak, 22, 187

Kooijmans, Luuc, 111

Kooiman, Dirk Ayelt, 35

Koolhaas, Anton, 217

Kooten, Kees van, 216

Kooy, G.A., 192

Koselleck, Reinhart, 20

Kossmann, Alfred, 68, 69

Kotzebue, A. von, 24
Kourany, Janet A., 167

Krabbé, Jeroen, 93

Krabbendam, J., 23

Kralt, P., 40, 41, 58

Krevelen, Laurens van, 36

Kristeva, Julia, 107, 117, 121, 122, 123, 135

Kuiper, Anne, 11, 29, 218

Kuipers, Willem, 68

Kunst, J.C.W., 11

Kwarto, Octavius, 24

Labrie, Arnold, 117, 118

Lamothe, E.L. de, 24

Lampo, Hubert, 69

Lang, Kathrin, 104, 157

Laqueur, Thomas, 192

Lay, Frank, 112

Leerssen, Joep, 18, 184

Leeuwen, Evert van, 21

LeFanu, J.S., 29, 185

Lehár, Franz, 77

Lennep, Jacob van, 23

Lévi-Strauss, Claude, 124

Lévy, Bernard-Henri, 117

Lewis, Matthew, 13, 24, 54, 73, 183, 191

Lewis, Paul, 78

Ligtenberg, Lucas, 92

Linders-Nouwens, Joke, 172

Linmans, Janus, 39, 40, 41, 44, 47, 55

Lloyd-Smith, Allan, 15

Locke, John, 171

Lodewijks, Jaap, 183

Loggem, Manuel van, 108

Longueil, Alfred E., 17

Loo, Vilan van de, 167

Loon, Paul van, 218

Lovecraft, H.P., 21

Lowenthal, David, 17, 20, 63, 202

Lukács, Georg, 142

Luykx, Paul, 107, 109

Maas, Nop, 93

Madoff, Mark S., 105

Maes, Kristel, 11

Mahieu, Vincent, 218

Mak, Geertje, 27

Marcuse, Herbert, 142

Marissing, Lidy van, 217

Marsh, George P., 17 
Martelaere, Patricia de, 218

Mason, William, 37

Masschelein, Anneleen, 12, 158

Mathijsen, Marita, 23, 37

Matsier, Nicolaas, 35

Matthijsse, André, 109

Maturin, Charles, 14, 37, 54, 104, 125, 185

Maurier, Daphne du, 29

Maurier, George du, 49

Mayo, Robert D., 13

McCarthy, Mary, 18

McCormack, W.J., 185

McEvoy, Emma, 16

McEwan, Ian, 129

McGrath, Patrick, 80

McHale, Brian, 45

Medeiros-Lichem, María Teresa, 167

Meer, Theo van der, 124

Meer, Vonne van der, 7, 31, 179, 180, $183,184,185,186,188,207,210$, 211, 212, 215, 216

Meeuse, Piet, 31

Meijer, Hendrik Arnold, 23

Meijer, Maaike, 9, 31, 32, 109, 167, 195

Meijer, Mia, 73

Meijsing, Doeschka, 35

Mendelssohn, Felix, 156

Mertens, Anthony, 108, 218

Meulenbelt, Anja, 167, 192

Michaelis, Hanny, 82

Mighall, Robert, 5, 19, 20, 21, 27, 32, 38, 107, 147, 181, 183, 184, 185, 186, 189, 191, 192, 193, 201, 202, 211

Mijnhardt, W.W., 24, 26

Milbank, Alison, 29

Miles, Robert, 14, 17, 29, 80, 107, 184, 198, 214

Miller, Carolyn R., 15

Miller, William, 107

Millman, Marcia, 167

Modleski, Tania, 29

Moerbeek, Toine, 92

Moers, Ellen, 28, 29, 141, 144, 171

Molhuysen, P.C., 39

Monléon, Jose B., 15

Montaigne, Michel de, 111

Moor, Wam de, 141
Moore, Barrington, 117

Morgan, Robin, 175

Möring, Marcel, 217

Morriën, Adriaan, 103

Morrison, Toni, 14

Mulder, Hanneke, 94

Mulder, Reinjan, 11, 42, 67, 68, 69

Mulisch, Harry, 10, 68

Musa, Mark, 160

Musil, Robert, 104

Mussell, Kay, 29

Naubert, Christiane, 24

Newman, Randy, 209

Niemeijer, J.C., 11

Nijgh, Lennart, 108

Nuis, Aad, 103, 108

Oakes, Davis A., 104

Oever, Annie van den, 149

Oever, Roel van den, 63, 130

Opmeer, Annemarie, 141

Oppelaar, Wim, 11, 40, 41, 43, 58

Osstyn, Karel, 68, 169

Otten, Willem Jan, 188

Otto, Rudolf, 92, 96

Oudshoorn, J. van, 103

Ouwens, Kees, 217

Overstijns, Jeroen, 218

Palmer, Paulina, 30

Pam, Max, 188

Pattynama, Pamela, 133

Paulson, Ronald, 15

Peacock, Thomas Love, 104

Peake, Mervyn, 104

Peeren, Esther, 135

Perkins Gilman, Charlotte, 170

Pieters, Jürgen, 8

Piryns, Piet, 217

Platzner, Robert, 14

Poe, Edgar Allan, 25, 104, 218

Poecke, Luc van, 11

Polak, Johan, 92, 99

Popper, Karl, 45

Portnoy, Ethel, 218

Postma, Dirk Willem, 62

Potgieter, E.J., 24, 25

Praamstra, Olf, 33

Praz, Mario, 73, 95, 218

Pruis, Marja, 139, 144 
Punter, David, 16, 17, 32, 78, 104, 158

Quincey, Thomas de, 35

Quinlan, Susan Canty, 167

Radcliffe, Ann, 14, 20, 24, 25, 28, 29, 37, 46, 104, 140, 147, 148, 183, 191

Raes, Hugo, 10

Railo, Eino, 104

Reeve, Clara, 24

Regnault Warin, J.J., 24

Rennes, Isaac van, 23

Reve, Gerard, 7, 10, 11, 21, 27, 31, 62, 67, $68,69,70,71,72,73,74,79,82,89$, 91, 92, 93, 94, 95, 96, 97, 99, 100, 101, 108, 188, 211, 212, 216

Rice, Anne, 14

Richter, David, 15

Riffaterre, Michael, 195

Righart, Hans, 22, 107, 110

Ringe, Donald, 14

Roland Holst, Henriëtte, 175

Röling, H.Q., 90

Rolling Stones, The, 109

Rooden, Peter van, 187

Rosenboom, Thomas, 7, 31, 103, 104, $105,108,109,110,119,134,210$, 216, 217

Rousseau, Jean Jacques, 73, 216

Rowe, Katherine, 53

Rowley, 37

Rubens, Peter Paul, 18

Ruebsamen, Helga, 11, 27

Rühle-Gerstel, Alice, 192

Ruiter, Frans, 9, 10, 72, 79, 107, 187, 188

Ruskin, John, 36

Ruyslinck, Ward, 218

Ruyter, Martin, 108

Sade, D.A.F. de, 119, 150

Sage, Victor, 15, 78, 184, 185, 214

Sanders, Stephan, 61, 62

Sanders, Wim, 68

Savoy, Eric, 49

Schaffer, Simon, 47

Scharpé, Michiel, 159

Schendel, Arthur van, 108

Schiller, Friedrich, 24

Schmitt, Canon, 35

Schouten, Dennis, 7, 11, 23, 24, 27

Schouten, Diny, 185, 191
Schouten, Rob, 109

Schutte, Xandra, 139, 141

Schuurmans, Marlies, 11

Schuyt, Kees, 107, 109

Scott, Joan Wallach, 144

Scribianius, C., 18

Sedgwick, Eve Kosofsky, 30, 32, 35, 38, $48,49,50,55,56,58,59,60,78,81$, $91,93,94,107,123,124,125,127$, $128,132,136$

Sengers, W.J., 60, 61

Shapin, Stephen, 47

Shelden, Pamela J., 104

Shelley, Mary, 5, 6, 14, 24

Sherman, Leona F., 29

Showalter, Elaine, 30

Silber, Ellen S., 167

Silverman, Kaja, 129, 130

Simonis, Annette, 32

Sinfield, Alan, 21

Singeling, C.B.F., 26

Sitniakowsky, Ivan, 68, 69

Slob, Marjan, 196, 197, 198

Slot, Pim, 107, 109

Smaele, Henk de, 192

Smit, Louis, 68

Smith, Andrew, 29, 30, 97

Smith, Charlotte, 24

Smulders, Wilbert, 9, 10, 72, 79, 107, 187, 188

Snapper, Johan, 95, 96

Soeteman, Gerard, 71, 93

Solomon, Martha M., 167

Soulié, Frederic, 25

Spaink, Karin, 218

Spiess, C.H., 24

Spooner, Catherine, 16, 21, 149, 180

Steinz, Pieter, 32, 68, 139

Stevenson, Robert, 49, 218

Stevick, Philip, 78

Stipriaan, René van, 92

Stoker, Bram, 7, 14, 129, 144, 185

Storm, Arie, 217

Streng, Toos, 24

Sturkenboom, Dorothée, 111, 112

Stuurman, Siep, 20

Stynen, Ludo, 23

Sulis, Giglioa, 32 
Swelheim-de Boer, Reinsk, 90

Swinnen, Aagje, 29, 152

Swire, Otta F., 179

Tacitus, 17

Tartt, Donna, 14

Taverne, Ed, 107, 109

Taylor, Charles, 73, 184, 216

Tielman, Rob A.P., 60

Timmermans, Felix, 218

Tomkins, Silvan, 159, 160, 161, 170

Tompkins, Jane, 8

Uphoff, Manon, 217

Vaessens, Thomas, 9, 10

Vall, Renée van de, 198

Varma, Devendra P., 92

Vasari, Giorgio, 16, 19

Veeder, William, 125

Velde, Th.H. van de, 192

Ver Huell, Alexander, 23

Verbij, Antoine, 172

Verbogt, Thomas, 108, 132

Verhoeven, Paul, 70

Verhoeven, W.M., 105

Verlooy, 19

Vermeer, Leonieke, 8

Verschoore, N., 68

Verstappen, J., 68

Versteegen, Jos, 41

Verstraten, Ronald, 93

Vervaeck, Bart, 40, 41, 58, 155, 203

Vestdijk, Simon, 68, 217, 218

Vincent, Sybil Korff, 78

Vink, R., 187

Visser, Ab, 32

Vogelaar, Jacques, 217

Vooren, Rob, 68, 69

Vries, J. de, 24

Vries, Marleen de, 26

Vulpius, C.A., 24

Wagener, S.C., 26

Walker, Kenneth, 192
Walker, Richard J., 32

Wallace, Diana, 29

Walpole, Horace, 13, 18, 24, 37, 54, 104

Warmerdam, Hans, 132

Warren, Hans, 11, 42, 43, 132, 169, 218

Warwick, Alexandra, 180

Watt, Ian, 142

Waugh, Patricia, 94

Webeling, Pieter, 141

Weber, Max, 184

Weber, Veit, 24

Webster, John, 53

Weegh, Arne op de, 35, 40, 41, 44, 45, 47

Weeks, Jeffrey, 60, 61

Weijers, Ido, 72

Weisgerber, Jean, 218

Weldon, Fay, 80

Wesseling, Lies, 7, 8, 11, 12, 15, 21, 26, 27, 71, 72, 73, 104, 140, 141

West, Russell, 112

Wester, Rudi, 141

Westerman Holstijn, A.J., 90

Wieringa, Saskia, 9, 167

Wilde, Oscar, 56

Williams, Ann, 14

Winnett, Susan, 99

Wit, J.S.J. de, 187

Wolff, Betje, 24

Wolff, Cynthia, 29

Wolfgang, Aurora, 166

Wolfreys, Julian, 78

Wolkers, Jan, 10, 62, 68, 218

Woolf, Virginia, 145

Wright, Angela, 16, 184

Zetternam, Eugeen, 23

Zlosnik, Sue, 29, 32, 49, 78, 79, 80, 81, $87,88,92,123$

Zonneveld, Peter van, 25

Zschokke, H., 24

Zuidinga, Robert-Henk, 27, 32, 140, 218 


\section{CURRICULUM VITAE}

Agnes Andeweg (Zwolle, 1971) deed in 1989 eindexamen Gymnasium B aan het Carolus Clusius College te Zwolle. Aan de Landbouwuniversiteit Wageningen studeerde zij enige tijd Milieuhygiëne; zij haalde daar in augustus 1990 het propedeusediploma. Vanaf februari 1991 studeerde zij Nederlandse taal- en letterkunde aan de Universiteit Utrecht. Ze specialiseerde zich in Literatuurwetenschap en Vrouwenstudies en studeerde in 1995 af met een scriptie over de poëzie van Elly de Waard. Na haar afstuderen werkte ze als free lance redacteur voor uitgevers en als literair recensent voor o.a. Vrij Nederland, Roodkoper en Trouw. Daarnaast werkte ze als docent bij de Universiteit Utrecht en in organisatorische functies bij de Universiteit voor Humanistiek. Ze was jarenlang redacteur van het Tijdschrift voor Genderstudies. Het promotieonderzoek voerde zij uit bij het Centrum voor Gender en Diversiteit van de Universiteit Maastricht. Sinds 2002 doceert ze bovendien aan het University College Maastricht. 